\title{
HAGYOMÁNYOK ÉS KIHÍVÁSOK V. MÚLT ÉS JöVÖ
}

ORSZÁGOS KÖNYVTÁRSZAKMAI NAP, 2016 



\title{
HAGYOMÁNYOK ÉS KIHÍVÁSOK V. MÚLT ÉS JÖVŐ
}

\section{ORSZÁGOS KöNYVTÁRSZAKMAI NAP, 2016}

\author{
Szerkesztette: \\ Szabó Panna és Székelyné Török Tünde
}

ELTE Egyetemi Könyvtár és Levéltár Budapest, 2017 
Hagyományok és kihívások V. Múlt és jövő

Országos Könyvtárszakmai Nap, 2016

Szerkesztette:

Szabó Panna és Székelyné Török Tünde

A tanulmányokat lektorálta:

Muzeális gyüjtemények szekció: Knapp Éva

Irányok, eredmények a hazai egyetemi könyvtárügyben, valamint a Komplex

adatbázis-keresők szekció: Barátné Hajdu Ágnes, Csík Tibor, Fodor János, Kerekes Pál, Kosztyánné Mátrai Rita, Németh Katalin, Senkei-Kis Zoltán

A 2016. augusztus 31-én rendezett konferencia az Egyetemi Könyvtárért Alapítvány támogatásával valósult meg.

ISBN 978-963-284-875-4

DOI: https://doi.org/10.21862/HagyKihiv_2016

C A szerzők és a szerkesztők, 2017

Az absztraktokat fordította: Széles Ágnes

A kötet elektronikus formában elérhető az ELTE repozitóriumában: https://edit.elte.hu

Kiadta az ELTE Egyetemi Könyvtár és Levéltár

Felelős vezető: Kálóczi Katalin

1053 Budapest, Ferenciek tere 6 .

http://konyvtar.elte.hu
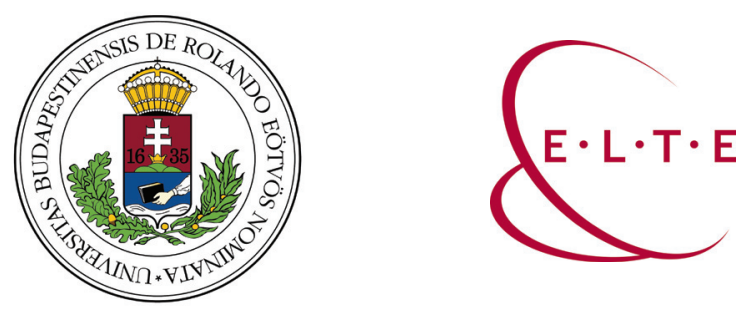


\section{Tartalom}

KÁLÓCZI KATALIN: Köszöntő a Hagyományok és kihívások rendezvénysorozat áttekinése tükrében ........................................................................................ 7

SZALAY PÉTER: A könyvtárak az ELTE stratégiai céljai szolgálatában .................... 11

\section{Irányok, eredmények a hazai egyetemi könyvtárügyben}

KISZL PÉTER: Az IFLA stratégiai célkitüzései - hazai és nemzetközi könyvtári párhuzamok

GARAMVÖLGYI LÁSZLÓ: Hogyan csapjuk az online szelet az Y generáció számára? ... 37

CZINKI-VIETORISZ GABRIELlA: Dezideráta szolgáltatás bevezetése az ELTE Egyetemi Könyvtárban

CSUK CSABA: Tanulástámogató szolgáltatások a Savaria Egyetemi Központ Könyvtárában 55

KNAPP ÉVA: Az ELTE Egyetemi Könyvtár ősnyomtatványtára 69

\section{Muzeális gyűjtemények}

CSÉKA GYÖRGY: Rejtett vizuális értékek: 19. századi és modern fotográfiák az ELTE Egyetemi Könyvtárban.............................................................. 91

TÜSKÉS ANNA: Pauler Tivadar jogi szakkönyvtárának 1872-es katalógusa............. 99

MÁtYÁs MelindA: A Hevenesi-, Kaprinai-, Pray-kéziratgyűjtemény feldolgozásának kérdései.

DOMOKOs GYÖRGY: A ELTE Egyetemi Könyvtár Vergerio-grammatikája (Cod. Lat. 23) 121

GyuriczA ANDreA: A Nemzeti Casino 


\section{Komplex adatbázis-keresők}

NASZÁDOS EDIT: Könyvtárak - belépési pontok a digitális világba ..................... 149

BÖRZSÖNYI NÓRA: A Szuperkereső felemelkedése: EDS a Corvinuson ................... 159

HAÁSz ANTAL: A Primo használata a Magyar Tudományos Akadémia Könyvtár és Információs Központban .

VIRÁG GABRIELLA: OPAC 2.0 az ELTE-n: Webkettes technológiákra épülő VuFind könyvtári keresőszoftver

Kötetünk szerzői 


\section{Köszöntő a Hagyományok és kihívások rendezvénysorozat áttekintése tükrében}

Kedves Vendégeink, tisztelt Résztvevők!

Az ELTE Egyetemi Könyvtár vezetőjeként magam és munkatársaim, az Egyetemi Könyvtár könyvtárosainak nevében szeretettel köszöntöm Önöket a 2016ban ötödik alkalommal megrendezett Hagyományok és kihívások címü szakmai konferenciánkon.

2011-ben, öt évvel ezelőtt indult ez a ma már rendezvénysorozatnak tekinthető konferencia, amelyen az Egyetemi Könyvtár munkatársai a világ elé, azaz a szakmai közönség elé állnak. Előadásaink célja, hogy bemutassuk azokat a fejlesztéseket és mühelymunkákat, amely az Egyetemi Könyvtár falain belül folynak, és amelyek remélhetőleg egyre szélesebb körben ismertté válnak.

Engedjék meg, hogy röviden áttekintsem eddigi rendezvényeink fontosabb témaköreit, eredményeit. Több előadó és előadás foglalkozott a már korábban megkezdett minőségfejlesztési programunk ismertetésével: bemutatásra kerültek a partneri igény- és elégedettségi mérések eredményei, a folyamatmenedzsment meghatározó tényezői, első önértékelésünk módszertana és konklúziói, valamint a minőségfejlesztési programmal párhuzamosan zajló szervezeti átalakulás kérdései, a munkamódszereink megváltozásának mozzanatai.

Az Egyetemi Könyvtári Szolgálatban (amely az ELTE könyvtárainak közössége, együttmüködése) kialakult új munkamegosztás is több szempontból tárgyalásra került.

- Közös feladatunk a minőségfejlesztésen túl a könyvtárosok felkészítése a közösen megfogalmazott célok elérésére. Az e téren tett erőfeszítéseinkről részletesen számot adtunk a kulturális szakemberek képzésére elnyert TÁMOP-pályázatunk lezárása után.

- A könyvtári rendszer az ELTE felhő szolgáltatásainak ernyője alá került, amely számos fejlesztésre adott lehetőséget.

- Az Egyetem könyvtárai új portálon, közösen jelennek meg.

- Forradalmi változás volt, hogy a korábbi felsőoktatási integráció örökségét, a széttagoltan müködő elektronikus katalógusokat közös adatbázisba szervezetük, több százezer rekordot migráltunk, javítottunk. A közös katalogizálás maga után vont számos megoldandó problémát, feladatot: több előadás foglalkozott a rekordok minőségével, a soknyelvü állomány, ezen belül a nem latin ábécét használó nyelvek dokumentumainak feltá- 
rásával, az időszaki kiadványok egységes kezelésével és feldolgozásával, az együttmüködés és az országos adatbázisoknak (például a Magyar Országos Közös Katalógusnak) való rekordátadás problémáival.

- A portál és az integrált könyvtári rendszer egyesítése szintén TÁMOP pályázati támogatással valósult meg.

- Kitértünk a szakmai közvéleményt foglalkoztató aktuális témákra, például a digitalizálás, a digitális tartalmak kezelésének kérdéskörére.

- Bemutattuk a muzeális értékü és nagy jelentőségü, mintegy 1,2 millió cédulát tartalmazó Alapkatalógusunk digitalizálását. A katalógus a portálunkról elérhető, kereshető, és első lépése volt több részből álló katalógusrendszerünk online közzétételének.

- Digitalizáltuk és feltártuk a több mint 12000 tételből álló metszetgyüjteményünket.

- Szintén több elöadásban foglalkoztunk az intézményi repozitórium, az EDIT (ELTE Digitális Intézményi Tudástár) kialakításával, fejlesztésének kérdéseivel.

- Rendezvényeink során képet kaphattak arról, hogyan kapcsolódtunk be a kutatók számára kiemelten fontos MTMT (Magyar Tudományos Múvek Tára) építésének munkálataiba.

- A könyvtárhasználók számára fejlesztett új szolgáltatásainkat is bemutattuk, amelyek közül kiemelném az online katalógusban keresett dokumentumok távoli kikérésének kialakítását.

Konferenciánkon a belső mühelymunka problémái, eredményei mellett természetesen mindig helyet kapott a történeti állomány bemutatását, illetve annak hagyományos kezelését illusztráló tudományos igényű előadás is. Azonban remélem, érzékelhető, hogy ezen a területen is szemléletet váltottunk: míg korábban a saját munkatársaink állományon végzett kutatásai álltak a középpontban, addig ma az állomány minél teljesebb, korszerübb feltárása, hozzáférhetővé és kutathatóvá tétele kerül tevékenységünk középpontjába.

Meghívott előadóink között rendszeresen szerepel a Könyvtár- és Információtudományi Intézet igazgatója, valamint kollégái, illetve az egyetem különböző szervezeti egységeinek munkatársai is, akikkel közös projekteket valósítottunk - valósítunk meg. Ez is jól mutatja, hogy az egyetem oktatási és igazgatási szervezeti egységeivel számos területen alakult ki szakmai együttmüködés, s a jó gyakorlatok széleskörủ megosztása hozzájárul a színvonalas munkavégzéshez.

Számomra, mint az intézmény felelős vezetője számára kiemelendő eredmény, hogy munkatársaim egyre nagyobb számban vállalják, hogy a nagyközönség előtt is bemutassák munkájukat, szakterületük eredményeit. Az eddigi négy konferencián tizenhárom kolléga huszonnégy előadást tartott. E rendezvényeknek is köszönhetően emelkedik a szakmai publikációk, valamint a hazai és 
a nemzetközi könyvtártudományi rendezvényekre szóló meghívásaink száma. Számos könyvtár kér tőlünk konzultációt szakmai megoldásaink megmutatására. Konferenciánkon évről évre növekedett az érdeklődők száma, és megjelent az igény, hogy kötetbe is rendezzük előadásainkat. A Hagyományok és kihívások címü rendezvényünk eredményei bizonyítják, hogy az Egyetemi Könyvtár az utóbbi években nyitottabb, befogadóbb intézménnyé vált, és ma már nem csupán hagyományai, állományának nagysága és muzeális kincsei, hanem a szakmai munka minősége okán is a magyar könyvtári rendszer egyik alappillére.

Hölgyeim és Uraim, kedves Vendégeink!

Nagy megtiszteltetés számunkra, hogy itt vannak. Köszöntöm és üdvözlöm az ágazati irányítás képviselőit, az egyetem vezetésének delegáltjait, a társszervezetek és a szakmai intézmények - egyetemi, oktatási szféra és az egyházi könyvtárak - képviselöit. Valamint itt köszönthetem számos régi és fiatalabb kollégámat is, az egyetem könyvtárosait. Köszönöm, hogy itt vannak, és alkalmunk nyílik arra, hogy a programban kitűzött szakmai beszélgetések során Önökkel közösen gondolkodjunk arról, mit és hogyan tehet a könyvtáros szakma a hazai kultúra és a felsőoktatás eredményesebb müködéséért.

KÁLÓCZI KATALIN föigazgató ELTE Eötvös Loránd Tudományegyetem Egyetemi Könyvtár 



\section{A könyvtárak az ELTE stratégiai céljai szolgálatában}

\section{Tisztelt Főigazgató Asszony, kedves Kollégák!}

Megtisztelő számomra, hogy beszélhetek Önöknek arról, hogy az elkövetkező években milyen szerepet szán az egyetem vezetése az intézmény könyvtárainak tervezett fejlesztésére. Különösen érdekes számomra ebben a csodálatos teremben beszélni, ahol egyetemistaként oly sok időt eltöltöttem tanulással. Noha fizikai értelemben ma már sokkal kevesebbet járunk könyvtárba, mint annak idején, a könyvtár bővülö, átalakuló szolgáltatásai ma is nélkülözhetetlenek a tudósok és tanárok számára.

Ez év tavaszán készült el az egyetem 2016-2020 közötti periódusra vonatkozó Intézményfejlesztési Terve, az IFT. Több szempontból is különbözik ez a dokumentum a korábbiaktól: egyrészt a fenntartó világossá tette, hogy nemhogy fejlesztési pénzek, de még nagyobb pályázatok sem nyerhetők el, ha nincsenek összhangban az IFT-vel. Másrészt tavaly ősszel Rektor úr és Kancellár úr kezdeményezésére soklépcsős folyamat indult el annak érdekében, hogy kialakítsuk az egyetem hosszú távú vízióját, megfogalmazzuk értékeit, szerepét Magyarországon, a régióban és Európában. Ez a gondolkodás rányomta bélyegét a rövidebb távú tervezésre is. Véleményem szerint a korábbiaknál lényegesen használhatóbb dokumentum született.

Melyek is a leglényegesebb sarokkövek? Stratégiai cél, hogy az ELTE az európai mezőny meghatározó kutatóegyeteme legyen, vonzó környezetet biztosítva az oktatáshoz, kutatáshoz, valamint a hazai és a közép-európai régió egyik vezető egyetemi központjaként versenyképes diplomát nyújtson az itt végzett hallgatók számára. Azonban a hagyományokat megtartva továbbra is kiemelt feladatunknak tekintjük a nemzeti és az egyetemes kultúra és műveltség megőrzését és gyarapítását. Első olvasásra úgy tủnhet, hogy az IFT kifejtésébe kevés konkrétum került az Egyetemi Könyvtári Szolgálatról (EKSZ). Nézzük meg azonban egy kicsit jobban! Az IFT-ben lefektetett fő stratégiai irányok a következők:

- új, átfogó kiválósági program kidolgozása és elindítása a szakkollégiumok bázisán;

- a kiválóság erősítése a kutatás terén és a $\mathrm{K}+\mathrm{F}+\mathrm{I}$ lánc hiányzó elemeinek fejlesztése;

- a képzés hatékonyabb, fókuszáltabb nemzetköziesítése;

- az egyetem teljesítményének szisztematikus monitorozása, továbbá az oktatók teljesítményelvủ értékelésének megvalósítása. 
E négy cél melyike valósítható meg modernizált könyvtár nélkül? Egyik sem, hiszen a könyvtár szerepe mindegyikben megkerülhetetlen. A tehetséggondozás és a Kutatás - Fejlesztés - Innováció modern szakirodalom nélkül elképzelhetetlen. A hatékony oktatás új módszereket igényel, melyhez digitális eszközökben, tananyagokban a könyvtárosokra is számítunk. A nemzetköziesítéshez az idegen nyelvü könyvek és más információhordozók beszerzése szükséges, továbbá az egyetem teljesítményének monitorozása elképzelhetetlen adatbázisok nélkül, melynek legfontosabb ismeröi éppen a könyvtárosok. Éppen ezért az IFT megszületése után Könyvtári Stratégia született és kezdi meg göröngyös útját az egyetem döntéshozatali hierarchiájában. Ez a stratégia a Főigazgató asszony keze alatt az Önök segítségével készült. Az egyetem vezetése nevében köszönöm ezt a munkát. Melyek e stratégia legfontosabb pillérei, és hogyan szolgálják az egyetem céljainak megvalósulását?

\section{Legyen a könyvtár az ELTE tartalomszolgáltató tudásközpontja}

Az egyetem története, müködése során keletkezett, felhalmozott írott és tárgyi szellemi vagyont össze kell gyüjteni, archiválni kell és be kell mutatni a nagyközönségnek. Ennek érdekében ki kell alakítani a digitális egyetemi közgyüjteményt: e-tananyagok, e-tartalmak, az egyetem tárgyi és szellemi tudásvagyonának - mint például könyvtári, levéltári, muzeális dokumentumok, tárgyak, események, unikális gyüjtemények, publikációk, tudományos dolgozatok - digitalizálásával, felkutatásával, adatbázisban való feltárásával és közzétételével. A müködtetéshez ki kell dolgozni a szükséges szerzői jogi és közzétételi szabályozást is.

Tudásközpont: gyakran használt fogalom mostanában, de itt a helyén van. Tudást tárol, de egyben az itt dolgozók révén itt van e tudásvagyonnal való bánás tudománya is. Ezzel kell, hogy segítse a kutatást és az oktatást.

\section{Legyen a könyvtár az egyetem tudományos müködésének és tevékenysé- gének támogatója}

Sajnos, vagy nem sajnos, a teljesítményt minden szinten mérni kell, bármennyire legyen is absztrakt a produktum. Ebben is nagy szerepe van a könyvtárnak.

Az oktatói, kutatói teljesítményt mind bibliográfiai szinten, mind teljes szöveggel a lehető legmélyebb merítéssel be kell mutatni, mérhetővé kell tenni. Ezekkel támogatni kell a hazai és a nemzetközi kutatási együttmüködéseket, a tudományos és az intézményi minősítéseket, a minőségbiztosítást, az akkreditációt és a tudományos tevékenységeket, vagy éppen az IFT teljesülését. Ehhez meg kell erősíteni például az MTMT, az EDIT és a Stratégiai Adatbázis adminisztrátori hálózatát, és biztosítani kell a szükséges kompetenciákkal rendelkező emberi erőforrást. 
A kutató és oktató munkához be kell szerezni a szükséges adatbázisokat, támogatni és erősíteni kell az open access publikálást.

Mindezek erősítésére konzultációt és képzést kell szervezni az oktatók és az adminisztrátori hálózatban dolgozó munkatársak számára. Az oktatók képzése - ellenállásuk miatt - sok esetben nehéz dió lehet, mégis kérem, ebben is segítsenek minket türelemmel és megértéssel!

\section{Legyen a könyvtár tanulási központ és közösségi tér}

Már a bevezetésben említettem, milyen élmények füznek ehhez a teremhez. Meggyőződésem, hogy a könyvtár közösségi térként a digitális világban is megmaradhat, ha megtaláljuk a megfelelö funkciókat.

Olyan felhasználó-központú, felhasználóbarát szolgáltatásokat szükséges fejleszteni, amelyek az igényekhez jobban illeszkednek, a tanulást és a tanulás új formáit támogatják. A nyújtott szolgáltatásokhoz, az állományhoz és a dokumentumokhoz való teljesebb, gyorsabb, akadálymentes, korszerü felületeken és eszközökkel való hozzáférést kell biztosítani.

Ennek érdekében létre kell hozni a tanulást támogató fizikai és virtuális tereket, technikai és technológiai fejlesztésekkel a könyvtárt mint lehetséges közösségi teret be kell vezetni a használatba. A használói célcsoportok elégedettségét és igényeit folyamatosan mérni, elemezni és az eredményeket hasznosítani kell. Olyan „,egykapus” keresőfelületet, online idegen nyelvü szolgáltatási platformot kell 7/24 eléréssel biztosítani, amely az egyetemi partnerszervezetekkel közös fejlesztésekben születnek.

Egy apró példa az új funkciókra: Főigazgató Asszony segítségével itt tartottuk az egyetem Tudományos Napját, ahol többek között átadtuk az ELTE Ígéretes Kutatója elismerést. Azt hiszem, ennél méltóbb helye ennek a rendezvények nem lehet. Idén is ide tervezzük az ünnepséget.

\section{Legyen a könyvtár hatékonyan müködő szervezet}

Az ELTE sokszínủ egyetem. Ennek megfelelően könyvtárai is sokszínủek, nagyon különböző elvárásoknak kell megfelelniük. De a szolgáltatások színvonala egységes kell legyen, és a fejlesztéseket is célszerübb egységesen megvalósítani.

A felelösség, hatáskör és a feladatok újradefiniálása az EKSZ tagkönyvtárai (és az esetlegesen további bevonandó szervezeti egységek, közgyüjtemények) közötti belső munkamegosztást, az erőforrások jobb kihasználását, a szervezet hatékonyabb müködését kell, hogy eredményezze. Az Egyetemi Könyvtár által központilag nyújtott szolgáltatások és kibővített központosított feladatvégzés, a szolgáltatói attitüd erősítése eredményezi a kari és szervezeti egységek könyvtárainak hatékonyabb együttműködését, a helyi oktatási, kutatási igényeknek megfelelőbb szolgáltatások nyújtását. A kialakított központi szolgáltatások és a szakmai 
feladatok megosztása - például igény szerint központi beszerzés, feldolgozás, állományrevízió - lehetővé tennék az EKSZ tagkönyvtárak helyi szolgáltatásainak bővítését, minőségük emelését.

Az EKSZ mint több területen is együttmüködő szervezet rendelkezhet megfelelő humánpolitikai stratégiával, és alkalmas a magas kompetenciájú munkatársak bevonzására, megtartására. A humánstratégia központi elemeként fel kell mérni a hiányzó kompetenciákat, ki kell alakítani a szervezet és a munkatársak igényeihez igazított képzési tervet, be kell vezetni a teljesítményértékelést, a tudás és teljesítmény elismerésére irányuló rendszert, valamint ki kell alakítani az életpályamodellt. Mindezek következtében az EKSZ könyvtárainak és könyvtárosainak elismerése növekszik, amely megalapozhatja az átfogó stratégiai cél megvalósítását.

\section{Finanszírozás}

A célok egy része megvalósítható a meglévő anyagi erőforrások felülvizsgálatával, átcsoportosításával, a szervezet hatékonyságát növelő intézkedések megtételével, új feladatmegosztással, a belső erőforrások átcsoportosításával, az EKSZ erősségeinek kiaknázásával.

A stratégiai célokat, a szolgáltatások színvonalának emelését pályázati források bevonásával, az Egyetemi Könyvtárért Alapítvány támogatásával, a digitális közmunkaprogram lehetőségeinek kiaknázásával, a feladatok átszervezésével, és nem utolsó sorban a már korábban említett elkötelezett, lojális, megfelelően bérezett munkatársakra támaszkodva hatékonyabban lehet megvalósítani.

Az egyetem vezetésének azonban nincsenek illúziói: a jobbhoz ennél is több forrásra lesz szükség. Az információs, illetve tudástársadalomban az információ, a digitális tartalmak kezelése, az új szolgáltatások, a fejlesztések központi kezelést, irányítást, ennek következtében kiszámítható és elégséges büdzsét igényelnek.

A büdzsé kialakításának első sarkalatos pontja a teljes egyetem számára nyújtandó szolgáltatások, könyvtári/közgyüjteményi tevékenységek és müködés egyetemi infrastruktúraként való újradefiniálása. Ez maga után vonja, hogy a könyvtárakra, illetve az oktatást és kutatást támogató könyvtárakhoz kapcsolható egyes tevékenységekre fordítandó költségeket el kell különíteni. Ugyanígy a forrásokat: ebbe nem csupán az állami támogatást, de a kutatási pályázatok meghatározott részét is ide kell sorolni. A kutatási és oktatásfejlesztési pályázatok esetében is figyelembe kell venni a könyvtári információs szolgáltatásokhoz kapcsolódó IT fejlesztéseket, szoftver- és licencebeszerzéseket. A büdzsé tervezésekor kiemelt fontosságú többek között az idegen nyelvű szakirodalom, a folyóiratok, az adatbázisok beszerzése, valamint a publikációs tevékenység garantált és az igényeknek megfelelő támogatása, különös tekintettel az open accessre.

Az egyetem vezetése elkötelezett a könyvtári szolgáltatások fejlesztése mellett, hiszen tisztában vagyunk azzal, hogy a fejlesztési tervében leírt célok eléréséhez 
a könyvtárra, könyvárakra is szükség van. Lelkiismeretes munkájuk mellett már csak türelmet kell kérjek, hiszen az olyan változások, mint például a finanszírozás kapcsán említett átcsoportosítás, csak lassan valósíthatók meg. De már megtettük az első lépést: az EISZ önrészt központi forrásból fizette tavaly az egyetem, és idén is így készült a költségvetés.

A konferencia programjának alapján az elmondottak sok aspektusa kerül majd megvitatásra, tehát a rendezvény az ELTE könyvtári rendszere megújulásának is fontos lépése. Ezért aztán szívből kívánok Önöknek jó munkát és - tudományról és művészetről lévén szó - kellemes időtöltést.

SZALAY PÉTER

tudományos ügyek rektorhelyettese ELTE Eötvös Loránd Tudományegyetem ORCID: 0000-0003-1885-3557 



\section{IRÁNYOK, EREDMÉNYEK}

A HAZAI EGYETEMI KÖNYVTÁRÜGYBEN 



\section{Az IFLA stratégiai célkitüzései - hazai és nemzetközi könyvtári párhuzamok}

\section{Könyvtár és más}

„Napjainkban a könyvtárak - társadalmi, gazdasági és környezetvédelmi problémákból fakadó - alkalmazkodóképességének, szerepbövülésének fokozása a legnagyobb kihivás. A könyvtár a közösség iránt elkötelezett intézményként élénk és kiterjedt kapcsolatot ápol kormányzati és más szervezetekkel, életünk megannyi szereplöjével, és jelentősen túlhaladja klasszikus dokumentum- és információszolgáltató küldetését. A könyvtár - mint multifunkciós intézmény - vitathatatlanul paradigmaváltáson ment keresztül az információs társadalom korában. Célrendszere komplex feladatkörü és mozgalmas, az állampolgárok minden rétegével napi kapcsolatban áll, az emberekkel ,együtt lélegző” közintézmény”l - állapítottuk meg az Amerikai Könyvtári Egyesület (American Library Association = ALA) 2014-es jelentését ${ }^{2}$ értékelve korábbi tanulmányunkban.

A fenti gondolatokat ma, 2016 öszén is egyértelmüen megerősíthetjük. A könyvtár tradicionálisan értéket közvetít, eligazít az információk tömkelegében, vagy akár információhiány esetén siet segítségünkre. A könyvtár kipróbált, évezredes kultúra- és tudásközvetítő intézmény. De hol vannak már a láncos könyvek és azok a gyüjtemények, ahol a légy zümmögését is hallani? A mai könyvtárakban enni-inni, relaxálni, kutyát simogatni vagy táncolni (1. ábra) is lehet. Napjaink könyvtára nem „,csak” a dokumentumok őrzője, információszolgáltató intézmény, hanem pezsgő közösségi tér, rendezvényektől nyüzsgő tudásvár és szociális bázis. A könyvtár küzd a társadalmi egyenlőtlenségek mérsékléséért, annak érdekében, hogy az ismeretek mindenkihez eljussanak. A könyvtár - elektronikus szolgáltatásai, katalógusai és teljes szövegü állományai révén - 0-tól 24 óráig a használók rendelkezésére áll virtuálisan és esetenként fizikailag is. A könyvtár nem kizárólag a négy fal között létezik, strandon vagy buszon, hajón vagy tevén egyaránt. A könyvtár elősegíti a fenntarthatóságot, az esélyegyenlőséget, a társadalmi kohéziót. A könyvtári fejlesztések felelősei számára épp ezért létkérdés a környezeti tényezöket szünet nélkül monitorozni, azok hatásaival számolni, ellenkező esetben a szektor minden tekintetben - legfőképp persze a közmüvelödés, illetve a kultúra rendszerében - súlyos versenyhátrányba kerülhet.

${ }^{1}$ Kiszl Péter: Könyvtárak a közösségért - New Yorkban. = Tudományos és Műszaki Tájékoztatás, 61. évf. 2014.9. sz. 315. p. http://tmt.omikk.bme.hu/show_news.html?id=5941\&issue_id=563

2 The State of America's Libraries Report 2014. A report from American Librarian Associaton. $=$ American Libraries. Special issue. 81 p. http://www.americanlibrariesmagazine.org/issue/ state-americas-libraries-2014 (2016. október 25.)

https://doi.org/10.21862/HagyKihiv_2016.19 


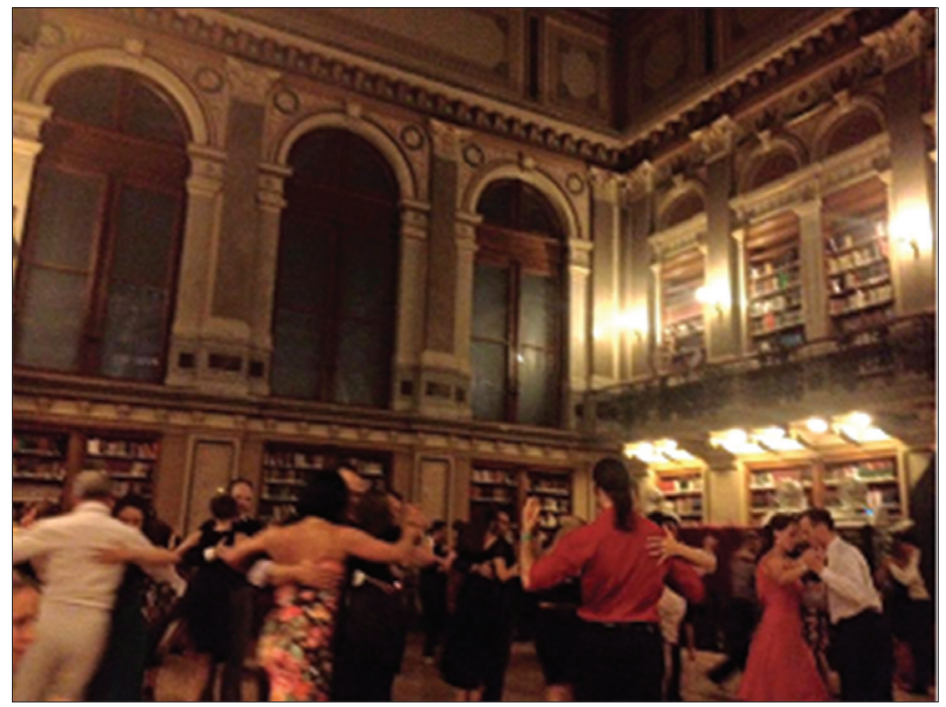

1. ábra. Tangóest az ELTE Egyetemi Könyvtár dísztermében³

\section{Könyvtárak és stratégia}

A könyvtárak világa tehát gyökeresen átalakult, az új elvárások új szolgáltatásokat igényelnek. ${ }^{4}$ Mindez nem valósítható meg átgondolt, a szakmai szervezetektől az állami ágazati irányításig, majd az intézmények szintjéig terjedő stratégiai tervezés nélkül. Tanulmányunkban a legjelentősebb nemzetközi könyvtári ernyőszervezet, ${ }^{5}$ az IFLA (International Federation of Library Associations and

${ }^{3}$ Forrás: https://www.facebook.com/ELTEkonyvtar (Isabella León bejegyzése alapján, 2016. augusztus 27.)

${ }^{4}$ A dolgozatnak nem célja a könyvtár elnevezésről és kapcsolódó szakmai álláspontokról értekezni, bár a terminológia nem közvetíti teljes mértékben az intézményhálózat jelentősen kiszélesedett szerepét, azonban továbbra is ennek alkalmazását tartjuk kívánatosnak. Nyomós érvként hozhatjuk, hogy jobb megnevezést még nem sikerült megalkotni, $\mathrm{s}$ az egész világon, a társadalom minden rétege tradicionálisan ismeri, egyértelmủen képes beazonosítani a megjelölés mögötti közgyűjteményi alapszolgáltatásokat. A gyakorlatban leginkább elterjedt kiegészítés az intézménynevekben a könyvtár mellé feltüntetett információs központ. Két hazai példa: Budapesti Müszaki és Gazdaságtudományi Egyetem Országos Müszaki Információs Központ és Könyvtár, Magyar Tudományos Akadémia Könyvtár és Információs Központ. Ennek analógiájára vö.: Koltay Tibor - Prókai Margit: Terminológiai változások a XX-XXI. századi könyvtártudományban. = Magyar Terminológia, 3. évf. 2010. 2. sz. 269-283. p.

5 „The International Federation of Library Associations and Institutions (IFLA) is the leading international body representing the interests of library and information services and their users. IFLA is an independent, non-governmental, not-for-profit organization with over 1300 members in nearly 140 countries. We work to improve access to information and cultural heritage resources for the global community in this rapidly changing digital and print environment. Our key initiatives include access to digital content, international leadership, outreach, cultural heritage, and multilingualism. In our professional programmes we build the capacity of our members, and set the professional agenda 
Institutions $=$ Könyvtári Egyesületek és Szervezetek Nemzetközi Szövetsége) célkitüzéseit és kapcsolódó dokumentumait elemezzük - terjedelmi korlátok miatt erőteljesen válogatva, a föbb elemeket kiemelve - a hazai adaptáció elösegítésének szándékával. Mielőtt azonban erre rátérnénk, szükséges röviden meghatározzuk a stratégiai tervezés ${ }^{6}$ kapcsán mindenképpen továbbgondolásra javasolt, akár önálló dolgozatok témájául is szolgáló sarokpontokat:

a) Önvizsgálat: hogyan definiáljuk ma a (modern) könyvtárat? Könyvtári dokumentumok tervszerüen gyarapított (és apasztott), rendezett és feltárt, megőrzésre és használatra szánt gyüjteménye - a mindannyiunk által jól ismert definíció már csak az alapfunkciót jelöli ki. ${ }^{7}$ Ezzel párhuzamosan érdemes azt is számításba venni, hogy az infokommunikációs fejlődés egyszerre lehetőség és kihívás ${ }^{8}$ a bibliotékák számára.

b) „Csak a változás állandó” - környezeti tényezőkhöz és prognózisokhoz, ágazati stratégiákhoz való állandó igazodás.

c) Célok kijelölése a realitások (és források) mentén.

d) Naprakész szakértelem, élethosszig tartó tanulás. ${ }^{10}$

e) Rendelkezésre állás a nap 24 órájában, a hét 7 napján, mindenki számára hozzáférhetően.

f) További jellemzők a teljesség igénye nélkül: proaktivitás, folyamatos alkalmazkodás és innováció, kommunikáció és együttmüködés, jó gyakorlatok követése, rendszerszemlélet és feladatmegosztás, differenciálódás, visszacsatolás és korrekció stb.

A következőkben - orientáló jelleggel - felsoroljuk azokat az IFLA-hoz kötődő kiindulópontokat (dokumentumokat és internetes forrásokat), melyek tanulmányozása segítheti szakmai fejlődésünket.

through development of guidelines, standards, publications and events around the world. IFLA's status as the global organisation for library and information services ensures that our voice is represented through formal relations with the UN and other organisations." Forrás: IFLA Trend Report 2016 Update 2. p. http://trends.ifla.org/files/trends/assets/trend-report-2016-update.pdf (2016. október 25.)

${ }^{6}$ A stratégiai tervezés jelentőségére találóan rámutat az IFLA Trend Report 2016 Update mottója is: „, It is far better to foresee even without certainty than not to foresee at all." (Jules Henri Poincaré, The Foundations of Science, 1913.)

${ }^{7}$ A modern (köz)könyvtár alapfunkciót a következökben határozhatjuk meg: (1) dokumentumközpontú, ingyenes alapszolgáltatások; (2) (jelentős) hozzáadott értékkel bíró, információközpontú szolgáltatások; (3) kulturális örökség megőrzése, átörökítése, archiválása; (4) közösségi tér; (5) szociális szerep; (6) kiegészítő szolgáltatások. Ld.: Kiszl Péter: i. m. 316. p.

${ }^{8}$ Gondoljunk csak például a Google és a közösségi alkalmazások térhódítására a mindennapi informálódásban, vagy az elektronikus dokumentumok sokszínű előfordulásaiból, változásaiból és egyéb jellemzőiből származó archiválási, feltárási problémákra, de leginkább az információbőség vs. információínség kérdéskörére, illetve a mennyiség - minőség - időtényezö összefüggéseire.

${ }^{9}$ Herakleitosznak tulajdonított bölcsesség.

${ }^{10}$ Az oktatás (,good education”) világszerte kiemelt jelentőségét támasztja alá toronymagas elsőbbségével: MY World Analytics. United Nations: http://data.myworld2015.org (2016. október 25.) 


\section{Hol tart a világ 25 év múlva?}

Ian Goldin, az Oxfordi Egyetem professzora ${ }^{11} 2016$ májusában, az EBRD (European Bank for Reconstruction and Development = Európai Újjáépítési és Fejlesztési Bank) londoni konferenciáján ${ }^{12}$ meghatározta azokat a globális trendeket, melyek az elkövetkezendő negyedszázadban befolyással lesznek az emberiségre, ezáltal a könyvtárakra is:

a) A Földön 9,5 milliárd ember fog élni. Táplálásuk megoldható lesz, de az élelmiszerek összehasonlító áron a maiaknak a kétszeresébe kerülnek.

b) A globális GDP 80\%-a már a szolgáltatásokból származik.

c) A világgazdaság 2/3-át a ma fejlődőnek nevezett országok összterméke adja.

d) 3,5 milliárd középosztálybeli él majd a Földön, a legtöbben közülük Ázsiában.

e) Az USA vezető szerepe a fogyasztásban teljesen visszaszorul.

f) Kína, India, Amerika és Oroszország jelenlegi felsőoktatási kapacitásai - elsősorban demográfiai okok miatt - kihasználatlanok lesznek.

g) Sok, korábban szükösnek kikiáltott nyersanyagkészlet kapcsán derül ki, hogy még komoly tartalékok vannak, de a nem megújuló energiaforrások felhasználásának korlátozása a világpolitika legfontosabb feladatává válik.

h) Katasztrófához vezethet, ha nem csökkentjük a károsanyag-kibocsátást és a globális felmelegedést.

i) A leggyakoribb halálozási ok a levegőszennyezettséggel függ majd össze. ${ }^{13}$

\section{IFLA trendek 2013 és 2016}

Hosszas szakértői konzultációk eredményeképpen az IFLA 2013-ban, a Szingapúrban tartott éves világkongresszusán ${ }^{14}$ tette közzé az információs környezetet a jövőben várhatóan befolyásoló öt legfontosabb, általános érvényü tényezőt, illetve az e köré szervezett, nemzetközi könyvtárszakmai kommunikációra sarkalló honlapját:: ${ }^{15}$

1. Az információ-hozzáférés trendje: Az új technológiák egyszerre kiterjesztik, ugyanakkor korlátozzák is az információhoz való hozzáférést.

2. Az oktatás változásának trendje: Az online oktatás demokratizálja és fellazítja a hagyományos képzési formákat.

${ }^{11}$ Prof. Ian Goldin, Oxford Martin School, University of Oxford: http://www.oxfordmartin. ox.ac.uk/people/1 (2016. október 25.)

${ }^{12}$ European Bank for Reconstruction and Development (EBRD) Annual Meeting and Business Forum 11-12 May 2016, London: https://am2016.ebrd.com. Az előadás megtekinthető: https://www.youtube.com/watch?v=dvUWIwfSCBQ (2016. október 25.)

${ }^{13}$ Brückner Gergely: Szép új világ. = Figyelö, 59. évf. 2016. 30. sz. 59-62. p.

${ }^{14}$ IFLA World Library and Information Congress. 79th IFLA General Conference and Assembly. 17-23 August 2013, Singapore: http://www.ifla.org/past-wlic/2013/ifla79.htm (2016. október 25.)

${ }^{15}$ IFLA Trend Report: http://trends.ifla.org (2016. október 25.) 
3. A magáncélú adatokhoz kapcsolódó trend: A magánélet és az adatvédelem határai újradefiniálódnak.

4. A civil szférát erösitö trend: A világháló segítségével új közösségek alakulnak, akik egyre nagyobb szerephez jutnak.

5. A technológiai fejlödéssel összefüggö trend: Az új technológiák átalakítják a globális információs gazdaságot és az emberek mindennapi életét. ${ }^{16}$ A 14 nyelvre lefordított, a világ 30 országában, több mint 60 szakmai rendezvény keretében megvitatott trendjelentés és a kapcsolódó bibliográfia aktualizálására 2016-ban került sor. ${ }^{17}$ Ebből az európai szakembereket foglalkoztató kulcskérdések az alábbiak:

a) Új kihívások a szerzői jog, a tartalomhoz való hozzáférés és az e-kölcsönzés terén.

b) A magánélet megsértése az ellenőrzés eszköze vagy a felhatalmazás forrása?

c) Hogyan szüntethető meg a könyvtárosok közötti képzettségi különbség?

d) A könyvtárak stratégiai együttmüködésének erősítése.

e) A könyvtári szolgáltatások alapelvei, digitális lehetőségek és a felhasználói igények meghallgatása.

\section{IFLA stratégia 2016-2021}

Az IFLA legújabb, öt évre szóló stratégiai programját ${ }^{18} 2015$ decemberére alkotta meg a Barátné Hajdu Ágnes, a Magyar Könyvtárosok Egyesülete (MKE), az Eötvös Loránd Tudományegyetem Bölcsészettudományi Kar (ELTE BTK) Könyvtár- és Információtudományi Intézet Könyvtártudományi Tanszék vezetője, az Emberi Erőforrások Minisztériuma (EMMI) Könyvtári Akkreditációs Szakbizottság elnöke személyében magyar kollégát is magában foglaló igazgatótanács. ${ }^{19}$ A magas színvonalú könyvtári és információs szolgáltatások egyenlő esélyeket biztosító, ezáltal a társadalmi, kulturális és gazdasági növekedést elösegítő négy nemzetközi stratégiai iránya, valamint az ezekhez kapcsolódó, kétévente felülvizsgálandó kezdeményezések (cselekvési programok):

${ }^{16}$ Részletesebben ld.: Dippold Péter: Trendek az európai könyvtárügyben. = Könyvtári Figyelő, 24. évf. 2014. 1. sz. 71-72. p. http://epa.oszk.hu/00100/00143/00090/pdf/EPA00143 konyvtari_figyelo_2014_1_071-112.pdf; és Sipilä, Sinikka: A könyvtárak és az átalakulás (Libraries and Transformation) címü, a Magyar Könyvtárosok Egyesülete megalakulásának 80. évfordulója alkalmából szervezett konferencián, 2015. november 25-én, az Eötvös Loránd Tudományegyetemen elhangzott elöadásának magyar nyelvü összefoglalója (készítette: Dávid Boglárka). http://docplayer.hu/17806010-2015-november-25-sinikka-sipila-a-konyvtarak-es-azatalakulas-libraries-and-transformation-1.html (2016. október 25.)

${ }^{17}$ IFLA Trend Report 2016 Update: http://trends.ifla.org/update-2016 (2016. október 25.)

${ }^{18}$ IFLA Strategic Plan 2016-2021. Endorsed by the IFLA Governing Board. December 2015. http://www.ifla.org/files/assets/hq/gb/strategic-plan/2016-2021.pdf (2016. október 25.)

${ }^{19}$ IFLA 2015-2017 Governing Board: http://www.ifla.org/governing-board (2016. október 25.) 
1. Könyvtár nélkül nincs társadalom

1.1. Az olvasás és a műveltség - mint az aktív társadalmi részvétel alapvető követelményeinek - támogatása az információhoz való hozzáférés biztosításával bármilyen formában.

1.2. A könyvtárak beillesztése a nemzetközi szervezetek programjába.

1.3. Politikai és akcióterv építése az IFLA trendjelentésére.

1.4. Az IFLA irányelveinek folyamatos fejlesztése annak érdekében, hogy a könyvtárak a közösségek számára megfelelő szolgáltatást nyújthassanak.

2. Információ és tudás méltányosan mindenkinek és mindenkitől

2.1. Hosszú távú, fenntartható információs környezet definiálása.

2.2. Igazságos szerzői jogi keret szorgalmazása.

2.3. Az internetszabályozás jövőjének befolyásolása.

3. Kulturális örökség komplex megőrzése

3.1. A Megörző és Állományvédelmi Központok (Preservation and Conservation Centres $=\mathrm{PACs})^{20}$ hálózatának kialakítása a könyvtári kulturális örökség globális szintü átörökítéséhez.

3.2. Szabványok kidolgozása a gyüjteményekért és a tartalom változatos formáiban történő megörzéséért.

3.3. A könyvtárak kulturális örökségének védelme a katasztrófák kockázatának csökkentésével.

4. Könyvtárak főszerepben a nemzetközi, regionális és globális színtereken (érdekképviselet)

4.1. A könyvtárak szerepének támogatása az ENSZ (Egyesült Nemzetek Szervezete $=$ United Nations, UN) ${ }^{21} 2030$ Fenntartható Fejlődési Keretrendszerben.

4.2. A Nemzetközi Érdekvédelmi Program (International Advocacy Programme $=$ IAP ${ }^{22}$ fejlesztése.

4.3. Vezetöi program fellendítése.

4.4. Az Erős Könyvtári Egyesületek Építése Program (Building Strong Library Associations $=\mathrm{BSLA})^{23}$ kiterjesztése.

4.5. Az IFLA megerősítése a regionális és ágazati kapacitás, valamint részvétel kiépítésével.

\footnotetext{
${ }^{20}$ IFLA Strategic Programme on Preservation and Conservation (PAC): http://www.ifla.org/pac (2016. október 25.)

${ }^{21}$ United Nations (UN): http://www.un.org (2016. október 25.)

${ }^{22}$ IFLA International Advocacy Programme: http://www.ifla.org/node/10092 (2016. október 25.)

${ }^{23}$ IFLA Building Strong Library Associations: http://www.ifla.org/bsla (2016. október 25.)
} 


\section{Az ENSZ és az IFLA Lyoni nyilatkozata}

Az IFLA lyoni világkongresszusán, 2014. augusztus 18-án Sinikka Sipilä, ${ }^{24}$ az IFLA elnöke és Lyon város polgármestere aláirásukkal bocsátották útjára deklarációjukat ${ }^{25}$ melynek célja, hogy az ENSZ a 2015-öt követő fejlesztési időszakban is vegye figyelembe: az információhoz való hozzáférés a fenntartható fejlődés alapfeltétele a demokratikus államokban. Donna Scheeder, ${ }^{26}$ az IFLA leendö elnöke 2015. február 19-én lehetőséget kapott, hogy bemutassa az IFLA dokumentumot az ENSZ közgyülése elött. Barátné Hajdu Ágnes beszámolójában ${ }^{27}$ így foglalja össze a felszólalást: „,... a megnövekedett információs igények kielégitésében elsösorban az olyan információközvetitö intézmények, mint a könyvtárak, játszhatnak/játszanak jelentös szerepet. A könyvtárak segitenek megvalósitani az ENSZ tagállamai által 2015 januárjában New Yorkban meghatározott új programját, a Fenntartható Fejlödési Célokat (Sustainable Development Goals, SDG). Ezek a célok várhatóan 2015 szeptemberétöl lépnek az eddig ismert Millenniumi Fejlesztési Célok (Millennium Development Goals, MDGs) helyébe. ... Donna Scheeder érvekkel támasztotta alá, hogy az információhoz való szabad hozzáférés egy olyan közös alapelv, mely szükségszerüen átszövi valamennyi kitüzött célkitüzést és feladatot. A Lyoni nyilatkozat deklarálja, hogy a megnövekedett információ-felhasználás megalapozza és fejleszti az információs müveltséget, mely egyik nélkülözhetetlen alappillére a fenntartható fejlödésnek. Ezzel a 2015 szeptemberében induló Sustainable Development Goals-nak is az egyik legfontosabb támasza lehet. A nyilatkozatot mára ötszáznál több könyvtáros egyesület, könyvtár és más információs szervezet irta alá, köztük a Magyar Könyvtárosok Egyesülete is. Donna Scheeder rámutatott az információs szegénység és hiány veszélyeire. A leendö elnök asszony emlékeztette a képviselöket, hogy bár nagy figyelmet szentelnek a szegénység különbözö megnyilvánulási formáira, fajtáira, mégsem emlitették eddig az információs szegénységböl eredö hátrányokat, annak ellenére, hogy információ és tudás megkerülhetetlen alapfeltétele a fenntartható fejlödésnek. Az információhoz való hozzáférés nélkül az embereknek pont az az eszköz, esély hiányzik, amely jobbá teheti az életüket. A hozzáférés lehetöségeinek növekedésével elösegitjük a teljesitmények emelkedését és a kitüzött célok megvalósitását az érintett valamennyi terület tekintetében, beleértve az egészségügyet, az oktatást, az átláthatóságot, valamint a felelösségre vonhatóságot. ... A világszerte több mint 320.000 közkönyvtár, az iskolai és tudományos könyvtárak százezrei ott állnak és készek segíteni ebben a folyamatban. A könyvtárosok, akik jártas és képzett információs szakemberek, fontos és megbizható partnerei az embereknek, így az ENSZ-nek is, abban, hogy

${ }^{24}$ Sinikka Sipilä: http://www.ifla.org/past-presidents/sinikka-sipila (2016. október 25.)

${ }^{25}$ The Lyon Declaration: http://www.lyondeclaration.org (2016. október 25.)

${ }^{26}$ Donna Scheeder: http://www.ifla.org/president (2016. október 25.)

${ }^{27}$ IFLA takes Lyon Declaration to the UN, 23 February 2015: http://www.ifla.org/node/9427 (2016. október 25.) 
növeljék az információ hozzáférés esélyeit és gyarapitsák az információs müveltség kompetenciáit, és ezzel jobbá tegyék a lakosok életét." ${ }^{28}$

\section{Az ENSZ és az IFLA a fenntartható fejlődésért}

A nemzetközi fejlesztés előmozdítása az ENSZ alapítástól érvényes küldetése. A 2000-2015 közötti időszakra elfogadott Millenniumi Fejlesztési Program ${ }^{29}$ célja a szegénység és az éhezés mérséklése volt, de már az 1992-től érvényes Feladatok a 21. századra elnevezésü ENSZ-projekt a fenntartható fejlődés megteremtésében látta a sokasodó környezeti problémák kezelését. A két koncepció együttesét a Világunk Átalakitása: a Fenntartható Fejlödés 2030-ig Program (továbbiakban: Világunk 2030-ig Program vagy ENSZ 2030-as Keretrendszer) ${ }^{30}$ teremtette meg, mely általános érvényü, egyetemes célrendszert foglal magában, de kiemelten kezeli a fejlődő országok támogatását a 2 . ábrán olvasható prioritásokkal. ${ }^{31}$

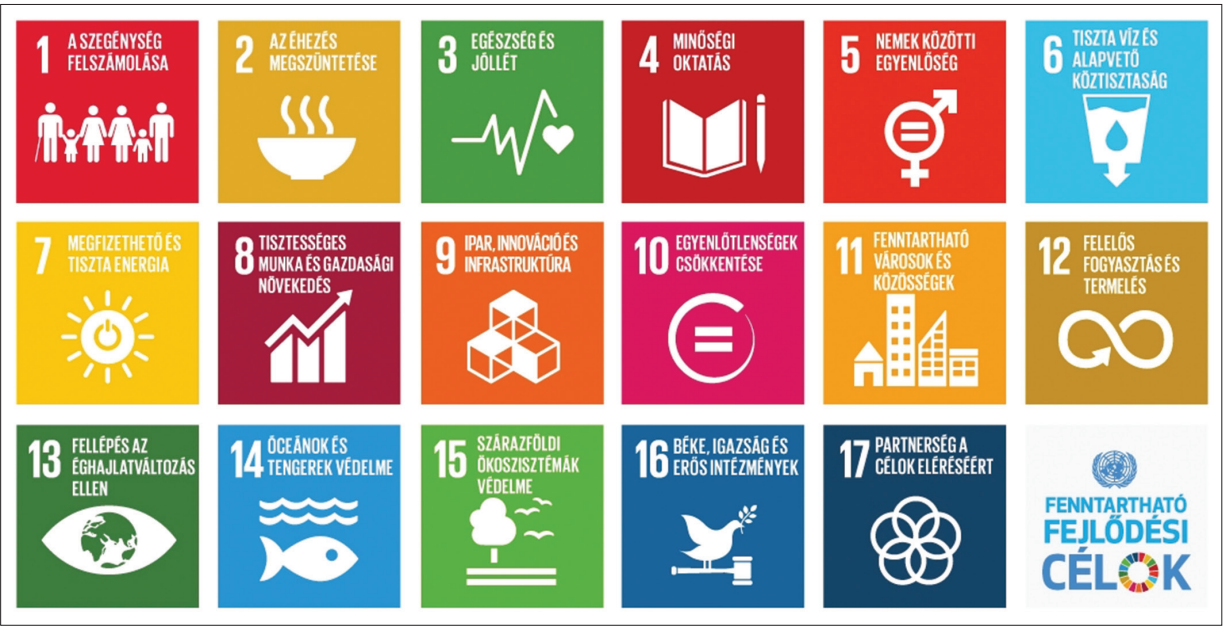

2. ábra. Az ENSZ által meghatározott fenntartható fejlődési célok 2030-ig ${ }^{32}$

${ }^{28}$ Barátné Hajdu Ágnes: A Lyoni nyilatkozat az ENSZ előtt. = Könyvtárvilág, 3. évf. 2015. 2. sz. http://mke.info.hu/konyvtarvilag/2015/05/ifla-a-lyoni-nyilatkozat-az-ensz-elott/2133 (2016. október 25.)

${ }^{29}$ United Nations. Millennium Development Goals: http://www.un.org/millenniumgoals (2016. október 25.)

${ }^{30}$ United Nations. A/RES/70/1. Transforming our world: the 2030 Agenda for Sustainable Development. Resolution adopted by the General Assembly on 25 September 2015. 70/1.: http:// www.un.org/ga/search/view_doc.asp?symbol=A/RES/70/1\&Lang=E; és United Nations Sustainable Development: https://sustainabledevelopment.un.org (2016. október 25.)

${ }^{31}$ Részletesen ld.: Faragó Tibor: A fenntartható fejlődés új ENSZ-programja. 2015. szeptember 25.9 p. http://www.menszt.hu/content/download/3185/12907/file/SDGsFarag\%C3\%B3Tibor. pdf; és Magyar ENSZ Társaság Fenntartható fejlődési célok: http://www.menszt.hu/tudnivalok_ az_egyesult_nemzetek_szervezeterol/fenntarthato_fejlodesi_celok (2016. október 25.)

${ }^{32}$ Forrás: http://www.menszt.hu/content/download/3233/13031/file/SDGs_HU_final_UNIS.jpg (2016. október 25.) 
A Lyoni deklaráció után az IFLA - mint a kidolgozásba bevont érdekelt fél - üdvözölte a Világunk 2030-ig Program 2015. szeptember 25-i elfogadását az ENSZ New Yorkban tartott csúcstalálkozóján. Ezt követően viharos gyorsasággal - korábbi segédletét ${ }^{33}$ aktualizálva - 2015 októberében közzétette a Könyvtárak a Világunk 2030-ig Program megvalósitásában címü útmutatóját, ${ }^{34}$ melynek felépítése: 1. Az ENSZ 2030-as Keretrendszerének és az IFLA állásfoglalásának megértése. 2. Az ENSZ 2030-as Keretrendszere jövőbeni nemzeti szintü végrehajtásának megértése.

3. A döntéshozókkal való találkozók megszervezése.

4. Az ENSZ 2030-as Keretrendszer és a Fenntartható Fejlődési Célok megvalósításának figyelemmel kísérése.

5. A könyvtárhasználók tájékoztatása a Fenntartható Fejlődési Célokról.

1. függelék: Mintalevél: Könyvtáros egyesületek kapcsolatba lépése politikai döntéshozókkal.

2. függelék: Tájékoztató (handout): A könyvtárak és az információhoz való hozzáférés jelentősen hozzájárul a nemzeti fejlődéshez.

3. függelék: A könyvtárak miként tudnak megfelelni a 17 Fenntartható Fejlődési Célnak.

4. függelék: Javaslatok az indikátorokkal kapcsolatban.

Az alábbiakban rendhagyó módon néhány - megítélésünk szerint - kiemelt megállapítást idézünk a szakértői anyagból:

„,... a Fenntartható Fejlödési Célok (Sustainable Development Goals, SDGs) univerzálisak, minden ország maga felelös a nemzeti szintü stratégiájának kidolgozásáért és végrehajtásáért a célok elérése érdekében..."

„A könyvtárak kulcsfontosságú intézmények a célok eléréséhez."

„Ha az információhoz és a könyvtárakhoz való hozzáférést a nemzeti fejlesztési tervek nem tartalmazzák, az több mint egy elszalasztott lehetöség. Elöfordulhat, hogy a kormányok figyelmen kivül hagyják a könyvtárakat, és más szervezeteket biznak meg a nyilt hozzáférés, az információk és a használatukhoz kellö készségek biztosításával, vagy egyáltalán nem ismerik fel a nyilt hozzáférés szükségességét. Ennek az eszközkészletnek a segitségével demonstrálni tudja majd a könyvtárak szerepének fontosságát az egészségügyi, oktatási, gazdasági és kulturális célok elérésében, és

${ }^{33}$ Toolkit: Libraries and the post-2015 development agenda. January 2015. Second version. 28 p. http://www.ifla.org/files/assets/hq/topics/libraries-development/documents/ifla-post-2015-a2ilibraries-toolkit-v2.pdf (2016. október 25.)

${ }^{34}$ Libraries and implementation of the UN 2030 Agenda. October 2015. First version. 19 p. http://www.ifla.org/files/assets/hq/topics/libraries-development/documents/libraries-un-2030-agendatoolkit.pdf (2016. október 25.) 
képes lesz a kormány felé jelezni, hogy a magas színvonalú könyvtári programokhoz és szolgáltatásokhoz elengedhetetlen a megfelelö források rendelkezésre bocsátása."

„A tudástársadalom többet jelent az internet-hozzáférésnél."

„,Világszerte 320.000 közkönyvtár és több mint egymillió országgyülési, nemzeti, egyetemi, kutatóintézeti, iskolai, tudományos és szakkönyvtár biztositja, hogy az információ és a használatához kellö készségek mindenki számára elérhetök legyenek, és ezáltal kritikus fontosságú intézménnyé váltak a digitális korban is. A könyvtárak az információs és kommunikációs technológiák infrastruktúráját szolgáltatják, segitik az embereket az információ eredményes használatához szükséges képesség kifejlesztésében, és megőrzik az információt, hogy az a jövö generációi számára is hozzáférhetö legyen. Helyi intézmények régóta fennálló, megbizható hálózatát kinálják, amely hatékonyan el tudja érni a lakosság bármely részét."

„A könyvtárak szolgáltatásai a következőkkel járulnak hozzá a Fenntartható Fejlődési Célok teljesebb megvalósulásához:

a) Az általános müveltség, azon belül a média- és információs müveltség, valamint a digitális müveltség támogatása;

b) az információhoz való hozzáférés hiányosságainak megszüntetése, valamint a kormány, a civil társadalom és az üzleti szféra segitése a helyi információs igények mélyebb megértésében;

c) a kormány programjai és szolgáltatásai számára kézbesitö csatornák hálózatának biztositása;

d) a digitális befogadás elömozditása az információs és kommunikációs technológiákhoz való hozzáféréssel, és az emberek új digitális készségeinek kifejlesztésében elkötelezett munkatársakkal;

e) a tudományos közösség szolgálása, annak központi szerveként;

f) a világ kultúrájának és örökségének megörzése és hozzáférhetővé tétele."

„A könyvtárak bevált, költséghatékony partnerek a fejlesztési prioritások elömozditásában."

A világ különböző országaiból származó, minden egyes célhoz konkrét, meggyőző gyakorlati példákat felvonultató Hozzáférés és lehetöség mindenkinek. Hogyan járulnak hozzá a könyvtárak a Világunk 2030-ig Programhoz címủ színes brosúra (3. ábra), ${ }^{35}$ valamint mellette egy kétoldalas rövid ismertetö ${ }^{36}$ a könyvtárak

\footnotetext{
${ }^{35}$ Acces and oppurtunity for all. How libraries contribute to the United Nations 2030 Agenda http://www.ifla.org/files/assets/hq/topics/libraries-development/documents/access-and-opportunityfor-all.pdf (2016. október 25.)

${ }^{36}$ Libraries can drive progress across the entire UN 2030 Agenda http://www.ifla.org/files/ assets/hq/topics/libraries-development/documents/sdgs-insert.pdf (2016. október 25.)
} 
fenntartható fejlődés megteremtésében vállalt valódi, mindennapokban betöltött szerepét mutatja be:

1. cél - A szegénység felszámolása

a) Az információkhoz és a forrásokhoz való nyílt hozzáférés, amely lehetőséget ad az embereknek az életminőségük javítására.

b) Képzés az oktatáshoz és a munkavállaláshoz szükséges új készségek kialakításához.

c) Információ a kormányok, a civil társadalom és az üzleti szféra döntéshozatalának támogatására a szegénység elleni küzdelemben.

2. cél - Az éhezés megszüntetése

a) Mezőgazdasági kutatás és adatok a termények produktívabbá és fenntarthatóbbá tételéről.

b) Online forrásokhoz való nyílt hozzáférés biztosítása a gazdálkodók számára (pl. a helyi piac árai, időjárás-jelentések, új eszközök).

3. cél - Egészség és jólét

a) Az egészségügyi intézmények könyvtáraiban elérhető kutatások, melyek támogatják az oktatást és fejlesztik az orvosi gyakorlatokat.

b) Nyílt hozzáférés egészségügyi és wellness információkhoz a közkönyvtárakban, amely segíti az egyének és a családok egészségmegőrzését.

4. cél - Minőségi oktatás

a) Elkötelezett munkatársak, akik támogatják a korai írni-olvasni tudást és az élethosszig tartó tanulást.

b) A diákok információhoz és kutatásokhoz való hozzáférése világszinten.

c) Befogadó helyek, ahol nem akadályozzák költségek az új ismeretek és képességek elsajátítását.

5. cél - Nemek közötti egyenlöség

a) Biztonságos és barátságos találkozóhelyek.

b) Programok és szolgáltatások a nők és lányok igényeire szabva (pl. jog és egészség).

c) Olyan információkhoz, valamint információs és kommunikációs technológiákhoz való hozzáférés, amelyek segítik a nők üzleti készségeinek kialakítását.

6. cél - Tiszta víz és alapvető köztisztaság

7. cél - Megfizethetô és tiszta energia

a) Minőségi információkhoz és jó gyakorlatokhoz való hozzáférés, amely támogatja a helyi vízgazdálkodást és a csatornázási projekteket.

b) Szabad és megbízható hozzáférés az olvasáshoz, a tanuláshoz és a munkához szükséges villamos energiához, illetve fényhez.

8. cél - Tisztességes munka és gazdasági növekedés 
a) Információhoz és készségfejlesztő képzésekhez való hozzáférés, melyek az embereknek a jobb munkahely megtalálásához, megpályázásához és a helytálláshoz szükségesek.

9. cél - Ipar, innováció és infrastruktúra

a) Köz- és szakkönyvtárak széleskörü infrastruktúrája képzett könyvtáros szakemberekkel.

b) Barátságos és befogadó közösségi terek.

c) Hozzáférés az információs és kommunikációs technológiához (pl. nagy sebességü internet, amely nem feltétlenül érhető el máshol).

10. cél - Egyenlőtlenségek csökkentése

a) Semleges és barátságos terek, melyek a tanulást mindenki számára elérhetővé teszik, ideértve az olyan marginalizált csoportokat, mint a bevándorlók, a menekültek, a kisebbségek, az öslakosok és a fogyatékkal élő személyek.

b) Egyenlő hozzáférés az információhoz, amely támogatja a társadalmi, politikai és gazdasági befogadást.

11. cél - Fenntartható városok és közösségek

a) A kulturális befogadás és megértés támogatásának szentelt megbízható intézmények.

b) A kulturális örökség dokumentálása és megőrzése a jövő generációi számára.

12. cél - Felelös fogyasztás és termelés

13. cél - Fellépés az éghajlatváltozás ellen

14. cél - Óceánok és tengerek védelme

15. cél - Szárazföldi ökoszisztémák védelme

a) Anyagok megosztásának és kölcsönzésének fenntartható rendszere, amely csökkenti a hulladékmennyiséget.

b) Történelmi feljegyzések a partok változásáról és a földhasználatról.

c) Az éghajlat-változási politikához szükséges kutatások és adatok.

d) Széleskörü hozzáférés az önkormányzatok és a nemzeti kormányok döntéshozatalának irányításához szükséges információkhoz az olyan témákban, mint a vadászat, a halászat, a földhasználat és a vízgazdálkodás.

16. cél - Béke, igazság és erős intézmények

a) Nyílt hozzáférés a kormányzatról, a civil társadalomról és más intézményekről szóló információkhoz.

b) Képzés az ilyen jellegü információk megértéséhez és felhasználásához szükséges készségek kifejlesztéséhez.

c) Befogadó és politikailag semleges találkozási helyek.

17. cél - Partnerség a célok eléréséért

a) Közösségeken alapuló intézmények globális hálózata, melyek elsődleges célja a helyi fejlesztési tervek támogatása. 


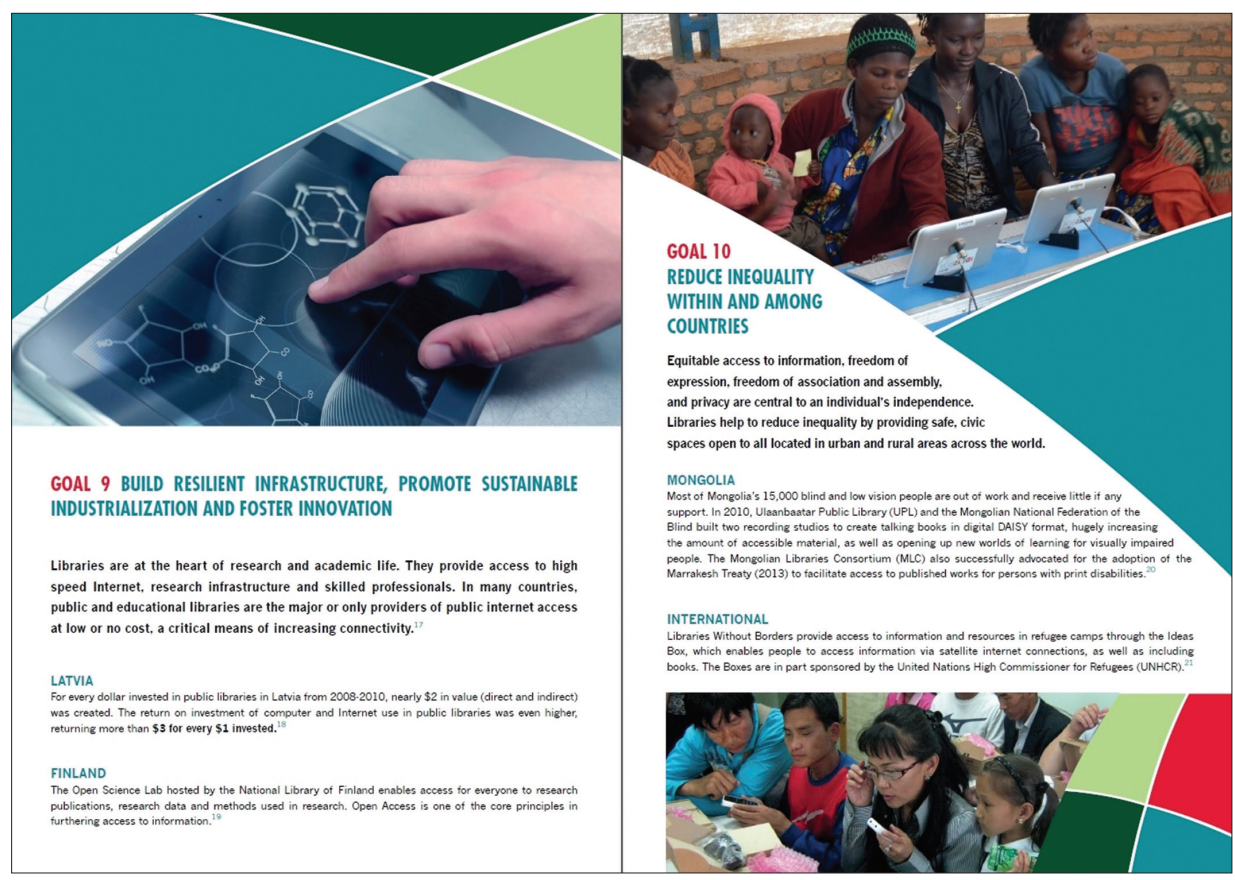

3. ábra. Részlet az IFLA Acces and oppurtunity for all. How libraries contribute to the United Nations 2030 Agenda című kiadványából ${ }^{37}$

\section{Hazai sodorvonalak}

A kulturális ágazati irányítás által követendőnek tekintett utolsó önálló stratégiaként a Portál Programnak nevezett, 2008-2013 közötti idöszakra szóló könyvtárfejlesztési koncepció ${ }^{38}$ tanulmányozható. Ennek folytatásaként országosan iránymutató dokumentumot nem ismerünk. ${ }^{39}$ Bár a szaksajtóban találkozhatunk a 2014-2018 közötti szakasz előkészítésére vonatkozó utalással, ${ }^{40}$ a szakmai ori-

37 Forrás: http://www.ifla.org/files/assets/hq/topics/libraries-development/documents/accessand-opportunity-for-all.pdf (2016. október 25.)

${ }^{38}$ Koncepció a könyvtárfejlesztésről. Portál program - a könyvtárügy stratégiája 2008-2013. Budapest, 2007. december. 5 p. http://ki.oszk.hu/sites/ki.oszk.hu/files/dokumentumok/portl_miniszteri_elfogadott_1.rtf (2016. október 25.)

${ }^{39}$ A hiányra az egyes intézményi stratégiák is rávilágítanak, pl.: „Tekintettel arra, hogy nem készült el a 2014-től érvényes országos könyvtári stratégia, így ahhoz való igazodás nem lehetséges.” Forrás: A József Attila Megyei és Városi Könyvtár stratégiája 2015-2020. http://www.jamk. hu/?q=hu/konyvtarunk/strategia (2016. október 25.)

${ }^{40}$ Skaliczki Judit: Az új stratégia alapja egy új szakmapolitikai koncepció. A 2014-2018 közötti országos könyvtári stratégia elökészítéséhez. = Könyv, Könyvtár, Könyvtáros, 21. évf. 2012. 8. sz. 10-17. p. http://epa.oszk.hu/01300/01367/00204/pdf/EPA01367_3K_2012_08_10-17.pdf 
entáció jellemzően jogszabályok, ${ }^{41}$ nagyprojektek ${ }^{42}$ és pályázatok ${ }^{43}$ segítségével valósul meg napjainkban. Itt említhető meg a Minősített Könyvtár cím és a Könyvtári Minőség Díj ${ }^{44}$ elnyerését katalizáló Könyvtári Közös Értékelési Keretrendszer (KKÉK), ${ }^{45}$ mely a minőségbiztosítás révén tölt be bizonyos stratégiai célokat. Az EMMI képviselői különféle szakmai rendezvényeken vázolják fel az ágazati prioritásokat, ${ }^{46}$ és a képzőhelyek is bevonják a szakma neves képviselőit a trendek hallgatók számára történő naprakész azonosításába, gyakorlati alkalmazásába. ${ }^{47} \mathrm{Az}$ elkövetkezendő évek izgalmas, az egész hazai könyvtár hálózatra befolyással bíró kérdése nemzeti könyvtárunk, az Országos Széchényi Könyvtár hosszú távú fejlesztésének alakulása. ${ }^{48}$

${ }^{41}$ Pl.: 1997. évi CXL. törvény a muzeális intézményekröl, a nyilvános könyvtári ellátásról és a közmủvelődésről; 30/2014. (IV. 10.) EMMI rendelet az országos múzeum, az országos szakmúzeum, a nemzeti könyvtár, az országos szakkönyvtár és az állami egyetem könyvtárának kiemelt feladatairól; 1486/2015. (VII. 21.) Korm. határozat a Digitális Nemzet Fejlesztési Program megvalósításával kapcsolatos aktuális feladatokról, valamint egyes kapcsolódó kormányhatározatok módosításáról.

${ }^{42}$ Pl.: ELektronikus Dokumentumküldés Országos Rendszere, Adatbázisa és Dokumentumtára - ELDORADO: https://eldorado.oszk.hu (2016. október 25.)

${ }^{43}$ Pl.: EFOP-1.3.1-15 Cselekvő közösségek - aktív közösségi szerepvállalás https:// www.palyazat.gov.hu/efop-131-15-cselekv-kzssgek-aktv-kzssgi-szerepvllals; és EFOP-3.3.3VEKOP/16 Országos múzeumi és könyvtári központi fejlesztés https://www.palyazat.gov.hu/ efop-333-vekop-16-orszgos-mzeumi-s-knyvtri-kzponti-fejleszts (2016. október 25.)

${ }^{44}$ 12/2010. (III. 11.) OKM rendelet a Minősített Könyvtár cím és a Könyvtári Minőségi Díj adományozásáról http://net.jogtar.hu/jr/gen/hjegy_doc.cgi?docid=A1000012.OKM; és OSZK Könyvtári Intézet. Pályázat a Minősített Könyvtár címre és a Könyvtári Minőségi Díjra: http:// ki.oszk.hu/content/p-ly-zat-min-s-tett-k-nyvt-r-c-mre-s-k-nyvt-ri-min-s-gi-d-jra (2016. október 25.)

45 EMMI. Könyvtári Közös Értékelési Keretrendszer. A könyvtári önértékelés szakmai szempontjai. Budapest, 2010. 39 p. http://www.kormany.hu/download/c/8d/50000/

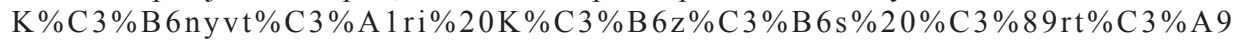
kel\%C3\%A9si\%20Keretrendszer.doc (2016. október 25.)

${ }^{46}$ Erre jó alkalmat adnak az MKE éves vándorgyülései, két példa: Sörény Edina: A könyvtári stratégia céljai 2014-2020. Előadás 2013. július 18-án Egerben, az MKE 45. vándorgyülésének Stratégia előtt címü kisplenáris ülésén http://mke.info.hu/konyvtarvilag/files/2013/08/A-k\%C3\%B6nyvt\%C3\%A1ristrat\%C3\%A9gia-c\%C3\%A9ljai-2014-2020_Soreny-Edina.pdf; és Sepsey Tamásné Vígh Annamária köszöntője 2016. július 7-én, az MKE 48. vándorgyülésének nyitó plenáris ülésén Veszprémben. http://vandorgyules.ekmk.hu/index.php/program/programok (2016. október 25.)

${ }^{47}$ Az ELTE BTK Könyvtár- és Információtudományi Intézetének kezdeményezéseit ismerteti: Kiszl Péter: Tudományos örökség és gyorsuló fejlődés - könyvtárosképzés az Eötvös Loránd Tudományegyetemen. = Könyvtári Figyelő. 25. évf. 2015. 4. sz. 443-462. p. http://ki.oszk. $\mathrm{hu} / \mathrm{kf} / 2016 / 01 /$ tudomanyos-orokseg-es-gyorsulo-fejlodes-\%E2\%80\%93-konyvtaroskepzes-azeotvos-lorand-tudomanyegyetemen; és uő: Generációk találkozása: kérdések és válaszok napjaink könyvtárügyéről. = Könyvtári Levelezö/lap, 28. évf. 2016. 8. sz. 7-13. p. http://kll.org.hu/cikk/ xxviii/08-4/generaciok-talalkozasa-kerdesek-es-valaszok-napjaink-konyvtarugyerol

${ }^{48}$ 1316/2016.(VII.1.)Korm. határozat az Országos Széchényi Könyvtárhosszútávú stratégiájának megvalósításából adódó feladatokról http://njt.hu/cgi_bin/njt_doc.cgi?docid=196279.324032; és 1387/2016. (VII. 21.) Korm. határozat az Országos Széchényi Könyvtár fejlesztésével összefüggő feladatokról http://njt.hu/cgi_bin/njt_doc.cgi?docid=196596.324873 (2016. október 25.) 
A szakmai szervezetek is igyekeznek rendezvények szervezésével, nemzetközi szakértői anyagok magyar nyelvü közzétételével, hazai és külföldi grémiumokban történő szerepvállalással előmozdítani a jövő tervezését és a lobbitevékenységet. Az MKE 2016. november 9. és 22. napjára tervezett Fejlesztés, fenntarthatóság, esély az IFLA trendek és a Lyoni deklaráció tükrében címü, hiánypótló konferenciája keretében az említett dokumentumokban megfogalmazottakra adható magyar válaszokról, megoldásokról és eredményekről lesz szó. ${ }^{49} \mathrm{Az}$ MKE aktív közremüködője a Public Libraries 2020 (PL2020) EU-s kezdeményezésnek, ${ }^{50}$ a magyar adatok infografikán olvashatók és hasonlíthatók össze az európai mezőnnyel. ${ }^{51}$ Az MKE, valamint az Informatikai és Könyvtári Szövetség (IKSZ) által delegált tagokból 2014-ben alakult meg a könyvtáros életpályamodell munkacsoport, ${ }^{52}$ az IKSZ pedig alapító tagja az EMMIkezdeményezésủ Kulturális Alapellátási Kerekasztalának. ${ }^{53}$

Intézményi szinten példamutató a Fővárosi Szabó Ervin Könyvtár (FSZEK) 2014-2020 közötti időszakra vonatkozó Informálni, integrálni, inspirálni mottójú stratégiai terve, ${ }^{54}$ melyhez szakmai rendezvény(sorozat) is társul. ${ }^{55}$ Ugyanígy meg kell említenünk az ELTE Egyetemi Könyvtár 2016-ban immár ötödik részéhez érkezett Hagyományok és kihívások szakmai napját ${ }^{56}$ melynek keretében

${ }^{49}$ Fejlesztés, fenntarthatóság, esély az IFLA trendek és a Lyoni deklaráció tükrében szakmai konferencia - 2016. november 9. és 22. http://mke.info.hu/blog/2016/09/fejlesztesfenntarthatosag-esely-az-ifla-trendek-es-a-lyoni-deklaracio-tukreben-szakmai-konferencia-2016november-9-es-23 (2016. október 25.)

${ }^{50}$ Public Libraries 2020: http://www.publiclibraries2020.eu (2016. október 25.)

${ }^{51}$ Public Libraries 2020 Library factsheets per country: http://www.publiclibraries2020.eu/ content/country-factsheets (2016. október 25.). Vö. az amerikai trendekkel: Barton Dávid - Kiszl Péter: Könyvtári infografikák - tényképek a tengerentúlról. = Tudományos és Müszaki Tájékoztatás. 62. évf. 2015.9. sz. 314-332. p. http://tmt.omikk.bme.hu/show_news.html?id=6083\&issue_id=573

${ }^{52}$ Barátné Hajdu Ágnes: Könyvtáros életpálya, tudatos karrierépítés. = Valóságos könyvtár könyvtári valóság II.: Konferenciaprogram az előadások tartalmi összefoglalóival. Szerk. Boda Gáborné Köntös Nelli - Kiszl Péter. Budapest, ELTE BTK Könyvtár- és Információtudományi Intézet. 2015. 10. p. http://lis.elte.hu/KONYVTAR/pdf/2015_Vkkv2_absztraktkotet.pdf; és EMMI. Új kihívások elött a könyvtári szakma. 2014. november 26. http:/www.kormany.hu/hu/emberieroforrasok-miniszteriuma/kulturaert-felelos-allamtitkarsag/hirek/uj-kihivasok-elott-a-konyvtariszakma (2016. október 25.)

${ }^{53}$ EMMI. Megalakult a Kulturális Alapellátás Kerekasztala. 2014. szeptember 30. http://www. kormany.hu/hu/emberi-eroforrasok-miniszteriuma/hirek/megalakult-a-kulturalis-alapellataskerekasztala (2016. október 25.)

${ }^{54}$ Informálni, integrálni, inspirálni. A Fővárosi Szabó Ervin Könyvtár stratégiai terve 2014-2020. 2014. december. 1. 46 p. http://www.fszek.hu/?tPath=/view/\&documentview type $=$ save \&documentview_site $=4607 \&$ documentview_id=17546 (2016. október 25.)

${ }^{55}$ Informálni, integrálni, inspirálni - közkönyvtárak a XXI. században: http://www.fszek. hu/?article hid=31467 (2016. október 25 .)

${ }^{56}$ Hagyományok és kihívások V. - Országos könyvtárszakmai rendezvény az Egyetemi Könyvtárban: https://konyvtar.elte.hu/hu/cikk/hagyomanyok-es-kihivasok-v-orszagos-konyvtarszakmairendezveny-az-egyetemi-konyvtarban (2016. október 25.) 
jelen közlemény alapjául szolgáló előadás is elhangzott. Többkörös egyeztetés után elfogadásra vár az ELTE Egyetemi Könyvtári Szolgálat (EKSZ) stratégiája, az ELTE Egyetemi Könyvtára - bevált nemzetközi gyakorlatokat követve - az Egyetemi Könyvtárért Alapítvány ${ }^{57}$ segítségével szervezi külső források bevonására irányuló, átfogó támogatói programját. ${ }^{58}$

A képzés folyamatos korszerüsítése, az országos szakmai álláspontok kialakítása, illetve az intézményi vélemények egységesítése érdekében a Debreceni Egyetem, az Eötvös Loránd Tudományegyetem, az Eszterházy Károly Főiskola, a Nyugat-magyarországi Egyetem, a Pécsi Tudományegyetem, a Szegedi Tudományegyetem, valamint az Egyetemi Könyvtárigazgatók Kollégiuma, az Informatikai és Könyvtári Szövetség, illetve a Magyar Könyvtárosok Egyesülete képviselöi 2015. március 24-én az ELTE BTK-n tartott ülésükön megalapították a Könyvtárés Információtudományi Képzések Kollégiumát (KIKK). ${ }^{59}$ Az oktatásfejlesztési grémium példaértékủ munkájával - e tanulmányban is tárgyalt nemzetközi szakmai programok adaptálásával - készültek el az informatikus könyvtáros alapszak és a könyvtártudomány mesterszak képzési és kimeneti követelményei (KKK). ${ }^{60}$

Az ELTE BTK Könyvtár- és Információtudományi Intézete 2013 novemberében indította el Valóságos könyvtár - könyvtári valóság címü kétévente, a Magyar Tudomány Ünnepe keretében látogatható immár kétnapos, nemzetközi konferenciáját, ahol ugyancsak lehetőség nyílik a külföldi és hazai trendek, valamint stratégiai célok tárgyalására. ${ }^{61}$ A 2015 -ös ülés félszáz előadója közül nehéz néhányat kiemelni. Vendégünk volt többek között Silvia Stasselová, a Szlovák Könyvtárak és Könyvtárosok Egyesülete elnöke, a pozsonyi Egyetemi Könyvtár föigazgatója, aki a modern könyvtárépítészetről tartott előadást, de gazdag könyvtárhasználói tapasztalatairól számolt be külföldi kitekintéssel Frank Tibor

${ }^{57}$ Egyetemi Könyvtárért Alapítvány: https://konyvtar.elte.hu/egyetemi-konyvtarert-alapitvany (2016. október 25.)

${ }^{58}$ Bővebben ld.: Kiszl Péter: Alapítvány a könyvtárért: közgyüjteményi forrásteremtés civil eszközökkel. = Tudományos és Müszaki Tájékoztatás. 62. évf. 2015. 6. sz. 223-245. p. http:// tmt.omikk.bme.hu/show_news.html?id=6064\&issue_id=571; és uő: Külső források bevonása az Eötvös Loránd Tudományegyetem Egyetemi Könyvtárában. = Hagyományok és kihívások. Szerk. Knapp Éva - Vajda Zsuzsanna. Budapest, ELTE Egyetemi Könyvtár. 2014. 9-20. p.

${ }^{59}$ Bővebben 1. Kiszl Péter: Az informatikus könyvtáros alap- és mesterszak aktualitásairól a Könyvtár- és Információtudományi Képzések Kollégiuma megalakulásának tükrében. $=$ Könyvtári Levelezö/lap, 27. évf. 2015. 7. sz. 3-12. p.; és uö: Újratervezés a könyvtárosképzésben. = Tudományos és Müszaki Tájékoztatás. 62. évf. 2015. 11-12. sz. 399-414. p. http://tmt.omikk.bme. hu/show_news.html?id=6126\&issue id=575 (2016. október 25.)

${ }^{60} 18 / 2016$. (VIII. 5.) EMMI rendelet a felsőoktatási szakképzések, az alap- és mesterképzések képzési és kimeneti követelményeiröl, valamint a tanári felkészítés közös követelményeiről és az egyes tanárszakok képzési és kimeneti követelményeiről szóló 8/2013. (I. 30.) EMMI rendelet módosításáról. http://njt.hu/cgi_bin/njt_doc.cgi?docid=196922.325525 (2016. október 25.)

${ }^{61}$ ELTE BTK Könyvtár- és Információtudományi Intézet. Valóságos könyvtár - könyvtári valóság konferencia: http://lis.elte.hu/vkkv (2016. október 25.) 
történész, akadémikus, és Déri Balázs klasszika-filológus tanszékvezető profeszszor, valamint természetesen a stratégiai tervezés is napirendre került Fodor Péter, a FSZEK főigazgatója prezentálásában. ${ }^{62}$

\section{Fejlődés és felelősség}

Stratégiai körképünk is egyértelmüen bizonyítja, hogy a könyvtár évezredes kultúraközvetítő, klasszikus szerepe a 21. századra jelentősen kiegészül: napjainkban multifunkciós intézményröl beszélhetünk, mely komplex szolgáltatásokkal áll használói rendelkezésére. A könyvtár segít a társadalmi különbségek mérséklésében, bárki használhatja a brókertől a fedél nélküliig. A könyvtárban lehet internetezni, segítséget kérni az adóbevallás kitöltésében, vagy a könyvesboltban árult, frissen megjelent regényt ingyenesen kikölcsönözni, akár egy jó szót kapni. A világon, az Európai Unióban és hazánkban is a legnagyobb kulturális intézményrendszer a könyvtári hálózat, amely nyitott, mindenki számára szabadon hozzáférhető. Ha ehhez hozzávesszük a felsőoktatási könyvtárak kiemelt feladataként a jövő generációjának, a leendő tudós- és tanárnemzedéknek, a kutatás-fejlesztés letéteményeseinek a szolgálatát, akkor minden eddigi korszaknál jelentősebb szakmai felelösségünkhöz nem fér kétség. ${ }^{63}$

\section{Rezümé}

A tanulmány a könyvtárak 21. századi - jelentösen kibővült - funkciórendszerét, társadalomban betöltött aktív közösségi szerepét elemzi, és felhívja a figyelmet a környezeti tényezők folyamatos változására, a prognózisok jelentőségére az ezekből származtatható új igények proaktív kiszolgálásában. A könyvtári hálózatra vonatozó stratégai tervezés sarokpontjainak kijelölését követöen - a magyarországi adaptálás előmozdítását szorgalmazva - nemzetközi helyzetképet vázol fel az IFLA (International Federation of Library Associations and Institutions = Könyvtári Egyesületek és Szervezetek Nemzetközi Szövetsége) fejlesztési törekvéseinek és vonatkozó programjainak bemutatásával. A közlemény az IFLA 2013-ban megjelent trendjelentéséből (IFLA Trend Report), majd annak aktualizálásából (IFLA Trend Report 2016 Update) kiindulva tárgyalja a Lyoni nyilatkozatot (The Lyon Declaration), valamint az IFLA 2016-2021 közötti stratégiai tervét (IFLA Strategic Plan 2016-2021). Súlyponti elemnek az IFLA Fenntartható Fejlödési Célok (Sustainable Develpoment Goals, SDGs) megvalósításában vállalt - az Egyesült Nemzetek Szervezete $($ ENSZ, United Nations $=$ UN) Világunk 2030-ig Keretrendszerére (Transforming our world: the 2030 Agenda for Sustainable Development) épülö - komplex

${ }^{62}$ ELTE BTK Könyvtár- és Információtudományi Intézet Valóságos könyvtár - könyvtári valóság II. konferencia programja absztraktokkal és prezentációkkal: http://lis.elte.hu/vkkv/VKKV2; és Boda Gáborné Köntös Nelli - Kiszl Péter szerk.: i. m.

${ }^{63}$ Az IFLA Trend Report címe is erre utal: Riding the Waves or Caught in the Tide? Navigating the Evolving Information Environment 16 p. http://trends.ifla.org/files/trends/assets/insights-fromthe-ifla-trend-report_v3.pdf (2016. október 25.) 
cselekvési tervét, illetve az ehhez kapcsolódó gazdag dokumentációs hátterét (útmutatók, segédletek) tekinti, de a magyarországi könyvtári irányvonalak és tendenciák érzékeltetésének is teret enged.

\section{IFLA's Strategic Objectives - Hungarian and International Library Parallels}

This study analyses the - significantly expanded - functions of libraries in the 21 th century and their active community role in society, and draws attention to the continuous changes of environmental factors in proactive serving of the new demands derived from them. After appointing the corners of the strategic planning carried out for the library network based on prognoses, it outlines the international situation by introducing the development efforts and programs of IFLA (International Federation of Library Associations and Institutions), promoting the Hungarian adaptation. The study discusses the Lyon Declaration and the IFLA Strategic Plan 2016-2021 on the basis of the IFLA Trend Report 2013 and its update, the IFLA Trend Report 2016. It considers the IFLA's complex action plan - built on the UN Transforming our world: the 2030 Agenda for Sustainable Development - for implementing the Sustainable Development Goals (SDGs) and the related rich documentation background (manuals, toolkits) as the crucial elements; however it leaves scope for the introduction of the Hungarian library trends and tendencies as well.

KISZL PÉTER
intézetigazgató

ELTE Eötvös Loránd Tudományegyetem Bölcsészettudományi Kar Könyvtár- és Információtudományi Intézet ORCID: 0000-0003-2992-295X 


\section{Hogyan csapjuk az online szelet az Y generáció számára?}

\section{Bevezetés}

Tanulmányomban bemutatom, hogy online eszközök segítségével a felsőoktatási könyvtári szférában hogyan tudjuk leghatékonyabban elérni az Y generációt, tehát azokat a fiatalokat, akik már úgy nőttek fel, hogy kommunikációjukban jelentős szerepet kaptak azt internetes kapcsolatteremtési lehetőségek. Látni fogjuk, hogy másképpen célszerü velük kommunikálni, mint például azokkal, akik csak felnőtt korukban találkozhattak az online kommunikációs lehetőségekkel.

\section{Generációk ${ }^{1}$}

Az információs társadalom az elmúlt évtizedekben a szemünk előtt alakult ki, köszönhetően az infokommunikációs eszközök rohamos fejlődésének. Ezekhez az új kapcsolatteremtési lehetőségekhez különböző módon viszonyulnak az egyének. Ezeket különbözö aspektusból vizsgálhatjuk (pl. iskolázottság, lakóhely), de a legszegmentálhatóbb különbségekkel akkor találkozunk, ha életkor szerint vizsgálódunk. ${ }^{2}$ Ez alapján 6 élő generációt különböztetünk meg, melyek között az átmenet természetesen folyamatos.

Veteránok: az 1928 és 1945 között születettek tartoznak ebbe a csoportba, ők találkoztak/találkoznak legidősebb korban az internetes kommunikáció lehetőségeivel. Akkor nőttek fel, amikor még a telefonvonalak kiépítése lassú ütemben zajlott, így legtöbbjük számára gyerekkorban valós idejü, kétirányú kommunikáció kizárólag akkor volt kivitelezhető, ha fizikailag egy helyen tartózkodtak a felek. Többnyire nehezen, vagy egyáltalán nem használnak online eszközöket kapcsolattartásra, félnek a számukra „ismeretlen” közegtől, és a hagyományos csatornákat részesítik előnyben.

Baby boomerek: ebbe a generációba azokat soroljuk, akik 1946 és 1964 között születtek. Ök már érdeklődőbbek a modern eszközök iránt, kevésbé tartanak tőlük. Ez leginkább annak köszönhetö, hogy az utánuk következő korosztály már aktívan használja ezeket az eszközöket, így ez a generáció a gyermekei révén már testközelből szemlélheti, hogyan müködik az online kommunikáció. Érdeklődés esetén akár azonnal ki is tudja próbálni, van segítsége a lehetőségek megismerésében és a használat elsajátításában. Sokan lelkes online tartalomfo-

${ }^{1}$ Tarné Éder Marianna: Generációk - ,árkok”, szakadékok. http://tarmarianna.blogspot.hu/[-] 2012/03/generaciok-arkok-szakadekok.html '(2016. augusztus 15.)

${ }^{2}$ Vincze Anikó: Generációk az információs társadalomban. = Belvedere Meridionale, 25. évf. 2013. 3. sz. 97-116. p. 
gyasztókká válnak, azonban a veszélyekre kevésbé gondolnak, könnyedén megadják például bankkártyaadataikat.

X generáció: az 1965 és 1979 között született „karrierista nemzedék” számára munkájuk miatt már elkerülhetetlen, hogy használják az online kommunikáció eszközeit, de kapcsolattartás terén továbbra is előnyben részesítik a személyes kontaktust.

Y generáció: a tanulmány szempontjából a leglényegesebb generáció, mert ők a jelenlegi egyetemista nemzedék, az 1980 és 1994 között születettek. Náluk már gyerek- vagy fiatalkorban megjelent az online kommunikáció, így hasonló (vagy jelentősebb) szerepet kap életükben, mint a hagyományos kapcsolattartási formák. Minden információhoz azonnal szeretnének hozzájutni. Alapvető kapcsolattartási formának tekintik a netes lehetőségeket, de ezt még helyhez kötöttebben élik meg, például előnyben részesítik az asztali eszközöket.

Z generáció: az Y generációhoz képest kisebb számban, de már ők is átlépték a felsőoktatási intézmények küszöbét, hiszen az 1995-2010 között született fiatalokról van szó. Ök azok, akik már úgy nőttek fel, hogy számukra az internet ugyanolyan alapvető „közmü”, mint a gáz- vagy a vízszolgáltatás. „Digitális bennszülötteknek" is szokás őket nevezni. Számukra az offline lét gyakorlatilag elképzelhetetlen, előnyben részesítik a mobileszközöket, melyekkel bárhol a világban azonnal kapcsolatba léphetnek a meglehetősen nagy - ugyanakkor felületes - baráti köreikkel. A szimultán online és „,valóságos” létnek köszönhetöen jók figyelemmegosztásban, ugyanakkor kevésbé képesek egy-egy tevékenységben alaposabban elmélyülni. Ebből a generációból sokan netfüggővé válnak/ váltak, akik, hasonlóan egy szenvedélybetegségben szenvedőhöz, képtelenek szüneteltetni a közösségi oldalak használatát.

Alfa generáció: témámat tekintve ők még nem érintettek, de fontos megemlíteni a 2010 után születetteket is. Ők már azelött elkezdik használni az online kommunikációs eszközöket, mielőtt például írni vagy olvasni megtanulnának.

Áttekintve az egyes generációk általános jellemzőit, megállapítható, hogy más a hozzáállásuk az online kommunikációs eszközökhöz. Kisebb-nagyobb mértékben már minden generáció használja ezeket a lehetöségeket, de másképp kell kommunikálni velük ezeken a csatornákon, ha azt akarjuk, az egyes nemzedékeket elérjék a nekik szánt üzenetek.

A továbbiakban elsősorban az ELTE Egyetemi Könyvtár tapasztalatain keresztül azt fogom bemutatni, hogy az Y generációval milyen platformokon célszerü kommunikálnunk a közösségi médián keresztül. Fontos hangsúlyozni, hogy az említett példákon túl az Egyetemi Könyvtár más típusú-tartalmú bejegyzéseket is közzétesz, melyekkel más korcsoportokat céloz, de ez most nem témája jelen írásnak. 


\section{Facebook $^{3}$}

Első helyen nem is lehetne mással kezdeni, mint a legtöbb felhasználóval rendelkezö közösségi oldallal. Az Y generáció többsége már évek óta jelen van ezen a felületen, napi kommunikációjuk jelentős részét bonyolítják itt, legyen szó akár a saját magukkal kapcsolatos bejegyzések közzétételéről vagy csetelésről. ${ }^{4}$ A könyvtárak jelentős hányada is képviselteti magát (legalább ezen az egy) közösségi oldalon. ${ }^{5}$ Nézzük meg, tapasztalataink alapján milyen alapvető praktikákat célszerü szem előtt tartani, ha az egyetemista korosztályt szeretnénk elérni! Egyetlen mérőszámunk, amit használni tudunk a bejegyzéseink hatékonyságával kapcsolatban, a kiváltott interakció mértéke: tehát hányan reagálnak rá például lájkolással vagy hozzászólással, azonban itt nincs lehetőségünk a kor szerinti megoszlást figyelni. Követöink kétharmada tartozik az Y és X generáció tagjai közé, ezért a levont következtetések nem feleltethetők meg kizárólag a fiatal generációk használati szokásainak, de mindenképp irányadók lehetnek abban a tekintetben, hogy milyen szempontokat érdemes szem előtt tartani bejegyzések közzétételénél, hogy ebből a korosztályból is minél több visszajelzést váltsanak ki.

Mikor posztoljunk? Tapasztalataink szerint több okból is a kora esti órákban legcélszerübb kitenni a bejegyzéseket. Ilyenkor a más Facebook-oldalak által publikált „üzleti” bejegyzésekből már kevesebb van, így nagyobb eséllyel jelenik meg posztunk követőinknél. Továbbá látogatási statisztikáink is egyértelmüen mutatják, hogy ebben az időszakban a legmagasabb a bejelentkezett követők száma, így több személytől várhatunk azonnali reakciót bejegyzéseinkre.

Érdemes-e hétvégén posztolni? Igen! Erre részben az előző pontban találjuk a magyarázatot. Hétvégén, szabadnapokon kevesebb a más oldalak által publikált poszt, így nagyobb eséllyel jelenik meg a mi bejegyzésünk a követőknél.

Milyen típusú bejegyzéseket tegyünk közzé? Három típus emelhető ki, amik általában magasabb reakciószámot érnek el a hagyományos, szöveges bejegyzéseknél: a fényképek, a videók és a kérdések.

Milyen hosszú legyen egy Facebook-poszt? Minden tartalomhoz - még képekhez is - illik szöveget írni. Ez viszont legyen minél rövidebb, lényegre törőbb, lehetőleg 50, maximum 100 karakter hosszú, mert az ennél hosszabb szövegü bejegyzések kevesebb interakciót váltanak ki a fiatalok körében. Saját ismerősi körömben is tapasztalom, hogy ebböl a korosztályból sokan úgy gördítik végig az üzenőfalukat, hogy egy-egy bejegyzésre körülbelül 1 másodpercet szánnak, és ez alapján döntik el, hogy lájkolják-e vagy sem, majd görgetnek is tovább. Ennyi időbe nem fér bele hosszú szövegek elolvasása.

${ }^{3}$ Elérhetö: http://facebook.com.

${ }^{4}$ Pótó Zsuzsanna: Közösségi kapcsolatok a virtuális térben - a Facebook-használat statisztikai elemzése. $=$ Acta Sociologica: Pécsi Szociológiai Szemle, 5. évf. 2012. 1. sz. 151-160. p.

${ }^{5}$ Fodor János: A megosztó hivatás. Könyvtári jelenlét a Facebook közösségi oldalon 2013/2014ben. = Tudományos és Müszaki Tájékoztatás, 61. évf. 2014. 7-8. sz. 275-295. p. 
Az alábbiakban áttekintem, hogy milyen tartalmú bejegyzések azok, melyeket tapasztalataink szerint könyvtárként közzétehetünk, és kiválthatjuk vele a fiatalok tetszését.

a) „Színfalak mögötti” fényképes bejegyzések, illetve azok a fotók, melyek olyan részről örökítik meg a könyvtárt, amire a látogatónak nincs lehetősége. Példaként meg lehet említeni az Egyetemi Könyvtár 2016. augusztus 26-i bejegyzését, mely a könyvtárépület tetőjéről mutatja meg a Gellért-hegyet, úgy, hogy a könyvtár kupolája is látszik rajta, illetve a 2016. május 26-i bejegyzést, ahol az olvasóteremben jelenlévők a napfénytetőn keresztül lettek lefényképezve.

b) Fontos a bejegyzéseinkkel azt is tükrözni, hogy „messzebb is látunk az orrunknál", könyvtár esetében a falainknál. Ezzel közelebb kerülhetünk a követőinkhez, hiszen látják, hogy nemcsak a munka megszállottjai dolgoznak a könyvtárakban, hanem ugyanolyan emberek, mint bárki más, akik figyelnek a környezetükre is. 2016. május 20 -án például a főigazgatói szoba ablakából tökéletesen megfigyelhető varjúcsaládról tettünk ki fényképet.

c) Bár ez a korosztály kevésbé nyitott kulturális tartalmakra, megfelelő tálalással az ilyen jellegü bejegyzéseket is el tudjuk juttatni hozzájuk. Ha például idézetet akarunk közzétenni, azt ne egyszerủ szöveges bejegyzésként tegyük, hanem helyezzük rá egy figyelemfelkeltő fényképre, így kevesebben fognak átgörgetni rajta.

d) Már többször említésre kerültek a fényképek, azonban azt is nagyon fontos hangsúlyozni ezekkel kapcsolatban, hogy minél jobb minőségü képeket tegyünk közzé. Rossz minőségü, nehezen kivehető tartalmú bejegyzésekkel nemhogy nem szerezhetünk lájkokat, akár még meglévő követőink közül is veszíthetünk.

e) Olykor a könyvtárak is élhetnek a tipikus lájkvadász bejegyzéssel: ha a könyvtári témájú bejegyzésünkkel kapcsolatba hozható kisgyermek vagy kisállat, érdemes fényképet posztolnunk ezekről. Az ilyen „cukiságok” jellemzően magas reakciószámot hoznak.

f) Célszerủ odafigyelni az aktuális online őrületekre is, melyek sokszor csak pár napig tartanak, ezért ajánlatos gyorsan reagálni rájuk. Például néhány hónapja a Pokemon Go nevezetủ mobiltelefonos alkalmazással összefüggésben az Egyetemi Könyvtárból is posztoltunk „Pokemont” 2016. július 21-én.

g) Humoros bejegyzések is helyt kaphatnak könyvtárak Facebook-oldalain, például mémek felhasználásával, melyeket a könyvtárral kapcsolatba hozható tartalommal töltünk meg. 2015. december 18-án Batman és Robin vitatkozott kicsit a könyvtárakról az Egyetemi Könyvtár Facebook-oldalán.

h) Magas reakciószámot hozhat az is, ha a Facebook egyes újításait az elsők között próbáljuk ki. 2016. július 13-án a pár nappal korábban elérhetővé vált funkció, a 360 fokos gömbpanoráma lehetőségének alkalmazásával fénykép formájában lehetett körülnézni az olvasótermünkben. 
i) Mivel könyvtárakkal meglehetősen sok téma összefüggésbe hozható, így akár egy-egy aktuális világeseményről is tudósíthatunk. Ebben az Országos Széchényi Könyvtár jeleskedett az idei olimpiai időszak alatt. Az elsők között tudósítottak a magyar érmekről, melyeket a követőik kifejezetten magas számú lájkkal és megosztással értékeltek.

A bejegyzések tartalmán túl fontos odafigyelni más tevékenységekre is, ha könyvtárként Facebook-oldalt üzemeltetünk. Tartsuk naprakészen adatlapunkat, hiszen nagyon sokan (például az Y generáció tagjai) elsődlegesen innen tájékozódnak, és csak egy második lépés a könyvtár hivatalos honlapjának felkeresése.

Nagyon fontos az is, hogy egy bejegyzéssel nem csak addig vannak tennivalóink, ameddig közzétesszük. Amennyiben hozzászólás érkezik a posztunkhoz, illik arra reagálni. Ugyanez a teendő a privát üzenetekkel is, melyekre minél gyorsabban kell válaszolnunk, hiszen a Facebook ez alapján kategorizálja oldalunkat. Ha a „Gyors válasz” besorolást kapjuk, akkor nagyobb eséllyel számíthatunk megkeresésre ezen a csatornán keresztül is.

Bár most kifejezetten az Y generáció felöl közelítve tettem javaslatot a Facebook-bejegyzések tartalmával kapcsolatban, azonban általánosságban szem elött tartandó elv, hogy ne csak egyetlen felhasználói körnek posztoljuk. Ha a követőink között idősebbek is vannak, fontos, hogy számukra is biztosítsunk releváns tartalmakat. A kor mellett érdemes odafigyelni még a nyelvre is. Amennyiben magas az idegen nyelvü követők aránya, bejegyzéseinket célszerü a magyar mellett legalább angolul is közzétenni. Ehhez már remek technikai megoldást kínál a közösségi oldal, egy bejegyzéshez több nyelven tudunk szöveget írni, és minden felhasználó csak a saját beállított nyelvének megfelelő verziót látja.

\section{Instagram $^{6}$}

Az Y generáció szempontjából a második legjelentősebb közösségi felület mára az Instagram lett. Ez egy eredetileg kizárólag mobiltelefonokra szánt képmegosztó szolgáltatás, mára azonban néhány funkciója már számítógépes böngészővel is elérhető. Előszeretettel használják a fiatalok képmegosztásra, hiszen a Facebookkal ellentétben itt kevésbé vannak jelen még szüleik, így olyan képeket is közzétesznek itt, amit Facebookon már nem feltétlenül „mernének”. Az Instagram közösségi elve szerint nem ismerösöket, hanem követőket lehet gyüjteni, illetve követővé válhatunk, ami nem feltételezi a személyes ismeretséget. Ez szintén vonzó szempont a fiatalok számára, akik szívesen kezdeményeznek kommunikációt számukra ismeretlen személyekkel is.

Az Instagram alkalmazását össze lehet kötni Facebook-oldalunkkal is, így azonnal megjelenhet az ott feltöltött bejegyzésünk a Facebookon. (Az Instagram

${ }^{6}$ Elérhető: http://instagram.com. 
a Facebook tulajdona, így az azon keresztül megosztott bejegyzéseket a rendszer előnyben részesíti más hasonló alkalmazásokkal szemben.)

Mivel kifejezetten fényképmegosztó szolgáltatásról van szó, különösen érdemes odafigyelni a fényképek minőségére. Az alkalmazás lehetőséget kínál megosztás előtt a képek szerkesztésére, javítására, különböző effektekkel való „feldobására”. Amennyiben lehetőségünk van rá, négyzet vagy álló képeket posztoljunk, mert a felhasználók többsége álló képernyőn nézi mobiltelefonján keresztül, így egy fekvő kép nagyon apró méretben jelenik meg.

Jellemzően az Y generáció használja ezt a szolgáltatást, az ELTE Egyetemi Könyvtár követőinek háromnegyede ebbe a korosztályba sorolható.

\section{Facebook vs. Instagram}

Felmerülhet a kérdés, melyik szolgáltatással érhetünk el több felhasználót, melyiken válthatunk ki több aktivitást. Az Egyetemi Könyvtár tapasztalatai alapján egyértelmüen kijelenthető, hogy az Instagram vezet e téren. Az ide feltöltött bejegyzések átlagosan a követők kétharmadát érték el, és az elért felhasználók 10-15 százaléka reagált is a bejegyzésekre. Ezzel szemben a Facebookra feltöltött bejegyzéseket mindössze a követők harmada látta, reakciót pedig az elért felhasználók 1-3 százalékából váltottak ki.

\begin{tabular}{|l|c|c|}
\hline & Facebook & Instagram \\
\hline Követök száma & 3271 & 1242 \\
\hline Elért felhasználók száma & 1059 & 867 \\
\hline Elért felhasználók aránya a követőszámhoz képes & $32,4 \%$ & $69,8 \%$ \\
\hline Reakciók/lájkok száma & 42 & 168 \\
\hline Reakciók/lájkok aránya a követőszámhoz képes & $1,3 \%$ & $13,5 \%$ \\
\hline
\end{tabular}

1. táblázat. Egyidőben posztolt, ugyanazon fénykép által kiváltott reakciók a két oldalon

\section{További közösségi oldalak}

Talán többek is egy másik közösségi oldalt, a Twittert ${ }^{7}$ várták második helyre az Instagram helyett. Azonban az Egyetemi Könyvtár tapasztalatai alapján Magyarországon a Twitter kevésbé népszerü, a kitett tweet-ekre elenyésző számban érkezik visszajelzés, s azok is jellemzően felhasználóink helyett más könyvtáraktól.

Bár elsődlegesen nem közösségi oldal, de említést érdemel még a YouTube ${ }^{8}$ is, ahol szintén képviselteti magát néhány könyvtár egy-egy fiókkal. Azonban a tapasztalat az, hogy - elsősorban emberi erőforrás hiánya miatt -, nincs kapacitás

\footnotetext{
${ }^{7}$ Elérhetö: http://twitter.com.

${ }^{8}$ Elérhetö: http://youtube.com.
} 
a könyvtárakban folyamatos videóanyag elöállítására, ezért ritkán frissülnek ezek a YouTube-csatornák.

\section{Könyvtári weboldal}

Ha online jelenlétről beszélünk, nem szabad megfeledkezni a könyvtárak saját weboldaláról sem, hiszen ez is egy olyan felület, ahol sok esetben elsőként tájékozódnak a különböző szolgáltatásokról az egyetemisták. Bizonyos szempontból ez egy nehezebb terep, mert itt sokkal nagyobb kihívás differenciált tartalmat létrehozni, mégis minden számára releváns információt ugyanúgy meg kell találnia rajta egy fiatalnak, mint egy idősebb látogatónak. Ezt elsősorban azzal tudjuk biztosítani, hogy az egyes tartalmakat többféle szempont alapján is elérhetővé tesszük.

Ebben a szellemben készült el az ELTE új könyvtári weboldala, melyet a hallgatók a 2016-2017-es tanév őszi félévének elején kezdhettek el használni. Az Eötvös Loránd Tudományegyetem széttagolt könyvtári hálózattal rendelkezik, csaknem 50 kisebb-nagyobb könyvtár összessége alkotja az Egyetemi Könyvtári Szolgálatot, melynek első honlapja 2011-ben készült el. Az akkori könyvtárközpontú szemlélet kevésbé alkalmazkodott a fiatalok gondolkodásmódjához, hiszen először mindig egy könyvtárat kellett kiválasztaniuk, ha az elérhető szolgáltatásokról akartak tájékozódni. Az Y generáció kevésbé helyhez kötött, őket inkább az érdekli, hogy a számukra éppen szükséges szolgáltatást hol tudják a leggyorsabban, legkönnyebben megközelíthetően igénybe venni. Ezt a gondolkodásmódot követve - de megtartva a korábbi felépítésre jellemzö feltérképezés lehetőségét is - jött létre egy szolgáltatásközpontú weboldal. A kiindulópont a szolgáltatás és az elérhetőség ellenőrzése után ajánlja fel azokat a „szolgáltatási helyeket”, ahol azt igénybe lehet venni. A helymeghatározással való támogatásnak köszönhetően a felhasználó azt az információt is azonnal látja, hogy a szolgáltatás legközelebb hol vehető igénybe, és akár azonnali útvonaltervezésre is van lehetöség.

További, elsősorban fiatalokat célzó szolgáltatás, hogy az ELTE tanulmányi rendszerében használt azonosítóval (Neptun-kód) bejelentkezve már a könyvtári honlapon figyelmeztetéseket jelenítünk meg, ha az olvasónak például lejáró kölcsönzése vagy készpénztartozása van. Ehhez korábban be kellett jelentkezni a teljesen egyedi azonosítást használó online katalógusba. Ha valaki - például saját gépén - bejelentkezve marad, és bármilyen ügyből kifolyólag meglátogatja az Egyetemi Könyvtári Szolgálat weboldalát, akkor automatikusan megjelennek neki ezek a fontos figyelmeztetések.

Fontos egy weboldalnál az is, hogy mobileszközökről is könnyen használható legyen. Ez a témám szempontjából azért is kiemelendő, mert a fiatal generáció előszeretettel használja ezeket az eszközöket internetezésre. A mobilon 
is használható weboldalaknak alapesetben két jól elkülöníthető fajtája van. Az egyik a reszponzív honlapok, melyek képernyőméret függvényében automatikusan átrendeződnek, általában egy hosszú oszlopszerü elrendezésre okostelefonos képernyőn. A második lehetőség egy különálló mobil weboldal létrehozása, melynek a felülete kifejezetten mobileszközre készül, ezért ez kényelmesebb használhatóságot biztosít, mint egy automatikus átrendezés. Ugyanakkor hátránya, hogy külön kell „gondozni”, hiszen különálló oldalról van szó.

Az Egyetemi Könyvtári Szolgálat új honlapjánál ezt a két megközelítést vegyítettük, amely kényelmes használhatóság mellett nem igényel külön adminisztrációt. Ezt úgy értük el, hogy a különálló, kifejezetten mobileszközökre szánt jQuery Mobile felhasználói felülethez a tartalmi elemeket a normál holnapot kezelő Drupal tartalomkezelő rendszer adatbázisából közvetlenül nyerjük ki, így nem szükséges két helyen frissíteni a tartalmakat.

\section{Összegzés}

Bár a könyvtárakat sokan ,múltbeli” intézményeknek tekintik, azonban ezzel a sztereotípiával nem szabad azonosulni. Meg kell keresni azokat a lehetőségeket, ahol meg tudjuk mutatni, hogy a könyvtárak tartják a lépést az idővel a szolgáltatásaik terén. Erre nagyon jó felületet biztosítanak a közösségi oldalak és saját honlapjaik, annál is inkább, mivel az Y és az azt követő generációkkal elsődlegesen ezeken a felületen tudjuk közvetlenül felvenni a kapcsolatot, azzal a céllal, hogy a jövőben szolgáltatásaink felhasználójává váljanak.

\section{Rezümé}

Napjainkban az egyetemisták túlnyomó többségét a Y generáció tagjai, vagyis az 1980 és 1994 között született fiatalok teszik ki. Ök már úgy nőttek fel, hogy életük szerves részévé vált az online kommunikáció, amit a könyvtáraknak is figyelembe kell venni, ha meg akarják szólítani őket. Ez a korosztály mindent „most és azonnal” akar, lehetőleg úgy, hogy ne kelljen elmozdulni a monitor/kijelző elől. Elsődleges információforrásuk az internet, ami alatt nemcsak az online keresőket, hanem az online kapcsolattartás által biztosított lehetőségeket is értem.

Magyarországon a legnépszerúbb közösségi szolgáltatások, ahol könyvtárak is jelen lehetnek, a Facebook és az Instagram. Ha felsőoktatási könyvtárként azt akarjuk, hogy a fiatalok tudomást szerezzenek rólunk, egyre lényegesebb, hogy ezeken a felületeken (is) jelen legyünk. Mindegyiknek megvannak a sajátosságai, amelyekre érdemes odafigyelni, ha könyvtári profilokat üzemeltetünk. Nem szabad szinkronban ugyanazokat a tartalmakat közzétenni minden közösségi oldalon, mivel más felhasználói réteg használja az egyes szolgáltatásokat. Általánosságban elmondható, hogy ha az Y generációt akarjuk elérni, akkor törekedni kell a rövid és tömör tartalmakra, melyeket vizuális elemekkel is kiegészítünk. 


\section{How to Communicate with Generation Y on Online Platforms?}

Today the vast majority of the students are the members of Generation Y, people born between 1980 and 1994. They grew up with online communication in their lives, and a library that would like to address them should take this into consideration. This generation has a "now and immediately" attitude, and they try to avoid to move from the screen. The Internet is their primary source of information, which means not only the online search engines, but also the online social media.

In Hungary the most popular social media websites where libraries can be present are Facebook and Instagram. If we, as a university library want young people to become aware of us, it's very important for us to use these platforms, too. Each platform has its own characteristics, which are worth paying attention to when creating the profile of the library. Different contents should be published on different social sites as different groups of users use them. Generally speaking, if we want to connect to the Y generation, we must focus on the shortness and conciseness of the message, and add some visual content, too.

GARAMVÖLGYI LÁSZLÓ

informatikus könyvtáros

ELTE Eötvös Loránd Tudományegyetem Egyetemi Könyvtár 



\section{Dezideráta szolgáltatás bevezetése az ELTE Egyetemi Könyvárban}

\section{Szemléletváltás}

A dezideráta szolgáltatás bevezetése abban a formában új az Egyetemi Könyvtárban, ahogyan az előadásban elhangzott. Fejlesztés alatt álló szolgáltatásról van szó, melyet idén tervezünk bevezetni és a felhasználókkal is megismertetni. A szolgáltatás olvasók felé kommunikált nevére még nem született döntés, ennek véglegesítése folyamatban van.

A könyvtárban Szerzeményezési Bizottság müködik, melynek tagjai több osztály munkatársai közül kerülnek ki, biztosítva ezzel többféle szemlélet képviseletét mind olvasói, mind az állomány oldaláról nézve. A Szerzeményi Bizottság dönt az egyes dokumentumok esetén azok beszerzéséröl, arról, hogy hány példányban vegyük meg, és arról, hogy az melyik gyüjteményi helyre kerül.

Korábban is volt lehetősége az olvasóknak beszerzési kérést eljuttatni a könyvtár felé. Ennek leggyakoribb formái a szóbeli közlés, az e-mailben küldött, telefonon leadott, illetve a WebOPAC-on található, „Ha kérdése van, írjon!” rész kitöltésével küldött kérés voltak.

Az igények leginkább a Közönségszolgálati Osztályra érkeztek, kisebb részben a Gyüjteményszervező Osztályra. A kérések kezelését az eljárás lépéseinek, időtartamának és a küldött válaszoknak a különbözősége jellemezte.

Az új szolgáltatás bevezetése előtt megvizsgáltuk a dezideráta kérések leadásának hazai és a nemzetközi gyakorlatát. A skála viszonylag széles, a füzetbe írt kérésektől indulva a DDA (Demand Driven Acquisition = Kérés szerinti gyarapítás) szerinti gyarapításig. Ez utóbbi gyakorlat leginkább az USA-ban és Nyugat-Európában terjedt el. Az olvasók online keresőrendszerben választják ki a beszerzésre szánt dokumentumot, a DDA rekordot betöltik a könyvtár elektronikus katalógusába. A legtöbb könyvtár külön pénzalapot hoz létre a beérkezett kérések teljesítésére, melynek gyors megvalósulását a kiadókkal, kereskedőkkel és a szállítókkal kötött megállapodások, szerződések biztosítják.

A könyvtárunkban korábban leadott kéréseket - cél alapján vizsgálva - két csoportra oszthatjuk. Az egyik rész szerzeményezési javaslatot tett, melynek célja az állomány teljesebbé tétele volt, ekkor az olvasó nem kérte a példányhoz való hozzáférést. A javaslat leadásával felhívta a könyvtár figyelmét újonnan megjelent mủvekre, amelyek megvételével az adott szerző összes könyve meglehetne a könyvtárban, vagy esetleg jelezte, ha egy dokumentumból kevés példányszámmal rendelkezett a könyvtár. 
Másik esetben a leadott kérésnél a gyors beszerzés és a hozzáférés mihamarabbi biztosítása jelent meg igényként. Az ELTE helyi sajátságait figyelembe véve ez utóbbit jelentősen befolyásolta a rendelkezésre álló pénz és a bürokrácia. A közbeszerzési pályázatok hosszú átfutási ideje, az esetleges érvénytelen, majd az ezt követő újbóli pályázat, a költségvetés alakulása, az engedélyek aláírásának hosszú átfutási ideje nem kedvez a gyors beszerzésnek és feldolgozásnak. Ebben az esetben az ELTE hátrányba kerül azokkal a könyvtárakkal és szolgáltatókkal szemben, akik teljesíteni tudják a pár napon belüli hozzáférés követelményét.

A korábbi dezideráta kérés leadásnak eseteit, a hazai és nemzetközi gyakorlatokat, az ELTE sajátosságait megvizsgálva a könyvtár a szemléletváltás mellett döntött. Egyrészt az olvasóinkat hangsúlyozottan szeretnénk bevonni az állomány gyarapításának javaslat szinten történő támogatásába, másrészt a szemléletváltás a könyvtár és a könyvtáros részéről is megjelenik, hiszen eddig a gyarapítás könyvtárosi feladat volt, minimálisan jelent meg külső igény. Ennek alapján a korábbi szerzeményezési gyakorlat kiegészül az olvasói kérések megjelenésével.

Az új folyamat bevezetésének a fentiek mellett célja a folyamatszintủ müködés biztosítása, az egységes eljárás kialakítása, ezzel a párhuzamosságok kiszürése, a hatékonyság növelése, a minőségi szolgáltatás létrehozása és a statisztikák készítésének lehetősége.

\section{A fejlesztés első szakasza: a tervezés}

Elsőként megvizsgáltuk a dezideráta kérés hagyományos menetét, majd az abban rejlő kritikus, fejlesztendő pontokat azonosítva megfogalmaztuk az igényeket, és megvizsgáltuk a rendelkezésre álló erőforrásokat személyi, anyagi és eszköz oldalról is. Egyeztettünk az Aleph integrált könyvtári rendszer magyarországi forgalmazóival, az Ex-Lh Számítástechnikai Kft.-vel a lehetőségekről és a működésről, majd kiválasztottuk a végleges verziót. Ezt követően készítettük el a folyamatvázlatot az új szolgáltatásról.

A tervezéskor meghatároztuk, hogy a fejlesztésnek mind az angol, mind a magyar felületen párhuzamosan kell haladnia a webOPAC-on, és azt is, hogy minden lépést több böngészőből indulva is ellenőrizni kell, hogy a felhasználók megfelelö tartalmat és megjelenítést lássanak.

\section{A fejlesztés második szakasza: Aleph beállítások, levelezés}

Az Aleph módosítások során az első lépés az új gyüjtemény (Dezideráta) és az új példánystátus (Beszerzés alatt) kialakítása és paraméterezése volt. A webOPACon leadott kérések mindegyike a Dezideráta gyüjteménybe kerül, a példánystátusza „Beszerzés alatt” lesz.

Ezután következett a jogosultságok beállítása. Olvasói oldalról minden olvasói státusznak engedélyeztük a dezideráta kérés leadásának lehetőségét. Egy- 
ségesen adtuk meg a beküldhető kérések számát, amit lehetőség van csökkenteni vagy emelni együttesen vagy olvasói státuszonként is. Példánystátusz és gyüjtemény oldalról is engedélyeztük a kérést.

A kérés során létrejövő rekordba bekerül egy bázis kód, melynek funkciója az OAI-PMH (Open Archives Initiative Protocol for Metadata Harvesting) küldés tiltása és a listázási lehetőség biztosítása.

Az új folyamathoz kapcsolódóan központi e-mail címet hoztunk létre, melyen keresztül folyamatosan biztosítható a beérkezett kérések és a szolgáltatással kapcsolatos levelezés követése.

\section{A fejlesztés harmadik szakasza: webOPAC}

Ebben a szakaszban történt meg a dezideráta kérés ürlapjának kialakítása és a „Ha kérdése van, írjon!” rész módosítása a webOPAC-ban.

A „Ha kérdése van, írjon!” részen keresztül bejelentkezett olvasóként és vendégként is lehetőség van a könyvtáraknak üzenetet küldeni. Korábban itt is jeleztük a felhasználóknak, hogy a beszerzési kéréseiket elküldhetik a könyvtár felé. Ezt a részt a felvezető szövegből töröltük.

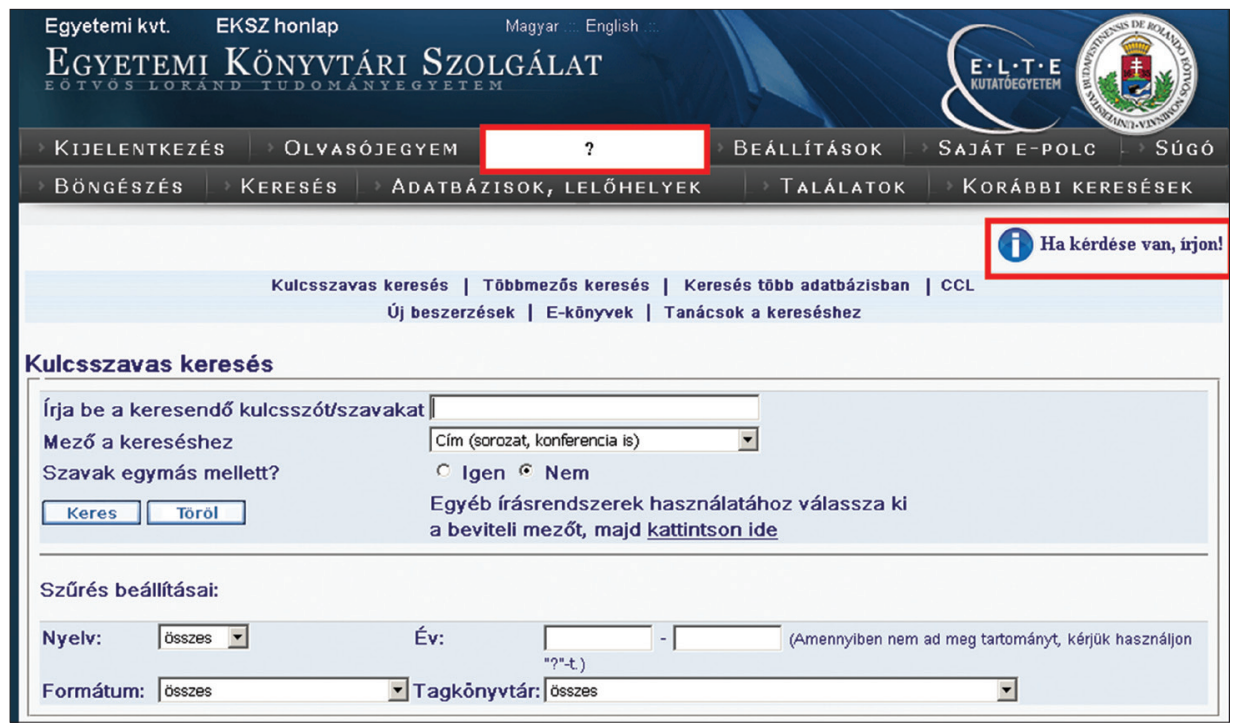

1. ábra. WebOPAC, dezideráta kérés helye és a Ha kérdése van, írjon! felület ${ }^{1}$

A webOPAC ürlap első részében tájékoztatjuk az olvasókat a szolgáltatásról, annak céljáról, menetéről, a visszajelzés formájáról.

${ }^{1}$ Forrás: http://opac.elte.hu/F/HI59CV5MIDSJHTTPSRBT2PTST41GQ9TEUSBJ3KBTLVUJ2SUB4I-31314? func=find-b-0 (2016. augusztus 31.) 
Mivel az Egyetemi Könyvtár teljes állománya nem kereshető a webOPACban, ezért az ürlap első részében kaptak helyet a digitalizált katalógusok linkjei. Megtalálhatók itt az alapkatalógus, a tárgyszókatalógus, az ETO katalógus és a Kézirat- és Ritkaságtár katalógusai. Ezen linkek bármelyikére kattintva az olvasónak lehetősége van ellenőrizni, hogy a beszerzésre javasolt dokumentum a könyvtár állományában megtalálható-e.

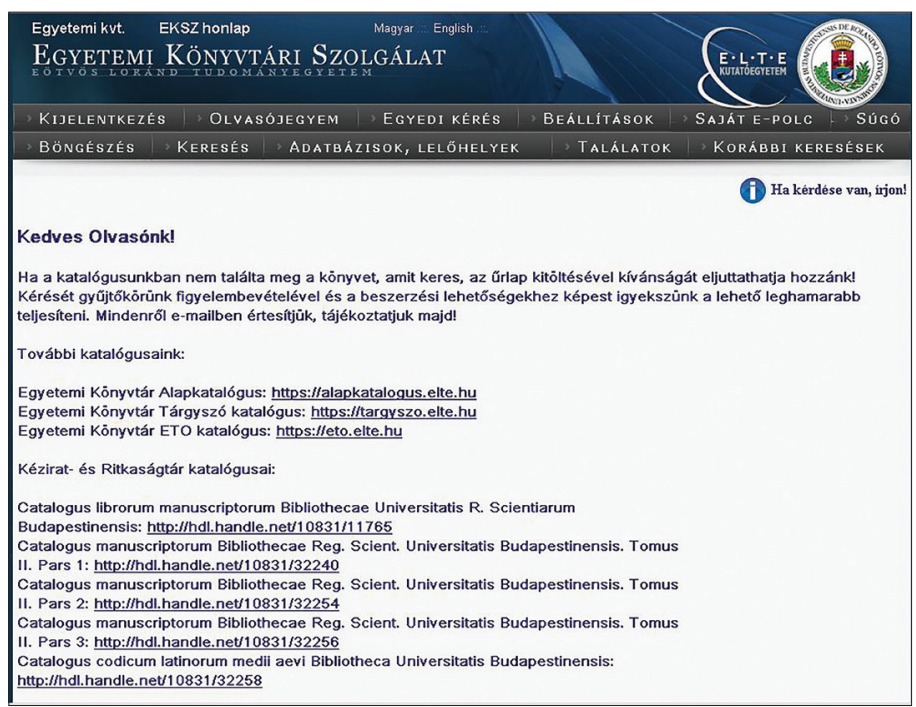

2. ábra. WebOPAC, a dezideráta kérés olvasói tájékoztatója²

A webOPAC ürlap második részében találhatók a kérésleadás kitöltendő mezői. Az ürlap kialakításakor arra törekedtünk, hogy a felület legyen átlátható, ne legyenek felesleges mezők, és olyan adatokat kérjünk a dokumentumról, amelyek egyértelmüsítik a kérést. A mezők közül a dokumentum címe és az olvasó e-mail címe kötelező mező. Ezek kitöltése nélkül a kérés nem indítható, az ürlap alján található „Rendben” gomb nem aktív.

A szerző és a kiadási év mező kitöltése nem kötelező, de segítséget nyújt a dokumentum azonosításához. Az ürlap végén található „Egyéb” nevü szabad szöveges mezőnél lehetőség van hosszabb megjegyzést füzni a kéréshez vagy akár linket beilleszteni, ami szintén segítheti a dokumentum egyértelmủ megtalálását. Itt írhatja meg az olvasó azt is, hogy milyen céllal kéri a dokumentum beszerzését.

Ha a kötelező mezők kitöltése megtörtént, akkor a „Rendben” gomb aktív lesz, ennek megnyomásával indítható a kérés. Beépítésre került egy captcha, melynek kitöltése után a kérés véglegesíthetö.

${ }^{2}$ Forrás: http://opac.elte.hu/F/HI59CV5MIDSJHTTPSRBT2PTST41GQ9TEUSBJ3KBTLVUJ2SUB4I-32033? func=new-record-0 (2016.augusztus 31.) 


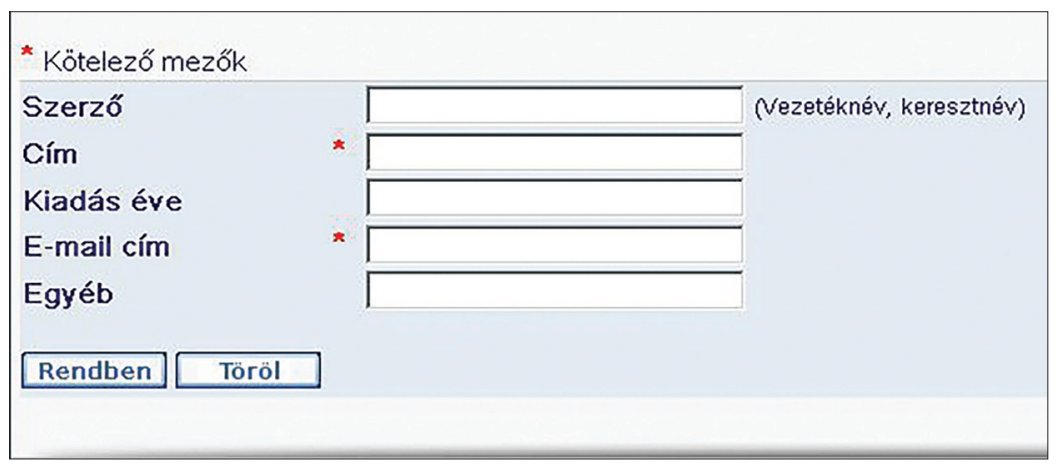

3. ábra. WebOPAC, a dezideráta kérés ürlapja ${ }^{3}$

A dezideráta kérés leadásához a felhasználónak be kell lépnie a webOPAC-ba. A most még deziderátának hívott gomb megnyomása után az ürlap kitöltése, a „Rendben” gomb megnyomása, a captcha kitöltése és a kérés véglegesítése következik. Ezzel létrejön egy rekord és példány az Aleph-ben, elöjegyzés kerül a példányra az olvasó nevével.

\section{Az olvasó tájékoztatása}

Az olvasó kap egy visszajelző e-mailt a kérésről, melyben tájékoztatjuk arról, hogy az üzenete megérkezett hozzánk, azt elbíráljuk és válaszolunk hamarosan, valamint a levél tartalmazza a kéréskor kitöltött mező adatait, így az olvasó láthatja, hogy mely kérésről van szó. Ugyanezt a levelet megkapja a könyvtár is. A könyvtáros feladata ellenőrizni, hogy a kért dokumentum a könyvtár állományában megtalálható-e. A lehetséges esetek:

a) A kért dokumentum megtalálható a webOPAC-ban az Egyetemi Könyvtár hozzáférhető vagy kölcsönzött példányaként.

b) A kért dokumentum megtalálható a webOPAC-ban egy másik ELTE-s tagkönyvtár hozzáférhető vagy kölcsönzött példányaként.

c) A kért dokumentum megtalálható valamely webOPAC-on kívüli katalógusban az Egyetemi Könyvtár példányaként.

d) A kért dokumentum nem található meg egyik katalógusban sem.

Az első két esetben az olvasót tájékoztatni kell a dokumentum meglétéről, a lelőhelyről, a hozzáférés módjáról, idejéről, illetve az előjegyzés lehetőségéről.

Előfordulhat, hogy a példány kötészeten van, esetleg külső raktárban. Az ezekhez kapcsolódó egyéb információkat (mikorra kötik be a dokumentumot, mikor van szállítás a külső raktárból) is el kell juttatni az olvasóhoz.

${ }^{3}$ Forrás: http://opac.elte.hu/F/HI59CV5MIDSJHTTPSRBT2PTST41GQ9TEUSBJ3KBTLVUJ2SUB4I-32033? func=new-record-0 (2016.augusztus 31.) 
A harmadik esetben az olvasó informálását megelőzi a dokumentum feldolgozása az integrált könyvtári rendszerben, és a gyüjteményi helyre irányítás.

A negyedik esetben a kérés a beszerzéssel foglalkozó könyvtárosokhoz kerül, akik elsősorban a belső Gyüjtőköri szabályzat és a rendelkezésre álló anyagi források figyelembevételével döntenek kiadvány megvételéröl.

Ahhoz, hogy az olvasó megkapja a szükséges információkat, szabványleveleket készítettünk, melyek a lehetséges esetekhez kapcsolódva adnak választ az olvasói kérésre. Ezek az alábbiak:

a) A kért dokumentum megvan az Egyetemi Könyvtárban, hozzáférhető.

b) A kért dokumentum megvan az Egyetemi Könyvtárban, de jelenleg nem hozzáférhető (más olvasó kölcsönözte, éppen előjegyezték, kötészeten vagy kiállításon van stb.).

c) A kért dokumentum megvan valamelyik ELTE-s tagkönyvtárban.

d) A kért dokumentum nincs meg az Egyetemi Könyvtárban, de a gyüjtőkörünkbe tartozik és beszerezzük.

e) A kért dokumentum nincs meg az Egyetemi Könyvtárban, nem tartozik a gyüjtőkörünkbe, s ezért nem szerezzük be.

f) A kért dokumentum nincs meg az Egyetemi Könyvtárban, jelenleg nincs forrás a beszerzésre, de amint lehetséges, beszerezzük.

g) A kért dokumentum nincs meg az Egyetemi Könyvtárban, jelenleg nem lehet beszerezni, ha kapható lesz, beszerezzük.

h) A kért dokumentum nincs meg az Egyetemi Könyvtárban, nem gyüjtőkörünk, de továbbítottuk a kérést annak az ELTE-s tag könyvtárnak, amelyhez témája alapján tartozik. (Ebben az esetben az érintett könyvtárat is értesíteni kell a kérésröl.)

i) A megadott adatok alapján nem tudtuk a kért dokumentumot azonosítani, pontosítást, további adatokat kérünk.

Amennyiben az a döntés születik, hogy a dokumentumot a könyvtár beszerzi, akkor annak beérkezése, feldolgozása és gyüjteményi helyre szállítása után kap az olvasó tájékoztatást a dokumentumhoz való hozzáférés lehetőségéről.

A feldolgozáskor a könyvtáros dönt a kérés során létrejött rekord és példány sorsáról. Ha talál a webOPAC-ban olyan rekordot, amely teljes, akkor a létrejött rekordot és a hozzá kapcsolódó példányt törli, és a meglévő rekordhoz kapcsolja az új példányt. Ha nem talál meglévő egyéb rekordot, akkor a kérés során létrejött rekordot és példányt egészíti ki. Lehetőség van a teljes rekord más adatbázisból való átemelésére, ekkor a kéréssel létrejött rekordot és példányt törölni kell.

\section{A szolgáltatás véglegesítése, statisztika}

A szolgáltatás véglegesítése, az egyes osztályok feladatának meghatározása folyamatban van. A feladatok felosztásánál elsődleges cél a hatékonyság kialakí- 
tása és a megfelelő külső és belső kommunikáció biztosítása. Feladattól függően szükséges lehet az Aleph katalogizáló és kölcsönző moduljainak betanítása, mivel a kérés során olvasói és példány oldalról is szükséges módosításokat, törléseket, kiegészítéseket végezni.

A szolgáltatás végleges kialakítása után készül el az ehhez kapcsolódó folyamatleírás mely tartalmazza többek között a folyamathoz szükséges erőforrásokat, a folyamatkategóriát, a vonatkozó szabályozást, a kritikus pontokat, a folyamat leírását, a keletkező és használandó dokumentumokat, a mérési és statisztikai pontokat. Ezt követően készül el a folyamatábra. A folyamat elfogadása és bevezetése után a szolgáltatás eszerint müködik. Idővel szükséges a folyamat felülvizsgálata, ha szükséges, akkor módosítása.

A szolgáltatásról statisztikai lekérdezés végezhető. A tervezett mérési periódus a havi lekérdezés. Ennek során mérjük a beérkezett kérések számát, a döntések milyenségét (beszerezzük, nem szerezzük be), a beszerzések számát, az átfutási időt (a kérés beérkezésétől a dokumentum hozzáférésének biztosításáig), a valamely ELTE-s könyvtárba továbbított kérések számát és azok teljesülését.

A statisztikáról a fenntartó és a karok könyvtárai is tájékoztatást kapnak.

\section{A szolgáltatás kommunikálása}

Az új szolgáltatásról olvasóinkat több formában is értesítjük. A könyvtárba beérkező olvasókat szóban tájékoztatjuk a szolgáltatásról, illetve szórólapot helyezünk el a könyvtár több pontján, az Információs pultnál és az olvasótermekben.

A portálon megjelentetjük a dezideráta szolgáltatás tájékoztatóját. Az olvasóknak küldött e-mailek végére a portálon megjelent hír linkjét bemásoljuk, és ideiglenesen beillesztjük a hamarosan lejáró kölcsönzésekről tájékoztató emlékeztető leveleink végére.

Az ELTE könyvtárosait az IKR hírlevélben és a Könyvtáros hírlevélben értesítjük, melyeket a Kolibri levelezőlistán keresztül küldünk ki.

\section{Rezümé}

A tanulmány a dezideráta szolgáltatás kialakításának folyamatát mutatja be. Kitér az Egyetemi Könyvtár szerzeményezésének és a dezideráta kérés leadásának jelenlegi, valamint új szemléletủ, jövőbeli gyakorlatára, érintve a hazai és a nemzetközi példákat is. Vázolja a fejlesztés során végzett változtatásokat mind az Aleph, mind a webOPAC rendszerre vonatkoztatva, részletezi az olvasói és példány oldalról a létrejött beállításokat. Bemutatja a kialakított dezideráta ürlapot és az olvasói tájékoztatás formáit. Szól a folyamat eddig kialakított lépéseiről olvasói és könyvtári oldalról. Kitér a kérésekhez kapcsolódó egyes esetekre. Részletezi a további feladatokat, a betanítást, a folyamatleírást, a szolgáltatás kommunikálását, valamint a tervezett statisztikai méréseket és az ehhez kapcsolódó fenntartói és könyvtáros tájékoztatást. 


\section{The Introduction of the Deziderata Service in the ELTE University Library}

The presentation shows the introduction process of the desiderata service. It covers the University Library's current practices of acquisition and of submitting desiderata requests as well as the new approaches and future practices, including national and foreign examples. It outlines the changes made in Aleph and in WebOPAC during the development, and details the settings created for both readers and documents. It presents the newly created desiderata application form, its fields and the ways of informing the readers. The presentation describes the steps already taken during the process for both readers and libraries. It presents some cases of requests and provides a template of letters to be sent out for readers. It also specifies additional tasks: taking trainings, working out process descriptions, communicating the service for both readers and librarians, as well as planning the collection of statistical data and providing guidance for librarians and university leaders.

CZINKI-VIETORISZ GABRIELLA informatikus könyvtáros ELTE Eötvös Loránd Tudományegyetem Egyetemi Könyvtár 


\section{Tanulástámogató szolgáltatások a Savaria Egyetemi Központ Könyvtárában}

A Nyugat-magyarországi Egyetem Savaria Egyetemi Központ Könyvtára (jogelőd: Berzsenyi Dániel Főiskola Könyvtára) 2008-tól támogatja a három, később két kar oktatási és tanulási, valamint kutatási tevékenységét. A kis létszámú könyvtár minőségi szakmai ellátásra törekvő munkáját 2007-ben az Év Könyvtára kitüntetéssel ismerték el, 2014-től pedig Minősitett Könyvtár címmel rendelkezik. E címek elnyeréséhez nagyban hozzájárult az a felismerés, hogy szükséges a könyvtári munka folyamatainak átértékelése, az oktatás paradigmaváltásának támogatása, s új irányok meghatározása. A felsőoktatási könyvtárakban ezek a változások a hallgatók módosuló tanulási szokásai miatt gyorsabban zajlanak.

A Savaria Egyetemi Központ Könyvtára (SEK Könyvtára) mint felsőoktatási szakkönyvtár elsősorban az oktatók és hallgatók számára nyújt szolgáltatásokat, de mint a Vas Megyei Pedagógia Intézet jogutód könyvtára a pedagógusok szakkönyvtári ellátását is biztosítja. A regionális szerepkörú könyvtári szolgáltatások mellett rendezvények szervezésével közmüvelődési funkciókat is ellát, amelynek fó célja a leendő hallgatók bevonzása az intézménybe.

Napi tapasztalataink megegyeznek a világ trendjeivel, amelyek szerint a hagyományos, könyvalapú tanulási folyamat digitális környezetbe helyeződik át, ahol a könyvtáraknak is meg kell találniuk a helyüket. A papíralapú, elsősorban könyvdokumentumok helyett az e-alapú tartalmak szolgáltatási környezetét kell kialakítani, alkalmazkodva az új igényekhez.

A felsőoktatás finanszírozási rendszerének kedvezőtlen változásai miatt a SEK Könyvtára törekszik a nyílt forráskódú, ingyenes, közvetlen pénzügyi ráfordítást nem igénylő szoftverek, alkalmazások megismerésére, és a szolgáltatási rendszerünkbe való beillesztésükre. A fejlesztések nagy részét belső és szükös humánerőforrás segítségével kell megvalósítanunk.

A tanulmány bemutatja a SEK Könyvtárában alkalmazott tanulást segító szolgáltatásokat, jó gyakorlatokat, amelyekkel a könyvtárosok a hagyományos könyvtári munka mellett aktívan részt vesznek a tanítási/tanulási folyamatok digitális alapú támogatásában. A használói igényeket figyelembe véve a könyvtárban alkalmazott legfontosabb eszközök, keretrendszerek, internetes szolgáltatások, portálok közül a következők emelendők ki:

1. Podcast videó csomagok

2. Videotorium.hu felsőoktatási videóportál

3. Moodle oktatási keretrendszer 
4. MAHARA e-portfólió keretrendszer

5. Turnitin/Ephorus plágiumkereső szolgáltatás

6. Drupal CMS tartalomkezelö rendszer

7. Digitális dokumentumtárak (NymE Tudástár, Intranet, Google szolgáltatások)

8. Magyar Tudományos Mủvek Tára (MTMT)

A könyvtár igyekszik ezeket az eszközöket funkcionálisan beépíteni a tanulást támogató szolgáltatási rendszerébe. ${ }^{1}$

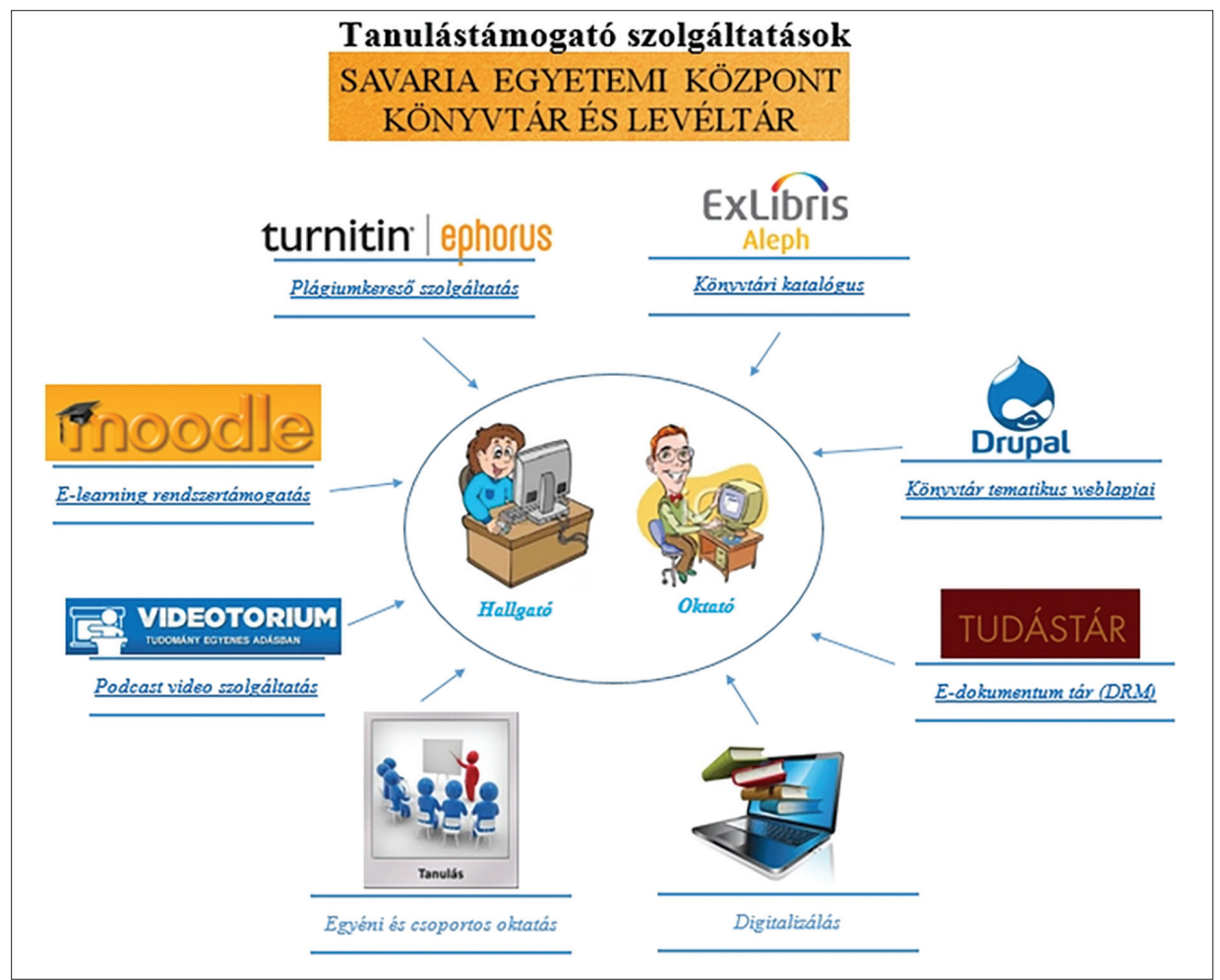

1. ábra. A SEK Könyvtára tanulástámogató szolgáltatási rendszere

\section{Podcast videó csomagok}

Az intézmény jogelődje, a Berzsenyi Dániel Főiskola jó hírnevet szerzett az oktatástechnikai eszközök alkalmazásában (,szombathelyi modell”). ${ }^{2}$ A tanárképzés egyik didaktikai alapeleme volt az 1980-as években a hallgatók tanítási

${ }^{1}$ http://tudastar.nyme.hu/sekkonyvtar/content/tanulastamogato-szolgaltatasi-rendszer (2016. augusztus 25.)

${ }^{2}$ Nyugat-magyarországi Egyetem Savaria Egyetemi Központ = A felsőfokú tanító- és óvóképzés első 50 éve. Szekszárd, Pécsi Tudományegyetem Illyés Gyula Főiskolai Kar, 2009. 131-142.p. 
gyakorlatainak videóra vétele és pedagógiai elemzése, s az akkori tanárok a mai napig is használható oktatófilmeket ${ }^{3}$ készítettek. A hallgatók diplomamunkájuk megírásához széleskörü gyakorlati, módszertani, technikai segítséget kaptak, például TV-stúdió, médiatár, oktatástechnikai csoport is müködött a föiskolán.

E hagyományok megőrzésébe kapcsolódott be a SEK Könyvtára, amikor a Médiatár állománya és szolgáltatásai integrálódtak a könyvtárba. Első lépésként a régi kazettákon örzött filmek digitalizálását kellett megoldani, amely során - nagyrészt önképzéssel - a könyvtárosok megtanulták a szoftveres videószerkesztés alapjait. Ezután szerény technikai keretek között elkezdődhetett a különböző rendezvények, előadások felvétele, szerkesztése és nyilvánossá tétele. Technikai fejlődést hozott az egyetem podcast pályázata, amelynek keretében a karok 1-1 videócsomagot - kamera, állvány, hangtechnika, szerkesztőgép, táska, szoftverek - kaptak a felvételek elkészítéséhez. A szombathelyi három kar podcast csomagjait a SEK Könyvtára fogadta be, vállalva azok kölcsönzését, a technikai támogatást, a felvételek elkészítésének szervezését, illetve az anyag szerkesztését és megosztását. 2010-től sikerült bevezetni új szolgáltatásként a folyamatot, s mostanra már több mint 900 videófelvétel érhető el a felsőoktatás videóportálján a Videotorium adatbázisban. A feltöltött és megosztott felvételek több mint 90\%-a nyilvánosan elérhető. ${ }^{4}$

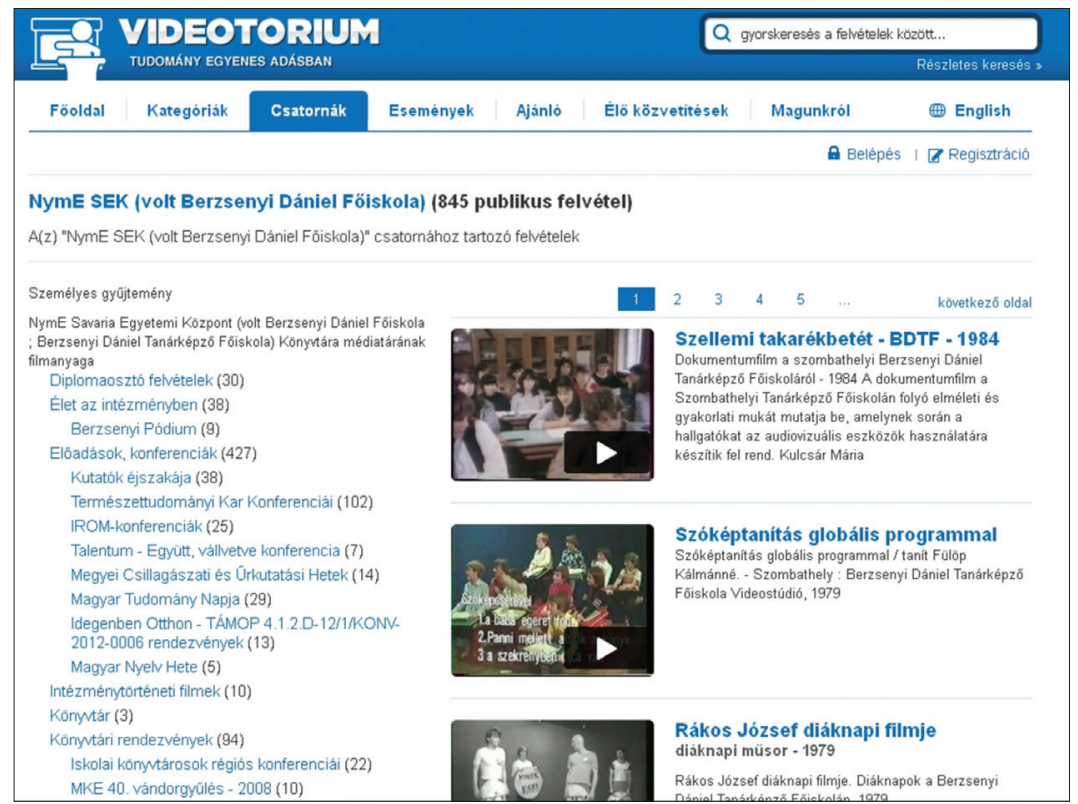

2. ábra. A SEK Könyvtára csatornája a Videotorium.hu portálon

\footnotetext{
${ }^{3} \mathrm{http} / / /$ videotorium.hu/hu/channels/292/oktatofilmek (2016. augusztus 25.)

${ }^{4} \mathrm{http} / / /$ videotorium.hu/hu/channels/273 (2016. augusztus 25.)
} 
A nyugati modell alapján kialakított podcast lényege, hogy az oktatók felveszik saját előadásaikat, és azt valamilyen hozzáférési joggal visszaosztják a hallgatóiknak. Az oktatók terheinek csökkentése, valamint a minőségi oktatás elősegítése érdekében a folyamat nagy részét a könyvtár átvállalja, így az oktatóknak csak a tartalomra kell koncentrálniuk.

Mintaprojektként a Gimnasztika tantárgy teljes előadásanyaga és gyakorlati óráinak videófelvételei készültek el. Az oktató igényei alapján többkamerás rögzítés történt, majd a PinnacleStudio szoftver idősávjain szerkesztettük meg a végső változatot. Az oktató végignézte, bejelölte a vágási pontokat, amely alapján már egyszerủ volt a végső anyagot összeállítani. Hosszabb távon a gyakorlatban pedig sikerült kialakítani azt a munkarendet, amely alapján a lehető legkevesebb munkaidő ráfordítással elkészíthető az óra végleges felvétele.

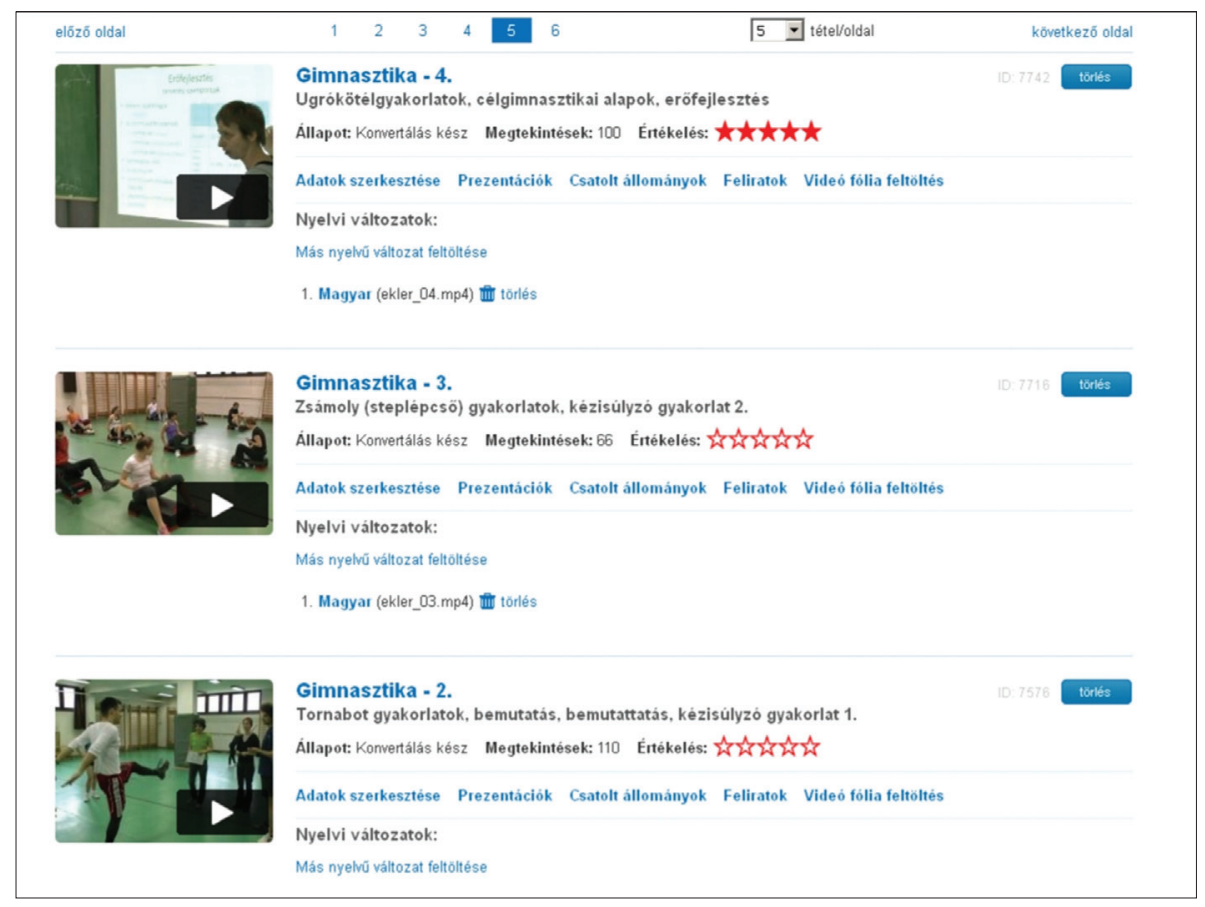

3. ábra. Gimnasztika órafelvételek a Videotorium.hu portálon

Az oktató a Google kérdőív szerkesztő szolgáltatása segítségével részletes felmérést készített a videós projekt oktatásra gyakorolt hatásáról. A visszajelzések alapján elmondható, hogy a hallgatók pozitívan értékelték a későbbi visszanézés lehetőségét, az értékeléseknél pedig jobb eredményeket értek el, mint az előző évfolyamok.

Az órai felvételek mellett a legtöbb film a különböző rendezvényekhez, konferenciákhoz, előadás-sorozatokhoz kapcsolódóan készült el. Az eddigi tapasz- 
talatok szerint - a jelenleg rendelkezésre álló technikai feltételek mellett - a felvétel idejének átlagban a háromszorosa az az időtartam, amely alatt a videó az interneten hozzáférhetővé válik.

\section{Videotorium.hu, a felsőoktatási videóportál}

A podcast szolgáltatás második alappillére az anyagok Videotorium-ban ${ }^{5}$ való közzététele. E videómegosztó legnagyobb erénye a sokrétű metaadatleírási és visszakeresési lehetőség mellett a segédanyagok, feltöltött prezentációk felvételhez füzhetősége. A diák a lejátszás során valós időben megjelennek a videó mellett, így nem kell törekedni a profi kamerás felvételekre. Utólag jó minőségben lehet mellékelni bármilyen segédanyagot, amely a megértést könnyíti, és nem a videószerkesztésben kell sok munkával elhelyezni a felvételen. A hatékony visszakeresést támogatva a Videotorium keresőmotorja a feltöltött prezentáció szövegében is keres.

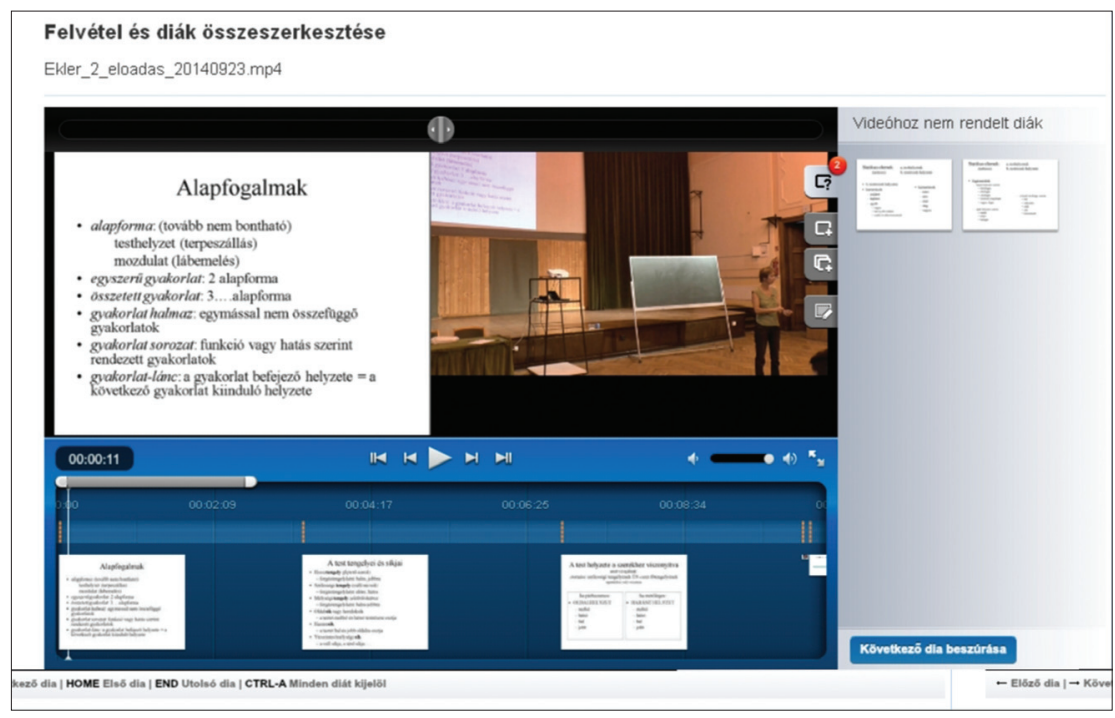

4. ábra. Prezentáció hozzárendelése a Videotorium.hu portálon

Az e-tananyagok készítéséhez is ezt a technikai megoldást ajánlják a könyvtár munkatársai. A Videotorium szolgáltatási rendszerében lehetőség van szöveges állományok feltöltésével (például srt, sub) feliratok elhelyezésére, prezentáció helyett a számítógép képernyőjén rögzített videó mellékelésére, valamint többnyelvű felvételek feltöltésére, párhuzamos kezelésére, kiegészítő dokumentációk megosztására. Az oktatók által készített előadások hozzáférési jogai is jól szabályozhatók a rendszerben (EduID, IP-cím, csoportok, időalapú beállítás

${ }^{5} \mathrm{http}: / /$ videotorium.hu (2016. augusztus 25.) 
stb.), például a már említett gimnasztika előadások megtekintését csak a levelező képzésben résztvevő hallgatók számára engedélyezte az oktató.

A könyvtárban két könyvtáros foglalkozik a podcast szolgáltatás müködtetésével, a felvételek szerkesztésével, megosztásával. Időszakosan sikerül bevonni hallgatókat, közösségi szolgálatban résztvevő tanulókat is egyes részfeladatok elvégzésébe, elsősorban a felvételek készítésébe és a prezentációk hozzáfüzésébe.

A Videotorium-ba feltöltött több mint 900 felvétel nézettségi statisztikája azt mutatja, hogy a hallgatók szívesen használják és látogatják e felületet: a 2015. évi statisztika már 50 ezer feletti kattintási értéket mutatott. A tanulási szokások változását jól érzékelteti, hogy a sport témájú oktatófilmek, előadások a teljes nézettség 50 százalékát teszik ki. Az úszással, tornával, sportpedagógiával stb. foglalkozó oktatófilmek ( $56 \mathrm{db}$ ) folyamatosan a Videotorium nézettségi toplistái élén járnak.

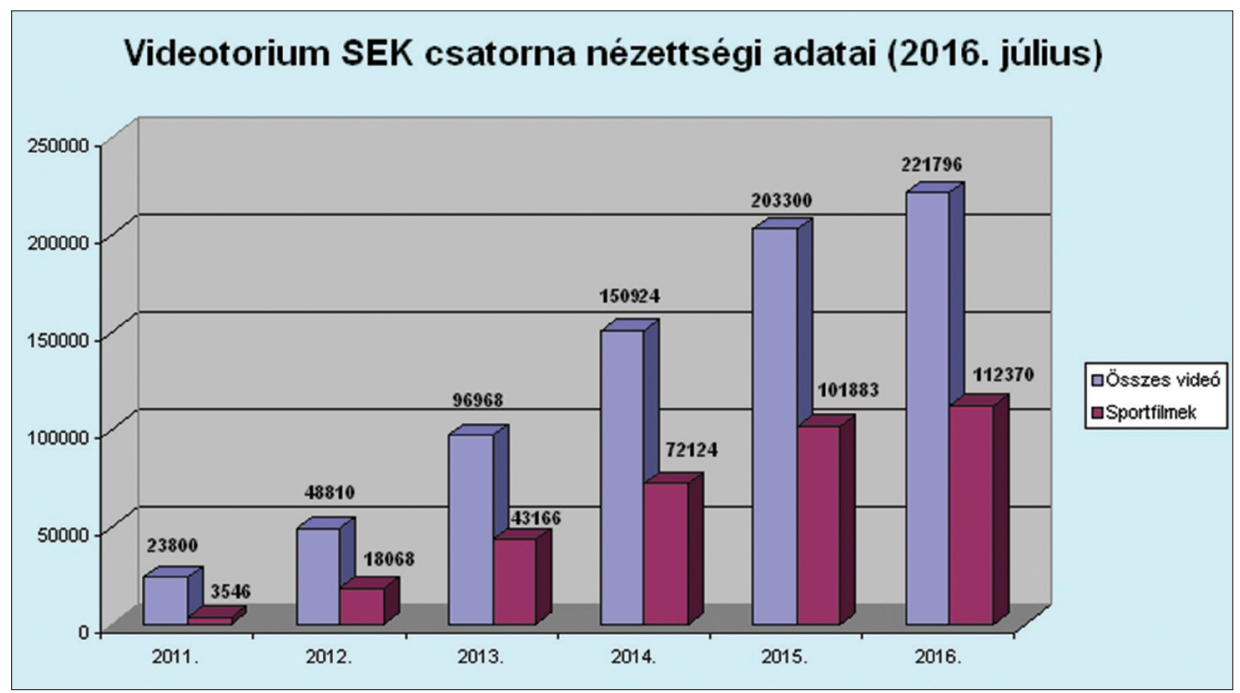

5. ábra. SEK Könyvtára felvételeinek nézettségi adatai a Videotorium.hu portálon

\section{Moodle oktatási keretrendszer}

A SEK Könyvtárának 5 munkatársa vett részt elektronikus tananyagkészítéssel kapcsolatos továbbképzéseken, amelyeknek egyik alapeleme a Moodle-learning ${ }^{6}$ keretrendszer elsajátítása volt. A megszerzett ismeretek segítségével a könyvtárosok a szombathelyi pedagógusképzés támogatására létrehozott Moodle felületen a rendszeradminisztrációs tevékenység mellett egyénre szabott módszertani oktatást is nyújtanak az oktatók részére. A Moodle-kurzusok kialakítása során konkrét javaslatokkal segítik a könyvtári szolgáltatások (DRM, plágiumkeresés, Videotorium, digitalizálás stb.) integrálását, támogatva a tanítási/tanulási folyamatot.

\footnotetext{
${ }^{6} \mathrm{http}: / /$ nyo.pszk.nyme.hu (2016. augusztus 25.)
} 
Az alkalmazás ismét egy Gimnasztika kurzushoz kapcsolódó példával illusztrálható. A testnevelés szakos hallgatók rajzírás tanulásának elősegítése érdekében digitalizálásra került az összes rajzírásforma, majd ezek felhasználásával kérdésbank és gyakorló tesztek készültek. A hallgatók a gyakorló tesztek segítségével memorizálhatták a rajzokhoz tartozó fogalmakat.

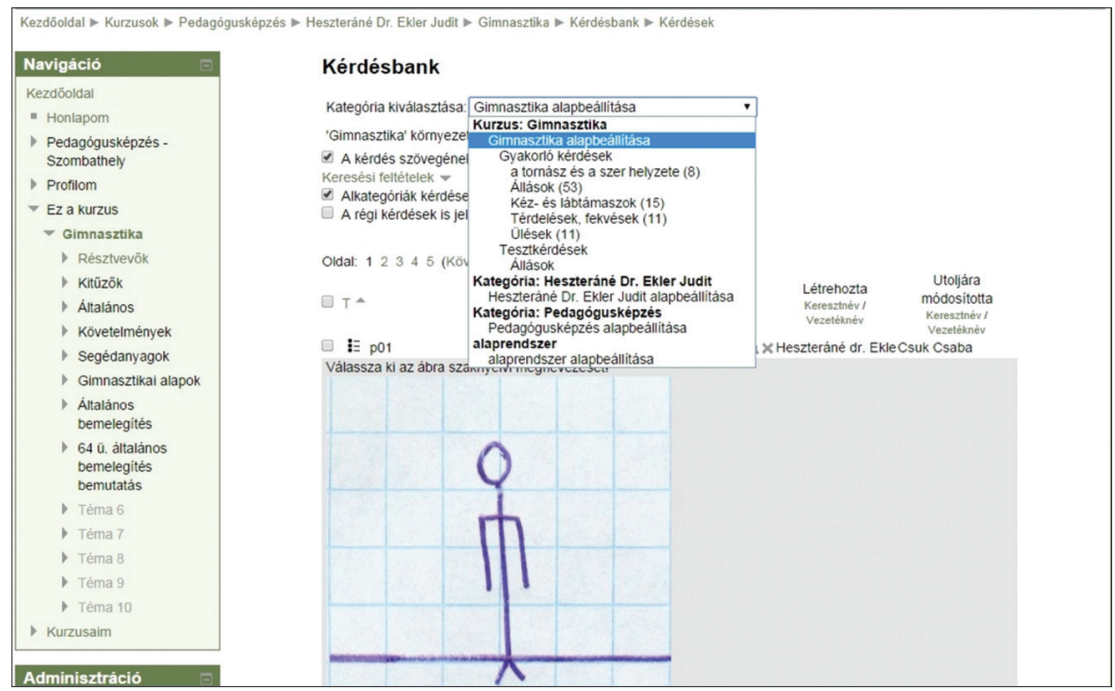

6. ábra. Kérdésbank a Savaria Egyetemi Központ Moodle portálján

\begin{tabular}{|c|c|c|c|}
\hline \multicolumn{4}{|l|}{ Gimnasztika } \\
\hline \multicolumn{4}{|c|}{ A(z) 2014. jünius 30., héttö, $06: 54$ óta gyūjtôtt naplókból kiszámitva. } \\
\hline Tevékenység & Nézetek & Kapcsolódó blogüzenetek & Utolsó belépés \\
\hline Eä́ltalànos nirfórum & 145 & - & 2014. oktober 8. szerda, 19.53 ( 4 b́ra 10 perc) \\
\hline 䂇 Az ezerarcú gimnasztika & 21 & . & 2014. szeptember 29, hétro, $12: 00$ (9 nap 12 óra) \\
\hline \multicolumn{4}{|c|}{ Követelmények } \\
\hline Enappali tagozat & 168 & - & 2014. oktiober 8. szerda. $11: 47$ (12 óra 17 perc) \\
\hline Levelezö tagozat & 95 & - & 2014. oktober 8, azerda, $17: 17$ ( 6 ora 46 perc) \\
\hline Részképzés & 47 & - & 2014. oktober 8, szerda. $20: 11$ ( 3 ora 52 perc) \\
\hline \multicolumn{4}{|c|}{ Segédanyagok } \\
\hline Segédanyagok & 253 & - & 2014. oktober 8, szerda, $21: 52$ (2 ora 12 perc) \\
\hline - 96 ütemũ gyakorlat bemutatója - vidé & 94 & - & 2014. oktober 8, szerda, $21: 38$ (2 bra 25 perc) \\
\hline$\checkmark$ Gyakorió teszlek a rajzirás tanulásához - állások & 2133 & - & 2014. oktober 8 , szerda, $21: 38$ (2 ora 26 perc) \\
\hline$\checkmark$ Gyakorló teszlek a rajzirás tanulásához - ülések & 961 & - & 2014. oktober 8 , szerda, 21,36 (2 bra 27 perc) \\
\hline$\nabla$ Gyakorio teszlek a rajzirás tanulásánoz - kèz- és lábtámaszok & 984 & - & 2014. oktober 8 . szerda, 21.46 ( 2 ora 18 perc) \\
\hline$\checkmark$ Gyakorló teszlek a rajzirás tanulásához - térdelések és fekvések & 795 & - & 2014. oktober 8, szerda, $21: 33$ (2 bra 30 perc) \\
\hline$\checkmark$ Gyakorlo teszlek a rajziras tanulásánoz - a tornász és a szer nelyzete & 1169 & - & 2014. oktober 8, szerda, 21.53 (2 óra 10 perc) \\
\hline Gimnasztika elōadások levelezósōknek & 7 & - & 2014. oktober 8, szerda, $21: 19$ (2 ora 44 perc) \\
\hline \multicolumn{4}{|c|}{ Gimnasztikai alapok } \\
\hline B. Gimnasztikai alapok & 187 & . & 2014. oktober 8 , szerda, 20.21 ( 3 óra 43 perc) \\
\hline
\end{tabular}

7. ábra. Gimnasztika gyakorló tesztek nézettségi adatai a Savaria Egyetemi Központ Moodle portálján 
A kurzus zárótesztjében már a hallgatóknak kellett beírni a megfelelö fogalmakat. A Moodle statisztikája szerint a hallgatók a gyakorló teszteket tömeges méretekben kezdték el használni, jobbak lettek az eredményeik, és az oktatónak sikerült elérni, hogy a tanulók már év közben is foglalkozzanak a tananyaggal.

A könyvtár módszertani támogatásának fő eleme, hogy az oktatók megtalálhassák oktatási folyamatuk azon pontjait, amelyeket hatékonyabbá tudnak tenni a Moodle rendszer használatával.

\section{MAHARA e-portfólió rendszer}

A Moodle rendszerrel párhuzamosan bevezetés alatt áll a MAHARA ${ }^{7}$ e-portfólió szolgáltatás is. A keretrendszer felhasználói közvetlenül a Moodle felületéről tudják átküldeni az elkészített e-dokumentumaikat a MAHARA-ba, és ott saját oldalon gyüjthetik össze, mutathatják be a munkásságukat (e-portfóliójukat), segítve például a későbbi elhelyezkedésüket. Cél továbbá a pedagógusképzés során keletkező portfoliók e-alapú formájának kialakítása, amely részét képezheti a tanulmányi követelményrendszernek is.

\section{Turnitin/Ephorus plágiumkereső szolgáltatás}

A SEK Könyvtára a minőségi oktatást segítendő szolgáltatásként az Ephorus ${ }^{8}$ plágiumkereső rendszert vezette be a TÁMOP-3.2.4.A-11/1-2012-0060 „,Tudásdepó-Expressz" pályázat keretében. A karokon fogalmazódott meg az igény, hogy az intézményben keletkező e-dokumentumok (elsősorban a diplomadolgozatok) plágiumellenőrzése megvalósuljon. Az Ephorus cég vállalta a 2003 óta már digitálisan őrzött szakdolgozatok betöltését, így már az indulásnál több mint 10000 diplomadolgozat szerepelt keresési alapként. Ezenkívül a rendszer több mint 1 millió weblap tartalmával is összehasonlítja a dokumentumokat, megkímélve az oktatót a keresgéléstől. A rendszer müködését a 8. ábra szemlélteti.

A folyamat lényege:

1. Meghívó alapján az oktató regisztrál és létrehozza a dokumentum feltöltéséhez szükséges kódot a plágiumkereső webes felületén. ${ }^{9}$

2. A hallgató a feltöltő ürlapon ${ }^{10}$ keresztül az oktató által megadott adatok (kód) segítségével feltölti a szöveges dolgozatát.

3. A plágiumkereső végrehajtja az összehasonlítást, és a jelentést e-mailben elküldi az oktatónak.

\footnotetext{
${ }^{7}$ http://eportfolio.nyme.hu (2016. augusztus 25.)

${ }^{8} \mathrm{https}: / /$ www.ephorus.com (2016. augusztus 25.)

${ }^{9} \mathrm{https}: / /$ www1.ephorus.com (2016. augusztus 25.)

${ }^{10} \mathrm{http}: / /$ sek.nyme.hu/konyvtar/plagium (2016. augusztus 25.)
} 


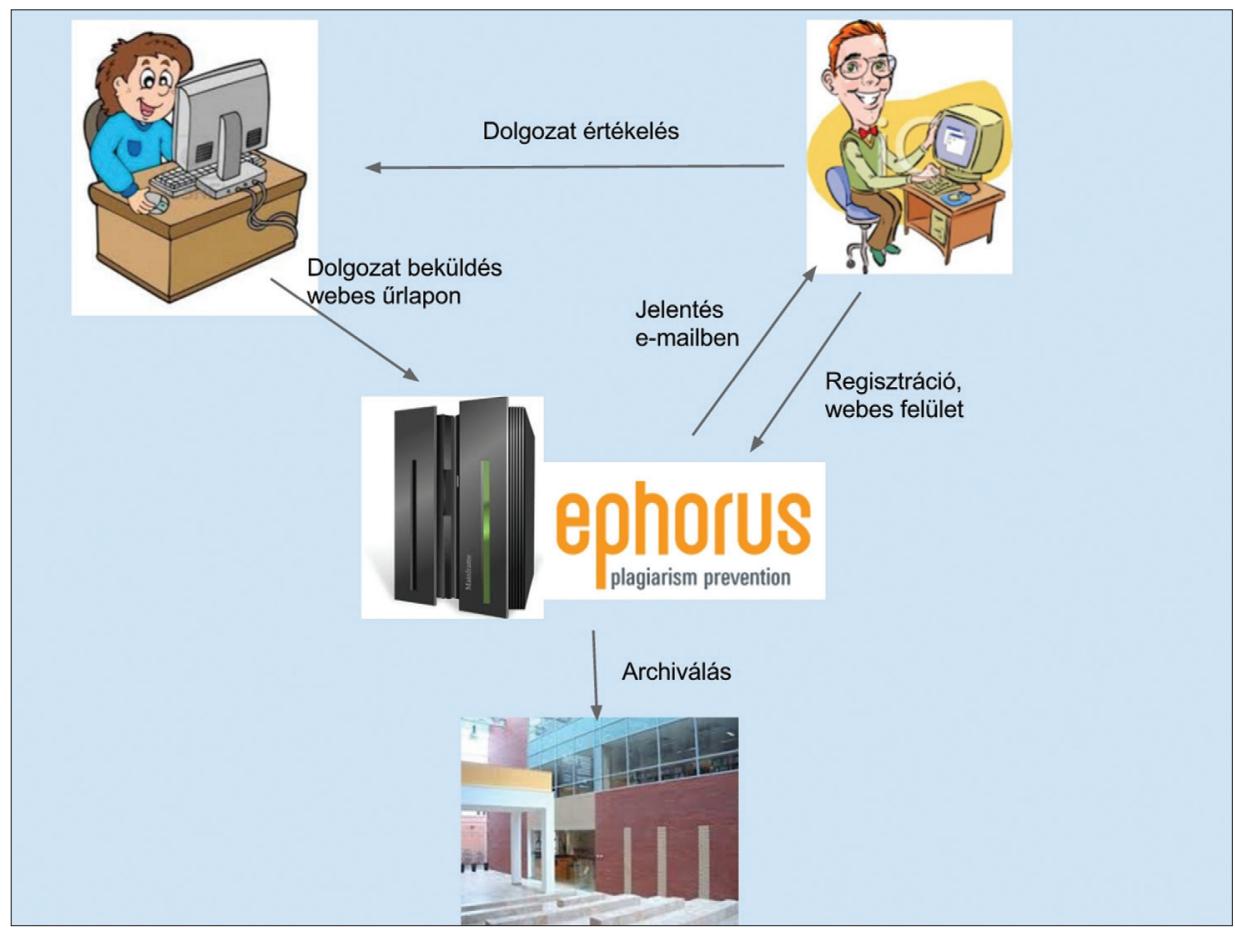

8. ábra. Plágiumkereső szolgáltatás folyamata a Savaria Egyetemi Központ Könyvtárában

A megőrzés biztosítása érdekében, valamint az oktatók munkájának segítése céljából a könyvtár az első pontban szereplő ürlapot kiegészítette két funkcióval. A feltöltés során a dokumentum elmentésre kerül a helyi könyvtári szerverre, ugyanakkor az oktató e-mailes értesítést kap a feltöltésről, amely tartalmazza az eredeti dokumentumhoz vezető letöltési linket is, így nem kell belépnie a plágiumkeresőbe. Végeredményben az oktatónak egy egyszeri regisztráció és kódbeállítás után már csak az e-mailben megkapott plágiumkeresési jelentést kell értékelnie. A jelentés szemléletesen, az egyes találati helyeket külön kezelve, könnyen értelmezhetö formában mutatja meg a szövegegyezéseket. Nyugati gyakorlat alapján a szolgáltatás elsődleges célja a hallgatók szerzői jogoknak megfelelő idézési kultúrájának fejlesztése. 


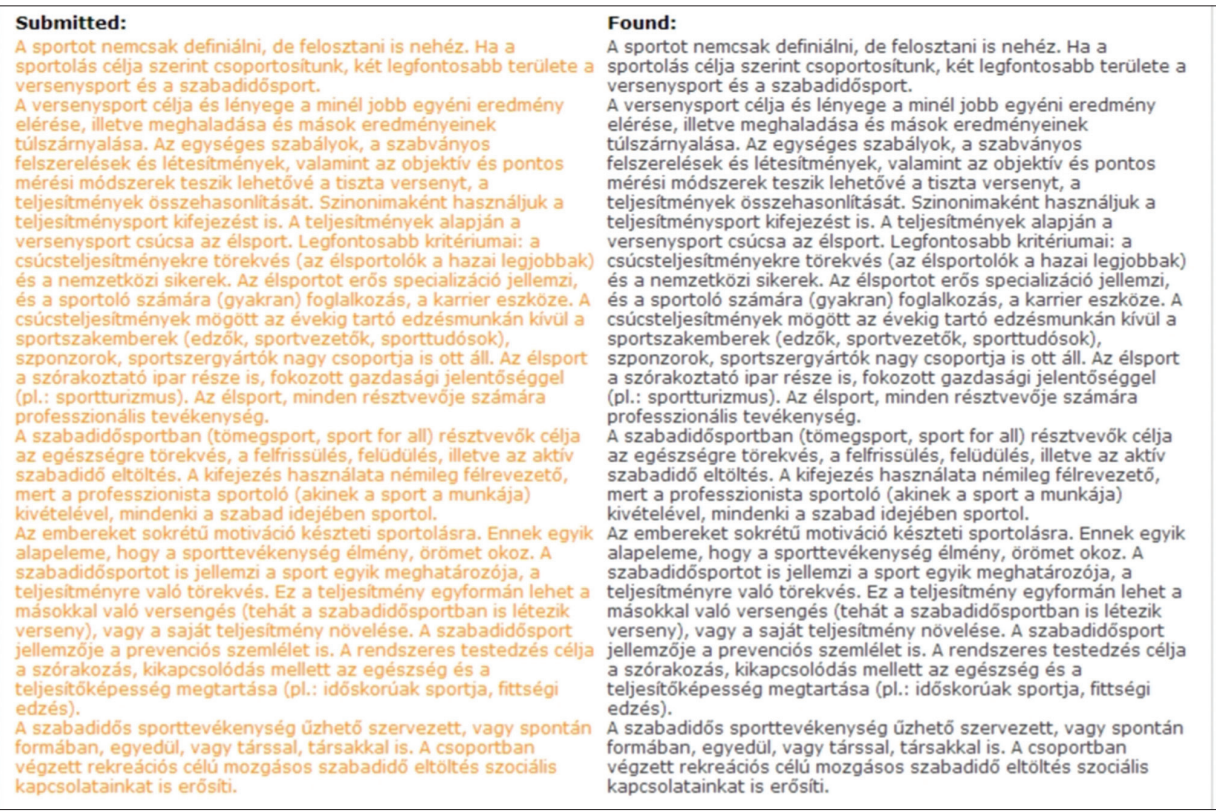

9. ábra. Turnitin/Ephorus plágiumkereső szolgáltatás plágiumjelentése

\section{Drupal (CMS) tartalomkezeló rendszer}

A SEK Könyvtára 2011-ben könyvtárosi adminisztrátor fejlesztésével kezdte el használni a Drupal ${ }^{11}$ keretrendszert, míg előtte Wordpress és Joomla tartalomkezelők láttak el célirányos funkciókat. A különböző igényeknek megfelelő szoftver az alábbi kritériumok alapján került kiválasztásra:

a) többfelhasználos tartalomkezelő, ahol bármely kolléga, felhasználó tartalmat állíthat elő a jogosultsági szintjének megfelelően;

b) Vezetői Információs Rendszer (VIR) kialakítása: könyvtárosok információközvetítő helye, ahol mindenki ugyanazt a könnyen visszakereshető tartalmat látja, kommunikálhat a rendszer segítségével, illetve bárhonnan elérheti;

c) különböző dizájn lehetőségével egyszerüen hozható létre új weblap az igényeknek megfelelöen;

d) saját webes adatbázisok hozhatók létre programozói tudás nélkül;

e) többnyelvüség támogatása.

Elsőként a könyvtár új honlapja ${ }^{12}$ készült el Drupal segítségével, amelybe áttöltésre került a korábban Wordpressben müködő könyvtári Vezetői Információs Rendszer.

${ }^{11} \mathrm{http}: / /$ www.drupal.hu (2016. augusztus 25.)

12 http://tudastar.nyme.hu/sekkonyvtar (2016. augusztus 25.) 
Elkészült egy Média adatbázis, ${ }^{13}$ ahol az intézménnyel kapcsolatos sajtófigyelések adatai kerülnek rögzítésre, kiegészülve az eredeti híradás teljes szövegủ másolatával, és/vagy digitalizált (pdf) változatával. A szerkezet kialakításánál fontos elv volt, hogy az egyes képzési területek (például kar, intézet, sport) önállóan is leválogathatók legyenek, így egyszerüen felhasználhatják a szakok akkreditációjában vagy a pályázati elszámolásoknál is.

A Magyar Nyelvi Tanszék által gyüjtött, felbecsülhetetlen értékủ Élő nyelvi hanganyag gyüjtemény webes felületén ${ }^{14}$ a magnókazettákról digitalizálandó hangfelvételek válnak közkinccsé.

A Savaria Egyetemi Központ Könyvtára honlapján kívül jelenleg 8 féle különböző honlap ${ }^{15}$ üzemel ugyanazon Drupal motoron keresztül. Például az Ünnepi Könyvheti Felolvashow - SZombathely az Olvasás Fövárosa Is (SZOFI) ${ }^{16}$ rendezvénysorozatunk már 5 éve népszerüsíti az olvasás mellett intézményünket is.

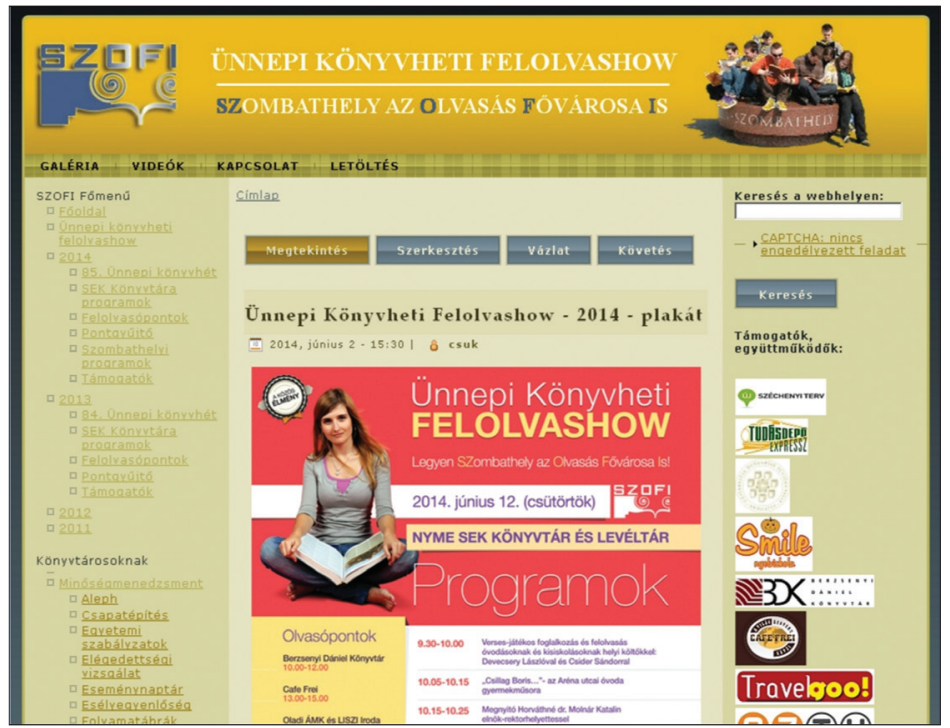

10. ábra. Drupal alapú weblap a Savaria Egyetemi Központ Könyvtárában

A szombathelyi felsőoktatás története ${ }^{17}$ címü honlap kívánja összegyüjteni az intézmény történetével kapcsolatos információkat és dokumentumokat, amelyek a könyvtár irányításával digitalizálásra kerülnek.

${ }^{13} \mathrm{http}: / /$ tudastar.nyme.hu/sekkonyvtar/sajto/teljes (2016. augusztus 25.)

${ }^{14} \mathrm{http}: / /$ tudastar.nyme.hu/sekkonyvtar/elonyelv (2016. augusztus 25.)

$15 \mathrm{http} / / /$ tudastar.nyme.hu/sekkonyvtar/content/sek-koenyvtara-tematikus-weblapjai (2016. augusztus 25.)

${ }^{16} \mathrm{http} / / /$ tudastar.nyme.hu/sekkonyvtar/szofi (2014. június 30.)

${ }^{17} \mathrm{http}: / /$ tudastar.nyme.hu/sekkonyvtar/intezmenytortenet (2016. augusztus 25.) 


\section{Digitális dokumentumtárak (NymETudástár, ${ }^{18}$ Intranet, Google szolgál- tatások $^{19}$ )}

Az oktatók e-tananyagai, az oktatási céllal digitalizált kötelező irodalmak, az intézménnyel kapcsolatos dokumentumok szükségessé teszik digitális dokumentumtárak használatát. A SEK Könyvtára intraneten már 2003-tól müködtet a szerzői jogszabályoknak megfelelő DRM szolgáltatáson alapuló e-dokumentumtárat. Az intézményi IP-címtartományból elérhető oktatói jegyzetek, diplomadolgozatok, tanítási segédanyagok csak olvasásra jeleníthetők meg a képernyőn. 2010-től az egyetemi könyvtári rendszerben pályázati támogatásból létrejött a NymE Tudástár dokumentumtár. Célja az egyetemen keletkezett e-dokumentumok egységes, viszszakereshető, DRM-mel szabályozható, dokumentumtípustól független, interneten bárhol elérhető digitális szolgáltatása elsősorban az egyetem polgárai számára.

Egy felsőoktatási könyvtárban ma már alapszolgáltatásnak kell tekinteni a digitális dokumentumtár(ak) müködtetését, de ami még fontosabb, hogy ezt meg kell ismertetni és használtatni is kell az oktatókkal, és be kell építeni a digitális tanulás folyamatába.

\section{8 . Magyar Tudományos Múvek Tára (MTMT) ${ }^{20}$}

A tudományos publikációk bibliográfiai adatainak gyüjtésére szánt Magyar Tudományos Mủvek Tára adatbázis használata során kiderült, hogy a szerzők többségének nincs gyakorlata szabványokon alapuló metaadatbázisok építésében. Az egyes intézményekben az MTMT adminisztrátori tevékenységével eleve könyvtárosokat bíztak meg, akik az ellenőrzési folyamatok során inkább maguk viszik be a publikációkat az adatbázisba. Az utólagos javítások, adatkeresések sokszor több időt vesznek igénybe, ezért kapacitástól függően a könyvtárosok vállalják el az adatbevitelt is. A helyismereti gyüjteményben tárolt publikációkat önkéntesek digitalizálják, majd az MTMT adminisztrátorok csatolják az egyetemi repozitóriumban lévő rekordhoz.

\section{Összegzés}

A Savaria Egyetemi Központ Könyvtára minden szolgáltatására igaz, hogy a leterhelt oktatói és hallgatói felhasználói kör részére minél egyszerübb és automatizáltabb megoldásokat igyekszik nyújtani. A könyvtárosoknak folyamatosan bővíteniük kell kompetenciáikat nemcsak informatikai, hanem oktatási területeken is. Szükséges az oktatók, hallgatók és minden könyvtárhasználó számára direkt, személyre szabott képzések biztosítása, azonnali „ügyfélkapcsolati szintü” szolgáltatások bevezetése. A SEK Könyvtára a bemutatott tanulástámogató szol-

\footnotetext{
${ }^{18} \mathrm{http}: / /$ tudastar.nyme.hu (2016. augusztus 25.)

${ }^{19} \mathrm{https}$ ://www.google.hu/intl/hu/about/products (2016. augusztus 25.)

${ }^{20} \mathrm{https}: / /$ www.mtmt.hu (2016. augusztus 25.)
} 
gáltatások alkalmazásán keresztül kívánja - megfelelve a 21. század elvárásainak - direkt módon közvetíteni azokat a tartalmakat, amelyekre az oktató, kutató munka során használóinak szüksége lehet.

\section{Rezümé}

Az előadás összefoglalóan bemutatja azokat a digitális szolgáltatási eszközöket, formákat, amelyeket a NymE Savaria Egyetemi Központ Könyvtára alkalmaz a megváltozott tanulási környezetben. A hagyományos könyvtári ellátás mellett a könyvtár bekapcsolódik az intézmény e-learning adminisztrátori feladataiba, továbbképzi az oktatókat és hallgatókat, módszertani segítséget nyújt az elektronikus tananyagok elkészítéséhez. Podcast eszközrendszer használatával törekszik az 1980-as évek ,,szombathelyi modell”jének felújítására. Eszközökkel, módszertani és szerkesztési támogatással segíti az oktatókat az oktatás digitális világának kialakítására, valamint plágiumkereső szolgáltatással támogatja munkájukat. A hallgatók jogszabályok szerinti dokumentumellátását elektronikus dokumentumtárakkal biztosítja.

\section{Teaching and Learning Support Services in Savaria Campus Library}

My paper presents the digitaltools and services that Savaria Campus Library, University of West Hungary provides for the users in the constantly changing learning environment. Besides the traditional library services our library is engaged in e-learning, provides training for the teachers and the students, and also provides methodological support for preparing e-learning materials. Applying podcast technology our library wants to revive the so-called "Szombathely model", which was an educational methodology in the 1980s based on state-of-the-art technology. Our library supports educators in shaping the digital educational and research environment by providing tools, technology and methodology. We also help teachers in originality checking to fight plagiarism by providing Ephorus (Turnitin) service. We also support the learning and teaching activities by building an electronic document repository.

CSUK CSABA

könyvtárigazgató-helyettes

Nyugat-magyarországi Egyetem Savaria Egyetemi Központ Könyvtár és Levéltár 



\section{Az ELTE Egyetemi Könyvtár ősnyomtatványtára}

\section{Az ősnyomtatvány kifejezés eredete, használata}

A latin ,incunabulum” kifejezést egy német filológus, Bernhard Mallinckrodt (Mallinkrot, 1591-1664) használta elöször az 1640-ben Kölnben (typ. Kinchius) megjelent, De ortu ac progressu artis typographicae dissertatio historica címü munkájában. ${ }^{1}$ A megjelöléssel a legkorábbi, 1500 vége előtt készült nyomdatermékeket illette. Ösnyomtatvány az a könyv vagy egyleveles kiadvány, amelyet az európai könyvnyomtatás feltalálása óta, azaz az 1450-es évek közepétől a XV. század végéig, pontosabban 1500. december 31-ig mozgatható betükkel, szedéssel-nyomással állítottak elő. Nem számítanak ősnyomtatványnak az úgynevezett táblanyomatok, valamint a Kínában, Koreában és általában a Távol-Keleten ebben az időszakban sokszorosított munkák. Az 1500. december 31-i könyvészeti korszakhatár hosszú ideig vitatott volt, ugyanis egyrészt a kisebb, Alpoktól északra müködő nyomdákból még 1520-1530 körül is kerültek ki olyan nyomtatványok, melyek tipográfiája ötven évvel korábbi sajátosságokat hordozott. Másrészt a velencei nyomtatványok már 1490 körül úgy készültek, mint a XVI. századi kiadványok, volt címlapjuk, levél- vagy lapszámozásuk, aránylag kevés rövidítéssel éltek és az előállításukhoz a korábban használt betűtípusoktól eltérően, jól olvasható antikva betütípust használták. ${ }^{2}$

Gutenberg és első követői a gót misekönyvek betüit vették alapul a betűmetszéshez. Később, 1464-ben a strassburgi Adolf Rusch egy másik, a kódexekben kedvelt betütípust választott a metszett betük készítéséhez, az antikvát. A két betütípus hamarosan az ősnyomtatványok tartalmához igazodott: gót betükkel általában a liturgikus és bibliai szövegeket nyomtatták ki, az antikvát pedig a klasszikus latin szövegekhez használták fel.

\footnotetext{
${ }^{1}$ A kötetből az ELTE Egyetemi Könyvtár nem őriz példányt, Magyarországon az Országos Széchényi Könyvtárban található meg a nyomtatvány a 302.718 jelzeten.

${ }^{2}$ E különbségek vezettek oda, hogy például a lipcsei Egyetemi Könyvtár incunabulumkatalógusa sokáig az itáliai ősnyomtatványokat csak 1480-ig tartotta számon. Más ősnyomtatvány-katalógusok ugyanakkor a reformáció évével, 1520-szal vagy 1550-nel zárták le az ősnyomtatványok korát. Magyarországon például Récsey Viktor a pannonhalmi régi nyomtatványok katalógusa készítése kapcsán az 1536-os évet tekintette korszakhatárnak.
} 


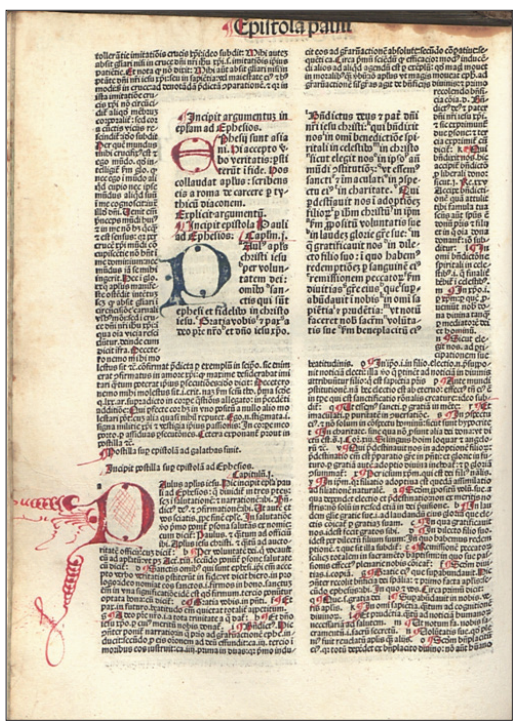

1. kép. Gót betüs ősnyomtatvány Biblia, Nürnberg, 1485, 235v Inc 278

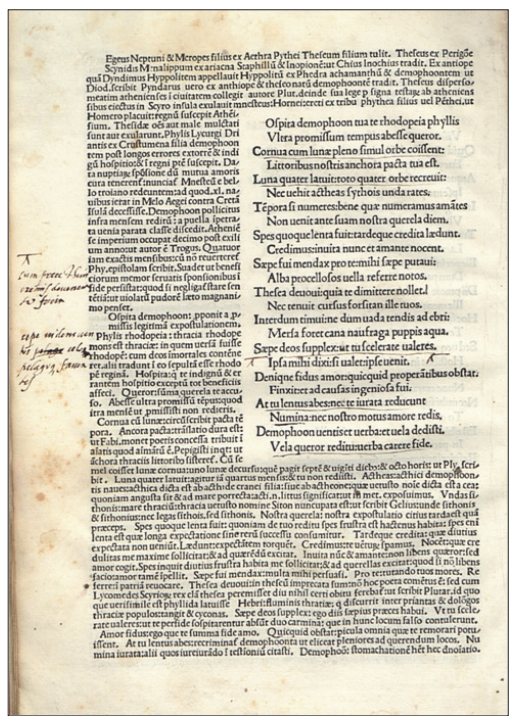

2. kép. Antikvával készült ősnyomtatvány. Publius Ovidius Naso, Epistolae heroides, Velenzia, 1482, 4v Inc 128

Az ősnyomtatványok világszerte a legdrágább dokumentumok közé tartoznak. ${ }^{3}$ Különleges értéküket nem elsősorban a tartalmuk határozza meg, közrejátszik benne a nyomdászattörténeti jelentőség, a régiség és az egyedivé tett állapot.

\footnotetext{
${ }^{3}$ http://www.forumrarebooks.com/index.html?nav_id=1 (2015. november).
} 


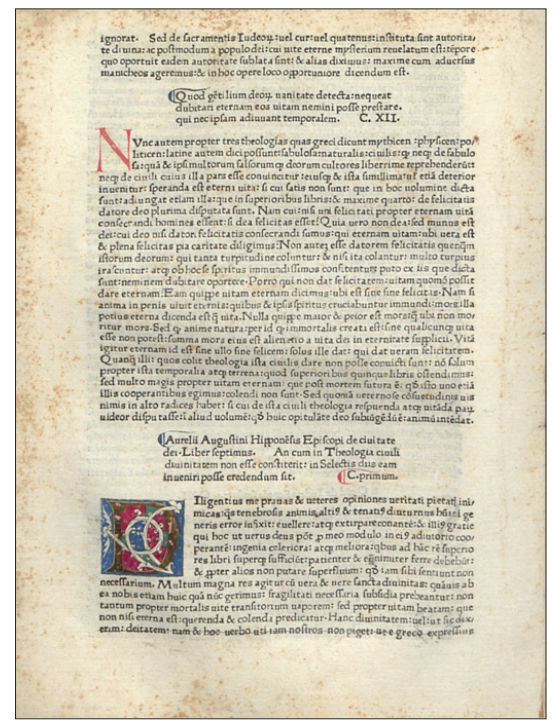

3. kép. Szent Ágoston, De civitate Dei, Roma, 1474, Inc 16

A legértékesebbek a könyvnyomtatás feltalálásához időben közelebb álló munkák. ${ }^{4}$ A XV. századi ösnyomdákból becslések szerint mintegy 35.000 mü közel 500.000 példányban került ki. E becses nyomtatványok többi nyomdaterméktől elkülönített gyüjteményi kezelése a XVII. századtól követhető nyomon.

\section{A legkorábbi ősnyomtatványok könyvészeti sajátosságai}

A XV. század második felének nyomdászai tudatosan törekedtek arra, hogy munkáik hasonlítsanak a középkori kézzel írott könyvekhez, a kódexekhez. Ennek érdekében a kódex-írás főbb betütípusain (gót, antikva) kívül az ősnyomdászok átvették a kódexekben használt rövidítéseket (abbreviatura) is, s ezek használatával biztosították a sorok azonos hosszúságát. A mintegy hatvan-nyolcvan általánosan használt rövidítés mellett kedveltek voltak a ligatúrák (közös matricára öntött kettős betűk) is. ${ }^{5} \mathrm{Az}$ egyes kiadások példányszáma eleinte alacsony volt.

${ }^{4}$ Kiemelkedően értékesek mindazok az ősnyomtatványok, melyek egy-egy település vagy műhely első termékei közé tartoznak, továbbá az úgynevezett ritka, kis számban készült vagy fennmaradt kiadványok. A ritka kiadványok közül kiemelkednek mindazok az ősnyomtatványok, amelyek mindössze egyetlen ismert példányban maradtak fenn (unikum példányok). Különösen értékesek továbbá a pergamenre nyomott, a középkori minta szerint kézzel díszített és az antik auktorok múveit tartalmazó kötetek.

${ }^{5}$ További középkori „örökség” volt a széles margó, ami fennmaradt az „ösnyomdászok” első generációi körében is; vagy ők, vagy a kötetek megvásárlói anyagi lehetőségeik függvényében díszíttethették és köttethették be a megvásárolt, sok esetben hajtogatás elötti (krúda) nyomtatott „könyveket”. Mindez azt jelenti, hogy az ősnyomtatványokon - éppúgy, mint a kódexeken - általában különböző, minimálisan két személy dolgozott: a nyomdász és a kötet díszítéseit készítő 
A példányszámok emelkedését elsősorban az ösztönözte, hogy egy-egy kötet teljes elöállítási ára körülbelül egyharmada volt a korábbi kéziratos kódexekének. Címlapja, jobban mondva címlap-őse eleinte még nem volt az ősnyomtatványoknak. Az első „címlap”-pal rendelkező ősnyomtatványt Velencében készítették Nicolas Jenson nyomdájában (1485), nagyon rövid szöveget, a címet és a szerző nevét tartalmazta. ${ }^{6} \mathrm{Az}$ ösnyomtatványok - eltérően a mai nyomtatványoktól olyan ívfüzetekből állnak, melyeknél az íveket egymásba helyezték. ${ }^{7}$ Nehéz és fáradságos munkafolyamat a kelendőbb müvek újabb kiadásainak elkülönítése. Nem ritkák az ugyanazon kiadásokon belüli variánsok sem - ezek általában úgy keletkeztek, hogy a nyomás alatt egyúttal korrigálást is végeztek. Ha például egy ívből már kinyomtak száz példányt és ekkor fedezték fel a hibát, egyszerüen korrigálták, s így ugyanazon ív további példányai már részben eltértek az előbbiektől. Az ősnyomtatványok sajátos könyvészeti megjelenése miatt feldolgozásuk körültekintő figyelmet kíván. ${ }^{8}$ A katalogizálás során érdemes tudományos kuta-

miniátor. Néhány évtizeddel a könyvnyomtatás feltalálása után a nyomdászok igyekeztek azzal „kiváltani" az illuminátorok munkáját, hogy fametszetes keretdíszt és iniciálét nyomtattak a kötetek első, kezdő fóliójának rectó oldalára, amit kézzel tovább lehetett díszíteni festéssel vagy rajzolással. A díszítés további lehetősége volt az úgynevezett rubrumozás (a bekezdések, illetve a mondatok kezdőbetűinek jelzése piros tintás áthúzással). Ezáltal - a kódexekhez hasonlóan - egy-egy ősnyomtatvány-kiadás akár minden egyes példánya teljesen egyedivé válhatott. A kötetek e díszek, továbbá a kézmüves gótikus és/vagy reneszánsz bőrkötések, azaz egyedi jellegzetességeik révén különböznek egymástól - bár ugyanabból a nyomdából kikerült, ugyanazon kiadású művek voltak.

${ }^{6} \mathrm{~A}$ többi megjelenéssel kapcsolatos adatsor (szerző, cím, nyomdász, megrendelő, nyomtatási hely és idő) a nyomtatványok végére, az úgynevezett kolofonba került elhelyezésre. Az ősnyomtatványok azonosítását jelentősen megnehezíti az a tény, hogy mintegy egyharmadukból hiányzik a kolofon.

${ }^{7}$ A kézi sajtó korában később a hajtogatott íveket ettől eltérően folyamatosan egymás mellé helyezték. Az ősnyomtatványoknak általában nincs lapszámozásuk, az ívfüzeteket viszont jelzésekkel látták el; legáltalánosabban az abc betűivel. A leveleket az ívfüzet közepéig római számokkal jelölték. A levelek és az ívek sorrendjét a lap alján őrszó (custos) jelezte. A nyomtatványok legtöbbjének végén úgynevezett registrum található, amely útmutatót jelent az ívfüzetek sorrendjére vonatkozóan. A registrum terjedelme idővel lerövidült, végső változatában már csupán az ívfüzetek terjedelmét közölték benne (például: „omnes sunt quaterni, praeter c, e, f, g, qui sunt quinterni”). Egyes területeken az ilyen jellegü registrum nem terjedt el, helyette - például a német nyelvterületen - a tartalomjegyzéket vagy a névmutatót nevezték registrumnak.

${ }^{8}$ Címleírásuk teljesen eltér a „modern” könyvekétől: egy-egy ősnyomtatványról általában kétféle címleírás készül, egy rövid és egy teljes, az előbbinél jelentősen hosszabb. A teljes címleírás tartalmazza a szerző nevét, általában középkori formában, elöl a keresztnévvel. A szerzős ősnyomtatványok jelentős részében nem tüntették fel a szerző nevét, ezt gondos odafigyeléssel és utánakereséssel lehet és kell megállapítani. A címek lehetnek rövidek vagy néha bőbeszédủen hosszúak. A felvétel során ezért az irodalomtörténetileg elfogadott cím-alak a mértékadó, mindenféle zárójel alkalmazása nélkül. Ez az alak esetenként egybeesik, azonos a köteten megtalálható címmel. Az impresszumadatok megszokott sorrendje (hely, nyomdász, év), esetenként kiegészül a kiadó nevével (a „pro" és az „impensis” megjelöléssel együtt). A terjedelem levélszámozással adható meg, melyet kiegészíthet a kollacionálás. A teljes leírás második részében betúhíven kell visszaadni a nyomtatvány címlapját, továbbá a nyomtatást tartalmazó első lapnak és a tulajdonképpeni szövegnek az első sorait, a második ívfüzet első sorát, valamint a kolofont. Minden esetben jelezni kell a példány csonkaságát, kézira- 
tói szempontokat is érvényesíteni. Így elsősorban fontosnak tünik megkeresni és rendszerezni mindazokat az ,iratokat”, melyekben a konkrét müről érdemleges módon szó esik - például hasznos megvizsgálni a kötet használatát, eladásátmegvételét, ajándékozását és hagyományozását. ${ }^{9}$

\section{A legkorábbi Magyarországon készült ősnyomtatványok}

Jelenlegi ismereteink szerint nincs teljes terjedelmében magyar nyelvü ösnyomtatvány. A XVIII. század végén Bartalis Antal jegenyei plébános ugyan birtokolni vélt egy 1484-ben Nürnbergben kiadott magyar nyelvü nyomtatott éneket oratióval együtt Szent István király jobb kezéről, s ezt a Régi Magyarországi Nyomtatványok $(R M N y)$ első kötete - Szabó Károly hungaricum bibliográfiája első kötetét követve - függelékben (App. 4) közli is, de a bibliográfia - ugyanitt - a „nyomtatványra” vonatkozó szakirodalmat kronologikusan áttekintve, ezt a tételt „tévesen feltételezett"-nek minősítette. ${ }^{10}$ Az első Magyarországon kinyomtatott könyv latin

tos bejegyzéseit, díszítését és kötését. A megjegyzésben érdemes feltüntetni a müre vonatkozó fontosabb irodalmat is. Az ösnyomtatványokat több, általában három-négy mértékadó ősnyomtatvány bibliográfiában szükséges behasonlítani. A kolofon nélküli ösnyomtatványok (az ösnyomtatványok mintegy egyharmad része) azonosításakor az egyes ősnyomdászokra jellemző betüfajták elkülönítése jelentheti a segítséget. Erre vonatkozóan Konrad Haebler (elődei, Henri Brodshaw és Robert Proctor munkáját felhasználva) megnyugtató tudományos módszert dolgozott ki. A legváltozatosabban metszett gót betüt, az 'M'-et alapul véve típusrepertóriumot dolgozott ki, s az 'M' 101 alapformáját különítette el. Ezt kiegészítette a sorok nagyságával, húsz sor méretét alapul véve. A kolofon nélküli ösnyomtatványok esetében először az 'M' betüt kell meghatározni, majd lemérni a húsz sor távolságát és a két adatot be kell hasonlítani a típusrepertóriumban. A vizsgálatot érdemes kiegészíteni az így meghatározott nyomdász egy másik ismert és már biztosan azonosított müvével történő összevetéssel. A nem gót betűs, kolofon nélküli ősnyomtatványok azonosítása az előbbinél nehezebb feladat, mivel az antikva betúknél sokkal kevesebb az egymástól való eltérés. Itt kiindulópontként a 'Qu' betü szolgál. Az így létre hozott antikva-repertórium a különleges formákkal együtt összesen húsz 'Qu' formát különít el, s ehhez megadja a 'h', az 'y' és néhány különleges, a nyomtatásban alkalmazott jel sajátosságát. A típus-meghatározás alapján következtetést lehet levonni a nyomtatvány keletkezési idejére is. Ez a módszer általában pontos eredményeket biztosít 1480 körülig. Később, mivel az egyes ősnyomda-mühelyek megvásárolták egymás betükészletét, azokat többnyire átöntötték, s ennek következtében a sorméretek általában néhány milliméterrel megváltoztak, nehezebb a meghatározás. A lehetőség szerinti minél nagyobb pontosságra törekedve érdemes a vizsgálatot a vízjelek figyelembevételével és a nyomdák egyéb kiadványaival történő összevetésekkel kombinálni.

${ }^{9}$ Az így elökerült források segítséget nyújtanak a könyvtörténeti sajátosságok megfogalmazására, melyek kiterjedhetnek a kor írásbeliségére, a könyvek kiadására és forgalmazására, iskola- és művelődéstörténeti következtetések levonására. Ezek a szempontok - következetesen érvényesítve - összekapcsolhatók más jellegü kutatásokkal, s segítségükkel lehetőség nyílik az ősnyomdászat korának eruditív mủveltségére, az európai szellemi áramlatok kölcsönhatására vonatkozó újabb és újabb megfigyelések megfogalmazására.

${ }^{10}$ Ismételten áttanulmányozva az e „cantilená”-ra vonatkozó kibővített, jelenleg hozzáférhető teljes forrásanyagot, megállapíthatóvá vált, hogy a jegenyei plébános tulajdonában nem egy 1484-ben megjelent ritka nyomtatvány volt, hanem néhány füzet a Szentjobb ereklyéről nagy példányszámban 1771-ben megjelent füzetes kiadványokból. Bartalis a XVIII. század végi általánosan divatos szövegarchaizálásokhoz hasonlóan megtévesztő módon archaizálta egy ilyen füzet 
nyelvü. Ez a Chronica Hungarorum (GW 6686), amelyet - jelenlegi ismereteink szerint - egy Rómából Magyarországra hívott német nyomdász (akinek személye ma is ismeretlen), Andreas Hess nyomtatott 1473-ban. ${ }^{11}$

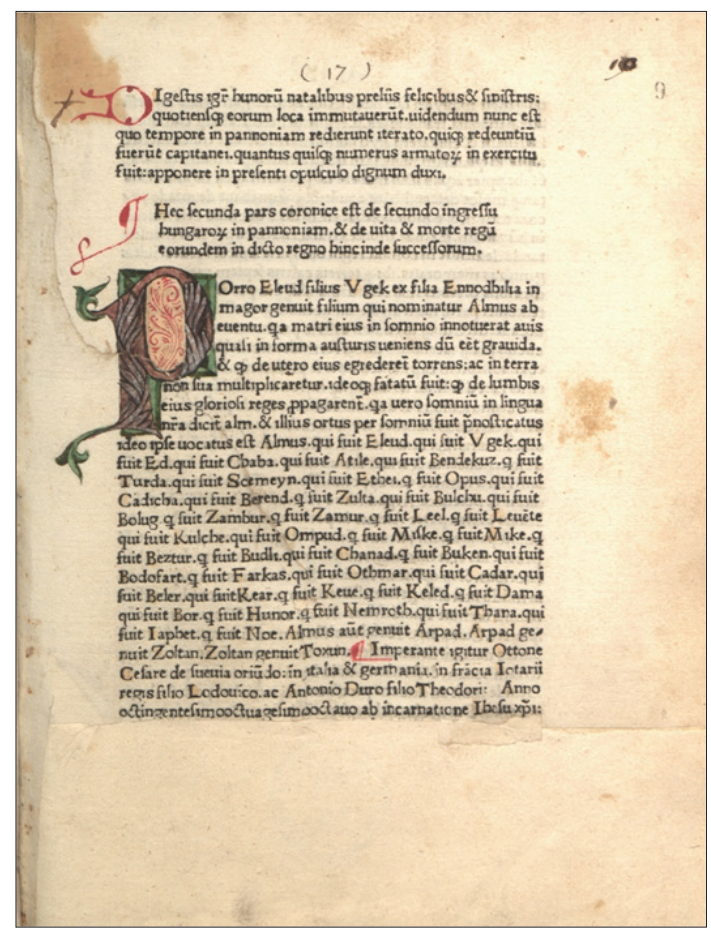

4. kép. Chronica Ungarorum, Buda, Andreas Hess, 1473, 9r

néhány sorát, s ezzel igyekezett egy újabb régi magyar nyelvemléket „létrehozni”, azaz koholni. Vö. Knapp Éva: Egy tévesen feltételezett 1484-es magyar nyelvü nyomtatvány eszmetörténeti kapcsolatai a XVIII. század végén. = Uö., Libellus. Válogatott könyv-és könyvtártörténeti tanulmányok, Budapest, Balassi Kiadó, 2007. 247-272.

${ }^{11}$ A címlap nélküli, Andreas Hess ajánlásával kezdődő („Ad [...] Ladislaum, praepositum ecclesiae Budensis, prothonotarium apostolicum, necnon vicecancellarium [...] regis Matthiae") kiadvány Magyarország történetét tartalmazza. Egyrészt a XIV. században szerkesztett magyar krónika egy változatát, másrészt ennek kibővítését a nyomtatás idejéig történt eseményekkel. Két fö részből áll, az első huszonnégy fejezetben a hunok történetét, a második kettőszáznegyvenhat fejezetben a magyarok történetét beszéli el, mindegyik elején tartalomra utaló cím olvasható. A Budán, 1473 pünkösdjén Hess Andrást sajtója alól kikerült első Magyarországon nyomtatott könyvvel a magyar ősnyomdászat több országot is megelőzött, mert például Skandináviában vagy Angliában ennél később indultak az első ősnyomdák. A Hess-nyomda valószínűleg az azon a helyen álló egykori épületben müködött, ahol ma a budai várban tér örzi a nevét. A Chronica Hungarorumból jelenleg összesen tíz példány ismert, ezek közül mindössze kettőt őriz magyarországi közgyüjtemény, egyet az Országos Széchényi Könyvtár, egy másikat a budapesti Egyetemi Könyvtár (ELTE Egyetemi Könyvtár). A nemzetközi ősnyomtatvány irodalomban Michael Maittaire tett először 1733ban említést a nyomtatványról az Annales typographici (IV, Amsterdam, 331) címü munkájában. 
A Hess-nyomda egy másik budai terméke is fennmaradt 1473-ból (Leonardi Aretini in opusculum Magni Basilii de legendis poeticis incipit feliciter, GW 3702) ennek megjelenése után azonban a tipográfia valószínúleg beszüntette tevékenységét. ${ }^{12}$

A második magyar ősnyomda 1477-1480 között múködött. Jelenleg négy itt készült nyomtatványt tart számon a szakirodalom (RMNy 3, 4, 5, 6). A nyomdáról még ma sincs semmiféle bővebb ismeret, elnevezése az egyik fennmaradt, itt készült mü címéből Typographia Confessionalis. ${ }^{13}$ Itt készült Laudivius Szent Jeromos életrajza is, melyből a világon jelenleg kizárólag a budapesti Egyetemi Könyvtár öriz példányt. ${ }^{14}$

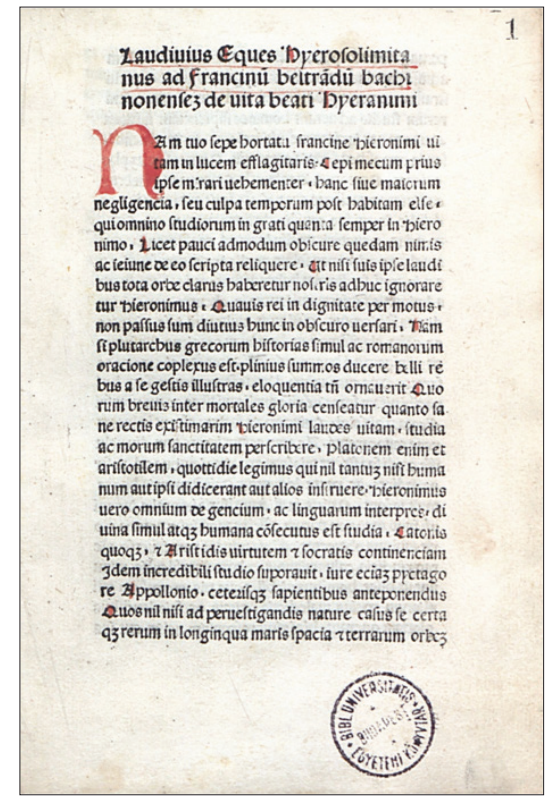

5. kép. Laudivius Zacchia, Vezzanensis, Vita beati Hieronymi, [In Hungaria, Typographia Confessionalis, 1477-1480?], 1r Inc 862

${ }^{12}$ Ez a címlap nélküli, negyedrét alakú, húsz levél terjedelmủ munka erkölcsbölcseleti értekezéseket tartalmaz. A nyomtatványban Basilius Magnus A fiatalokhoz címü müvének latin fordítása és Xenophon Szókratész védőbeszéde (szintén latin nyelven) olvasható. A szakirodalom ezt a munkát tartotta hosszú ideig az első magyarországi ősnyomtatványnak, Fitz József azonban a Chronica Hungarorum előszavából megállapította, hogy a krónika volt valójában az első magyar földön kinyomtatott mü (Fitz József, Hess András, a budai ösnyomdász, Budapest, 1932. 132.).

${ }^{13}$ A nyomda müködéséhez kapcsolódik egy gyóntatói kézikönyv (Antoninus Florentinus, Confessionale GW 2108, RMNy 3), egy egykorú adat alapján feltételezhető német nyelvü politikai röpirat (RMNy 4).

${ }^{14}$ További nyomtatványok e műhelyből: és egy, Johannes Han pozsonyi plébános nevének (aki a török elleni háború támogatására hirdetett búcsú egyik biztosa volt) feltüntetésével búcsú engedélyezését igazoló nyomtatvány, egy búcsúlevél ürlap (egyetlen példányát Pozsonyban - Vedecká knižnica mesta Bratislavy - őrzik, RMNy 6). 


\section{Ősnyomtatványok a budapesti Egyetemi Könyvtárban - (ELTE Egyetemi Könyvtár) különös tekintettel országos unikum példányokra}

A könyvtár jogelödje, az első nagyszombati jezsuita könyvtár megalapításával (1561) és e könyvtár jogutódai révén jött létre az az országban egyedülálló ősnyomtatvány-gyüjtemény, mely évszázadokon át egészen a mai napig együtt maradt és folyamatosan bővült. A tár kiemelkedő jelentőségű abból a szempontból is, hogy állományát nem magángyüjtemény formájában, látványosságként gyüjtötték össze, hanem napi használatra, elsősorban oktatásra és tanulásra szánták. Fő jellegzetessége, hogy az eredeti állományt évszázadokon keresztül megőrizte a gyüjtemény. Ezt az állítást elsősorban a kötetekben megtalálható viszonylag sok bejegyzés, marginália bizonyítja. A tár történetére vonatkozó két fó forrás a kötetekben található egykori tulajdonosi bejegyzéseken kívül a könyvtár fennmaradt XVII. századi történeti katalógusai. A legrégebbi ősnyomtatvány-beszerzések az 1561 utáni évekből származnak. ${ }^{15}$ A gyüjteményt bővítő egyik nevezetes ősnyomtatványban, Thuróczi, Chronica Hungarorumában a következő bejegyzés olvasható: „donatus a Francisco Zabo 1590” - „Inscriptus Collegij Turociensis Societatis Jesu”.

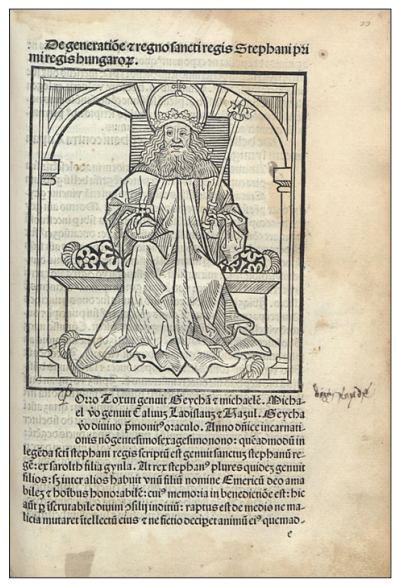

6. kép. Thuróczy János, Chronica Hungarorum, Brno, Konrad Stahel et Matthias Preinlein, 1488; Inc. 338

${ }^{15}$ Az ősnyomtatványok száma a könyvtár történetének kezdetétől folyamatosan gyarapodott. Dümmerth Dezső kutatási eredményét elfogadva, mai ismereteink szerint egy ösnyomtatvány (Inc. 256, Marcus Tullius Cicero, Epistolae ad familiares, Velence, 1487, A. de Paltaszichis - korábban egybekötve egy XVI. századi Cicero, Epistolae ad familiares, Párizs, 1557, apud Audoëneum Parvum, kiadással, Ant. 4297) a könyvtár legrégebben, 1586-1589 között beszerzett és máig folyamatosan használt és megörzött kötete. Ez az egyik jogelőd könyvtárban, Turóc-Znióváralján (ma Kláštor pod Znievom, Szlovákia) már használt kolligátum a jezsuita oktatásban a XVI. századi kezdetek óta Európa-szerte használt tankönyvnek számított. Legkorábbi tulajdonosi bejegyzése: „Societatis Jesu inscriptus Catalogus - Collegium Turocensis”. Később Vágsellyén egy újabb tulajdonosi bejegyzést írtak a kötetbe: „An[no] 1600. Selliensis”, melyet az egyetemalapítást megelözően követett a „Tyrnaviensis 1632”. 
$\mathrm{Az}$ ismeretlen nagyszombati Szabó Ferenc városi polgárt egy ismertebb nevezetes személy követi újabb ajándékozóként, Partinger Gáspár, aki nagyszombati városi tanácstag volt, s öt ősnyomtatvány kötettel, Nicolaus de Lyra ötkötetes Biblia-kommentárjával gazdagította 1616-ban az állományt. ${ }^{16}$

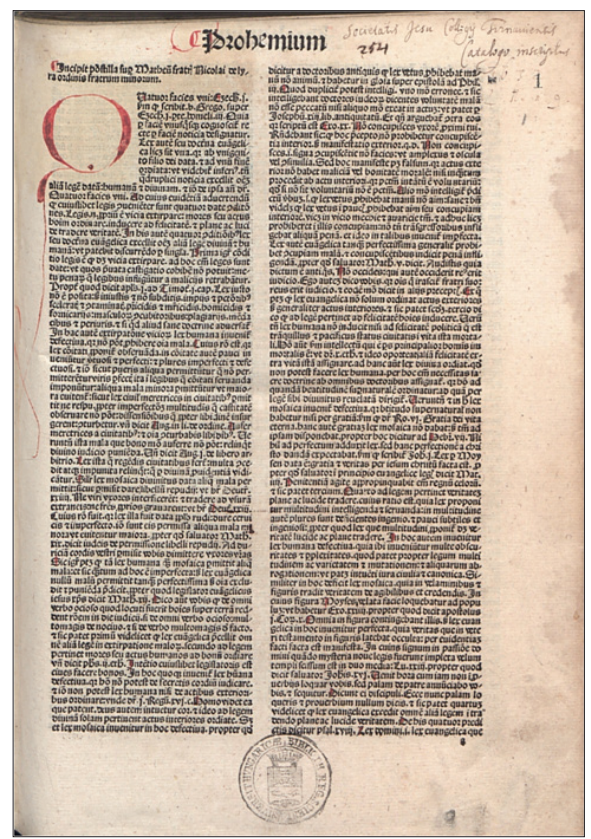

7. kép. Biblia, Nürnberg, 1485, 1r Inc274

Ezt az első hat ősnyomtatványt továbbiak követték a nagyszombati egyetem megalapításáig (1635). ${ }^{17} \mathrm{Az}$ egyetem megalapítása előtt a gyüjteménybe bekerült teológiai és egyházjogi ősnyomtatványok mellett matematikai munka (Claudius Ptolomaeus, Quadripartitum cum aliis tractatibus) éppúgy megtalálható, mint az 1633-ban beszerzett, a második magyarországi ősnyomdából kikerült Antoninus Florentinus Confessionaléja.

${ }^{16}$ Ennek a Biblia. Cum postillis Nicolai de Lyra [...] (Nürnberg, Anton Koberger, 1487) címú münek a címlapján első bejegyzésként az „Ex dono Dominij Caspari Partingeri Collegij Soc[ieta]tis Jesu Tyrnaviae 1616" szerepel, melyet a máig fennmaradt, legkorábbi nagyszombati kéziratos katalógusra történő utalás követ, az „Inscriptus Catalogo 1632. L[ittera] N. n[umero] 6. 7. 8. 9” formában.

${ }^{17}$ Közülük a legrégebben megjelent nyomtatvány Franciscus de Platea Opus restitutionum usurarum et excommunicationum (Padova, Leonardus Achates, 1473) címü munkája volt, melyet az első fennmaradt könyvtári katalógusban a „Francisci de Platea Opus restitutionum in folio corio rubro Paduae 1473” formában örökítettek meg. Jelenleg ebből a kiadásból a könyvtár nem öriz példányt, az egyetlen magyarországi példány a Magyar Tudományos Akadémia Könyvtárában található meg (jelzete ott: Inc. 518). Időben ezt követi Szent Ágoston De civitate Dei című művének két velencei kiadása (Gabriele di Pietro, 1475 - Inc. 25; Bonetus Locatellus, 1486/1487 - Inc. 221). 


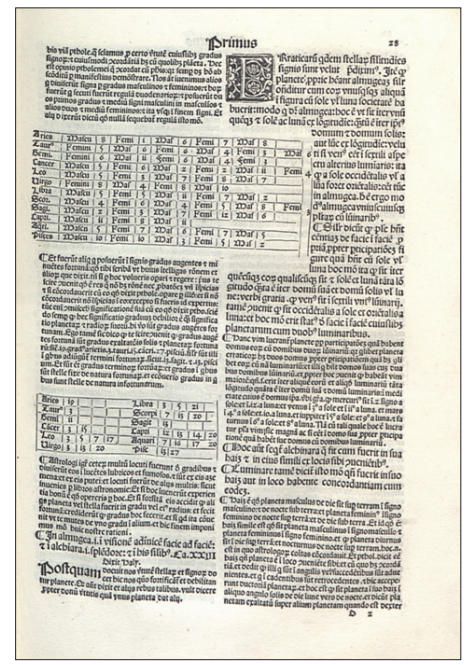

8. kép. Klaudios Ptolemaios, Quadripartitum, Venezia, 1493, 28r Inc 487

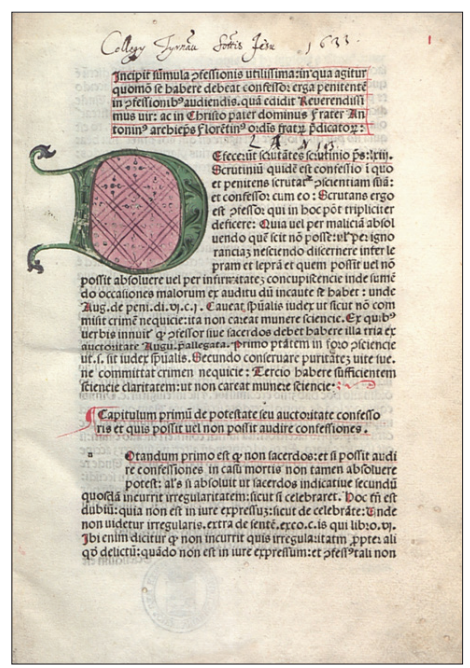

9. kép. Antoninus Florentinus, Confessionale, [In Hungaria, 1477], Ir Inc 46

Utóbbinak a tulajdonosi bejegyzése a címlapon „Collegij Tyrnau[iensis] So[cie] t[a]tis Jesu 1633. L[ittera] A. N[umero] 193," s e nevezetes példány mellett egy másik, variáns példányt is őriz a kiadványból a könyvtár. ${ }^{18}$

${ }^{18}$ Antoninus Florentinus firenzei érseknek e XV. század közepén készült műve gyóntatói segédkönyv, melynek több mint száz különböző ősnyomtatvány-kiadása ismert. Fitz József és Soltész Zoltánné kutatásai tették nyilvánvalóvá, hogy a fenti példányok és egy további, Gyöngyösön örzött példány a Magyarországon 1477-1480 között müködött második hazai ősnyomda terméke, s azt nem Nápolyban nyomtatták Matthias Moravus tipográfiájában. 


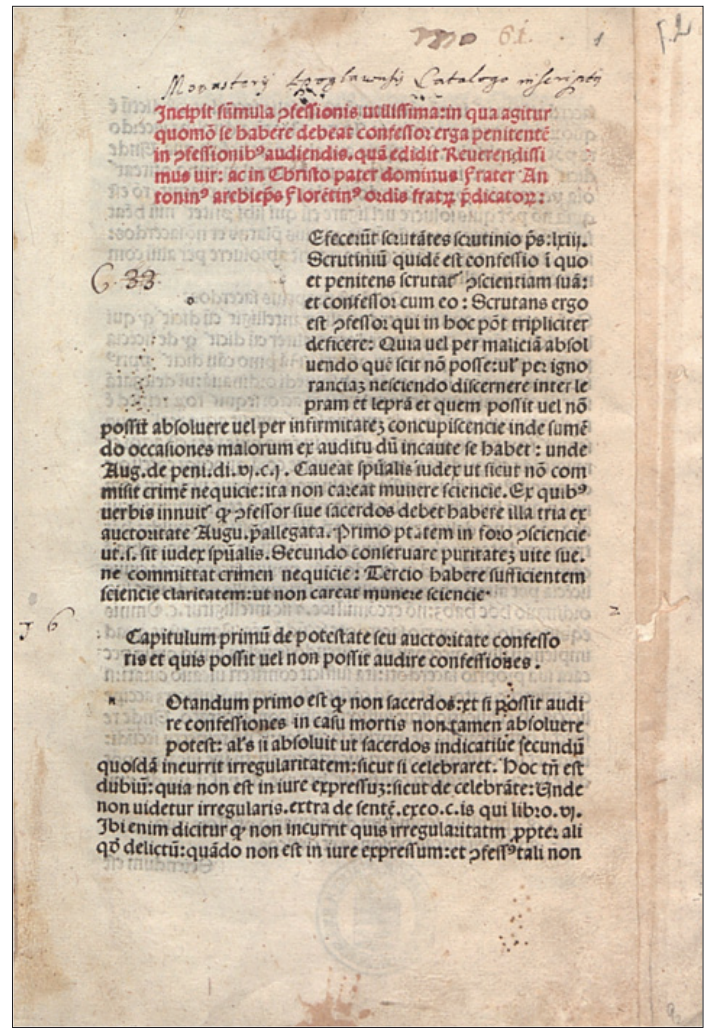

10. kép. Antoninus Florentinus, Confessionale, [In Hungaria, 1477], 1r Inc 45

1635 előtt összesen huszonhat ősnyomtatványt ôrzött a nagyszombati jezsuita könyvtár, melyek közül húsz ma is a gyüjtemény része. Valószínü, hogy két továbbit is őriz a könyvtár, de ezeknek időközben megsérült a tulajdonosi bejegyzése. Azaz az ősnyomtatványtár legrégebbi huszonhat kötetéből huszonkettőt közel 380 éve öriz a könyvtár.

A nagyszombati jezsuita egyetem megalapítását követően további ősnyomtatványokkal gyarapodott az állomány. ${ }^{19}$ Kiemelem közülük az 1681-ben beszerzett Euklidesz Elementa geometriát.

${ }^{19}$ 1637-ben Armandus de Bellovisu De declaratione difficilium terminorumát (Basel, 1491 - Inc. 418), 1690-ben Petrus Lombardus Sententiarum libri quatuor-ját (Nürnberg, Anton Koberger, 1491 - Inc. 424) és Michael de Dalen Casus brevies Decretaliumát (Strassburg, Georg Husner, 1493 - Inc. 470), 1692-ben Cassiodorus zsoltármagyarázatait (Cassiodorus Senator, Flavius Magnus Aurelius, Expositio Psalterii, Basel, Johann Amerbach, 1491 - Inc. 425) szerezték be. Plinius Historia naturalisának 1491-ben megjelent velencei kiadása (Inc. 432) a nagyszombati jezsuita kollégium által megszervezett egyik Mária kongregáció könyvtárából került a jezsuita könyvtárba (az ajándékozó bejegyzés szerint Szomori Mátyás adta a kötetet a kongregációnak 1655-ben: „Sodalitatis B[eatae] V[irginis] Visitantis in Collegio Soc[ietatis] Jesu Tyrnav[iensis] 1655 dedit Dominus Mathias Szomori”). 


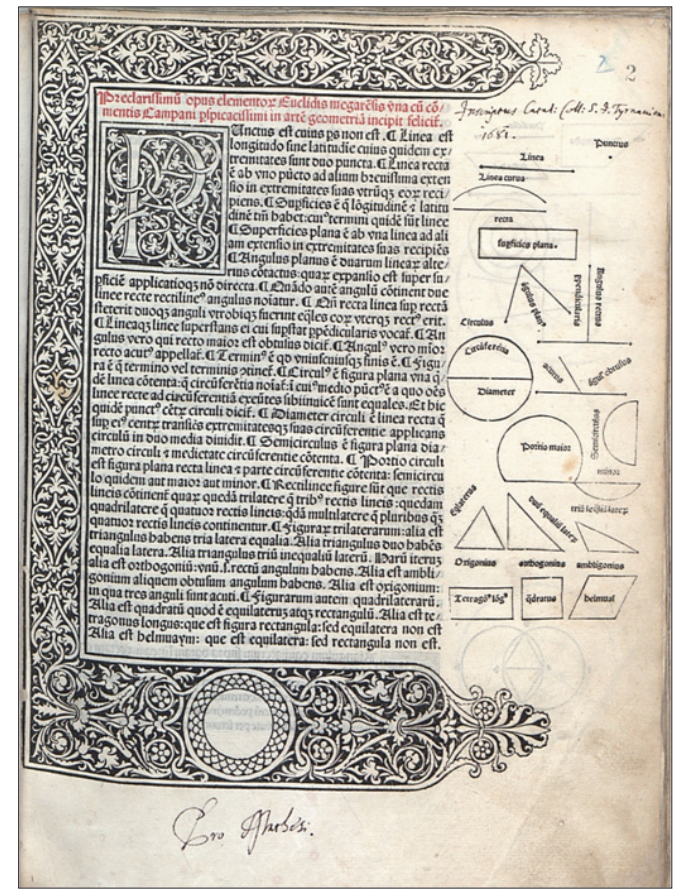

11. kép. Euklides, Elementa geometria, Venezia, 1482, 2r Inc115

A jezsuita rend feloszlatásáig (1773) folyamatosan gazdagodott a könyvtár állománya ősnyomtatványokkal, ezek kivétel nélkül használati könyvként és nem célzottan megvásárolt ritkaságként kerültek a gyüjteménybe. Az ösnyomtatványtár legjelentősebb állomány-növekedése Mária Terézia, majd II. József szerzetesrendeket feloszlató rendeleteinek köszönhető. A feloszlatott rendi könyvtárakból az uralkodó a bécsi udvari könyvtár elsőbbségének biztosítása után válogatási jogot adott a volt nagyszombati jezsuita egyetem könyvtárának államosítása után Budára, majd Pestre költöztetett egyetemi könyvtárnak. A könyvtár a Magyarországon használt ősnyomtatványok jelentős részének lett a gyüjtőhelye, több ritkaság is ezen az úton került be a könyvtári állományba. ${ }^{20} \mathrm{Az}$ ősnyomtatványok állományadatát a XVIII. század utolsó negyede végén csak megközelítően lehet megbecsülni. Vértesy Miklós kutatásai alapján tudjuk, hogy a rendelkezésre álló források közül a kötetekben ma is megtalálható tulajdonosi bejegyzések alapján a nagyszombati volt jezsuita könyvtári ősnyomtatványokon kívül 223 ősnyomtatvány egykori őrzőhelye volt jezsuita gyüjtemény. Ezek megoszlása a proveniencia szerint a következő.

${ }^{20}$ Ilyen például a Diurnale Argentinense (Basel, Michael Wenssler, circa 1491 - Inc. 830), melyből a Gesamtkatalog der Wiegendrucke mindössze öt példányt tart számon, s ezek között a budapesti Egyetemi Könyvtár példánya variáns példány. 


\begin{tabular}{|l|c|}
\hline \multicolumn{1}{|c|}{ Hely } & Kötetek száma \\
\hline Besztercebánya & 26 \\
\hline Eperjes & 15 \\
\hline Fiume & 12 \\
\hline Komárom & 10 \\
\hline Lőcse & 1 \\
\hline Pozsony & 87 \\
\hline Selmecbánya & 2 \\
\hline Sopron & 28 \\
\hline Szakolca & 3 \\
\hline Szatmár & 2 \\
\hline Szepes & 5 \\
\hline Trencsén & 4 \\
\hline Turóc & 3 \\
\hline Zsolna & 2 \\
\hline Bécs, Pazmaneum & 9 \\
\hline Egri egyházmegye bécsi & 11 \\
S. J. papnevelde & 1 \\
\hline Krems & 2 \\
\hline Triest & \\
\hline
\end{tabular}

A táblázatból nyilvánvaló, hogy a pozsonyi, a soproni és a besztercebányai jezsuita könyvtárakból került a legtöbb ősnyomtatvány az államosított nagyszombati egyetem könyvtárába. A jelentős számú pozsonyi gyarapodás oka elsősorban abban kereshető, hogy e jezsuita könyvtár örizte Mossóczi Zakariás nyitrai püspök XVI. századi gazdag magánkönyvtárának jelentős részét. ${ }^{21}$ Egy másik Vértesy által számba vett forrás Pray György Index rarioruma (I-II. kötet, Buda, 1780-1781). Pray összesen 179 ősnyomtatványt vett be munkájába, közülük 88 kötetben található egykori jezsuita tulajdonosi bejegyzés. Ha e két, eltérő forrásból származó adathoz becslés alapján (30-40 kötet) hozzáadjuk a Pray által kihagyott ősnyomtatványokat, illetve a tulajdonosi bejegyzést nem tartalmazó egykori jezsuita könyvtárakban őrzött XV. századi nyomtatványokat, az állományt 350 kötetre lehet becsülni.

A II. József által elrendelt rendfeloszlatások (1782-1786/88) következtében a feloszlatott 134 férfi és 6 női rendház könyvtárának állománya állami tulajdonba került. Vértesy András áttekintette a gyüjteménybe ekkor bekerült

${ }^{21}$ Ismeretes, hogy Mossóczi 1587-ben sógorára, Kecskés Andrásra hagyta könyvtárát, akitől Kecskés János nagyszombati kanonokhoz került. Kecskés János saját könyvgyüuteményével együtt a pozsonyi jezsuitáknak ajándékozta el a Mossóczi-féle könyveket. 
ősnyomtatványok utolsó tulajdonosait, s megállapította, hogy a bejegyzések és a beragasztott exlibris-eket figyelembe véve az ősnyomtatványok a következő rendektől származnak. ${ }^{22}$

\begin{tabular}{|l|c|}
\hline Szerzetesrend megnevezése & Ősnyomtatványok száma /kötet \\
\hline pálos & 208 \\
\hline minorita + ferences & 23 \\
\hline trinitárius & 11 \\
\hline szervita & 12 \\
\hline premontrei & 6 \\
\hline karmelita & 2 \\
\hline bencés & 4 \\
\hline
\end{tabular}

Teljes egészében egyedül a pálos rend könyvállományából származó ősnyomtatványok találhatók meg a könyvtárban (208 kötet). Ezek egykori rendházankénti megoszlása - szintén Vértesy András nyomán - a következö.

\begin{tabular}{|l|c|}
\hline Pálos rendház & Ősnyomtatványok száma /kötet \\
\hline Csáktornya & 25 \\
\hline Felsőelefánt & 24 \\
\hline Lepoglava & 49 \\
\hline Máriavölgy & 20 \\
\hline Nagyszombat & 8 \\
\hline Novi & 11 \\
\hline Pest & 31 \\
\hline Remete & 11 \\
\hline Többi, kisebb rendházból összesen & 29 \\
\hline
\end{tabular}

Az ősnyomtatványok korábbi tulajdonosainak figyelembevételével megrajzolhatóvá válik minden egyes, a gyüjteményben megőrzött ősnyomtatvány története.

A II. József kori abolició után a könyvtár ősnyomtatványainak száma becslés alapján - mintegy hatszáz kötet lehetett. Ez a mennyiség és a kötetek által képviselt minőség (a ritka és unikum példányok révén) egyedülálló volt az országban. Így például a legértékesebb, 1470 előtt készült ősnyomtatványok száma négy (Inc. 789, 790, 867, 872). II. József 1785-ben rendeletet adott ki

${ }^{22}$ A táblázatba foglalt adatok az egykori valóságot nem minden részletükben tükrözik, mivel egyrészt léteznek a kötetekben úgynevezett ,rejtett” tulajdonosi bejegyzések is, másrészt például a pannonhalmi bencés apátságból beszállított ősnyomtatványok a könyvtárból számba vett négy kötet kivételével visszakerültek Pannonhalmára. Az adatokat az is torzítja, hogy egyes szerzetesrendek nem minden feloszlatott rendházából kerültek be az Egyetemi Könyvtárba az ősnyomtatványok. 
az abolició révén bekerült másod- és többes példányok értékesítésére. ${ }^{23}$ Ezeken az árveréseken négy ősnyomtatványt kínált megvásárlásra a könyvtár, ${ }^{24}$ közülük egy, Jacobus Sprenger és Henricus Institoris híres, a boszorkányperek lefolytatói számára írt kézikönyvének, a Malleus maleficarum (Nürnberg, Anton Koberger, 1496, H *9246) többes példánya biztosan elkelt, harminc krajcárért. ${ }^{25}$

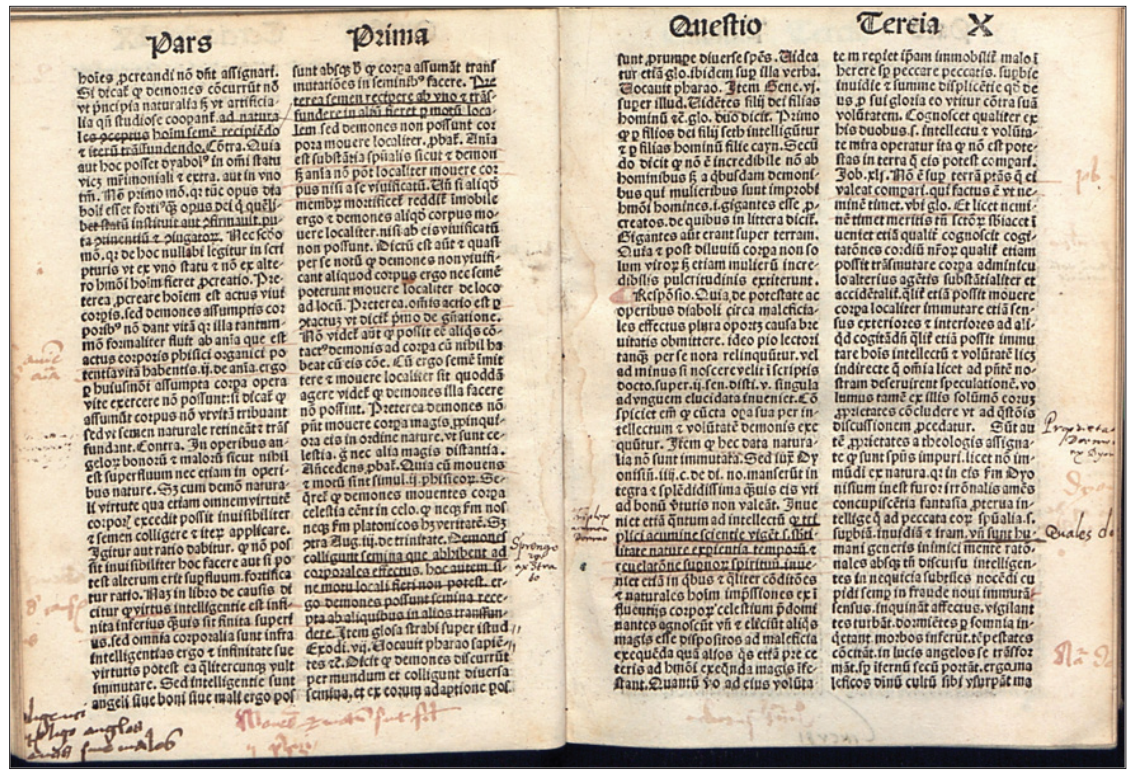

12. kép. Malleus maleficarum, Nürnberg, 1496, Inc591

A könyvtár ősnyomtatványai csak 1875 után kaptak egyedi jelzetet, amikor befejeződött az átköltözés a mai épületbe. A XV. századi nyomtatványok leválasztását az állományból, önálló gyüjteménnyé rendezését és katalogizálását Kudora

${ }^{23}$ A rendelet végrehajtása során 1787-1797 között hét árverést rendezett az Egyetemi Könyvtár és összesen 20.031 könyvet kínált eladásra, mely a további többes példányok figyelembevételével mintegy 25.000 kötet lehetett. Az árverések nyomtatott katalógusai (Catalogus librorum, gui in Bibliotheca Universitatis Pestiensis publicae auctioni exponentur, [hét füzet], Pest, 1778-1797) a könyvtár történetének becses forrásai, kutatásuk még éppen csak elkezdődött.

${ }^{24}$ Hain-számokkal kifejezve ezek a következők: H 3118, H 1249, H 5388, H 9246.

${ }^{25}$ A későbbi időszakban - annak ellenére, hogy 1802-ben I. Ferenc rendeletére a szerzetesrendek részleges visszaállítása megtörtént, s e rendelet végrehajtási utasítása kötelezte az Egyetemi Könyvtárat a biztosan megállapítható korábbi tulajdonjog alapján a könyvek visszaállított rendeknek történő visszaadására - még két árverést $(1806,1826)$ tartottak a könyvtár állományából. Az 1806-ban eladásra kijelölt ősnyomtatványt (H 8562), Szent Jeromos leveleinek 1495. évi nürnbergi kiadását nem vásárolták meg, a müből jelenleg két példányt őriz a könyvtár (Inc 547, 548). 1826-ban összesen tizenkét ősnyomtatványt adtak el, melyekből tizenegyet megvásároltak. Utóbbiakat a híres gyüjtő Jankovich Miklós (három kötet), a könyvtár első őre, Veszerle József (négy kötet) és J. B. Redl (négy kötet) szerezte meg. 
Károly végezte el 1881-ig. ${ }^{26}$ 1901-ben történt meg a tár újrarendezése. Dedek Crescens Lajos 1-960 sorszámmal jelzetelte a gyüjteményt (953 mü $=972$ kötet), melyben hét szám üresen maradt. ${ }^{27}$ A nyomdakész katalógust 1907 óta szerette volna kiadatni Ferenczy Zoltán igazgató, ezt azonban meghiúsította az I. világháború, s a kézirata ma lappang. A tár állománya 1945-ig további mintegy 110 kötettel gyarapodott, ezek jelentősebb része a már meglévő könyvtári állományból mint datálatlan (keltezetlen) nyomtatvány került elő. Az 1946 utáni beszerzésekkel együtt az 1949. évi revízió szerint a tár állománya 1089 kötet volt. Az 1949-1964 között vásárolt tizenhárom ősnyomtatvány a vétellel történő gyarapodások között jelentősnek számít. Gyarapodott az ősnyomtatványok száma az Országos Könyvtárügyi Tanács állománygyarapítási és könyvforgalmi szakbizottságának 1960. VI. 30-án hozott döntése alapján is, mely szerint az ösnyomtatványok szétosztásánál elsőként a nemzeti könyvtár, másodikként az Egyetemi Könyvtár igényelhet az 1952-1954 között állami tulajdonba vett 1500 előtt készült nyomtatványokból. E döntés alapján tizenegy kötettel bővült a tár 1962. decemberig. A gyarapodás lényegében azóta is folyamatos, bár nagyon lassú a beszerzés anyagi nehézségei miatt.

A könyvtár jelenleg az 1200-nál több bibliográfiai egységet őrző ősnyomtatványával Magyarország harmadik legnagyobb incunabulum-gyüjteménye. Több olyan kötettel bír, amely ezeknek a kiadásoknak az egyetlen ismert példánya. ${ }^{28}$ Kiemelkedő jelentőségüek azok az ősnyomtatványok - így például a

${ }^{26}$ Tervbe vették e katalógus nyomtatott megjelentetését, ami azonban kétszer is elmaradt az újabb ősnyomtatványok elökerülése miatt.

${ }^{27}$ A katalógus alapján a XVIII. század vége óta jelentősen tovább bővült az állomány, összesen 972 ősnyomtatvány kötetet tartottak ekkor számon, melyhez hozzá kell számolni még kb. 40 datálatlan, később a gyüjteménybe sorolt kötetet.

${ }^{28} \mathrm{Az}$ ösnyomtatványok jelzete - más hazai ősnyomtatvány-gyüjteményekhez hasonlóan - az 'Inc' rövidítésböl és numerus currens arab számból áll. Az ösnyomtatványok úgynevezett rövid címleírása ma már elektronikus formában is elérhető, s a könyvtár tervbe vette a könyvészeti leírások bővített formátumú, a kötetek egyéni jellegzetességeire is figyelö leírások elkészítését. Utóbbit mindez ideig erőteljesen nehezítette egy, a tár egészét jellemző sajátosság, a kötetek hosszú időszakot átívelő intenzív használtsága miatt a hiányos példányok sokasága. A nagyon sok esetben, szinte általában hiányzó első és utolsó levelek, sérült könyvtestek, töredékesen fennmaradt lapok éppúgy lelassítják az azonosítást, mint a bővített feldolgozást. Ugyanakkor a köteteknek ez a sajátos állapota nem véletlenszerü, hanem a korszakokon át tartó folyamatos, általában oktatási vagy tanulási tevékenység következménye. Ez az utóbbi körülmény ugyanakkor különösen becsessé teszi a gyüjteményt, mivel az egyes kötetek nem csupán könyv- és könyvtártörténeti jelentőségüek, hanem oktatás- és müvelődéstörténeti sajátosságokat is hordoznak. E sajátosságok jelentős része a gyüjteménybe kerülés (proveniencia) tényével kiegészítve új kontextusba helyezik a tár egészét, s együttes megközelítésük országos történettudományi, irodalomtörténeti és pedagógia-történeti érdeklődésre tarthat számot. A gyüjtemény történetét - mint arról már esett szó - Vértesy Miklós foglalta össze tizenhét oldalon 1964-ben (Az Egyetemi Könyvtár ösnyomtatvány-gyüjteményének története $=$ Az Egyetemi Könyvtár Évkönyvei 2 (1964) 109-126.). A tár egészéről azóta nem készült újabb, mértékadó szaktudományos publikáció. Legutóbb az Egyetemi Könyvtár 450 éves 
Chronica Hungarorum (Buda, 1473, Andreas Hess; Inc. 10) itt örzött, végig rubrikált példánya -, melyek a kutatás tanúsága szerint megjelenésük óta magyarországi tulajdonban vannak. ${ }^{29}$ Fontos megemlíteni az egykor a budai királyi kápolna (Capella Regis) könyvtárában őrzött Aurelius Augustinus, De Civitate Dei (Roma, 1474, U. Han - S. N. Chardella; Inc. 16) országos unikum példányt is. Egy Velencében 1475-ben nyomtatott Biblia a könyvtárban őrzött legkorábbi nyomtatott Biblia, melyet 1476-ban Budán vásárolt meg egy Ágoston nevủ zágrábi domonkos szerzetes.

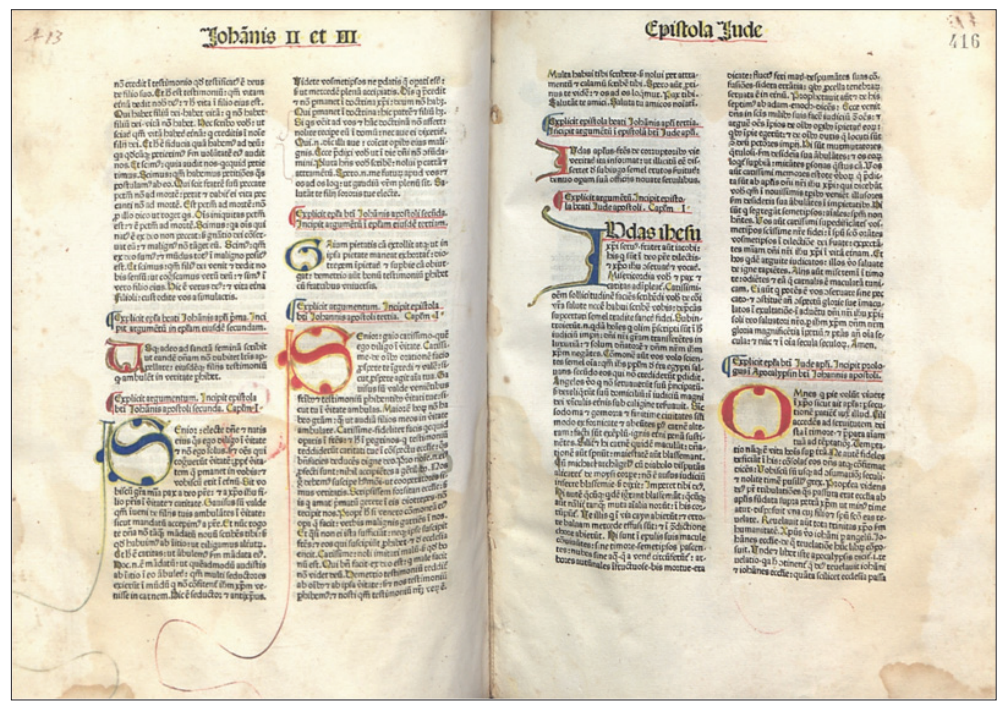

13. kép. A könyvtár legrégebbi nyomtatott Bibliája (Venezia, 1475), 415v-416r, Inc28

Egy másik ősnyomtatvány Bibliát egykor valószínüleg Istvánffy Miklós könyvtárában őriztek, akihez a kötet egy XVIII. századi legenda szerint a Bibliotheca Corviniána állományából került. ${ }^{30}$

múltjába helyezett kétnyelvű művelődéstörténeti bemutatás készült a könyvtár ősnyomtatványairól (Knapp Éva: Ösnyomtatvány-gyüjtemény - Collection of Incunabula. = Knapp Éva - Szögi László, Az Eötvös Loránd Tudományegyetem Egyetemi Könyvtára - University Library of Eötvös Loránd University, Budapest, ELTE Egyetemi Könyvtár, 2012, 94-111). A tár egyes példányairól folyamatosan jelennek meg tudományos szaktanulmányok (az egyik legutóbbi publikáció: Anna Tüskés, A Copy by Israhel van Meckenem of the Luke the Evangelist in Circle Engraving by Master E. S. in the University Library of Budapest $=$ Arbeitskreis Bild Druck Papier Tagungsband Modena 2010, Hrsg. Wolfgang Brückner, Konrad Vanja, Detlef Lorenz, Alberto Milano, Sigrid Nagy, Münster New York - München - Berlin, Waxmann, 2011, 148-153).

${ }^{29}$ A Chronica Hungarorum e példányát a könyvtár múzeumi tárgyakért kapta cserébe 1875ben a mai Országos Széchényi Könyvtár elődjétől, a Nemzeti Múzeum Könyvtárától.

${ }^{30}$ A példákat folytatva, Antoninus Florentinus, Confessionaléjának ([In Hungaria] 1477 [typ. Confessionalis]; Inc. 46) 'A' változatát1633 óta, azaz az egyetem megalapítása elötti időtől folyamatosan örzi a könyvtár. 


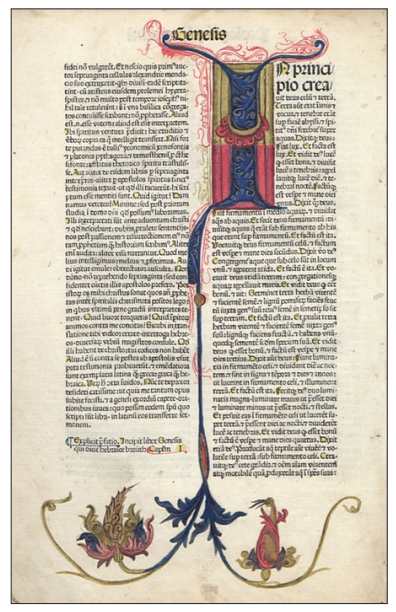

14. kép. Istvánffy Miklós történetíró Bibliája (Venezia, 1476), valószínűleg a Bibliotheca Corvinianából származik. Inc1016 3v

A kötetek egykori tulajdonosi köre nagyon széles, neves humanisták, így például Váradi Péter, idősebb Henckel János (Inc. 179), Mosóczy Zakariás (Inc. 550) éppúgy megtalálhatók közöttük, mint nevezetes magyarországi szerzetesrendi könyvtár (Lövöld = Városlöd karthauzi kolostor, Inc. 139), vagy szerzetes (Hadnagy Bálint budaszentlőrinci pálos szerzetes és hitszónok (1460/70 k. - 1537), Inc. 372³1).

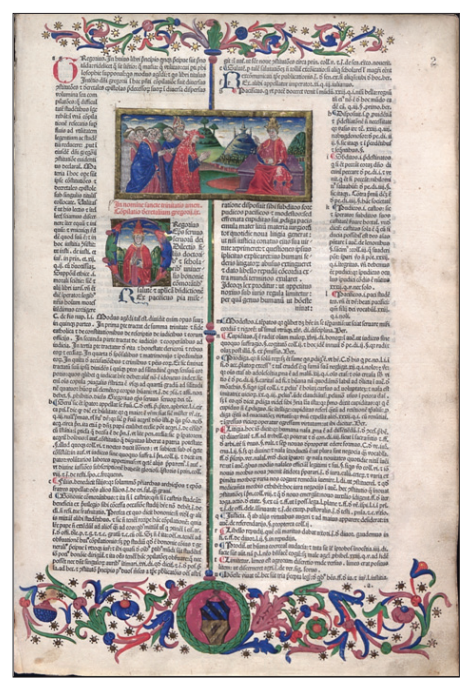

15. kép. A neves humanista Váradi Péter Decretalis-a (Venezia, 1479), 2r Inc65

${ }^{31}$ Az egykor Hadnagy Bálint által használt kötetet később, 1628-ban a lepoglavai pálos kolostor könyvtárában örizték, majd a II. József kori szerzetesrend-feloszlatások következtében szállították be a mai könyvtár jogelőd könyvtárába. 
A tár tervbe vett elektronikus feltárásának eredményeként fény derülhet a történeti könyvtárak és tulajdonosaik, valamint használóik összetett kapcsolatrendszerére, s ez messzemenően gazdagíthatja a világi és egyházi tulajdonosok részletekbe menő kapcsolatának „müködési” formáit, mechanizmusát.

\section{Rezümé}

A dolgozat bemutatja az ELTE Egyetemi Könyvtár ősnyomtatványait, mely az ország harmadik legjelentösebb Ösnyomtatvány-gyüjteménye (Incunabula). A gyüjtemény a könyvtár történetének kezdetétől folyamatosan gyarapodott, törzsgyüjteménnyé alakítása és máig érvényes összerendezése 1879-1882 között zajlott. Az állomány számba vétele megtalálható a magyarországi közgyüjtemények országos ősnyomtatvány-állományát feltáró nyomtatott katalógusban (Catalogus incunabulorum quae in bibliothecis publicis Hungariae asservantur, ediderunt Géza Sajó, Erzsébet Soltész, I-II, Budapestini 1970 Akadémiai Kiadó). A gyüjtemény a könyvtár egyetlen olyan tára, mely hungaricum nyomtatványokat is őriz, azaz 1500. december 31-e előtt Magyarországon, illetve magyar szerzőktől megjelent múveket. A tár a felállítását követő száz évben mintegy száz művel gyarapodott. Ezek nem elsősorban vásárlások útján, hanem a könyvtár raktáraiból, átsorolással kerültek a gyüjteménybe.

\section{The Incunable Collection of the ELTE University Library}

The paper presents the incunable collection of the ELTE University Library, which is the third largest one in the country. The collection has been continuously augmented since the beginnings of the history of the library, its even now existing structure had been formed between 1879 and 1882 . The apiece survey of the collection can be found in the printed catalogue that reviews and describes all the incunable collections that are in the possession of public libraries, archives and museums in Hungary. (Catalogus incunabulorum quae in bibliothecis publicis Hungariae asservantur, ediderunt Géza Sajó, Erzsébet Soltész, I-II, Budapestini 1970 Akadémiai Kiadó). This is the only collection of the library that includes Hungarica prints, namely works that were printed before $31^{\text {st }}$ December 1500, and they originate either from Hungary or they were written by Hungarian author. The century that followed the organization of the collection had augmented it with ca. a hundred works. Not the purchasing was the cause of this accession, but rather finding items in other storages of the library and relocating, recategorizing them.

KNAPP ÉVA

fötanácsos, tudományos ügyek referense ELTE Eötvös Loránd Tudományegyetem Egyetemi Könyvtár 



\section{MUZEÁLIS GYÜJTEMÉNYEK}





\section{Rejtett vizuális értékek \\ 19. századi és modern fotográfiák az ELTE Egyetemi Könyvtárban}

\section{Bevezetés}

Adott terjedelemben természetesen nem lehet kimerítóen leírni és értelmezni az Egyetemi Könyvtár fotóállományát. Ezt már az is megakadályozza, hogy a korpusz csak részlegesen feltárt, felfedezése, összegyüjtése, leírása szinte folyamatosnak mondható a 2000-es évek közepe óta. Szövegemben pusztán felvázolom a képek, fotók fontossá válásának, előtérbe kerülésének némely elméleti aspektusát, és felvillantok pár példát a könyvtár állományából. Úgyszólván narratívatöredékeket alkotok csupán, szilárd, egységes és végleges nagy elbeszélés ${ }^{l}$ nélkül, helyett.

\section{A fotográfia: anomália}

Mindenképpen magyarázatra szorul a szöveg címe. Miért nevezzük, nevezhetjük rejtettnek egy könyvtár vizuális értékeit, azaz a nem könyv/szó-alapú, hanem a képi dokumentumokat, metszeteket, fotókat 2016-ban? A magyarázat, a válasz természetesen már a kérdésben benne rejlik: mert nem könyvek.

Nyugati civilizációnk megőrző, archiváló kultúra, a régiség megőrzendö, archiválandó érték, és a megőrzésnek egészen kifinomult rendszere alakult ki az idők során. A kifinomultság azt jelenti, hogy az archiválásnak egy jól leírható és a megőrzendő tárgyat, dolgot alapul vevő differenciáltsága, pontosabban szólva, szakosodása alakult ki. Nem mindent egy helyen gyüjtünk és archiválunk, hanem, mondjuk úgy, médiumok szerinti elkülönítés és leírás, rendszerezés alakult ki. A szó-és könyvmüvek egy helyen, a képzőmüvészeti alkotások másutt, polgári-, állami-, hadi stb., iratok megint megint másutt kerültek megőrzésre. Minden gyüjtésnek és archiválásnak azonban a rendszer, a rendszerezés a lényege. A rendszerezés pedig csak egy egységes szempontrendszerü leírás alapján lehetséges. Összeírjuk, leírjuk, elkülönítjük a dolgokat, hogy kezelni tudjuk².

A könyvtár elvben verbális kultúránkhoz kötődő és változatos formájú, médiumú dokumentumok gyüjtőhelye. Elvben. Mert minden rendszer, taxonómia és differenciálás elméletben és gyakorlatban is tökéletlen valami, mivel minden rendszerezés valami utólagos tett, gesztus ahhoz képest, ami elötte van, ami megelőzi: maga a mü, amely sok esetben nem illeszkedik egészen pontosan az öt megelőző keretekhez, rendszerekhez, hanem több ponton akár, de áthágja, felülírja

${ }^{1}$ Jean-Francois Lyotard: Széljegyzetek az elbeszélésekhez. = A posztmodern állapot. Jürgen Habermas, Jean-Francois Lyotard, Richard Rorty tanulmányai. Budapest, Századvég. 1993. 146-151 p.

${ }^{2}$ Jacques Derrida: Az archívum kínzó vágya: Freudi impresszió. Wolfgang Ernst: Archívumok morajlása: Rend a rendetlenségből. Budapest, Kijárat. 2008. 
azokat. A rendszerben, archívumban tehát folyamatosan keletkeznek, keletkeztek anomáliák. Jelen esetben egy könyvtár gyarapításában, gyarapodásában minden anomáliának tekinthető, ami eltér a hagyományos szó/könyvmü keretektől.

Ilyen anomália volt sokáig a meglévő könyvtári kereteket, rendszereket, leírási szabályokat kikerülő, nehezen, vagy sehogyan sem osztályozható, értelmezhető fotográfia, és a vizuális alkotások sokfélesége.

A fotográfia általában nem tartozott, nem tartozik egy könyvtár gyüjtő-, és érdeklődési körébe. A fotográfia egyszerüen csak ott van, ott lesz, bekerül egy állományba. Ha az Egyetemi Könyvtárat nézzük, de talán általánosíthatunk is, a könyvtárakba a fotográfiák sok esetben rejtélyesen kerülnek, nincs be-vezetö nyomuk. Rejtőzhetnek egy terjedelmesebb kézirathagyaték bizonyos részeiben, könyvekben illusztrációként, de könyvekben felejtett privát emlékként is. Vannak persze szorosan a könyvekhez kötődő fotóállományok, ezek az analóg fotó, és analóg sokszorosítás korszakában keletkezett fotómásolatok dokumentum-együttesekről, könyvekröl, kéziratokról. Közös tulajdonságuk, hogy gyakran pusztán egy-egy állományrész közelében kaptak helyet, önálló leírás, és akár leltárba vétel, jelzet nélkül.

A fotó valaminek pusztán az illusztrációja, másolata, valami másodlagos, másodrendủ, önállóan jelentéktelen, megnevezésre, leírásra sem méltó dologként rejtözködött, rejtözködhet egy könyvtárban. Nem ott van a helye. De hogy hol lenne az a hely, még most, ma sem tudjuk megmondani minden esetben.

Mert a fotók könyvtárban lévő problematikus státuszának oka nem pusztán az, hogy az emberi szabadság vagy hanyagság okán anomáliaként olyan rendszerbe kerültek, ami nem a sajátjuk, hanem az, hogy nincs igazán sehol sem helyük, bizonyos értelemben a fotográfiák egy nagy hányada mindenhol anomáliaként egzisztál.

\section{A fotográfia létmódjáról}

A fotográfia ugyanis nem egy-, hanem többlényegü entitás. Anomália-, és rendszereken túllépő volta illékony és megfoghatatlan lényegében keresendő. A puszta fotóról ugyanis, kontextus híján semmi sem mondható el. A puszta fotó elsősorban persze sokszorosítható dolog ${ }^{3}$, tehát nem egyedi dokumentum, nem egy van belőle, hanem a lehetőségeket számba véve: virtuálisan végtelen szám. A fotót másodsorban tárgya határozza meg, amit ábrázol. Utána az ábrázolás mikéntje. Ezek után pedig az ábrázolás kontextusa. Mert ugyanazt a médiumot használta, használja a müvészet, a tudomány különböző ágai ${ }^{4}$, az ipar, emellett a privát ember. Egy absztrakt fotó lehet egy csillagászati, vagy sebészeti, vagy anyagtani illusztráció, de lehet egy privátfotó is. A legtöbb esetben, kontextus híján, a fotóhoz kapcsolódó szöveges leírás híján a fotóról nem állapítható meg

${ }^{3}$ Walter Benjamin: A műalkotás a technikai reprodukálhatóság korában. [Kurucz Andrea új fordítását átdolgozta: Mélyi József] = http://aura.c3.hu/walter benjamin.html

${ }^{4}$ Horst Bredekamp - Franziska Brons: A fotográfia mint tudományos médium. $=$ A kép a médiamüvészet korában. Budapest, L'Harmattan. 2006. 147-176. p. 
sem a készítése célja, sem a kora, sem az alkotója, és természetesen a példányszáma sem. A fotográfia lényegét illető alapprobléma ma is, mitől nevezzük müvészinek a fotót, mitől tudományosnak, mitől puszta privát dokumentum?

A fotó lényege erős kontextusfüggősége, így létmódjának illékonysága, cseppfolyós volta, ebből következően a rendszerezésnek, leírásnak való erős ellenszegülése, azaz a rejtőzködő létformája.

Paradox módon, ennek a rejtőzködő létformának szöges ellentéte a fotográfia elterjedtsége, tömeges volta. Annak ellenére, hogy fiatal médium, hihetetlen karriert futott be, jelen pillanatra pedig úgyszólván elöntötte világunkat.

\section{Képi fordulat}

Kultúránkban ugyanis jó ideje egyfajta változás, hangsúly-áthelyeződés tanúi vagyunk. Szó-alapú civilizációnk ugyanis némiképp kép-alapúvá vált, jóval nagyobb hangsúly helyeződik a képekre, szinte kommunikációnk alapja a kép5. Számtalan bizonyíték szól amellett, hogy adott esetben egy gyerek hamarabb tanul meg képekkel kommunikálni, képeket kezelni, mint beszélni ${ }^{6}$.

Meggyőződésem, hogy a 20. század második felében végbement változás, vagy képi forradalom, vagy képi fordulat, ahogy W.J.T. Mitchell programadó 1992-es írásában meghatározza: „A képi fordulat, a képek által totálisan uralt kultúra fantáziája mára reális technikai lehetőséggé vált az egész világon." képi fordulat előkészítése a 19. században kezdődött, egészen pontosan a világ első fennmaradt fényképével, Niépce „Kilátás a dolgozószobából” c. 1927-es müvével.

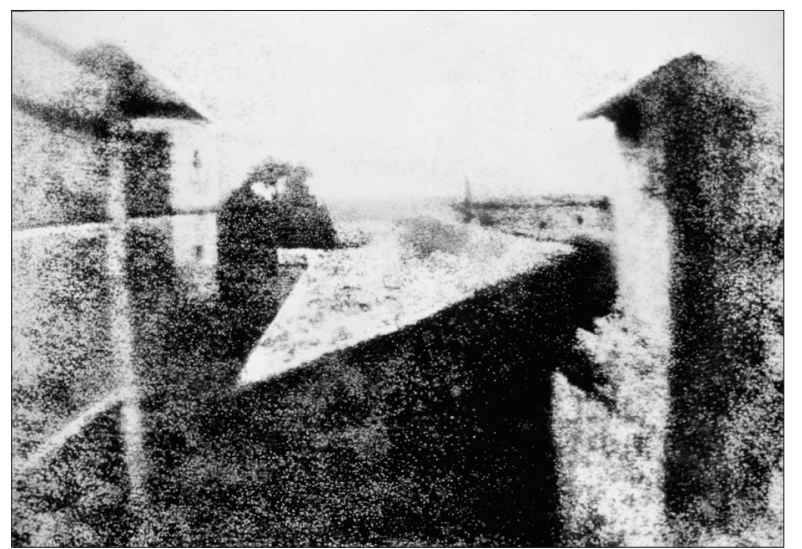

1. kép. Nicéphore Niépce: Point de vue du Gras, 1826/1827

\footnotetext{
${ }^{5}$ Horst Bredekamp: Fordulópontok. Az iconic turn ismertetőjegyei és igényei. $=$ A kép a médiaművészet korában. Budapest, L'Harmattan. 2006. 11-25. p

${ }^{6}$ Vilém Flusser: Az írás: Van-e jövője az írásnak? [Budapest], Balassi - BAE Tartóshullám Intermedia. 1997.

${ }^{7}$ William John Thomas Mitchell: A képi fordulat. = A képek politikája: W. J. T. Mitchell válogatott írásai: tanulmányok. Szeged, JATE Press. 2008. 131-155. p.
} 
Annak dacára azonban, hogy a világot elborító képözön, a képi elbeszélések, jelentések dominanciája a fotográfiával kezdődött, és jelen pillanatban is a fotó a globális képkultúra vezető médiuma, feldolgozottsága, értése, leírása meszsze elmarad a könyvekétől. Még mindig nincs meg hozzá a megfelelően pontos nyelvünk, eszközeink, de ez nem feltétlenül a könyvtárosok hiányossága, hanem oka a képek, fotográfiák létmódjában keresendő.

Azt mondhatjuk, hogy a fotók leírása, értése, rendszerezése nemcsak egy könyvtárban szenvedett hátrányt vagy maradt el, hanem szinte minden területen. Egész egyszerüen azért, mert logosz-alapú civilizációnk még mindig a képek után kullog, tehát még mindig nincsenek meg az elég finom, szofisztikált eszközeink a fotók rendszerezésére, mert még mindig, és jó ideje egy képi forradalomban élünk, és inkább használjuk a fotókat, mintsem, hogy elgondolkodnánk róluk.

\section{Roger Fenton fotói}

A fotográfiák előtérbe kerülésének az Egyetemi Könyvtárban különleges és szép narratívája van. A könyvtár metszetgyüjteménye számítógépes feldolgozása során, amelyet egy mủvészettörténész, Papp Júlia végzett A Magyar Tudományos Akadémia támogatásával 2003 és 2006 között, került elő 2006 tájékán egy nagyalakú mappából Roger Fenton (1819-1869) több, eredeti, jórészt szignált fotója.

A fotók felbukkanása, leírásuk, szakértésük, kiállításuk egyfajta katalizátora volt a könyvtár lappangó, de sok esetben különlegesen értékes fotóállománya napfényre-hozásának, leírásának, prezentálásának.

Roger Fenton a 19. századi fotográfia egyik legnagyobb alakja volt, aki bár mindössze ötven évet élt, és 11 éven keresztül foglalkozott fotográfiával, szinte a fotózás minden ágában és müfajában jelentős súlyú, világhírü életmüvet alkotott ${ }^{8}$. Elég, ha csak megemlítjük, hogy egyik alapítója a Royal Photographic Society-nak, egy időben ő volt a brit királyi család fényképésze, később a British Museum mütárgyfényképészeként alkotott maradandót, majd 1855-ben hadifényképészként alkotta meg talán leghíresebb felvételeit a krími háborúban, majd fotomechanikai képnyomtatási kísérletekbe vágott bele, később az épületfényképezéssel foglalkozott, majd a korban divatos orientalizáló képek és sztereóképek készítésével.

${ }^{8}$ Roger Fenton: All the mighty world: The photographs of Roger Fenton, 1852-1860. New Haven - London - Yale University. Press. 2004. 


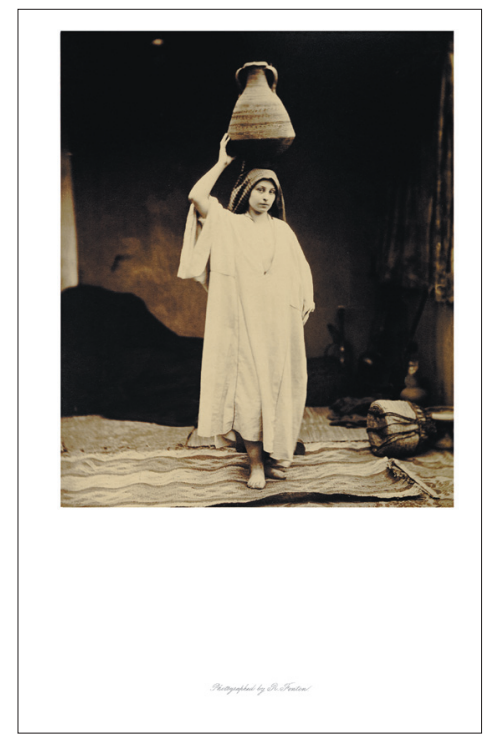

2. kép. Roger Fenton: Cím nélkül, 1858

Fenton életmüvének darabjai pénzbeli értékükre nézve is igen értékesek, aukciókon világszerte komoly összegekért kelnek el, így az Egyetemi Könyvtárban megtalált majdhogynem hibátlan, restaurálásra nem szoruló, jórészt szignált, 1856-1858-ban keletkezett 12 felvétel anyagi tekintetben is különlegesen értékes lehet, hiszen, ahogy Papp Júlia a 2008-2009-ben megvalósult „El nem veszett, de megtalált képek” c. Roger Fenton fotókiállítás katalógusában írt tanulmányában ${ }^{9}$ elmondja, öt képnek nem találta külföldi közgyüjteményben nyomát, tehát elképzelhető, hogy a fotók egyedi darabok, vagy ritka, csekély számú másolat lehet belölük a világon.

A fotók napvilágra bukkanása és feldolgozásuk körülményei természetesen példaértéküek a tekintetben, hogy a fotókat nem könyvtáros, hanem egy külsős, azaz egy mủvészettörténész dolgozta fel, de ő sem pusztán saját tudására, hanem további szakemberekére hagyatkozva, hiszen a fotók megtalálása után azonnal szakértőket vont be a könyvtár, a hazai fotótörténész szakma két legnagyobb tekintélyét, Kincses Károlyt és Flesch Bálintot a képek azonosítása, értékük hozzávetőleges megállapítása céljából. Így nyert megállapítást az is, hogy majdnem $100 \%$.os valószínüséggel nincs több Roger Fenton fotó Magyarországon. A szakértők adtak továbbá tanácsot a fotók professzionális, a könyvekétől természetesen eltérő tárolására, védelmére vonatkozóan is, ami kiterjedt a később megvalósuló kiállításuk megfelelő körülményeinek biztosítására is.

${ }^{9}$ Papp Júlia: Roger Fenton (1819-1869) tizenkét képe a budapesti Egyetemi Könyvtárban. = Roger Fenton fényképei. Budapest, ELTE Egyetemi Könyvtár. 2009. 15. p. 
Ez az eset azonban szerencsésnek és talán kivételesnek mondható, hiszen, bár továbbra sem tudjuk, hogyan kerültek a könyvtárba a képek, és miért nem vették őket állományba, de maguk a fotók jól kontextualizáltak voltak, azaz megfelelő és pontos szöveg kísérte őket, hiszen mindegyik kép paszpartuban volt, melyen szerepelt a fotós neve és a kép helyszíne, címe is, amellett, hogy több kép magán viseli az alkotója szignóját, továbbá sorszámokat is. További szerencse, hogy a fotós egy híres, ismert és jól dokumentált alkotó, így számtalan adatnak utána tudott nyomozni a kutató.

\section{„Keleti album”}

A fenti cím pusztán egy munkacím egy nagyméretü, 84 eredeti, keleti témájú fotográfiát tartalmazó album számára, amelyet 2016-ban fedeztünk fel a könyvtár raktárában. Az eset érdekessége, hogy míg a Fenton-fotók állományba vétel nélkül, egy mappában hevertek a könyvtár kézirattárában, a „Keleti album” bizonyos mértékig feldolgozott állapotban és jelzettel ellátva, a könyvtár könyvállományába lett besorolva. A probléma csak az, hogy az album nem egy sokszorosított, nyomtatott munka, hanem egyedi darab, egyedi példány, valószínúleg egy gazdag fóúr, gyüjtő készíttette el a maga számára, amikor összegyüjtötte, összevásárolta az albumban szereplő fotográfiákat a kor neves fotográfusaitól. Az album különleges értékét ugyanis az adja, hogy majdnem mindegyik képről megállapítható, ki az alkotója, így körülbelüli készítésük éve is. Az album fotói Egyiptomban, Palesztinában, Kis-Ázsiában, Törökországban és Görögországban készültek az 1860-1890-es években. A képeket nagy része szignált, és a 19. század neves fotográfusai készítették: Antoni Beato, Francis Bedford, Félix Bonfils, Peter Bergheim és Frank Mason Good.

Az album és fotói, akárcsak a Fenton-képek igen jó állapotban maradtak ránk, valószínüleg a bekerülésük után nem használta, kérte őket semmilyen olvasó, köszönhetően rejtözködésüknek, hiszen gyakorlatilag megtalálhatatlanok voltak a katalógusunkban, amelyben „Album” néven szerepeltek. Természetesen raktári helyük a kéziratok, azaz az egyedi, különleges értéket képviselő, és megfelelő őrzést igénylő dokumentumok között van. Az album természetesen további fotótörténeti kutatásra és azonosításra vár, azon túl, hogy itt sem ismerjük a könyvtár állományába kerülés körülményeit, azaz az eredetet.

\section{„Isonzói album"}

A következö, történeti szempontból izgalmas tétel, egy ugyancsak nemrég, a nagyraktári állományban talált, de a kézirattárba tartozó 267 eredeti, és néha izgalmas panorámafotókat tartalmazó fotóalbum, valószínüleg 1915-ből, az osztrák-magyar csapatok isonzói hétköznapjairól. Az album leírásra került és a kézirattárba irányítottuk, de a fentieken kívül jelen pillanatban nem tudunk a képekről semmit. Bi- 
zonyos képeken szerepel a helyszín, de más semmi. Nyilvánvalóan jelen esetben nem beszélhetünk különleges múvészi értékről, neves fotográfusról, viszont egy történész vagy hadtörténész számára izgalmas terep lehet a kutatásra. A képek állapota, dacára annak, hogy korban fiatalabbak, mint a 19. századi fotók, készülésük körülményei és a fotótechnika fejlődése következtében, bizonyos értelemben a könnyebben használható, ám kevésbé időtálló minőségủ anyagok miatt, rosszabb, mint pl a Fenton-fotóké. Maga az album anyaga, minősége sem olyan időtálló, hiszen más célra készült, állították össze.

\section{Töredékek}

A következőkben csak megemlítek pár kisebb töredéket a gyüjteményből.

Ugyancsak pár éves felfedezés a könyvtárépületről kb. az 1920-as években készült $9 \times 12 \mathrm{~cm}$-es üvegnegatív, amelynek nem ismerjük az alkotóját.

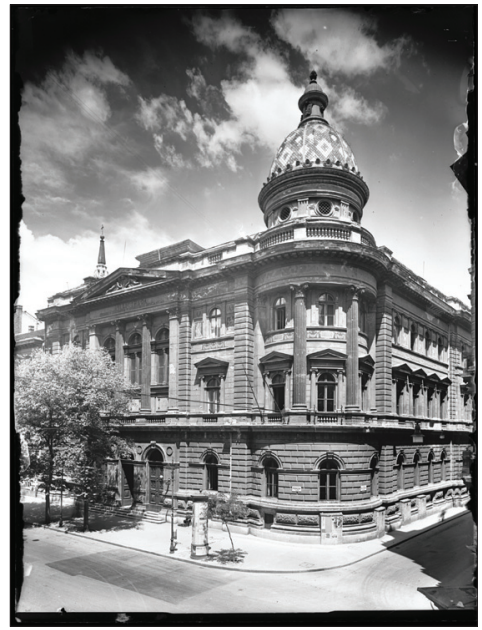

3. kép. Ismeretlen alkotó: Az Egyetemi Könyvtár épülete, 1920-as évek

A nagyraktári könyvállományban találtunk nemrég egy nagyalakú, kiváló állapotban megőrződött 1867-es fotót a philadelphiai Public Ledger Building-ről, amely 1867-1920 között a Public Ledger c. napilap fóépülete volt. Az épületet ifj. John McArthur tervezte. A fotót Fredrick Gutenkunst készítette, mégpedig egy akkor éppen frissen szabadalmaztatott fotográfiai objektívvel, Joseph Zentmayer Zentmayer-objektívjével. Ennél a képnél is szerencsénk van, mivel a kép kiválóan dokumentált, minden képadat a paszpartun szerepel.

A kézirattári mappák egyikében találtuk Erdélyi Mórnak az 1920-as évek környékén, az Egyetemi Könyvtárról készült négy, relatíve jó állapotban megőrződött felvételét. A képek mindegyike szignált, készítésük éve azonban csak kikövetkeztethetö, de nem azonosítható teljes pontossággal. 
Nevezetes tétele a kézirattárunknak az eredeti fotókkal illusztrált „People of India" (1868-1872) c. 6 kötetes, J. Forbes Watson, John William Kaye szerkesztette album, amely összesen 339 képet tartalmaz, és a teljesség igényével és objektivitásával kívánja leírni India embereit. A mű szerencsére kivételesen jól dokumentált, Argyll herceg, India kormányzásáért felelős államtitkár adományozta, állítólag Vámbéry Ármin közbenjárására a könyvtárnak.

\section{Rezümé}

A szöveg elméleti része kultúrtörténeti-, és fotóelméleti kontextusban járja körül a logocentrikus-, és a képkultúra összefüggéseit, annak magyarázatára, miért rejtettek, kevéssé feldolgozottak a könyvtárak vizuális dokumentumai, fotográfiai anyaga. Vázolásra kerülnek a fotók leírásának, értelmezésének nehézségei, továbbá az, hogy nemcsak a könyvtárak maradnak el a fotók leírásában, értelmezésében, hanem ez kultúránk strukturális hibája, állapota. Az előadás további részében az Egyetemi Könyvtár néhány fotólelete kerül bemutatásra, többek között a Fenton-fotográfák, egy orientalizáló album, egy első világháborús album, továbbá a könyvtárról készült 19. századi és 20. század eleji fotográfák.

\section{Hidden Visual Treasures - Photographs from the 19th and 20th Centuries in the ELTE University Library}

The theoretical part of the text analyses the relation between the logocentric culture and the image culture in the context of cultural history and the theory of photography in order to explain why the visual documents, photographic materials of the libraries are hidden mostly uncatalogued. There are presented the difficulties of the descriptions, interpretations of photos, and the fact that not only the libraries are behindhand in describing photos, but this delay is possibly the consequence of the structural default, condition of our culture. In the paper a few photos of the University Library are presented, among others the photos of Roger Fenton, an Orientalizing album, an album from the World War I. and a few photos of the library from the 19th and early 20th century.

CSÉKA GYÖRGY

osztályvezető, Közönségszolgálati Osztály ELTE Eötvös Loránd Tudományegyetem Egyetemi Könyvtár 
Hagyományok és kihívások V. Múlt és jövő. Országos Könyvtárszakmai Nap, 2016.

Szerk. Szabó Panna, Székelyné Török Tünde.

Budapest, ELTE Egyetemi Könyvtár és Levéltár. 2017. 99-109.

\section{Pauler Tivadar jogi szakkönyvtárának 1872-es katalógusa ${ }^{1}$}

Pauler Tivadar egyetemi tanár, vallás- és közoktatásügyi, majd kétszer igazságügy miniszter és a Magyar Tudományos Akadémia tagja volt. A 19. század második felének meghatározó jogásza, élete és munkássága viszonylag jól feltárt, ${ }^{2}$ noha az Országos Széchényi Könyvtár Kézirattárában őrzött, mintegy 800 fólió terjedelmü, 1845-től haláláig vezetett naplója máig kiadatlan. ${ }^{3}$ Lelkes és elkötelezett könyvgyüjtö lévén könyvtárában ritka és értékes müvek voltak, amelynek katalógusa fennmaradt az ELTE Egyetemi Könyvtár Kézirattárában őrzött hagyatékának dokumentumai és személyes tárgyai között. A több mint ezerhatszáz tételes katalógus 1872-ben készült, amikor Pauler ötvenhat éves volt. A gyüjtemény föleg jogi szakirodalomból áll, de mutatja tulajdonosa érdeklődését a történelem, az irodalom, a vallás és az utazás iránt is. Nagyon fontos figyelembe venni, hogy ez egy müködő, funkcionális könyvtár volt, napi munkájához használta ezeket Pauler.

A Pauler család hagyatékának katalógusát 2004-ben készítettem el az ELTE Egyetemi Könyvtárban, amely azóta online hozzáférhető a könyvtár honlapján pdf formátumban. ${ }^{4}$ Akkor vettem kézbe számos családi ereklyét, például Pauler Tivadar tízéves korában készített gimnáziumi írásgyakorlatát (1. kép), 1861-es fényképét (2. kép), névjegyét, gyászjelentését, felesége, Deréky Sarolta hajtincsét. Akkor írtam le az 1872-es könyvtárkatalógusát, a címleírások azonosításával

${ }^{1}$ Az előadás angol változata elhangzott a „Knižnica ako fenomén kultúry a vzdelanosti. / Libraries as Phenomenon of Culture and Erudition" című konferencián. Martin, Literárne múzeum SNK, 2016. május 11-13.

${ }^{2}$ Ld. pl.: Szabadfalvi József: Pauler Tivadar, az észjogtudomány utolsó nagy alakja. $=$ Zempléni Múzsa, 14. évf. 2014. 2. sz. 12-18. p.; Estók József: A magyar börtönügy arcképcsarnoka: Pauler Tivadar (1816-1886). = Börtönügyi Szemle, 28. évf. 2009. 4. sz. 69-74. p.; P. Miklós Tamás: Adalékok Pauler Tivadar (1816-1886) pályafutásához. = Comitatus, 8. évf. 1998. 3. sz. 62-70 p.; Felkai László: Pauler Tivadar, a közoktatásügyi miniszter. = Pedagógiai Szemle, 37. évf. 1987. 1. sz. $50-58$ p.

${ }^{3}$ Quart. Hung. 2611/1. 355 f., 2611/2. 429 f. A Zágrábban 1844. december 31-én éjjel 3/4 12-kor kelt első bejegyzés tanúsága szerint: „Jelen soroknak czélja nem egy rendes naplónak vezetése, hanem egyedül azon események feljegyzése, mellyeket vagy családi vagy pedig egyéb tekinteteknél fogva a 'feledékenység' örvényéből megmentendőknek találnék. - Sok enyészik az emberi emlékező tehetségéből, mit megtartani tanácsos szükséges volna, ezt tehát megakadályoztatni kivánságom szándékom. - Legyenek évek mulva jelen lapok segédszerül emlékezetemnek; - foglaljanak magukba sok örvendetest, sok jót; kevés szomorítót.” „Egyedül saját használatomra” Pauler naponta átlag 3-5 sort írt naplójába: feljegyezte, milyen az időjárás, mit dolgozott, kikkel találkozott. 1933-ban került a Magyar Nemzeti Múzeum Könyvtár Kézirattárába.

${ }^{4}$ NKA, pályázati azonosító 2120/0229. http://www.konyvtar.elte.hu/regi/kincseink/kezirat/ pauler.htm [2015.06.24.] 
azonban nem foglalkoztam. Amikor elkezdtem azonosítani az egyes tételeket, jó néhány elírást találtam a tíz évvel ezelőtt készített listámban.

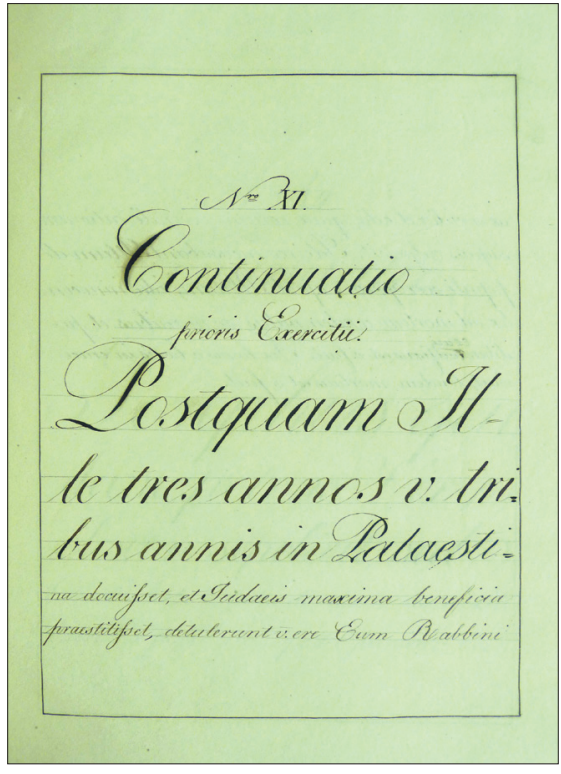

1. kép. Pauler Tivadar tízéves korában készített gimnáziumi írásgyakorlata

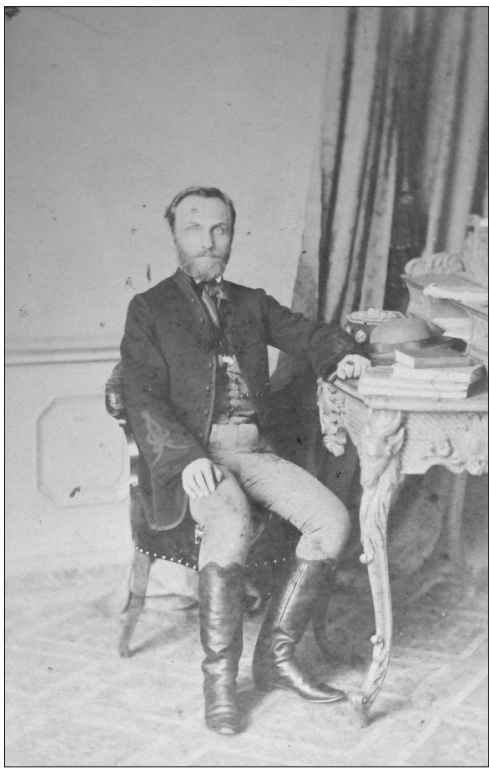

2. kép. Pauler Tivadar 1861-es fényképe

A kéziratos katalógus 1620 tételt tartalmaz. Minden tétel külön kartonon van, és a kartonok a szerző vagy a mücím betürendjében hat mappába vannak bekötve (3. kép). A katalógust egy kéz írta, a könyvtár 1872-es állapotát tükrözi, nincsenek benne későbbi mủvek. A katalóguscédulákon található tételek két részből állnak: 1. az elhelyezést mutató szám- és betűtagból álló kombináció, 2. maga a bibliográfiai leírás (4. kép). Munkám során kíváncsi voltam, vajon milyen lehetett a számés betütagból álló kombinációból adódó csoportosítás. Azt feltételeztem, hogy kirajzolódik valamiféle tematikus rendszer. Úgy gondoltam, hogy ez a csoportosítás betekintést enged a könyvtár elrendezésébe és tulajdonosa gondolkodásmódjába. Hipotézisem azonban nem nyert megerősítést, mert egyes egységekben nagyon különbözö tematikájú müvek kerültek, például az I. A. kategóriában van Berzsenyi Dániel összes müvei, Török János Magyarország Primása címü könyve, a Törvénykezési Lapok 1857-es kötete és Zalka János Szentek Élete címü munkája. Más egységek viszont homogéneknek tünnek, például az I. B. kategóriában kizárólag jogi művek szerepelnek. A II. C. kategóriában a természetjog dominál. Az I. D. kategóriába két folyóirat tartozik, az Uj Magyar Muzeum 1850-1859 között megjelent 18 kötete és a Magyar Akadémiai Értesitő 1847-1862 közötti 16 kötete. A legtöbb szabadkőműves munka az I. H. kategóriában van. 


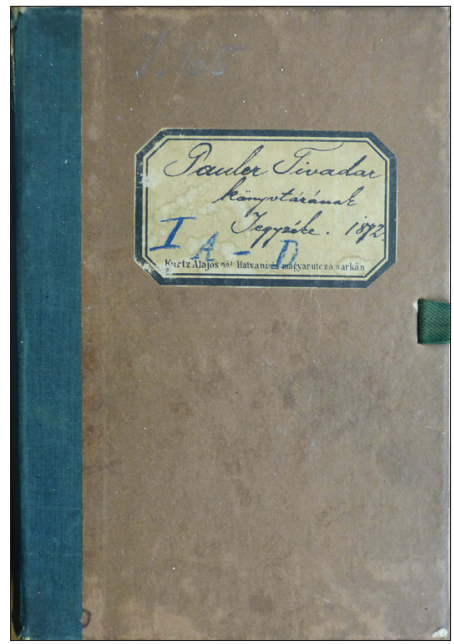

3. kép. A kéziratos katalógus első mappája

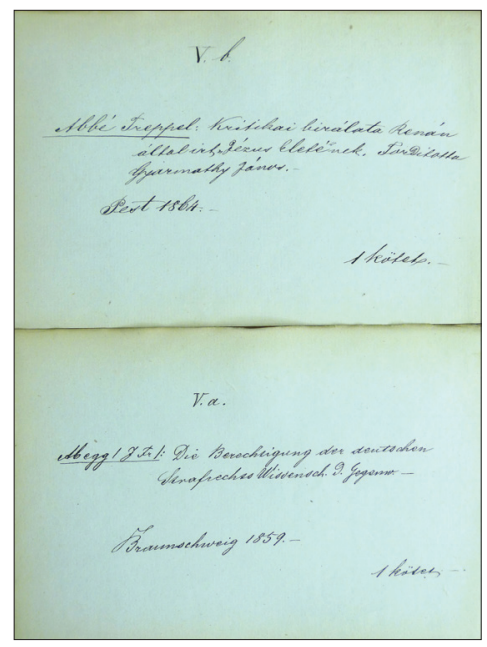

4. kép. Két katalóguscédula

Nemcsak a katalógus, hanem a könyvállomány egy része is megvan az ELTE Egyetemi Könyvtárban és más magyarországi egyetemi könyvtárakban. Az ELTE Egyetemi Könyvtárban található kötetek azonosítása nem egyszerü: egyesekben Pauler saját kezü, fekete tintával írt possessor bejegyzését találtam (5. kép), másokban pedig a feltehetően a könyvtárba kerüléskor beírt ceruzás „Pauler” bejegyzés olvasható (6. kép). Némely kötet korábbi tulajdonosa Zelenay János József, a nagyszombati egyetem jogi karának tanára (164., 1420., 7. kép). Más könyvek korábban a nagyszombati jezsuita kollégium tulajdonát képezték (237., 8. kép). Egy könyv korábbi tulajdonosa Caspar Gilbert Mellerstad stettfeldi plébános volt (141., 9. kép).

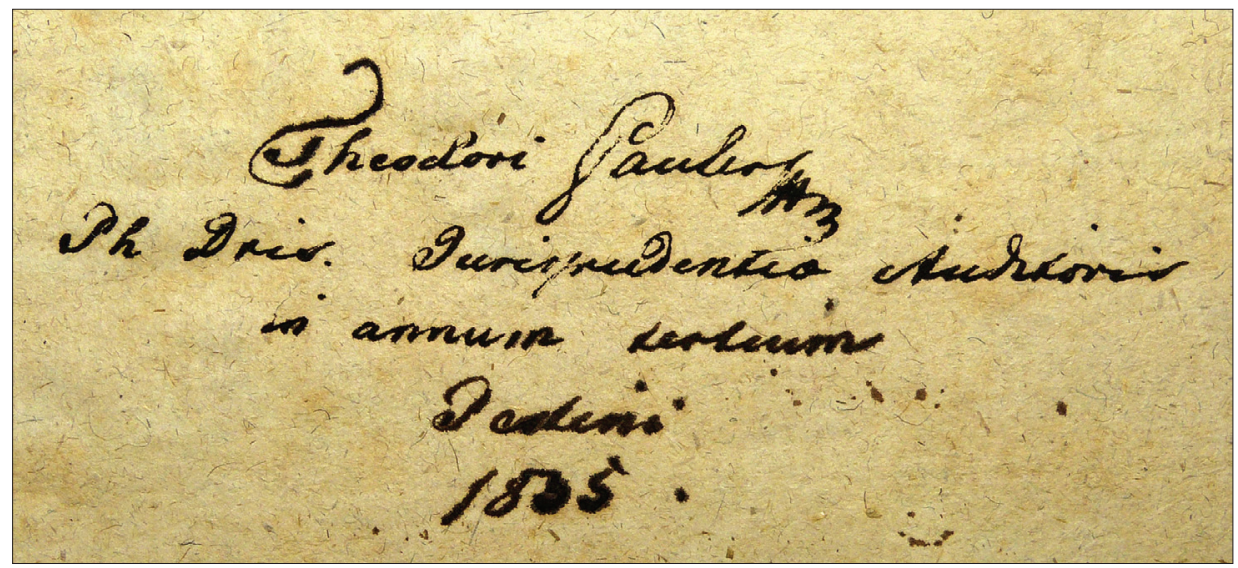

5. kép. Pauler saját kezü, fekete tintával írt possessor bejegyzése 


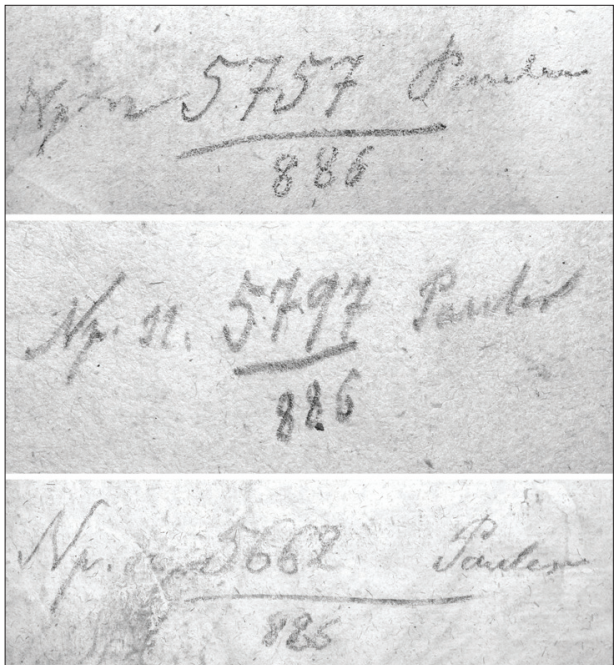

6. kép. Ceruzás „Pauler” bejegyzés

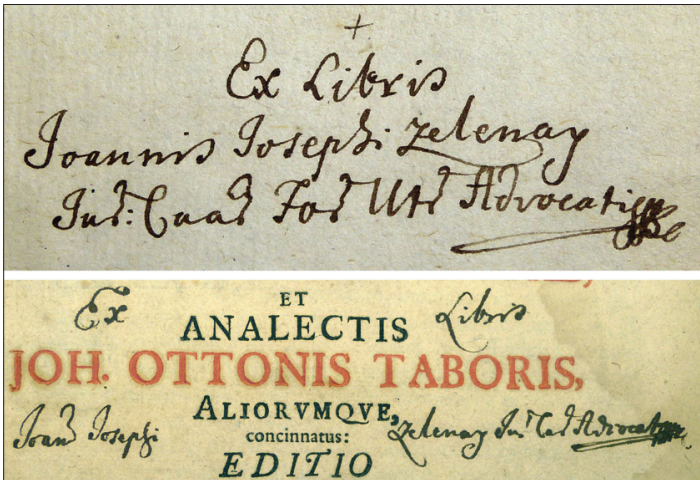

7. kép. Zelenay János József, korábbi tulajdonos gyüjteményéből

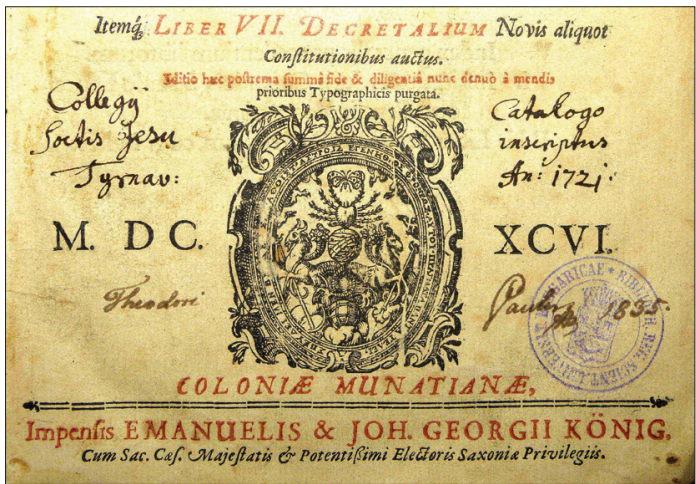

8. kép. A nagyszombati jezsuita kollégium egykori gyüjteményéből 


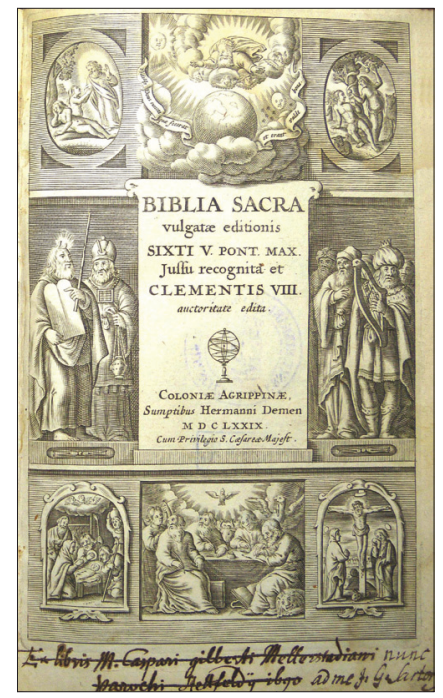

9. kép. Caspar Gilbert Mellerstad stettfeldi plébános, korábbi tuljadonos gyüjteményéböl

További köteteket a „Pauler Tivadaré” bélyegzőcímke azonosít a pécsi, a szegedi és a debreceni egyetemi könyvtárakban. Négy mü például a Pécsi Tudományegyetem Egyetemi Könyvtár és Tudásközpontban található, ahova a „Tudomány- és Müegyetemi Olvasókör'-ből került: 1. Ludwig Ross Wanderung in Griechenland (1169.), 2. Schwartner Márton Statistik des Königreichs Ungern (1276.), 3. Johann Springer Statistik des österreichischen Kaiserstaates (1308.), 4. Julius Franz Schneller Staaten-Geschichte (1249.) címü müve. Egy háromkötetes kiadvány, Szibenliszt Mihály Institutiones juris privati Romani-ja (1376.) pedig a Szegedi Tudományegyetem Könyvtárában van. Az 1872-es katalógusban nem szereplö, ezután megjelent vagy beszerzett müvek is találhatók Pauler Tivadar possessor bejegyzésével magyarországi egyetemi könyvtárakban. Ilyen például Plósz Sándor A keresetjogról címü 1876-ban megjelent munkájának Pauler Tivadar pecsétjével és margináliáival ellátott példánya a Debreceni Egyetemi Könyvtárban. Így ezek a müvek ma is tanulmányozhatók, például a könyvészeti kutatások számára, elsősorban a possessor bejegyzések és margináliák szempontjából. Az állomány vizsgálatára eddig nem került sor, munkám során igyekeztem azonosítani és kézbe venni minél több könyvet.

A lista alapján elmondható, hogy Pauler elsőrangú jogi szakkönyvtárat állított össze, amely korának fontos szakmunkáit is tartalmazta. A könyveknek körülbelül kétharmada latin és német nyelvü, a többi magyar és francia. A müvek időbeli eloszlása a következő: 17 könyv származik a 17. századból, ezek jogi és irodalmi müvek. A legkorábbi könyv a francia jogász és filozófus Jean Bodin 1576-ban írt De republica című müvének 1609-es frankfurti kiadása (164.), ezt 
követi Justinianus Institutiojának egy 1622-es kötheni (53.) és egy 1677-es salzburgi kiadása (616.). Van köztük egy Kölnben 1679-ben kiadott Biblia (141.), továbbá antik (Valerius Maximus (1498.) és Ovidius (1015.)), reneszánsz (pl. Joannes Leo Africanus (17.), Justus Lipsius (618.) és Machiavelli (835.)) és barokk írók (pl. Johann Ferdinand Behamb (112.) és Milton (928.)) müvei. A többi könyv körülbelül fele-fele arányban származik a 18. és a 19. századból.

Mint általában a 18-19. századi könyvtárakban, ${ }^{5}$ Paulerében is megtalálható a görög és a latin klasszikusok egy része, különösen az ekkor még tankönyvként használt Marcus Tullius Cicero szerepel sok, pontosan négy mủvével (217-220.), Horatius három (589-591.), Ovidius két (1014-1015.), Sokrates két (1293-1294.), Homeros (588.), Aristoteles (64.), Julius Caesar (203.), Sallustius Crispus (1201.), Seneca (1282.) és Martialis (885.) egy-egy könyvvel van jelen többnyire latin eredetiben, esetleg német vagy magyar fordításban. A Biblia négy kiadása szerepel a könyvtárban: 1. a legkorábbi a már említett 1679-es kölni kiadás (141., 9. kép), 2. a Dietenberger-Biblia utolsó, 1776-os augsburgi kiadása (301.), 3. a Káldi György-féle magyar fordítás Tárkányi B. József átdolgozásával az 1865-ös egri kiadásban (1368.), 4. az evangélikus tanár Kámory Sámuel fordításának második, 1870-es pesti kiadása (669.). Ezen kívül a magyar állam müködésével kapcsolatos, többnyire jogi és országgyülési dokumentumok, statisztikák, vallási és egyháztörténeti tárgyú kötetek, a magyar történelem középkori és újkori szerzői (Anonymus, Pray György).

Ugyanakkor számtalan egyedi vonás is megfigyelhető. Például erőteljes szabadkőmüves érdeklődésre vallanak egyes tételek (48., 138., 404., 411., 429., 722.,

${ }^{5}$ Vö. pl. Buda Attila: A Károlyiak fóti könyvtára. = Szabolcs-Szatmár-Beregi levéltári évkönyv, XVII. Szerk.: Galambos Sándor, Kujbusné Mecsei Éva. Nyíregyháza, Szabolcs-Szatmár-Bereg Megyei Önkormányzat Levéltára, 2006. 535-548. p.; Csorba György: Kmety György könyvhagyatéka a Magyar Tudományos Akadémia Könyvtárában. = Hadtörténelmi Közlemények, 126. évf. 2013. 3. sz. 839-853. p.; Gángó Gábor: Eötvös József könyvtára. Budapest, Argumentum, 1995.; Granasztói Olga: Olvasótól - olvasóig. Észrevételek a magyar olvasástörténeti kutatások aktuális kérdéseihez. $=$ Korall, 12. évf. 2011. 43. sz. 5-24. p.; Gyáni Gábor: Az olvasó táblabíró. Középosztályi müveltség a 19. század végén. = Történelmi Szemle, 41. évf. 1999. 3-4. sz. 387-403. p.; Hudi József: Könyv és társadalom. Könyvkultúra és müvelődés a XVIII-XX. századi Veszprém megyében. Budapest, Gondolat. 2009.; Halmos Károly-Sebők Richárd: Hild József könyvtára. Rövid ismertetés és konkordancia. = Tanulmányok Budapest Múltjából, 38. Budapest, BTM. 2013. 57-114. p.; Kocsis Éva: Mátyás Flórián, Pécs első akadémikusának könyvtára. $=$ Rangos famíliák -jeles személyek a 18-20. századi Dél-Dunántúlon. Baranyai Történelmi Közlemények, 6. Szerk. Kult László, Ódor Imre. Pécs, Magyar Nemzeti Levéltár Baranya Megyei Levéltára, 2014. 215-244. p.; Marótzy Katalin: Wéber Antal könyvtára. Adalékok a XIX. századi építészeti szakirodalom kutatásához. = Építés-Építészettudomány, 34. évf, 2006. 1-2. sz. 87-112. p.; Perényi Roland: Mit olvas a pesti polgár? Kísérlet a Janny család könyvtárának rekonstrukciójára. = Tanulmányok Budapest Múltjából, 33. Budapest, BTM. 2007. 59-70. p.; Szabó G. Zoltán: Kölcsey Ferenc könyvtára és olvasmányai. Budapest, Országos Széchényi Könyvtár, Gondolat Kiadó. 2009.; Vörös Károly: Egy győri nemes könyvtára a forradalom előtt. Adalék reformkori általános müveltségünk történetéhez. = Magyar Könyvszemle, 71. évf. 1955. 1-2. sz. 72-87. p. 
813., 1114., 1514-1515.). Ezek között találjuk például 1. a közgazdász, ügyvéd majd nyomdatulajdonos Jean-Pierre-Louis Beyerlé Versuch über die Freimaurerei címü müvét (1514.); 2. a fiatalon a „felvilágosodás” szolgálatába állt, majd mélyen vallásossá vált protestáns teológus, Paul Joachim Siegmund Vogel Briefen die Freimaurerei betreffend című kiadványát (411.); 3. a skót James Anderson által írt kétkötetes Szabadkömüves alkotmányt (48., 722.); 4. a több magyarországi páholy alapítójának, Ludwig Lewis-nak a Geschichte der Freimaurerei in Österreich címü müvét (813.); 5. a német Karl August Ragotzky Unterhaltungen für denkender Freymaurer címü kötetét (1114.); és 6. a Betbuch für Freymaurert (138.).

A katalógus tételei között számos, kifejezetten katolikus mủ található. A Biblia négy kiadásán kívül öt, szentek életét bemutató könyv, legendárium szerepel: 1. a Zalka János püspök és Zsihovics Ferenc kanonok által írt Szentek élete több kötete az 1850-es és 1860-as évekből (1602., 1616-1617.); 2. a francia publicista, történész, Charles Forbes Montalembert gróf 1836-ban írt első történelmi könyve a Magyar Szent Erzsébet történetéről, ami magyar fordításban 1862-ben Egerben jelent meg (944.); 3. az irodalomtörténész Toldy Ferenc két nyelvemlékkiadását birtokolta Pauler 1858-1859-ből: a Magyar szentek legendái a Carthausi Névtelentöl és A Debreczeni legendáskönyv a Krisztina-legendával együtt (1445., 1453.). Az I. Rákóczi Ferencről elnevezett Officium Rákóczianum című imádságoskönyvnek egy késői, 1825-ben Budán nyomott kiadásából két példány is megvolt a könyvtárban (992.). ${ }^{6}$ Egyetemes egyháztörténetet tárgyaló munkák is megtalálhatók a gyüjteményében, pl. a tridenti zsinatról (1196.) és két mủ a jezsuita rendtörténetről (440., 1587.).

A könyvtár fö tematikája a jog. Hét mü foglalkozik a római joggal (53. 186., 509., 576., 1010., 1376-1377.), köztük Justinianus már fentebb említett Institutioinak két kiadása, egy latinul és a jogász Hoffmann Pál 1864-ben megjelent magyar fordítása. A magyar szokásjog alapmủve, Werbőczy István Hármaskönyve két, 19. század közepi magyar kiadásban (1519-1520.), a Szónoklattan címü 1870-es Werböczy-kivonatban (1521.) és Okolicsányi János 1648-as lőcsei kiadásában (994.) szerepelt a könyvtárban. A könyvkatalógusban megtaláljuk a 16. század második felének neves francia politikai gondolkodója, Jean Bodin (164.), a 17. századi németalföldi jogász Hugo Grotius (607-608., 668.) és az ugyancsak 17. századi német jogász, politikai gondolkodó Samuel Puffendorf mủveit (538., 1098., 1178.). Az ELTE Egyetemi Könyvtár állományában azonosítottam a katalógusban 237. szám alatt szereplö, 1696-os kiadású Corpus juris Canonici példányát. Ez a könyv 1835-ben került Pauler tulajdonába, és feltehetően hozzá kapcsolható a fejezetkezdetek jelzése a hosszmetszésen (10. kép).

\footnotetext{
${ }^{6}$ Knapp Éva: Officium Rákóczianum. Az I. Rákóczi Ferencről elnevezett imádságoskönyv története és nyomtatott kiadásai. Budapest, Borda. 2000. 95. tétel.
} 


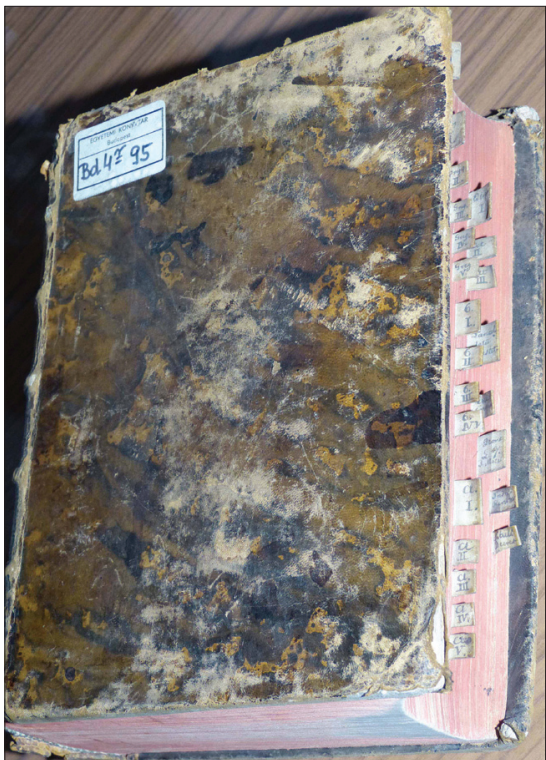

10. kép. Az 1696-os kiadású Corpus juris Canonici

A jogi irányultság mellett bizonyos természettudományok iránti érdeklődés is megfigyelhetö. Ezt Georges-Louis Leclerc Buffon Allgemeine Naturgeschichte (190.), két gimnáziumi tankönyv: Lutter Nándor Ferdinánd A természettan alaprajzának 2. javított és bővített kiadása 1853-ból (831.) és Szabó Ignác Természettani Földrajz (1350.) című művei mutatják. A különféle útikönyveket, várostérképeket és útleírásokat Pauler bel- és külföldi utazásaihoz szerezhette be és használta: 1. egy térkép van Graz-ról (1071.), kettő Bécsről (984., 1072.); 2. Freund Henrik orvos Harkány fürdőhellyel foglalkozó könyve 1871-ből (413.); 3. a Lloyd illusztrált útikönyvsorozatának a Bécstől Triesztig tartó utazást bemutató negyedik kötete (1500.); 4. a német ásványkutató, geológus Johann Gottlieb Lehmann Pozsonytól Nagyszebenig tartó útjának leírása (806.); és 5. a német régész és filológus, Ludwig Ross Wanderung in Griechenland címü müve (1169.).

A könyvtárból teljesen hiányoznak az orientalizmus és az egzotikum iránti érdeklődésre utaló müvek. Jelen vannak viszont a magyar nyelv és a magyarság eredetének kérdésével foglalkozó munkák: 1. az evangélikus lelkész, szabadkőműves Fessler Ignác Aurél 1794-ben Attila hun királyról írt művének 1809es német kiadása (392.); 2. a csehországi káplán és író Wilhelm Gärtner Attila címü, ötfelvonásos tragédiája (437.); 3. a katolikus pap, egyházi és történetíró, armenológus Lukácsy Kristóf $A$ magyarok öselei hajdankori nevei és lakhelyei eredeti örmény kútfők után címü 1870-es könyve (828.); és 4. a katolikus plébános Pátkai Seidel Pál A magyarok története címü 1872-es kötete (1281.). 
Nagyszámú és változatos a lexikon- és enciklopédiairodalom a könyvtárban. Ezeket valószínüleg általános segédletekként használta. A statisztika műveit is megszerezte Pauler, köztük a tudományág első hazai képviselőjének munkáját, Schwartner Márton Statistik des Königreichs Ungarn címü 1809-es, második, budai kiadását (1276.). ${ }^{7}$ A pszichológia egyik előfutára, a német filozófus Friedrich August Carus két könyve is megvolt a könyvtárban (209-210.). A neveléstörténettel és a magyarországi egyetemtörténettel foglalkozó mủvek is szép számban szerepelnek (232., 805., 1314.), például Kazy Ferencnek a nagyszombati egyetemtörténete (697.), Fejér Györgynek a Budára majd Pestre költözött egyetemről írt müve (381.), Mátrai Ernőnek a kolozsvári egyetemről írt könyve (902.) és Stockinger Tamás Beszéd a közmüvelödés és az egyetemekröl címü füzete (1322.). Ezeket is használhatta Pauler több egyetemtörténeti munkájához, például az 1880-ban megjelent A budapesti Magyar Királyi Tudomány-Egyetem története címủ müvéhez.

Végül említést kell tenni az egyetemes és a magyar irodalom szövegkiadásairól. Az antik görög és római szerzők jelenlétét már fentebb részleteztem. A bizánci, iszlám és a középkori európai vonatkozások teljesen hiányoznak a könyvtárkatalógusból. A reneszánsz irodalom némileg képviseltetve van, Boccaccio, Justus Lipsius és Machiavelli egy-egy müve (233., 618., 835.) révén, továbbá Kempis Tamás Krisztus követése egy francia és egy latin kiadásban az 1840es évekből (703., 1455.), valamint Shakespeare müvei német és magyar fordításban (804., 1283-1284.) szerepelnek a katalógusban. A barokk irodalomból megtalálható John Milton, Zrínyi Miklós és Esterházy Miklós egy-egy műve (928., 1615., 364.). A klasszicizmus és a felvilágosodás 18. századi irodalmából Montesquieu két (945-946.), Voltaire (967.), Rousseau (1179.), Lessing (811.) és Faludi Ferenc (374.) egy-egy müvel szerepel. A 18. századi magyar bölcselet, nyelv, történelem irodalmából Lethenyei János (812.), Kármán József (673.), Bél Mátyás (117.), Timon Sámuel (1435.) és Koppi Károly (745.) egy-egy, Pray György három (1090-1092.), és Kovachich Márton György négy müvel van képviseltetve (752-753., 755., 758.).

Goethe és kora irodalmát is kevés mü képviseli a katalógusban: Goethétől két sorozat 6 kötetben (463., 465.), Schillertől két sorozat 19 kötetben (1220 1221.), valamint Kotzebue és Walter Scott egy-egy müve (750., 1271.). A realizmus és a kortárs külföldi irodalom teljesen hiányzik a könyvtárkatalógusból. A 19. századi magyar szépirodalmat képviselik Csokonai Vitéz Mihály, Kölcsey Ferenc és Kisfaludy Károly minden munkái (260., 763., 713-714.), Jókai Mór A varchoniták címủ kisregénye (625.), Bajza József összegyüjtött munkái (79.), Petöfi Sándor versei 1845-ből (1057.), illetve Petőfi verseinek francia kiadása 1871-ből (1485.). Pauler két közeli kollégájának munkái is szerepelnek a katalógusban: a jogász és költő Császár Ferenc Öszi lombok címü verseskötete

\footnotetext{
${ }^{7}$ Vö. Buda, 2006, 540.
} 
1857-böl (254.) és a jogász, író Eötvös József három regénye (341., 346., 348.). Mindezek alapján arra következtetek, hogy Pauler latinul, németül, franciául és magyarul olvasott szívesen, angolul, olaszul feltehetően kevésbé tudott.

A könyvtárkatalógus tükrözi tulajdonosa különböző életszakaszait és világszemléletét. Megtaláljuk benne néhány ifjúkori tankönyvét, például egy 1827-es budai kiadású egykötetes Gradus ad Parnassum-ot (466.). Tekintélyes számban tartalmazta a könyvtár a jogi müveket, az országgyülés iratait, a 18. század végi szabadkőmüves könyveket és az aktuális politikai jellegü irodalmat. Összevetve Pauler könyvtárát kora újkori jogi könyvtárakkal és más 19. századi könyvtárakkal, szembeötlő az önálló szépirodalom csekély jelenléte. ${ }^{8}$ Ez nem azt jelenti, hogy a liberális katolikus ${ }^{9}$ Pauler ne olvasott volna szépirodalmat, csak az nem az 1872-es katalógusban rögzített jogi jellegü tudós szakkönyvtár része volt. A családnak bizonyosan volt könyvtára a badacsonytomaji villában is, ahol 1865-töl évtizedeken át a nyári hónapokat töltötte. ${ }^{10}$ További kutatást igényel, hogy Pauler használta-e például a Magyar Tudományos Akadémia vagy a Nemzeti Casino könyvtárát. ${ }^{11}$

Pauler naplójegyzeteiben több feljegyzésben említi olvasmányait, amelyekből kiderül a szépirodalom iránti érdeklődése és fogékonysága. Az 1838-1848 között Zágrábban tanító Pauler 1845. augusztus 26-án leírja egy kirándulását az Adriai-tengerhez: „Mi pedig 1/2 1 [órakor] elutaztunk s a szép s elég kényelmes mellékúton Delniczénél a Lujza útra lépünk; - Károlyinál egy ép azelött megölt medvének bőrét látjuk; onnan elutazván [...] Oszop mellett Ravnodolye nevü helyen elérjük a legmagasabb fokát 2936. láb a tenger fölött, majd nemsokára Jelenjénél (2785 1/2 1.) szemeim előtt az adriai tenger Kvarneri öble elterül; [...] élénken emlékszem Grünnek a tengerröl írt gyönyörü költeményére, $[\ldots]$ mélyen kedélyemre hat". ${ }^{12}$ Pauler itt minden bizonnyal Anastasius Grün német költő és politikus valamelyik versére utal. ${ }^{13}$

\section{Rezümé}

Pauler Tivadar egyetemi tanár, vallás- és közoktatásügyi, majd kétszer igazságügy miniszter és a Magyar Tudományos Akadémia tagja volt. A 19. század második felének meghatározó jogásza, élete és munkássága viszonylag jól feltárt, noha az Országos Széchényi

${ }^{8}$ Szabó Béla: Jogászaink olvasmányai a kora újkorban. = Iskolakultúra, 7. évf. 1997. 5. sz. 23-34. p. és a 4. lábjegyzetben jelzett szakirodalom.

${ }^{9}$ Pauler Tivadar ultramontánságáról: A budapesti társaság. Budapest, Pallas. 1886. 35-42. p.

${ }^{10}$ Kalmár László: Hogyan került Pauler Ákos Badacsonyba? = Badacsony, 19. évf. 5. sz. (2009. május). 6. p.

${ }^{11}$ Arany János könyvtárhaszálatáról ld. Bibor Máté János: Az Egyetemi Könyvtár Arany János kéziratai. $=$ Egyetemi Könyvtár Évkönyvei, 16. 2013. 223-248. p.

${ }^{12} 29$.f. verso.

${ }^{13}$ Pl. Am Strande, Auf dem Meere. Grün, Anastasius: Gedichte. Leipzig, Weidmann, 1841. 118-119., 154-156. p. 
Könyvtár Kézirattárában őrzött, mintegy 800 f. terjedelmü, 1845-től haláláig vezetett naplója máig kiadatlan. Lelkes könyvgyüjtő volt, könyvtárában ritka és értékes művek voltak, amelynek katalógusa fennmaradt az ELTE Egyetemi Könyvtár Kézirattárában őrzött hagyatékának dokumentumai és személyes tárgyai között. A több mint ezerhatszáz tételes könyvtárkatalógus 1872-ben készült, amikor Pauler ötvenhat éves volt. A könyvtár fö gyüjtőköre a jogi szakirodalom volt, de mutatja tulajdonosa érdeklődését a történelem, az irodalom, a szabadkőmüvesség, a vallás és az utazás iránt is.

Nemcsak a könyvtárkatalógus, hanem a könyvállomány egy része is megvan az ELTE Egyetemi Könyvtárban és más magyarországi egyetemi könyvtárakban. Az ELTE Egyetemi Könyvtárban található kötetek azonosítása nem egyszerü: egyesekben Pauler saját kezü, fekete tintával írt possessor bejegyzését találtam, másokban pedig a feltehetően a könyvtárba kerüléskor beírt ceruzás „Pauler” bejegyzés olvasható. Némely kötet korábbi tulajdonosa Zelenay János József, a nagyszombati egyetem jogi karának tanára. Más könyvek korábban a nagyszombati jezsuita kollégium tulajdonát képezték. Egy könyv korábbi tulajdonosa Caspar Gilbert Mellerstad stettfeldi plébános volt. További köteteket a „Pauler Tivadaré" bélyegzőcímke azonosít a pécsi, a szegedi és a debreceni egyetemi könyvtárban.

\section{The 1872 catalogue of Tivadar Pauler's library specialized in law}

Lawyer and university professor Tivadar Pauler held the position of Minister of Religion and Education once, and Minister of Justice twice, and he was a member of the Hungarian Academy of Sciences as well. He was one of the major lawyers of the second half of the $19^{\text {th }}$ century, his life and works have been studied sufficiently, however his diary is yet unpublished. He was an avid book collector, and left a library of rare and valuable works, the catalogue of which still exists among his documents and personal bequest in the ELTE University Library, Budapest. The library catalogue was made in 1872, when Pauler was fifty-six years old. It contains more than one thousand and six hundred books. The catalogue is dominated by the presence of law books, but shows also the interest for history, literature, Freemasonry, religion and travelling.

Not only the library catalogue, but also a part of the book collection exists in the Budapest University Library and in other university libraries in Hungary. The identification of the books available in the Budapest University Library is not easy at all: I found Pauler's handwritten possessor mark written with black ink in some books, and the mark 'Pauler' written with pencil can be read in others, probably entered when the books got to the library. Professor of the Nagyszombat University Faculty of Law, János József Zelenay was the former owner of some books. Other books were previously owned by the Jesuit College of Nagyszombat. The former owner of one book was Caspar Gilbert Mellerstad, Vicar of Stettfeld. Other books have been identified by the stamp label 'Pauler Tivadar's' in the libraries of Pécs, Szeged and Debrecen Universities.

TÜSKÉS ANNA

tudományos munkatárs

MTA BTK Irodalomtudományi Intézet 



\section{A Hevenesi-, Kaprinai-, Pray-kéziratgyüjtemény feldolgozásának kérdései}

A tanulmány szerzőjének egy korábbi, Hevenesi-, Kaprinai-, Pray-kéziratgyüjteményről szóló dolgozatában ${ }^{1}$ (felhasználva Knapp Éva e tárgyban született írásait² rövid összefoglalás olvasható a gyüjtemény általános jellemzőiről, forrásértékéről, az ELTE Egyetemi Könyvtár tulajdonába kerülés mikéntjéről és a lehetséges vizsgálati területekről. A jelen írás elsősorban a kéziratos gyüjtemények összetételére, valamint a könyvtári feldolgozásuk során alkalmazott módszerre fókuszál.

Az egyes kötetek tartalmát és összetételét Hóman Bálint ismerteti ${ }^{3}$ részletesen, bár ennek megjelenése óta néhány kötet máshová került az Egyetemi Könyvtár gyüjteményében (erről részletesen Tóth András számol be a „Holt” kéziratgyüjtemények élete 4 címü munkájában). Tóth András írását ${ }^{5}$ követően a Pray-gyüjtemény 11 kötettel gyarapodott, amelyek a Coll. Pray 61-71. jelzet alá kerültek. Az Egyetemi Könyvtár 1996 decemberében visszaadta a Cod. lat. 113. jelzetủ kódexet ${ }^{6}$ a Pannonhalmi Főapátság Könyvtárának, mint eredeti őrzőhelynek (amely a Főapátság gyüjteményében a Pannonhalmi Evangelistarium címmel található), tőlük pedig ide került Pray fent említett 11 kötetnyi forrásgyüjtése. ${ }^{7}$

Mivel az oklevélmásolatok egy meghatározó részét adják a gyüjteménynek ${ }^{8}$, érdemesnek tünik megvizsgálni, hogy valójában mennyi az oklevelek és okle-

${ }^{1}$ Mátyás Melinda: Jezsuita tudósok digitalizált kéziratgyüjteményei az ELTE Egyetemi Könyvtárban és lehetséges kutatási témáik = Valóságos könyvtár - könyvtári valóság. Szerk. Kiszl Péter, Boda Gáborné Köntös Nelli. Budapest, ELTE BTK Könyvtár- és Információtudományi Intézet. 2017. megjelenés alatt

${ }^{2}$ Knapp Éva: A Kézirat- és Ritkaságtár tudományos ismertetője. = Az Egyetemi Könyvtár története és gyüjteményei. Szerk. Szögi László. Budapest, ELTE Eötvös Kiadó. 2008. 191-216. p. Knapp Éva: A Budapesti Egyetemi Könyvtár Kézirattárának Levélgyüjteménye. = Az Eötvös Loránd Tudományegyetem Egyetemi Könyvtárában és Egyetemi Levéltárában őrzött 1526 előtti oklevelek és iratok jegyzéke. Szerk. Sölch Miklós. Budapest, ELTE Egyetemi Könyvtár. 2005. 33-36. p.

${ }^{3}$ Hóman Bálint: Kishevesi Hevenesi Gábor. = Történetírás és forráskritika. 2. köt. Hóman Bálint. Budapest, Attraktor. 2003. 321-332. p.

${ }^{4}$ Tóth András: „Holt" kéziratgyüjtemények élete. = Magyar Könyvszemle, 1958. 42-50. p.

${ }^{5}$ Tóth András i.m.

${ }^{6}$ Tóth Péter: Catalogus codicum latinorum medii aevi Bibliotheca Universitatis Budapestinensis. Budapest, 2008. https://edit.elte.hu/xmlui/bitstream/handle/10831/32258/Toth\%20Peter Catalogus\%20codicum\%20latinorum\%20medii\%20aevi\%20Bibliotheca\%20Universitatis\% $\%$ Budapestinensis.pdf?sequence $=1$ \&isAllowed $=y \#$ page $=294$ (2016. október 25.)

${ }^{7}$ Bánhegyi B. Miksa: A Pannonhalmi Főapátsági Könyvtár. = Könyv és könyvtár, 19. évf. 1997. 19-33. p.

${ }^{8}$ Lsd. Borsa Iván: A magyar medievisztika forráskérdései. = Levéltári közlemények, 44-45. évf. 1973. 1-2. sz. 103-121. 
vélmásolatok aránya a jezsuita tudósok kéziratgyüjteményeiben. Ehhez Dedek Crescens Lajos katalógusát ${ }^{9}$ vettük alapul, és megjelöltük a kollekciók egyes köteteinél, hogy oklevélmásolatot tartalmaz-e a benne található kéziratok többsége vagy nem. Az kapott érték a vizsgálat módja miatt inkább megközelítő becslésnek nevezhető. Azt is figyelembe kell venni, hogy vannak hiányzó kötetek, amelyeket Dedek is említ a katalógusában: a Hevenesi-gyüjteményből két, a Prayból pedig négy kötet hiányzik. Összesítve azt az eredményt kaptuk, hogy a három gyüjteménynek körülbelül a fele oklevélmásolat; a kötetek számát tekintve pedig 145 kötet oklevélmásolat, 152 más típusú kézirat. Az egyes kollekciókat megfigyelve a Kaprinai B (negyedrét méretü iratok) tartalmazza a legtöbb oklevélmásolatot: 50 kötetet számlál, és 52, többségében más kéziratos anyagot tartalmazó egységet. A kettedrét méretű dokumentumokból álló Kaprinai A gyűjteményről elmondható, hogy föként az oklevélmásolatoktól különböző forrásokat tartalmaz: 39 kötetének nem oklevélmásolat a nagyobb része, és 15 kötet tartalmaz főként oklevélmásolatot. A Pray- és Hevenesi-gyüjteményekre vonatkozó számokat lásd a táblázatban (1. táblázat).

\begin{tabular}{|l|c|c|c|}
\hline \multicolumn{1}{|c|}{ A kéziratok jellege } & $\begin{array}{c}\text { Hevenesi (2 kötet } \\
\text { hiányzik) }\end{array}$ & $\begin{array}{c}\text { Kaprinai A és } \\
\text { B együtt }\end{array}$ & $\begin{array}{c}\text { Pray (4 kötet } \\
\text { hiányzik) }\end{array}$ \\
\hline oklevélmásolat a többség & 53 & 65 & 27 \\
\hline nem oklevélmásolat a többség & 36 & 52 & 29 \\
\hline
\end{tabular}

1. táblázat. Oklevélmásolat-arányok

Az oklevélmásolatok mellett a másik nagy forrásértékủ része a kollekcióknak az egyedi történeti kéziratok, ezek közül is kiemelhető néhány. Így Szamosközy István két műve: az Erdély története címü (Pentades) autográf kézirat, amely a Hevenesi-gyüjtemény 11. kötetében található (a Rerum Ungaricarum címü írásával együtt), és a Hebdomadis címủ írás VI-VIII. könyvének kézirata (Hevenesigyüjtemény 15. kötet). A kéziratok első kiadója az ELTE Egyetemi Könyvtár korábbi föigazgatója, Szilágyi Sándor volt, aki Szamosközy István történeti maradványai címmel jelentette meg a müveket. ${ }^{10}$ Magyar nyelven először Borzsák

${ }^{9}$ Catalogus manuscriptorum Bibliothecae Regiae Scientiarum Universitatis Budapestinensis. Tom. II. Pars 2. Catalogus litterarum originalium ac collectionis Hevenessianae et Prayanae. Budapest, 1894. http://hdl.handle.net/10831/32254 (2016. október 11.) és Catalogus manuscriptorum Bibliothecae Regiae Scientiarum Universitatis Budapestinensis. Tom. II. Pars 3. Catalogus collectionis Kaprinayanae. Budapest, 1907. http://hdl.handle.net/10831/32256 (2016. október 25.)

${ }^{10}$ Szamosközy István történeti maradványai 1566-1603. (Monumenta Hungariae Historica. II. Scriptores. XXI. és XXVIII.). Kiadta: Szilágyi Sándor. Budapest, 1876; XXIX. Budapest, 1877 és Pataki József: Szamosközy István magyar nyelvű feljegyzései. = Erdélyi Múzeum, 53. évf. 1991. 1-4. sz. 154-157. p. 
István fordításában jelent meg válogatás a Pentades-ből ${ }^{11}$ és a Hebdomadis-ból 1963-ban, ${ }^{12}$. Szamosközy István volt az első magyar kutató, aki csak a forrásgyüjtéssel és történetírással akart foglalkozni, és ehhez módszeres levéltári kutatásokat folytatott ${ }^{13}$. A második kiemelt szerző Bzenszky Rudolf, az erdélyi anyag kutatója ${ }^{14}$, aki a Syllogimaea Transylvanae Ecclesiae per historiophilum címü mü írója. Fontos még megemlíteni Paulus Rittert, akinek a Natales D.(ivo) Ladislavo R.(egi) Slavoniae Apostolo Restituti címü írását őrzi kéziratosan Hevenesi 75. kötete (Dedek-katalógus szerinti 5. tétel). E münek az az érdekessége, hogy nyomtatásban a szakirodalom szerint egy példány maradt fenn, amely a zágrábi Nemzeti és Egyetemi Könyvtárban található, és valószínűleg 1704-ben került kiadásra ${ }^{15}$. A Pray-gyüjtemény 9. kötetében (Dedek szerinti 22. tétel) olyan érdekességekre is bukkanhatunk, mint Janus Pannonius levelezése, amelynek összeállítója valószínüleg Brodarics István volt ${ }^{16}$.

A máig teljességgel fel nem tárt gyüjtemények szempontjából a kutatást nagy mértékben segítheti, hogy a jelenleg Hevenesi-, Kaprinai-, Pray gyüjteményt képező kéziratos anyag teljességgel elérhető digitális formában. A kollekciók két forrástípusának kiemelése után nézzük meg röviden a digitalizálási munkát, és az azt követő javítási munkálatokat! A digitalizálás 2010-2011-ben történt az Arcanum Kft. közremüködésével. A kéziratoknál különösen fontos, hogy a lap minden része látható legyen a digitális másolaton (az eredetileg digitalizált képeken például szöveghiány volt a lap szélén, szamárfüles oldalak maradtak), ezért az Egyetemi Könyvtár munkatársainak koordinálásával célszerűnek tünt a körülbelül tíz százaléknyi, nem teljesen olvasható oldal újbóli szkennelése. Az egyes másolatok metaadatolására 2013-2014 között került sor egy NKA-pályázatnak köszönhetően. Ennek során feldolgozásra került az egész szkennelt anyag a Dedek-katalógus tételekre való bontása szerint. A tételek kiegészültek egy-egy példányadattal is, ez biztosítja, hogy vissza lehet keresni azokat a Dedek-katalógusban elfoglalt hely szerint. Ehhez ismerni kell az egyes gyüjtemények rövidítését a katalógusban: a Hevenesié collhev, a Kaprinai A-jé: collkapra, a Kaprinai B-jé collkaprb, a Prayféle pedig collpray. A jelzet további részei, amelyek szükségesek a pontos hely szerinti visszakereséshez: a kötet és a tételszám leírása három számjegyre kiegészítve: például, ha a Dedek-katalógus szerinti Kaprinai B 4. kötetének 12. tételét

${ }^{11}$ Szamosközy István: Erdély története. I. kiad. Budapest, Magyar Helikon. 1963; II. kiad. Magyar Helikon. 1977.

${ }^{12}$ Pataki József i.m.

${ }^{13}$ Hóman Bálint: Kishevesi Hevenesi Gábor. = Történetírás és forráskritika. 2. kötet. Hóman Bálint. Budapest, Attraktor. 2003, 321-332 p.

${ }^{14}$ Hóman Bálint i.m.

${ }^{15}$ Szörényi László: Paulus Ritter Szent László életrajza. = Irodalomtörténeti Közlemények, 103. évf.1999. 3-4.sz. 416-448. p.

${ }^{16}$ Ritoókné Szalai Ágnes: Janus Pannonius leveleinek kézirata a Pray-gyüjteményben. $=\mathrm{Az}$ Egyetemi Könyvtár évkönyvei, 14-15. évf. 2011. 283-291. p. 
keressük, akkor a következőt kell beírni a Gyüjtemény/jelzet keresőmezőbe az opac.elte.hu oldalon: collkaprb004_012*. A csillag karakterre azért van szükség, hogy az utána levő verzió-számozásra is keressen, ezzel bármely számú karaktert helyettesítünk. Ha lemarad a csillag, akkor is kapunk találatot: a Böngészésbe léptet a rendszer, ahol ki lehet választani a 12. tételt.

A feldolgozás során az idő rövidsége miatt a Dedek-katalógusból való adatrögzítés egy tömeges adatbevitellel történt, ezért szükséges az ekkor felvett és azonosított adatok átnézése és javítása, kiegészítése. A munka kezdetén a következő problémákkal, kérdésekkel szembesültünk:

a) Nehezen olvasható kézírások

b) Megbízható-e a másolat?

c) Hamisított oklevelek másolatai

d) A teljes egység végigolvasása nélkül meg lehet-e állapítani biztonsággal a metaadatokat?

e) Mi a könyvtáros és mi már a kutató feladata?

Az a) esetben jobban szükséges támaszkodni Dedek leírására, és a kéziratolvasási tapasztalatok alapján lehetséges hozzátenni, ami még bizonyossággal kiolvasható. Például Kaprinai István nagyon sok oklevelet másolt maga, szerencsére az ő kézírása igen szép és olvasható. A b) felvetés jogosságát alátámasztja például Szentgyörgyi Rudolf tanulmánya ${ }^{17}$, amelyben elvégzett egy gondolatkísérletet arról, hogy mi lett volna, ha A tihanyi apátság alapítólevele csak a korai kéziratos oklevélgyüjteményekben maradt volna fent. Kutatásából kiderült többek között, hogy a vizsgált szövegrészletek az egyik Kaprinai-másolatban (64. kötet: 36-43.) találhatók meg nem megbízható formában. Ez a szempont, valamint a c) és a d) felvetések óvatosságra intenek a feldolgozásban annak tekintetében, hogy mit tüntessünk fel a katalógusban azonosított adatként, és mit ne. A másolatokban található összes személynév és helységnév azonosítása például valószínüleg nem járható út, egyrészt mivel ez túlmutatna a könyvtárosi feladatokon, másrészt a meglévő eszközeinkkel nem, vagy csak indokolatlanul nagy időráfordítás révén tudnánk megbízhatóan megállapítani.

E szempontok figyelembevételével az adatok gazdagításához a Diplomatikai Levéltár és Fényképgyüjtemény (DL-DF) mintájára a következő típusoknak a javítását, kiegészítését tüztük ki célul a középkori oklevélmásolatok esetében:

a) A kiadó/kibocsátó: ezt az adatot többnyire Dedek is azonosítja, és mivel általában ismert történelmi személyről vagy intézményről van szó, biztonsággal fel lehet venni a helyes alakját. Az elektronikus katalógusban ezt a 700-as MARC-személynévmezőben rögzítjük.

b) A másolat eredetijének keletkezési helye és ideje: az év általában szerepel a Dedek-katalógusban is. A rendszerint a másolat végén szereplő teljes

${ }^{17}$ Szentgyörgyi Rudolf: Korai oklevélgyűjteményeink nyelvtörténeti forrásértékéröl. = Helynévtörténeti tanulmányok. 2013. 9. sz. 77-88. p. 
keltezést kiolvassuk (szükség esetén feloldjuk a középkori dátumot), és ezt adjuk meg az egyik megjegyzés mezőben (599). Ha van helynév is, akkor a következőképpen: Helynév, év. hónap. nap., például: Buda, 1492. január 10. Bizonytalanság esetén feltüntetjük e mögött zárójelben a másolaton szereplő keltezést a szövegben álló formában. A rendszer sajátosságai miatt az itt leírt pontos dátumra csak akkor tudunk keresni az elektronikus katalógusban, ha pontok nélkül(!) fogalmazzuk meg a keresőkérdést, például: 1476 július 10

c) A másolat eredetijének keletkezési idejéhez kapcsolódóan feltüntetjük a jobb keresés, szükítési lehetőség biztosítása érdekében a szerepeltetett dátum évszázadát az egyik tárgyszó mezőben (653).

d) Megjegyzések: ha egyéb információt ki tudunk olvasni bizonyossággal a kéziratból, akkor azt rögzítjük egy másik megjegyzés mezőben: például ha van adat a másolás idejéről, vagy egyéb egyedi információ kerül elő. A fent megadott kiegészítő adatok segíthetik a kutatókat abban, hogy könnyebben megtalálják az őket érdeklő kéziratokat. Ezenkívül van még két fontos cél, amelyeknek a megvalósításához remélhetőleg valamelyest hozzájárul a digitalizált kéziratgyüjtemény és sajátos feldolgozása. Ezek a Borsa Iván által vázolt levéltáros feladatok, az egyik, hogy be kell azonosítani a másolatok közül azokat, amelyeknek nem maradt fenn az eredetije, a másik a másolók által használt források azonosítása. ${ }^{18} \mathrm{~A}$ fent vázolt katalogizálási mód támogathatja az első feladatot (a dátum és a kibocsátó alapján már utána lehet keresni az oklevélnek), a másodikat pedig a Dedek-katalógusból származó és a rekordokba felvett információ segítheti: ha meg volt jelölve a másolás helye, akkor az bejegyzésre került Dedek írását átvéve az egyik megjegyzés mezőbe.

A másolás helyének megjelölése rendkívül ritka, az ilyen adatot tartalmazó tételek az alábbi táblázatban láthatók:

\begin{tabular}{|l|l|l|l|l|}
\hline Gyüjtemény & Kötet & Tétel & \multicolumn{1}{|c|}{ Dedek szövegének részlete } & Forrás helye \\
\hline Hevenesi & 55 & 1 & $\begin{array}{l}\text { Ex MS. in archivio archiepisc. Viennen- } \\
\text { sis asservato }\end{array}$ & Bécsi érsekség \\
\hline Hevenesi & 55 & 5 & Copiae ex arch. ep. Vien. factae & Bécsi érsekség \\
\hline Hevenesi & 55 & 6 & Copiae ex arch. ep. Vien. comparatae & Bécsi érsekség \\
\hline Pray & 3 & 1 & $\begin{array}{l}\text { Copiae instrumentorum praepositurae } \\
\text { Veteris Budae, descriptae ex originali- } \\
\text { bus, depositis et existentibus in capitulo } \\
\text { Posoniensi }\end{array}$ & Pozsony \\
\hline
\end{tabular}

${ }^{18}$ Borsa i.m. 


\begin{tabular}{|c|c|c|c|}
\hline Kaprinai B & 10 & $\begin{array}{l}\text { Documenta ex archivo Barthphensi, Po- } \\
\text { soniensi, Lelesziensi et ab aliis commu- } \\
\text { nicata }\end{array}$ & $\begin{array}{l}\text { Pozsony, Lelesz, } \\
\text { Bártfa }\end{array}$ \\
\hline Kaprinai B & 13 & $\begin{array}{l}\text { Continet literas et documenta ad histo- } \\
\text { riam Mathiae Corvini illustrandam per- } \\
\text { tinentia. Ex archivo Bartphensi, Casso- } \\
\text { viensi, et camera Posoniensi }\end{array}$ & $\begin{array}{l}\text { Kassa, Pozsonyi } \\
\text { Kamara, Bártfa }\end{array}$ \\
\hline Kaprinai B & 16 & $\begin{array}{l}\text { Continet documenta ad historiam Hun- } \\
\text { gariae illustrandam pertinentia, ex ar- } \\
\text { chivo Nagybanyaensi et Felsőbanyaensi } \\
\text { scribit et conexscripta }\end{array}$ & $\begin{array}{l}\text { Nagybánya, Fel- } \\
\text { sőbánya }\end{array}$ \\
\hline Kaprinai B & 18 & $\begin{array}{l}\text { Continet diplomata, partim ex analec- } \\
\text { tis Thomae Szirmai, partim ex sty- } \\
\text { lo cancellariae Mathiae temporibus } \\
\text { coaevo, partim ex autographis a Sa- } \\
\text { muele Székely communicatis, et ex ar- } \\
\text { chivo civitatis Eperjes }\end{array}$ & Eperjes \\
\hline Kaprinai B & 19 & $\begin{array}{l}\text { Complectit documenta ex archivo civi- } \\
\text { tatis Szakolczensis }\end{array}$ & Szakolca \\
\hline Kaprinai B & 20 & $\begin{array}{l}\text { Continet diplomata ex archivo familiae } \\
\text { Sosianae, Chakianae, Vecseianae, et ab } \\
\text { aliis Viennae communicata. }\end{array}$ & Bécs \\
\hline Kaprinai B & 27 & $\begin{array}{l}\text { Continet documenta, ex archivo civita- } \\
\text { tis Cassoviensis deprompta }\end{array}$ & Kassa \\
\hline Kaprinai B & 29 & $\begin{array}{l}\text { Complectit diplomata ex archivo fami- } \\
\text { liae Sztáray; ex Cassoviens. civit. tabu- } \\
\text { lario; ex libro documentorum collegii } \\
\text { Cassoviens.; ad Preaposituram Mislen- } \\
\text { sem pertinentia }\end{array}$ & Kassa \\
\hline Kaprinai B & 38 & $\begin{array}{l}\text { Continet copias potissimum ex archivo } \\
\text { Bartfensi desumptas. }\end{array}$ & Bártfa \\
\hline Kaprinai B & 40 & $\begin{array}{l}\text { Continet copias ex tabulario Bartphensi, } \\
\text { et e Bohemia submissa, imo et ex monu- } \\
\text { mentis familiae Fiatth deprompta }\end{array}$ & $\begin{array}{l}\text { Csehország, Bárt- } \\
\text { fa }\end{array}$ \\
\hline Kaprinai B & 42 & $\begin{array}{l}\text { Complectit documenta ex tabulariis } \\
\text { civit. Bartfa et Eperjes exscripta. Item } \\
\text { privilegia Ruthenis Episcopis et sater- } \\
\text { dotibus concessa }\end{array}$ & Bártfa, Eperjes \\
\hline
\end{tabular}




\begin{tabular}{|l|l|l|l|l|}
\hline Kaprinai B & 57 & $\begin{array}{l}\text { Maxima e parte continet varia privilegia } \\
\text { ad episcopatum Nitriensem pertinentia }\end{array}$ & $\begin{array}{l}\text { Nyitrai püspök- } \\
\text { ség }\end{array}$ \\
\hline Kaprinai B & 62 & $\begin{array}{l}\text { Continet potissimum literas historiam } \\
\text { conventus Lelesziensis tempore praepo- } \\
\text { sitorum: Blasii, benedicti Korny, Eliae } \\
\text { et Joanni illustrantes }\end{array}$ & Lelesz \\
\hline
\end{tabular}

2. táblázat. A források és helynevek Dedek katalógusa alapján

Az ötödik oszlopban a helyre vonatkozó Dedek-részlet látszik, az utolsóban pedig a hely kiemelése. Összesen tizennyolc olyan esetet találtunk, ahonnan kiemelhető volt a forrás helye. Ezek a hozzáfüzések mind szerepelnek az adott kötetek rekordjainál úgy, mint a Dedek-kötetre vonatkozó megjegyzések. Annak eldöntése, hogy mely rekordokra érvényesek a megjegyzések, tehát hogy a kötet egészére vagy annak egy részére vonatkoznak, már a kutatás feladata. Ezekben a szövegekben találunk néha arra is utalást, hogy mely család levéltárából származnak a másolatok, ez is hasznos lehet a kutatók számára.

A forrás helye mellett néhány esetben a másoló, átnéző vagy másoltató neve is megtalálható, melyek szintén hozzájárulnak a kötetek keletkezési körülményeinek jobb megértéséhez. A Dedek-megjegyzésekből való kigyüjtés szerint az alábbi személyeket találjuk e funkcióban (a nevek mellett a gyüjteményrész, amelynél szerepelnek):

- Pethő István SJ - Pray 3,1.

- Péterffy Károly SJ - Kaprinai A 7-10., 15., 17-23.

- Cseles Márton SJ, Péterffy Károly SJ - Kaprinai A 12-14.

- Timon Sámuel, Péterffy Károly SJ - Kaprinai A 16.

- Szemere Pál - Kaprinai A 27., 30.

- Schmidt P. Miklós - Kaprinai A 34-36.

- Timon P. Sámuel SJ - Kaprinai A 37-45., 50.

- Székely Sámuel - Kaprinai B 18.

- Kaprinai István, Terstyánszky János - Kaprinai B 19.

- Wágner Károly SJ - Kaprinai B 23.

- Révay Antal - Kaprinai B 52.

A nevek az előfordulás sorrendjében szerepelnek. A személyek többsége jezsuita. Közülük kiemelhető Székely Sámuel, aki biztosan nem tartozott a jezsuita rendhez, viszont régiséggyüjtőként baráti viszonyt ápolt Kaprinai Istvánnal, akivel forrásanyagokat is cserélt, ezt bizonyítja a fennmaradt levelezésük. ${ }^{19} \mathrm{~A}$ másolókról Hóman is ír az idézett tanulmányában. ${ }^{20}$

${ }^{19}$ M. Horváth Mária (sajtó alá rend.): Dobai Székely Sámuel és Kaprinai István levelezése. Piliscsaba, PPKE BTK. 2008. 117 p.

${ }^{20}$ Hóman i.m. 
Befejezésképpen nézzük meg, hogy milyen eredményeket kapunk, ha csak egy bizonyos időintervallumból származó oklevelek érdekelnek minket! Ezt egy összetett kereséssel tudjuk lekérdezni századok szerint a könyvtár nyilvános katalógusában. A keresőkérdés egyik eleme a keresendő évszázad, például 15. sz. (feltétel: Tárgyi mezők), a másik pedig a kollekció kódja: Kaprinai B 2. kötete esetében collkaprb002* (feltétel: Gyüjt./ Jelzet). A következő diagram ábrázolja az ilyen jellegü keresést századok szerint. A 15. század 6 másolat esetében jelenik meg.

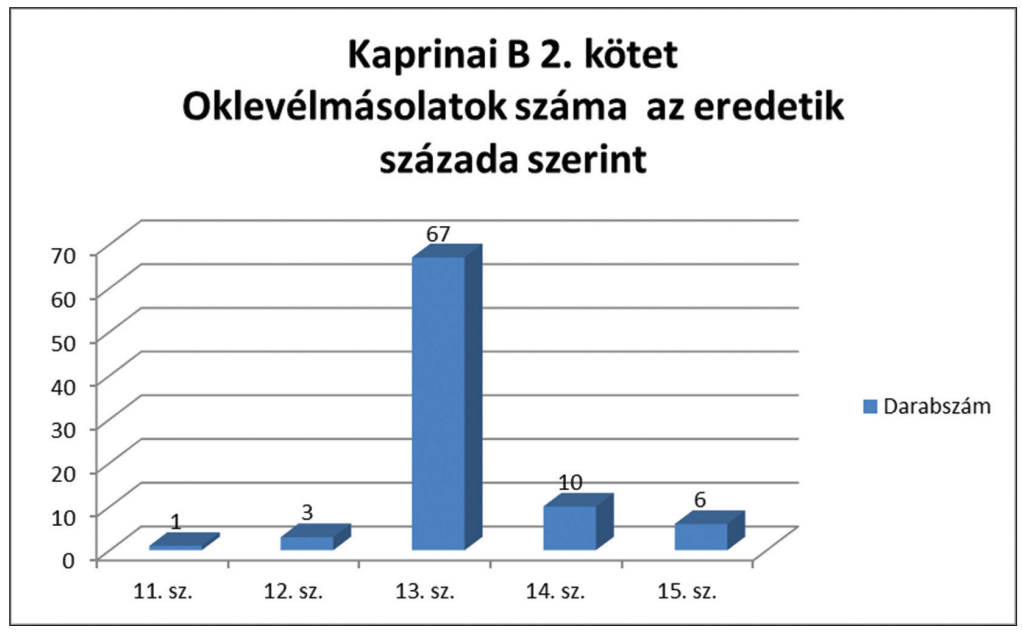

1. ábra. Századok szerint történő kimutatás - Kaprinai B 2. kötet

Ezt a lekeresést meg lehet tenni a jelenleg kiegészített, javított kötetnél (amenynyiben az oklevélmásolatokat tartalmaz), amelyek a mostani állás szerint a következők:

- Kaprinai B 2-3., 10-11., 13., 16., 19., 20., 37., 38., 44., 46., 61., 66., 70., 87.

- Pray 50.

A kötetek javítását és kiegészítését folyamatosan végezzük az integrált könyvtári rendszerben, mivel 12000 tételről van szó, ez hosszú távú feladat: az egy-egy történeti müvet tartalmazó kötet esetében gyorsabb, az oklevélmásolatokat, iratmásolatokat bíróknál időigényesebb (van amelyik kötetben több mint száz tétel található). Reményeink szerint ezzel közelebb hozzuk, kutathatóbbá tesszük az érdeklődők számára a kéziratos gyüjteményeket, és mind a Borsa Iván, mind a Tóth András által vázolt feladatok megvalósulását is elősegítjük, utóbbi azt foglalja magába, hogy szükséges lenne megállapítani, hogy mit publikáltak már a gyüjteményekből is mi az, amit még érdemes lenne közölni² ${ }^{21}$.

${ }^{21}$ Tóth András: Az Egyetemi Könyvtár kézirattárának fejlödése. = Egyetemi Könyvtár Évkönyve, 6. évf. 1972. p. 13-41. 


\section{Rezümé}

A tanulmány fó témái a Hevenesi-, Kaprinai-, Pray-kéziratgyüjtemények összetétele, valamint a könyvtári feldolgozásuk nehézségei és kihívásai. A kéziratok közül részletesebben foglalkozunk az 1526 előtti oklevélmásolatokkal, mivel a katalógusrekordok kiegészítését és javítási munkálatait ezzel a csoporttal kezdtük az Egyetemi Könyvtárban. Jelen írásban megismerkedünk továbbá a kollekcióban való keresés módjaival is és azzal, hogy a feldolgozás milyen speciális lekérdezési lehetőségeket kínál.

\section{The Problems of Cataloguing the Manuscript Collections of the Jesuit Scholars in the ELTE University Library}

The main topics of the paper are the structure of the Hevenesi, Kaprinai and Pray manuscript collections and the challenges of making their proper catalog records with a special regard to the diplomatic part of the collection (the collection of copies of medieval charters). We will describe also how to search easily in the collections and what kind of queries are offered to the users by this specific cataloging method.

MÁTYÁS MELINDA

informatikus könyvtáros

ELTE Eötvös Loránd Tudományegyetem Egyetemi Könyvtár ORCID: 0000-0003-0321-1658 



\section{A ELTE Egyetemi Könyvtár Vergerio-grammatikája (Cod. Lat. 23) ${ }^{1}$}

A könyvtár 2008-as katalógusa², valamint az Egyetemi Könyvtár 2008-as Mátyás király. Magyarország a reneszánsz hajnalán címü kiállítás katalógusának Wehli Tünde által jegyzett, e kódexre vonatkozó leírása kiválóan összegzi a „Vergerio-grammatika” legfontosabb adatait. Az említett müvek a kódex 1877es Magyarországra visszaérkezésekor készített első Csontosi János-féle leírásra, ${ }^{3}$ és az azóta végzett kutatásokra alapozva foglalják össze a kisméretű (192x130 $\mathrm{mm}), 108$ foliót tartalmazó könyv ismérveit. ${ }^{4}$ Pier Paolo Vergerio, ${ }^{5}$ mint feltételezett (meg nem nevezett) possessor azonosítása egy paleográfiai összevetés eredménye, amelyet Csapodiné Gárdonyi Klára végzett el a kódex f 108v-n található két sor (,,A. d. M.CCCC.XL. fui infirmus ad mortem, quod numquam per antea talem infirmitatem fui passus.") és Vergeriónak a velencei Biblioteca

${ }^{1}$ A tanulmány elkészítésében kapott segítségért szeretnék itt köszönetet mondani Cséka Györgynek és Cser Andrásnak.

${ }^{2}$ Catalogus codicum latinorum medii aevi Bibliothecae Universitatis Budapestinensis. Revisus et auctus per Petrum Tóth. Budapest, ELTE Egyetemi Könyvtár. 2008. http://hdl.handle. net/10831/32258 (2017. január 23.)

${ }^{3}$ Csontosi János: A Konstantinápolyból érkezett corvinák ismertetése. = Magyar Könyvszemle, 1877. 3-4, sz. 157-218. p.

${ }^{4}$ Tóth Péter im. 34-35. p.; Wehli Tünde: Latin nyelvkönyv - Pier Paolo Vergerio bejegyzésével. $=$ Mátyás király. Magyarország a reneszánsz hajnalán. Kiállítás az Egyetemi Könyvtárban, 2008. május 20. - június 21. Szerk. Bibor Máté János. Budapest, ELTE Egyetemi Könyvtár. 2008. 13. p.

${ }^{5}$ Pier Paolo Vergerio személyéröl és a magyar humanizmus születésében betöltött szerepéről: Banfi, Florio: Pier Paolo Vergerio il Vecchio in Ungheria, Archivio della Società Mattia Corvino (Supplemento a Corvina). = Corvina rivista di scienze, lettere ed arti della Societa unghereseitaliana Mattia Corvino, 3. évf. 1940. 1. sz. 1-30. p.; Huszti József: Pier Paolo Vergerio és a magyar humanizmus kezdete. $=$ Filológiai Közlöny, 1. évf. 1955.4. sz. 521-533. p.; Pajorin Klára: A magyar humanizmus Zsigmond-kori alapjai. = Mủvészet Zsigmond király korában, 1387-1437. Tanulmányok. Szerk. Beke László, Marosi Ernő, Wehli Tünde. Budapest, Művészettörténeti Kutatócsoport. 1987. 193-211. p.; Uő.: Mátyás király és a humanista nevelés. = Vigilia, 55. évf. 1990. 11. sz. 824-827. p.; Uő.: Vitéz János műveltsége. = Irodalomtudományi Közlemények, 108. évf. 2004. 5-6. sz. 533-540. p.; Solymosi Milán: Pier Paolo Vergerio e Coluccio Salutati. = Verbum, 4. Budapest, Akad. K., 2002. 147-163. p.; Kiss Farkas Gábor: A magyarországi humanizmus kezdeteiröl. Pierpaolo Vergerio, Vitéz János és Johannes Tröster. = Convivium Pajorin Klára 70. születésnapjára, Debrecen, 2012. 119-131. p.; Lengyel Réka: Egy Petrarcának tulajdonított Vergerio-hely a Szalkaikódexben, 1489/90 = Convivium Pajorin Klára 70. születésnapjára. Debrecen, 2012. 143-146. p.

Vergerio leveleinek kiadása: Pier Paolo Vergerio: L'Epistolario di Pier Paolo Vergerio, a cura di Leonardo Smith. Roma, 1934.

Pedagógiai mủvének legutóbb megjelent angol fordítása: Kallendorf, Craig W.: Humanist educational treatises. (The I Tatti Renaissance Library, 5). Cambridge, Harvard University Press. 2002. 
Nazionale di San Marco, Lat. Cl. XIV kötetében, az 54. fol. 101, 101 b helyen található írása között. Amint Csapodiné is megjegyzi azonban, ez az írás közel ötven évvel korábbi az 1440-es két sornál, tehát az identifikáció nem áll teljesen biztos lábakon. A megállapítás, miszerint ,,minthogy Vergerio 1444-ben halt meg, ez a négy évvel elöbbi közlés súlyos betegségéröl indokolt lehet" szorosan véve ugyancsak nem bizonyítja az olasz (isztriai) humanista és a könyv kapcsolatát. ${ }^{6}$

A másik, Vergerio possessor volta mellett felhozott érv a kódexben, a $\mathrm{f}$ 104v-n található levéltöredék, amelynek teljes átírását is megadja a katalógus: „Reuerende pater et domine mi, humiliter recommendo me vestre paternitati. Post humilem recomendacionem propositum notifico ad presens quod bene ualeo gracia saluatoris, quod idem affecto de vestra dominacione. Pridem superuenit filius vester presbiter Johannes quem affectuose interrogatus fui de uestra paternitate, qui nunciauit bonum nouum de vobis quod bene stabatis, quod summo fui alacer et in corde meo, per veritatem sublimam (sic) putabam uos vidisse istius (sic) diebus oculis corporis, ${ }^{7}$ sed fuit obstacio aliqua que constrinxit terminos ita quod ad presens non peregi quo tendebam, scilicet ${ }^{8}$ ad vos Carissime Domine quo intendebam vobiscum proferre de noue et nunquam audite alias. Sed huic est ad presens declinare aures vestras et intelligatis sane ut narrarem de nouis uerissimis. Et primo quantum ad congregacionem tocius concily generalis Constancie celebrati. Quod ibi sit totus mundus, quantum ad nobilitatem scienciam, prudenciam..."

A levélnek tehát sem a küldőjét, sem a címzettjét nem ismerjük, az egyetlen személy, akit névvel említ - Johannes presbiter -, nem azonosítható. A konstanzi zsinat (1414-1418) egykorú eseményként említése segít a datálásban, de nem kapcsolódik valójában ahhoz a tényhez, hogy Vergerio itt találkozott Luxemburgi Zsigmond királlyal, aki ezt követően Budára hívta.

Pajorin Klára Vergerio testamentumát elemezve megmutatta, hogy számos görög és latin könyvet is hátrahagyott, de ez az adat sem visz minket közelebb ahhoz a kérdéshez, hogy ez a kódex vajon valóban része volt-e az ő személyes könyvtárának.

A kódex tartalma latin grammatika, ami szintén nem személyes mü, hanem nyilvánvalóan tömegesen másolták. A felépítése és a szerkezete igazodik a korabeli latintanítás módszertanához: prózában és versben is memoriternek szánt szabályokat, és sokhelyütt a szabályos és szabálytalan alakok felsorolását tartalmazza. Itt kap szerepet egy közvetító nyelv, amelyet a jelen tanulmány igyekszik behatárolni.

${ }^{6}$ Csapodiné Gárdonyi Klára: A budapesti Egyetemi Könyvtár korvinái. = Magyar Könyvszemle, 1981. 3. sz. 224. p.

${ }^{7}$ A helyes olvasat: corporeis, bár ez nem változtat semmit.

${ }^{8}$ silicet.

${ }^{9}$ quia 
Az egyes szófajoknak és azon belüli kategóriáknak a grammatika hasábjain történő tárgyalását a véletlenszerủen kiválasztott $\mathrm{f} 95 \mathrm{v}$ lap alapján mutatom be. Itt az $i$-tövü fönevek ragozása szerepel: a lap tetején azokkal a fónevekkel kezdi a szerző a magyarázatot, amelyek singularis nominativus alakja -im-re végződik. Ezt egy hexameterből, minden bizonnyal valamelyik közkedvelt késő középkori verses grammatikából (Alexander de Villa Dei, Eberhardus Bethuniensis, Johannes Balbus) vette át. Az első három sorban közneveket sorol fel: vim, burim, pelvim, sitim, tussimque, caribdim..., aztán hozzáteszi, hogy vannak tulajdonnevek és görög jövevényszavak is: his qu(a)edam propria sociantur paucaque graeca / ut Tigrim Tibrim Tripolim Sirtimque eclipsim... majd megjegyzi, hogy ezek sem mindig követik a szabályt: inveniens turem verumtamen atque securem l et pelvem navem pupem testem quoque clavem. Itt következik a vis szó elragozása: Nominativo hec vis. Acusativo hanc vim. Ablativo ab hac vi. Et non habet plures casus in singulari, és ugyanezt megtoldja egy verssel: Vis vim vique dabit totum plurale tenebit. Miután ezt megtette, felsorolja ugyanazokat a föneveket, amiket a lap tetején, és glosszázza őket olaszul:

$\begin{array}{ll}\text { nominativo } h(\mathrm{aec}) \text { buris, ris } & \text { a la coda del aratro } \\ \text { nominativo } h(\mathrm{aec}) \text { pelvis, vis } & \text { a la chonca } \\ \text { nominativo } h(\mathrm{aec}) \text { sitis, tis } & \text { a la sete } \\ \text { nominativo } h(\mathrm{aec}) \text { tussis, sis } & \text { a la tosse } \\ \text { nominativo } h(\mathrm{aec}) \text { caribdis, dis } & \text { a un scoglio marino }\end{array}$

A többi -im végủ főnév, és minden más morfológiai kategória bemutatása hasonlóképpen zajlik a grammatika hasábjain.

Látható ebből, hogy sem a tartalom, sem a szerkezet nem visz közelebb a szerző vagy possessor személyéhez, és a kódex posztillái és margináliái sem vezetnek el személyesen Vergerióhoz. A lényegi tartalom mellett ugyanis csupán a már említett levelet (f 104v) és az 1440-es betegségről szóló bejegyzést (f 108v) találjuk benne, valamint az utóbbival egy lapon még néhány tollpróbának tủnő latin mondást és egy ószláv betükkel írott szöveget.

Az f 108v lap bejegyzéseire a következő, a jelenlegi leírástól némiképp eltérő olvasatot adom:

Ante Deum stantes non sitis corde uagantes Quia si cor non orat, in vanum lingua laborat. Disce puer mores bonos ut fratres honores. Sus desceno (?) magis desceno (?) gaudet quam fonte sereno. Ego sum vitis vera $>$ ave a $<$ gaudet ecclesia. Ave Maria. 
$\mathrm{Az}$ „Ante Deum stantes non sitis corde uagantes” szállóigének tekinthető, amely, mint a katalógus is utal rá, ${ }^{10}$ a Grazer Universitätsbibliothek 1128 -as kódexében is szerepel. Az internet segítségével azonban hamar rábukkanhatunk ugyanezekre a szavakra például egy Pominóból Oxfordba vándorolt Antonius Florentinus-féle Confessionáléban (Oxford Bodleian Inc 335), melyben talán a gyóntatáshoz használt segédkönyvbe kézzel bejegyzett emlékeztetőről van szó. Szállóige tehát, amely a latin nyelvtanba akár példamondatként is kerülhetett.

A szöveg további közmondásokkal folytatódik, ám ezeknek a grammatikával való kapcsolata már teljesen esetlegesnek tünik. A harmadik sor (Disce puer...) tartalmát tekintve is illeszkedik egy tankönyvbe, de a negyedikkel problémába ütközünk. A latin mondás jelentése 'A koca jobban örül a sárnak, mint a tiszta víznek', ám itt hallomás vagy másolás alapján kettős hiba csúszott az idézetbe: a 'de coeno' helyett feleslegesen kétszer a nem létező 'desceno' szó serepel. A Csontosi-féle első leírásban a sus szó helyett jus olvasat áll, ${ }^{11}$ és így nem is volt megfejthető a mondás. Végül az utolsó két sor egy bibliai idézet eleje ('Én vagyok az igazi szőlőtő'), ám két liturgikus felszólítással folytatódik: 'Örvendjen az Egyház!', illetve 'Üdvöz légy Mária!'.

A kódex keletkezési helyének meghatározásához egyedül a latintól eltérő nyelvü bejegyzések adhatnak támpontot, ahogy a katalógus is említi: „Provenientia: Italia (e scriptura et orthographia et multae exempla Italica (cf. ff. 29'-30' sicut losengar, ingienochiar se etc.) videtur)". ${ }^{12}$ A kódex tartalma megfelel a korabeli latin nyelvtanoknak, ám ott, ahol a magyarázatot vagy a szó jelentését nem latinul adja meg (mint fentebb már láttuk), sok mindent elárul a készítőjéről, másolójáról és használójáról.

Példaként az adverbiumok felsorolását mutatom be (ff 71v-76v), mert ez a nyelvfejlődésnek olyan területe, ahol mind szerkezeti, mind alaki téren jelentős átalakulások történnek. A grammatika elsőként itt is definíciót ad arra, hogy mi a határozószó, majd egy hosszú lista következik:

$\mathrm{f} 71 \mathrm{v}$

\begin{tabular}{|l|l|}
\hline nunc & adeso \\
\cline { 1 - 2 } hodie & anchuo \\
\cline { 1 - 2 } heri & \multirow{2}{*}{ ieri } \\
\cline { 1 - 2 } pridie & doman \\
\hline cras & impusinam \\
\cline { 1 - 1 } perendine & \multirow{2}{*}{ novela mente } \\
\cline { 1 - 2 } nuper & \\
\cline { 1 - 2 } noviter &
\end{tabular}

${ }^{10}$ Catalogus... id. mü, 34.p.

${ }^{11}$ Csontosi János: A Konstantinápolyból... id. mủ, 199.p.

${ }^{12}$ Catalogus... id. mü. 34.p. 
Az adeso és novela szóalakok degeminációja észak-olasz változatot jelent, amint a doman szóalak szóvégi magánhangzójának hiánya is. E jelenségeket a továbbiakban nem emelem ki a szóalakokból, szinten minden lapon ismétlődnek. A 'ma' jelentésủ anchuo alak az ófrancia-óprovenszálból átvett ancoi variánsa, a Tesoro della Lingua Italiana delle Origini (TLIO) adatbankban egyszer fordul elö, egy velencei dokumentumban. ${ }^{13}$ A novela mente adverbiális forma két szóba írása tükrözi az újlatin adverbium-képzés analitikus voltát.

f $72 \mathrm{r}$

\begin{tabular}{|c|c|}
\hline aliquando & alguna fia \\
\hline tunc & in quela fia \\
\hline comdam & de qua in drie \\
\hline olim & ça gran tempo \\
\hline dudum & \multirow{2}{*}{ longo tempo } \\
\hline diu & \\
\hline iam & ça \\
\hline semper & sempre may \\
\hline cur & \multirow{5}{*}{ per che } \\
\hline quare & \\
\hline quam obrem & \\
\hline quasobres & \\
\hline quadere & \\
\hline non & \multirow{7}{*}{ no } \\
\hline nichil & \\
\hline nec & \\
\hline haud & \\
\hline minime & \\
\hline nequaquam & \\
\hline ne & \\
\hline utinam & \multirow{2}{*}{ dio volesse } \\
\hline amen & \\
\hline optato & \multirow{3}{*}{ desiderose mente } \\
\hline optate & \\
\hline optanter & \\
\hline
\end{tabular}

${ }^{13}$ A Pietro Beltrami professzor vezette Opera del Vocabolario Italiano projekt szabadon használható TLIO adatbankjának internetes elérhetősége: http://tlio.ovi.cnr.it/TLIO (2016. október 1.) 
A fia alak az 'alkalom' jelentésủ, valószínúleg szintén ófrancia jövevényszó, a fiata észak-itáliai változata: a TLIO mantovai, milánói, genovai szövegekben regisztrálja. Egyes szavak jelentését szinte szófordulatokkal adja vissza a kézirat szerzője: a semper fordítását (sempre) megtoldja egy nyomatékosító may adverbiummal, az amen és utinam szavak fordítása, dio volesse jelentése körülbelül 'adja Isten'. A de retrum-ból származtatható drie alakban is velencei jellegzetességeket azonosíthatunk, konkrétan isztriai szövegekben mutatja ki a TLIO.

f $72 \mathrm{v}$

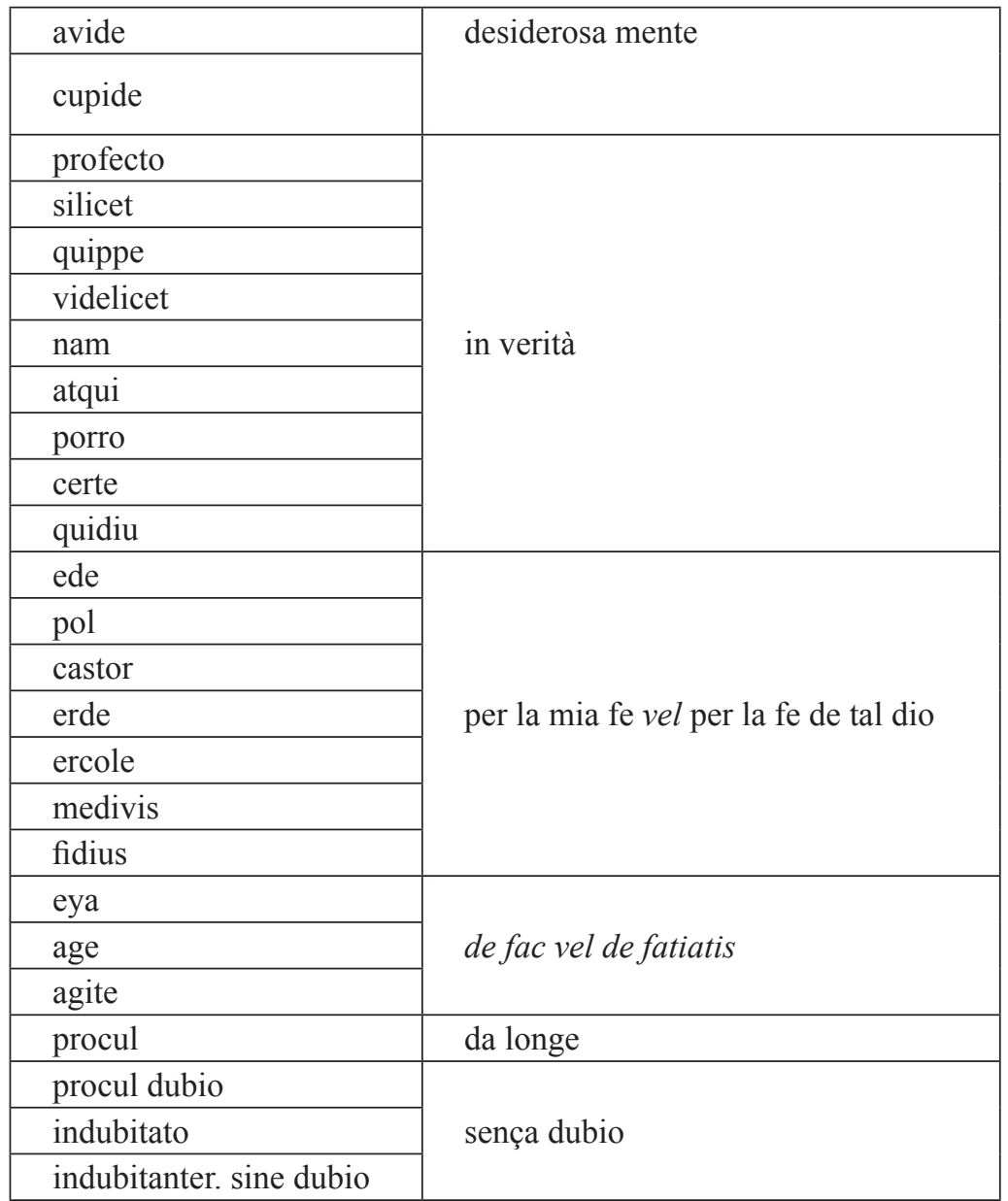

Az előző oldal végén és ennek a tetején 5 latin szinonímát sorol fel a 'remélhetőleg' jelentéshez. Ezen az oldalon a határozószavak között szerepelnek olyan indulatszavak is, amelyek a latin istenek nevéből származnak. Ezek fordításával nem sokat bajlódik a szerző, csak megjegyzi: 'hitemre vagy az adott isten hitére'. 
$\mathrm{f} 73 \mathrm{r}$

\begin{tabular}{|c|c|}
\hline vix & apena vel poco men \\
\hline paulatim & \multirow{2}{*}{$\begin{array}{l}\text { pienamente vel apuoco } \\
\text { apuoco }\end{array}$} \\
\hline paulatine & \\
\hline pede dentim & pepuspe vel tegnando pede \\
\hline comode & destra mente \\
\hline parce & temprade mente \\
\hline fere & \multirow{2}{*}{ puoco men } \\
\hline ferme & \\
\hline bene & ben \\
\hline male & mal \\
\hline docte & amaistrada mente \\
\hline pulcre & bella mente \\
\hline fortiter & forte mente \\
\hline suaviter & suave mente \\
\hline inpune & sença pena \\
\hline integraliter & intriega mente \\
\hline sane & sana mente \\
\hline liquide & \multirow{3}{*}{ manifesta mente } \\
\hline liquido & \\
\hline manifeste & \\
\hline rationabile & \multirow{3}{*}{ rasonivel mente } \\
\hline merito & \\
\hline meritorie & \\
\hline inrationaliter & \multirow{3}{*}{$\begin{array}{l}\text { non rasonivel mente vel sença } \\
\text { rason }\end{array}$} \\
\hline inmerito & \\
\hline demeritorie & \\
\hline
\end{tabular}

Erről az oldalról velencei szóként kiemelhető a docte megfelelőjeként az amaistrada mente, amely felbukkan például az Egyetemi Könyvtár Dante-kódexének függelékében is, egy XIV. századi latin-velencei kétnyelvű szólásgyüjteményben, amely Albertano da Brescia egy traktátusának kivonata. ${ }^{14}$ Ugyancsak

${ }^{14}$ Domokos György - Vida Máté: A budapesti Dante-kódex nyelve. = Egyetemi Könyvtár Évkönyvei. 12. köt. Budapest, ELTE Egyetemi Könyvtár. 2005. 35-60. p.; Domokos György: Il volgarizzamento veneto del Liber de amore di Albertano da Brescia in appendice al codice 
velencei szónak tekinthetjük a rason szót, a latin ratio megfelelőjét, amely itt több adverbium fordításában is szerepel. Érdekes kontaminációt mutat a pede dentim, ami valószínüleg a 'szorosan nyomonkövetve' jelentésü pedetemptim, pedetentim népi etimológiával elferdített változata.

f $73 \mathrm{v}$

\begin{tabular}{|c|c|}
\hline multum & molto \\
\hline parum & \multirow{2}{*}{ puoco } \\
\hline modicum & \\
\hline nimium & tropo \\
\hline satis & asai \\
\hline maxime & granda mente \\
\hline forsam & \multirow{4}{*}{ forse } \\
\hline forsitan & \\
\hline fortassis & \\
\hline fortasse & \\
\hline forte & \multirow{3}{*}{ per aventura } \\
\hline fortuitu & \\
\hline a casu & \\
\hline simul & \multirow{4}{*}{ insembre } \\
\hline una & \\
\hline pariter & \\
\hline adinvicem & \\
\hline festinanter & \multirow{8}{*}{$\begin{array}{l}\text { affreçada mente vel viagia } \\
\text { mente }\end{array}$} \\
\hline accelerate & \\
\hline celeriter & \\
\hline properanter & \\
\hline propere & \\
\hline velociter & \\
\hline concite & \\
\hline subito & \\
\hline
\end{tabular}

Ezen az oldalon szembeötlő az insembre szóalak, a mai toszkán-olasz insieme, 'együtt' adverbium változata, amely a francia ensemble hatása nélkül nehezen képzelhető el; Dante és Ariosto müveiben is előfordul. Az afreçada és viagia melléknévi alakok 'gyors' jelentéssel ugyancsak a venetói nyelvjárásokhoz köthetők.

dantesco. $=$ Dante Alighieri Commedia. Budapest Biblioteca Universitaria Codex Italicus 1. II. kötet: Studi e ricerche. Szerk. Pál József - Marchi, Gian Paolo. Verona, Szegedi Tudományegyetem - Universtità degli Studi di Verona. 2006. 99-116. p. 
$\mathrm{f} 74 \mathrm{r}$

\begin{tabular}{|c|c|}
\hline evestigio & \multirow{5}{*}{$\begin{array}{l}\text { affreçada mente vel viagia } \\
\text { mente }\end{array}$} \\
\hline extemplo & \\
\hline cumsubito & \\
\hline confestim & \\
\hline repente & \\
\hline mutuo & \multirow{4}{*}{$\begin{array}{l}\text { l'un con l'altro o mo l'un mo } \\
\text { l'altro }\end{array}$} \\
\hline alternantim & \\
\hline vicesim & \\
\hline alterutrum & \\
\hline regulariter & regular mente \\
\hline inregulatirer & \multirow{2}{*}{$\begin{array}{l}\text { non regular mente vel fuora } \\
\text { de rason }\end{array}$} \\
\hline enormiter & \\
\hline sordide & \multirow{2}{*}{ soça mente } \\
\hline turpe & \\
\hline dure & \multirow{2}{*}{ dura mente } \\
\hline duriter & \\
\hline plene & \multirow{2}{*}{ piena mente } \\
\hline penarie & \\
\hline latenter & \multirow{6}{*}{ aliegra mente } \\
\hline letabiliter & \\
\hline gaudiose & \\
\hline gaudenter & \\
\hline alacriter & \\
\hline ylarie & \\
\hline etiam & anche \\
\hline
\end{tabular}

A $74 \mathrm{r}$ lapon a 'most' jelentésủ mo alakot emelhetjük ki, amely a latin modo-ból származik. A 'felváltva' jelentésủ alternantim latin adverbiumot két körülírással tudja csak megadni a szerzö: l'un con l'altro, vagyis 'egyik a másikkal', illetve mo l'un mo l'altro, vagyis 'hol az egyik, hol a másik'.

$\mathrm{f} 74 \mathrm{v}$

\begin{tabular}{|l|l|}
\hline gradatim & de grado in grado \\
\hline annuatim & de anno in anno \\
\hline menstruatim & de mese in mese \\
\hline dietim & de dì in dì \\
\hline hostiatim & de porta in porta \\
\hline
\end{tabular}




\begin{tabular}{|c|c|}
\hline viritim & de homo in homo \\
\hline legaliter & lial mente \\
\hline item & \multirow{3}{*}{ anchora } \\
\hline aduc & \\
\hline rursus & \\
\hline nondum & \multirow{2}{*}{ non anchora } \\
\hline nonaduc & \\
\hline preterea & infra tanto \\
\hline non solum & \multirow{3}{*}{ non sola mente } \\
\hline nonsolumodo & \\
\hline nontantomodo & \\
\hline ordinatim & \multirow{3}{*}{ ordenada mente } \\
\hline seriose & \\
\hline seriatim & \\
\hline inordinate & desordenada mente \\
\hline nominaliter & \multirow{2}{*}{ per nome } \\
\hline nominatim & \\
\hline ubique & \multirow{2}{*}{ in hogni luogo } \\
\hline ubicumque & \\
\hline sollicite & sollicita mente \\
\hline
\end{tabular}

A 'fokról fokra', 'évről évre', 'hónapról hónapra' stb. jelentésủ adverbiumok megfelelője ismét csak körülírással lehetséges. Az ortográfiai norma hiányát mutatják a velencei glosszák, ezen az oldalon például a mai írásmódtól eltérő anchora (ancora) és hogni (ogni) alakok.

f $75 \mathrm{r}$

\begin{tabular}{|l|l|}
\hline atente & atenta mente \\
\hline antique & antiga mente \\
\hline antiquius & più antiga mente \\
\hline interim & \multirow{2}{*}{ infra tanto } \\
\hline interea & \multirow{2}{*}{ de l'una parte e d'altra } \\
\cline { 1 - 1 } utrinque & \multirow{2}{*}{ perpetual mente } \\
\cline { 1 - 1 } perpetue & \\
\cline { 1 - 1 } perpetuo & niente men \\
\cline { 1 - 2 } perhenim &
\end{tabular}




\begin{tabular}{|l|l|}
\hline ex quo & \multirow{2}{*}{ da posa } \\
\cline { 1 - 1 } postquam & entro li parlanti \\
\hline inter loquentes & almen \\
\hline saltem & saltando \\
\hline saltim & \multirow{2}{|c|}{ esser stado } \\
\cline { 1 - 1 } saltim saltando sed saltem dic minuendo \\
\hline asatise & \multirow{2}{*}{ divisa mente } \\
\cline { 1 - 1 } secus & \\
\cline { 1 - 1 } seorsus & \\
\cline { 1 - 1 } separatim & \\
\cline { 1 - 1 } secreto & \\
\cline { 1 - 1 } divisim &
\end{tabular}

A f 75r lapon olvasható alakok alapján megállapítható, hogy az észak-olasz nyelvfejlődésre egészen a mai dielaktusokig jellemző magánhangzók közötti zöngésedés több alakot is érint: antiga (antica) és stada (stata).

f $75 \mathrm{v}$

\begin{tabular}{|c|c|}
\hline trifariam & \multirow{2}{*}{ divisa mente } \\
\hline multifariam & \\
\hline quasi & \\
\hline ceu & \multirow{10}{*}{ cuscì } \\
\hline sic & \\
\hline sicut & \\
\hline sicuti & \\
\hline velud & \\
\hline veluti & \\
\hline ut & \\
\hline uti & \\
\hline ita & \\
\hline tale & \\
\hline inde & \multirow{4}{*}{ da possa } \\
\hline de inde & \\
\hline de inceps & \\
\hline continuo & \\
\hline protinus & da longe vel a postuto \\
\hline propterea & imperò \\
\hline
\end{tabular}




\begin{tabular}{|l|l|}
\hline albius & più biancha mente \\
\hline nigrius & più negra mente \\
\hline doctius & più amaistrada mente \\
\hline fortius & più forte mente \\
\hline sapientius & più savia mente \\
\hline solicius & \multirow{2}{*}{ più solicita mente } \\
\cline { 1 - 2 } actentius & \\
\hline
\end{tabular}

Ezen a lapon több fokozott határozószó is található, a fordítás megfelel a modern olasz szerkezetének, ám ezt három szóban írja a szerző. Meglepő a mai déli dialektusokra jellemző cuscì 'így' alak felbukkanása, és a 'később' jelentésnek megfelelö possa alak sem dokumentált a TLIO adatbázisban.

$\mathrm{f} 76 \mathrm{r}$

\begin{tabular}{|c|c|}
\hline plus & nì \\
\hline magis & piu \\
\hline minus & men \\
\hline $\tan$ & tantum \\
\hline quam & quantum \\
\hline maxime & grandissima mente \\
\hline doctisime & più amaistrada mente \\
\hline fortissime & fortissima mente \\
\hline albissime & biancha mente \\
\hline semel & una fia \\
\hline bis & do fia \\
\hline ter & tre fia \\
\hline quater & quatro fia \\
\hline quinquies & çinque fia \\
\hline sexies & sae fia \\
\hline septies & sete fia \\
\hline octies & oto fia \\
\hline novies & nove fia \\
\hline deties & diesci fia \\
\hline centies & cento fia \\
\hline millies & mille fia \\
\hline tonciens & tante fia \\
\hline quociens & quante fia \\
\hline multociens & molte fia \\
\hline meatim & a mio modo \\
\hline
\end{tabular}


Az adverbiumok között találjuk itt felsorolva a felsőfokú alakokat, bár a latin doctisime megfelelőjeként a szerző a középfokot jelentő più amaistrada mente alakot adja meg, ugyanazt, amit az előző lapon a középfojú doctius esetén. Utána számnevekből képzett határozószók sorjáznak, a már említett fia 'alkalom' jelentésü főnév segítségével körülírással.

f $76 \mathrm{v}$

\begin{tabular}{|c|c|}
\hline tuatim & a tuo modo \\
\hline suatim & a suo modo \\
\hline nostratim & a nostro modo \\
\hline vestratim & a vestro modo \\
\hline clam & \multirow{3}{*}{ ascosa mente vel piena mente } \\
\hline culum & \\
\hline belle & \\
\hline heus & \multirow{2}{*}{ „ella” clamare } \\
\hline hoo & \\
\hline heu & \multirow{2}{*}{ „o ben” respondere } \\
\hline ey & \\
\hline latenter & \multirow{2}{*}{ ascosa mente } \\
\hline oculte & \\
\hline licet & \multirow{2}{*}{ avegna dio } \\
\hline quamvis & \\
\hline ultra & \multirow{2}{*}{$\begin{array}{l}\text { oltra sed reperuit } \\
\text { prepositiones }\end{array}$} \\
\hline trans & \\
\hline decetero & \multirow{2}{*}{ da mo avanti } \\
\hline posterum & \\
\hline funditus & infina al fondo \\
\hline inprovise & \multirow{3}{*}{ desaviçuda mente } \\
\hline inproviso & \\
\hline inprovide & \\
\hline interim & \multirow{2}{*}{ infra tanto } \\
\hline interea & \\
\hline
\end{tabular}

Az adverbiumok hasznos szótárának utolsó lapján a módhatározók után érdekes módon a megszólítás és reagálás formulái szerepelnek. A heus és hoo megfelelöjének a szerző saját nyelvén az ella szót tartja, az erre való válasz latinul heu vagy ey, amit $o$ ben fordítással ad át. A desaviçuda mente alak 'hirtelen' jelentésü melléknévi elemét szintén ismerhetjük a Cod. Ital. 1 Albertano-szövegéből.

A fenti rövid tanulmány arra kívánja ráirányítani a figyelmet, hogy a kéziratok, kódexek keletkezési helyének és idejének meghatározásában milyen fontos szerep 
jut a nyelvi formák elemzésének. A latin nyelvtankönyvet tartalmazó Cod. Lat. 23, amelyet hagyományosan Vergerio-kódexként ismerünk, Itáliából származik, ahol a vulgáris nyelv térbeli és időbeli rétegzettsége szolgáltatja a legerősebb bizonyítékot, hogy a könyv a XIV-XV. századi velencei nyelv hatása alatt készült.

\section{Rezümé}

A ELTE Egyetemi Könyvtár Cod. Lat. 23 jelzetü kódexének Pier Paolo Vergerio személyéhez való kapcsolása olyan bizonyítékokon alapul, amelyek nem tekinthetök teljesen perdöntőnek. Ugyanakkor a kódex nem latin nyelvű bejegyzéseinek elemzése egyértelmủen bizonyítja a kézirat velencei származását.

\section{The 'Vergerio Grammar' of the ELTE University Library}

(Cod. Lat. 23)

The 'Vergerio Grammar' of ELTE University Library is linked to the person of Pier Paolo Vergerio by proofs that can't be regarded as fully certain. However the analyses of the language of Cod. Lat. 23 shows without doubt that the manuscript came from the area of Venice.

DOMOKOS GYÖRGY egyetemi docens PPKE BTK Olasz Tanszék 


\section{A Nemzeti Casino}

\section{A kulturális örökség}

Az utóbbi időben - fokozatos alakulás következtében - a kulturális örökség kulcsfogalommá nőtte ki magát a nyugat-európai kultúrpolitikában, és mindennapi életünk részévé vált. A fogalom körül tudományos viták alakultak ki az 1980-as évek elejétől fogva. Hazánkban kicsit megkésve, a Nemzeti Kulturális Örökség Minisztériumának létrejöttével, 1998-tól jutott a nyugat-európaihoz hasonló szerephez a politikai párbeszédben. Az örökség fogalma köré a 2000-es évek kezdetén már konferenciák szerveződtek. ${ }^{1}$

Az örökség-fogalom nemzeti szintü értelmezése a francia forradalom hatására alakult ki, a nemzeti örökség fogalmát Édouard Pommier hozta létre 1790ben. Az 1960-as évekig a történeti mủemlék a meghatározó, a régiség, a kor a döntő szempont. Ekkor jelentésbővülésen ment át a fogalom, megjelent az építészeti örökség, majd az 1970-es években a kulturális örökség a kollektív emlékezettel egészült ki, ezzel is gyarapítva a megőrzésre szánt csoportok körét.

Franciaországban az 1979-es levéltári törvény említi először az örökséget. Az Európa Tanács 1985-ös kongresszusa határolja körül a fogalmat, de a közös európai örökség fogalma már 1949-ben meghatározásra került. 1994-ben az Európai Helyi és Regionális Tevékenységek Kongresszusa meghatározta a helyi és regionális kulturális örökség körülhatárolásának, megörzésének az alapelveit. ${ }^{2}$

Mindezeknek és az UNESCO Világörökségi Központjának köszönhető, hogy „a kulturális örökség a legkisebb falusi közösségektöl az emberiség egészéig szervező elvvé vált, mely alkalmasnak tünik arra, hogy reprezentálja e közösségek identitástudatát."

„A kulturális örökség a közösség számára fontos jelentéssel bíró tárgyak vagy tárgyakkal kifejezett immateriális dolgok készlete." ${ }^{\prime 4}$ A tárgyakat a kijelölt intézmények gyüjtik, feltárják, őrzik és a közösség számára hozzáférhetővé teszik. Ezáltal a tárgyak kibővülnek a feldolgozó értelmezésével, eggyé válnak az emlékezettel, az örökséget és az emlékezetet együtt kell értelmezni. Mindkét fogalom az identitás része, ezt meg kell keresni, őrizni és ismét felfedezni.

A két fogalom összekapcsolódik egy harmadikkal, a történelemmel, de az örökség nem azonos sem a múlttal, sem a történelemmel. A múltnak csak egy

${ }^{1}$ Sonkoly Gábor: A kulturális örökség fogalmának értelmezései és alkalmazási szintjei. = Regio, 11. évf. 2000. 4. sz. 45 p.

${ }^{2}$ Erdösi Péter - Sonkoly Gábor: A kultúra melankóliája. A kulturális örökség fogalmának megjelenése. = Valóság, 48. évf. 2005. 6. sz. 74-75 p.

${ }^{3} \mathrm{im}$. Sonkoly G. 46 p.

${ }^{4}$ im. Sonkoly G. 47 p. 
válogatott és értelmezett része válhat a történelem részévé. Az örökség viszont az emlékezetbe vésett múlt átalakításából jön létre.

A kulturális örökség több szinten valósulhat meg, jelen van helyi, regionális, nemzeti és nemzetek fölötti szinten is. A különböző szinteken másképp valósul meg az örökség, és mást értenek alatta: a kulturális örökség nemzeti szinten nemzeti örökséget jelent, az Európai Unión belül a sokszínűséget hirdetik, melyre egy példa lehet a világörökségi helyszínek listája. Minden esetben meg kell határozni, hogy egy objektum mitől válik érdemessé arra, hogy ezt egy nagyobb közösség magáénak vallja.

Egy ilyen helyi vagy nemzeti kulturális örökségnek tekinthető a Nemzeti Casino.

\section{Nemzeti Casino}

Széchenyi István 1827-ben alapította meg a Nemzeti Casino-t (= NC), mely 1830-ig Pesti Casino néven müködött. Széchenyi az ünnepélyes megnyitón vázolta az egyesület célját, vagyis „hogy hazánkban is legyen egy olyan megkülönböztetett díszes összegyülekezőhely, melyen főbb és előkelőbb és jobb nevelésủek, eszes, értelmes férjfiak, a társasági rendnek mindenik osztályából egymással vagy barátságos beszélgetés végett találkozzanak vagy többféle politikai ujságokat s hasznos gazdasági, tudományos, mủvészi hónapos-írásokat olvashassanak, magukat pedig üres óráikban illendően mulathassák".5

Már ekkor 175 részvényese volt az egyesületnek. Bizottságot állítottak fel az alapszabályok kidolgozására és az egyesület ügyeinek intézésére.

Az NC szük körủ országgyülésként is müködött, az ülések után itt folytatódott a döntések megvitatása, mindez ellentétes volt az alapítók céljaival. A politizálás ellen többször is fellépett az NC igazgatósága. Ezt igazolja például Kossuth Lajos esete is, aki 1836-ban kérte felvételét az egyesületbe: „a nemzeti casino tömérdek hírlapot hordatott és szép könyvtára volt, szerettem volna hasznukat vehetni". Széchenyi személyesen kérte meg az új tagjelöltet, hogy vonja vissza a kérelmét, félt, hogy a bécsi udvar politikai lépésnek vélné. Kossuth visszavonult: „,..itt ön [Széchenyi] a házi gazda; én annak nézem, s nem szokásom oda tolakodni, ahol tudom, hogy nem szívesen látnak."

A Nemzeti Casino minden évben kiadta az aktuális alapszabályait, házirendjét és tagjainak a névsorát. Az NC nem exkluzív klubként jött létre. Köreibe tartoztak tisztviselők, táblabírák, ügyvédek, orvosok, tudósok, írók, kereskedők, gyógyszerészek. ${ }^{7}$ Szigorú szabályok vonatkoztak a kártyajátékra is. Amennyiben

${ }^{5}$ Ilk Mihály: A Nemzeti Casino százéves története: 1827-1926. Budapest, Franklin Nyomda. 1927. 8-9. p.

${ }^{6}$ Simon Zoltán: A reformkori magyar politikai nyilvánosság és a Nemzeti Kaszinó. $=$ Sic Itur Ad Astra, 12. évf. 2000. 3. sz. 38-40 p.

${ }^{7}$ im. Ilk M. 11 p. 
valamelyik tag nem törlesztette az adott határidőn belül a játékban felmerült tartozását, kizárhatták az egyesületből.

A Casino helyiségei, mint a társalgó, olvasóterem, játékterem és az étterem csak a kijelölt célokra voltak használhatók. A könyvtár dokumentumait - könyvek, folyóiratok, hírlapok, térképek, egyéb nyomtatványok - csak helyben lehetett használni, az olvasó- és a játékteremben tilos volt étkezni és csendben kellett lenni. Az éttermen kívül kizárólag este 10 óra után lehetett ételt felszolgálni. A helyiségek reggel 11 órától hajnali 5 óráig tartottak nyitva.

Gróf Széchenyi István végrendeletében a Casino-ra egy aranyserleget hagyott, és kérte, hogy „minden esztendőben tartassék ott egy részvényesi ebéd s akkor az én emlékezetemre üríttessék ki az említett serleg, mely az akkori borok leghelyesebbikével legyen meg- s megtöltve."

„A nemzeti Casino vagyona feloszthatatlan, és ahhoz se részvényesek, sem az egyletből kilépett tagok, sem azok örökösei, hagyományosai vagy engedményesei legkisebb jogot sem tarthatnak. Azon esetben, ha az egylet feloszlatása, emberi számítás szerint előre nem látható bármi rendkívüli okok vagy eseményeknél fogva, elkerülhetetlenül bekövetkeznék, összes vagyona, mint szintén feloszthatatlan alapítvány a magyar tudományos akadémia avagy az annak helyébe netán lépett hasonló jellegü magyar tudományos intézetre háramlik."”

\section{A Nemzeti Casino könyvtára}

1827-ben az NC megalapításakor Széchenyi felajánlotta 338 kötetes könyvtárát, ezzel megalapozta a gyüjteményt. A tagok ekkor még további 250 kötetet gyüjtöttek össze. ${ }^{10} 1829$-től a beszerzési keretet csak magyar müvekre lehetett fordítani. Az 1834-ben már 3000 müvet tartalmazó állomány többsége ennek ellenére idegen nyelvű művekből állt, köszönhetően a sok külföldi kötetet tartalmazó adománynak és hagyatéknak. ${ }^{11}$

A gyüjtemény magánjellegü könyvtárként jött létre, a tagok kizárólag helyben használhatták. Egy nagyterem, 3 szoba és egy olvasóterem szolgálta a könyvtár céljait. A nagyteremben a könyvállomány, a kisebb termekben a hírlapok sorakoztak. Több katalógus segítette az eligazodást: egy betủrendes cédulakatalógus (1873), egy szak szerinti cédulakatalógus (1873), egy index, melyben a könyvek és az új szerzemények szerepeltek betürendben és egy nyomtatott katalógus (1852). ${ }^{12}$

\footnotetext{
${ }^{8}$ im. Ilk M. 39-40. p.

${ }^{9}$ A nemzeti casino alapszabályai. 1895. 24 p.

${ }^{10}$ György Aladár: Magyarország köz- és magánkönyvtárai 1885-ben. 1886. 68 p.

${ }^{11} \mathrm{im}$. Simon Z. 42 p.

${ }^{12}$ Csontosi János: Emlékirat a Nemzeti Casino könyvtáráról. = Magyar Könyvszemle, 12. évf.
} 1887. 1-6. sz. 124 p. 


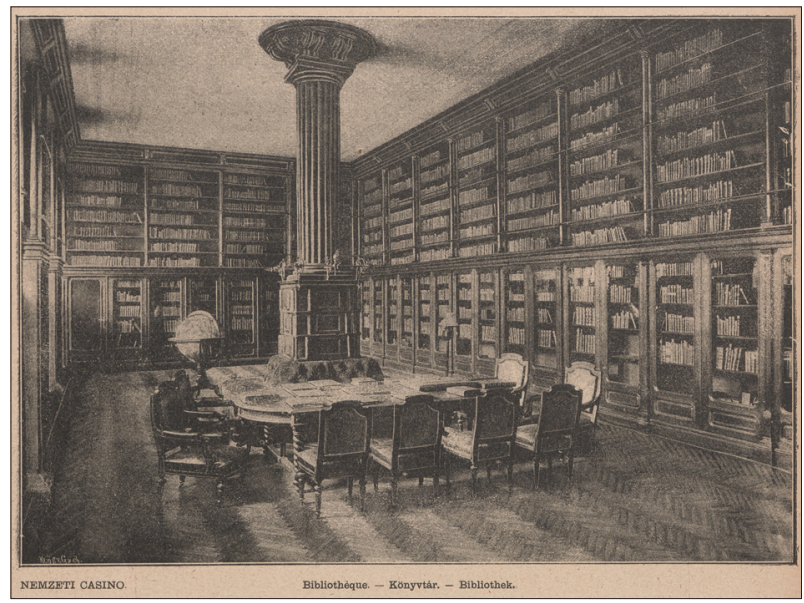

1. kép. A Nemzeti Casino könyvtára ${ }^{13}$

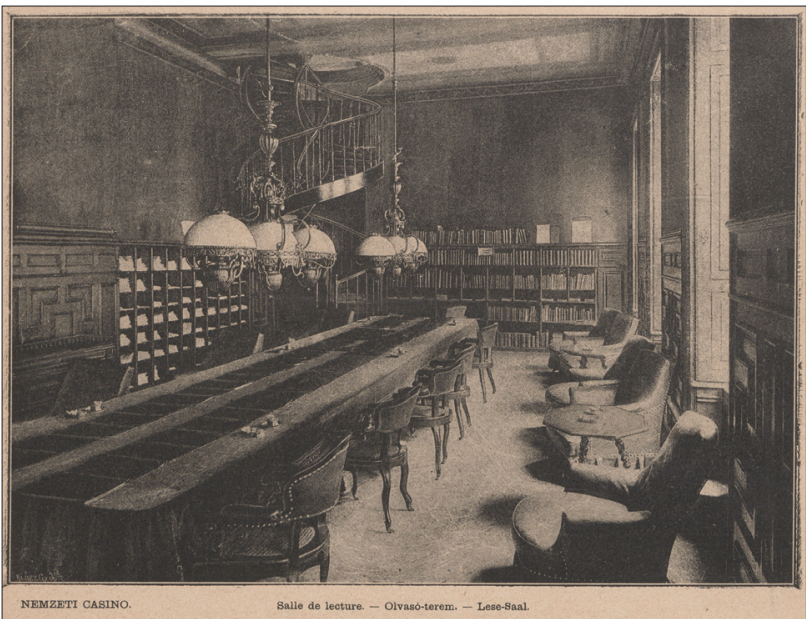

2. kép. A Nemzeti Casino olvasóterme ${ }^{14}$

A könyvtár főbb adományozói voltak gróf Dessewffy Aurél, Tasner Antal, Láng Ignácz, Weisz Bernát F., Szilágyi Ferenc, Török János. A megbízott könyvtárnokok nagy hangsúlyt fektettek a könyvtárra, „föntartása és kezelése a szakrendezés keresztülviteléig a könyvtártudomány és bibliographia igényeinek s az intézet traditióinak egyaránt megfelelt". ${ }^{15}$

${ }^{13}$ A kép forrása: http://ybl.bparchiv.hu/nemzeti-casino-konyvtar-klosz-gyorgy-fenykepe-nyoman (2016. október 16.)

${ }^{14}$ A kép forrása: http://ybl.bparchiv.hu/nemzeti-casino-olvaso-terem-klosz-gyorgy-fenykepenyoman (2016. október 16.)

${ }^{15}$ im. Csontosi J. 119 p. 


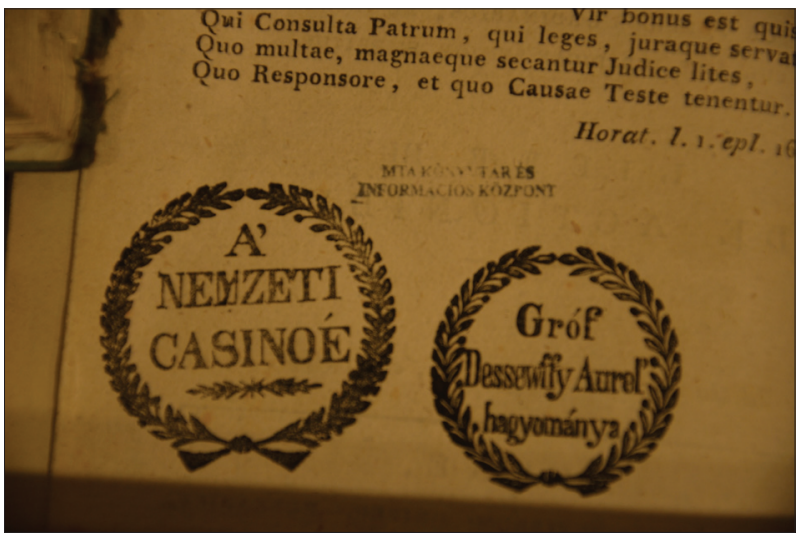

3. kép. Gróf Dessewffy Aurél pecsétje

A korabeli leírásokból megtudhatjuk, mit tartalmazott az állomány: „A könyvtár legnagyobb kontingensét a magyar irodalom termékei s a magyar történeti kútfők szolgáltatják. A könyvtár birja a m. t. akadémia s a Kisfaludy-társaság összes kiadványait, a magyar zeneiróknak legnagyobb részét s a magyar tudományos irodalomnak minden nevezetesebb termékét."16

1884-ben a helyben használók, 1800 tag, összesen 3210 kötetet olvastak. Az állományba tartozott 13 kézirat, két régi, 1711 előtti magyar nyomtatvány, 400 térkép, 1 földgömb, illetve egy régi festmény is. ${ }^{17}$

Az NC termeiben minden szaknál külön sorakoztak a magyar nyelven írt munkák, a Magyarországra vonatkozók és a külföldi irodalom termékei. A könyvtár osztályozási rendszere 1852-ben a következő volt: ${ }^{18}$

I.: Irodalomtörténet, Itészet (Mübírálat), Nyelvészet, Bibliográfia, Szótárak, Enciklopédiák;

II.: Klasszikusok, Szépirodalom, Müvészet, Régiségek;

III.: Filozófia, Nevelés, Iskolaügy, Vallás, Egyház, Mitológia;

IV.: Történelem, Életírás, Emlékiratok, Oklevéltan, Érmetan, Címertan, Genealógia;

V.: Földirat, Statisztika, Utazások, Helyrajzok, Népismertetés, Kalauzok;

VI.: Politika, Államtudomány, Közélet, Társadalom, Törvény- és jogtudomány, Büntetőügy;

VII.: Nemzetgazdaság, Pénzügy, Ipar, Kereskedelem, Közlekedés;

VIII.: Természettudományok, Orvostan, Baromorvoslat, Gazdaság, Földmüvelés, Állattenyésztés, Erdészet, Vadászat, Kertészet;

16 im. György A. 69. p.

${ }^{17} \mathrm{im}$. György A. 70. p.

${ }^{18}$ Pákh Albert [összeáll.]: Kalauz a’ Nemzeti Casino könyvtárához. Pesten, Trattner Nyomda. 1852. 259-313. p. 
IX.: Matematika, Csillagászat, Építészet, Kézmütan, Hadtudomány;

X.: Vegyesek.

Egy 1886-os jelentés szerint ez a „legrégibb és legtekintélyesebb ilynemü könyvtár az országban ... közkönyvtáraink közt is számot tesz.”19

\section{A feloszlatás}

A magyar belügyminiszter a 251.044/1945.IV./14 számú rendeletével feloszlatta az NC-t, mint ,az ország érdekeivel ellentétes müködést kifejtö jogi személy”-t. ${ }^{20}$ Ekkor a föváros megkezdte az egyesület vagyonának leltárba vételét és lefoglalását. Amint a Magyar Tudományos Akadémia (MTA) - mint az alapszabályok szerinti jogutód - tudomására jutott az eset, bejelentette igényét az örökségre, illetve jelezte együttmüködését és támogatását a kármentés folyamatában.

Az NC teljes vagyona ekkor:

a) két bombatalálatot kapott épület (Kossuth L. utca 5., Gellérthegy utca 5.)

b) ingó vagyon - tagok a háború elött vidékre mentették, többsége megsemmisült

c) NC iratai megsemmisültek a háborúban

d) könyvtár a romépületben

- 20.000-23.000 kötetet azonnal átszállítottak az Egyetemi Könyvtárba (1945. okt.), melyet 1947 júniusában továbbszállították az Akadémia épületébe

- a fennmaradó 6.000-10.000 kötet később került az Akadémia épületébe (1946. máj.)

- az értékesebb könyveket a háború előtt az Országház pincéjébe rejtették el, melyek ott elégtek

e) vadásztrófeák (Természettudományi Múzeumban örökletétként)

f) NC mutatói, osztálykatalógusai (jelenlegi lelőhelyük nem ismert)

A feloszlatást követő eseményekről részletes beszámoló áll rendelkezésre, de ugyanakkor a következő évtizedek történéseiről kevés az információ.

\section{Nemzeti Casino az Akadémia könyvtárában}

A könyvek kézbevétele hosszú évekig váratott magára. Az MTA könyvtárának éves jelentései időről időre említést tesznek az állományról, de mindig csak a könyvek rendezése kapcsán, a tételes feldolgozásra ez idáig még nem került sor. 1985-től rendszerezték a könyveket, eleinte könyvre és folyóiratra szétválogatva az anyagot, külön a magyar és az idegen nyelvüeket, majd szerzői betürend kialakítását kezdték meg. 1999-ben az MTA KIK Kézirattár és Régi Könyvek Gyüjteményének munkatársa, Mázi Béla egy rövid kéziratban foglalta össze az NC

${ }^{19}$ im. Csontosi. 118. p.

20 Ügyészi jelentés. 1945. MTA KIK Kézirattár és Régi Könyvek Gyüjteménye. RAL 234/1945. 
feloszlatásával kapcsolatos információkat. ${ }^{21} 2008$ körül újrarendezték az állományt, ekkor már az NC osztályszámai szerint.

Az állomány tényleges feldolgozása 2014 elején kezdődött meg. A köteteket a feladattal megbízott szakember letisztogatja, behasonlítja a korábbi NC művekkel, feldolgozza, digitalizálja a címoldalakat és a tartalomjegyzékeket, s ezeket csatolja a leírásokhoz, végül raktári jelzettel látja el.

Jelenleg a könyvtárban közel 17.700 NC-gyüjteményböl származó kötet található, és további 2.000 kötet van még a Magyar Nemzeti Múzeumban (= MNM). Feldolgozásuk megkezdése óta több mint 5.600 könyvrekord került be a könyvtár integrált könyvtári rendszerébe. A leírások a régi könyvek feldolgozási kritériumai szerint készülnek, figyelembe véve a könyvtár MARC 21-re épülö házi szabályzatát.

A rekordokban minden kötetnél jelöljük a kötés típusát, az összes kézírásos bejegyzést, pecséteket, bélyegzőket, fizikai hiányosságokat, sérüléseket.

Az eddig összesen elkészült 5684 rekordból 1759 idegen nyelvü mü leírása. A magyar nyelvủ osztályokba tartozó kiadványok már feldolgozásra kerültek. A külföldi könyvek jelentős hányada az eddigi feldolgozás tanúságai szerint német nyelvü volt, de akadt néhány francia, angol, latin és olasz is. A kötetek többsége a 19. században, illetve a 20. század elején jelent meg. A régi könyvek közül 790 darab 1850 elötti magyar (ebből 15 db 1800 előtti), és 6 darab 1800 előtti idegen nyelvü leírás készült.

Megtörtént a folyóiratok elkülönítése a könyvektöl, jelenleg összesen 5.774 folyóiratszám (449 cím) szerepel a rendszerben.

A munka során megtörtént a penészesnek tünő kiadványok leválogatása. Külső szakemberek megállapították, hogy nem élő penészről van szó, ezért fölöslegessé vált az elkülönítés. A hányatott sorsú állományban sok példány sérült, hiányos, keresztüllőtt, és néha még a lövedékek is a kötetben maradtak.

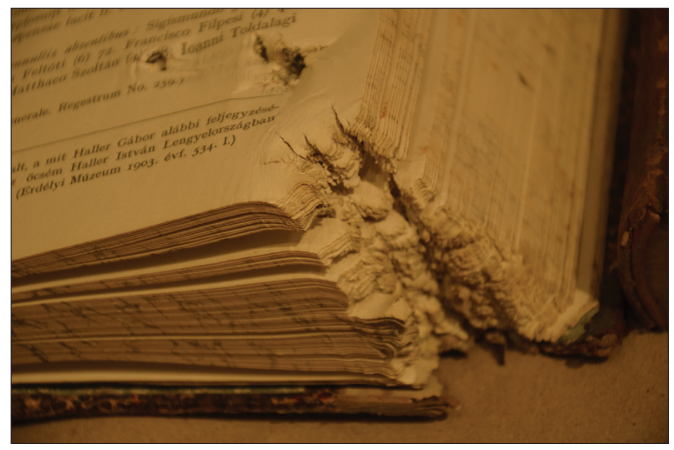

4. kép. Egy sérült kötet

${ }^{21}$ Mázi Béla: A Nemzeti Kaszinó könyvtára a Magyar Tudományos Akadémia Könyvtárában. Kézirat. Budapest, 1999. 
A kötetek többnyire félbőr vagy félvászon kötésủek, egységes stílusúak. A gerincen aranyozva legtöbbször a Nemzeti Casino, N. Casinoé vagy az N.C. szerepel. Minden könyvben megtalálható az NC exlibrise és legalább egy pecsét.

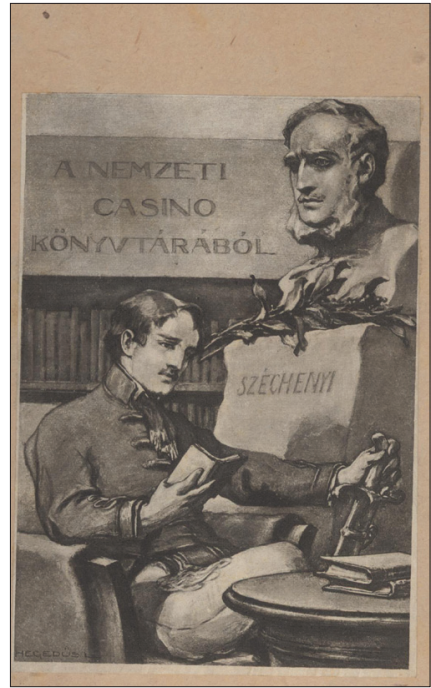

5. kép. Az NC exlibrise

Sokszor többféle pecsétet is tettek egy mübe, és előfordul, hogy minden fejezet végén található egy pecsét.
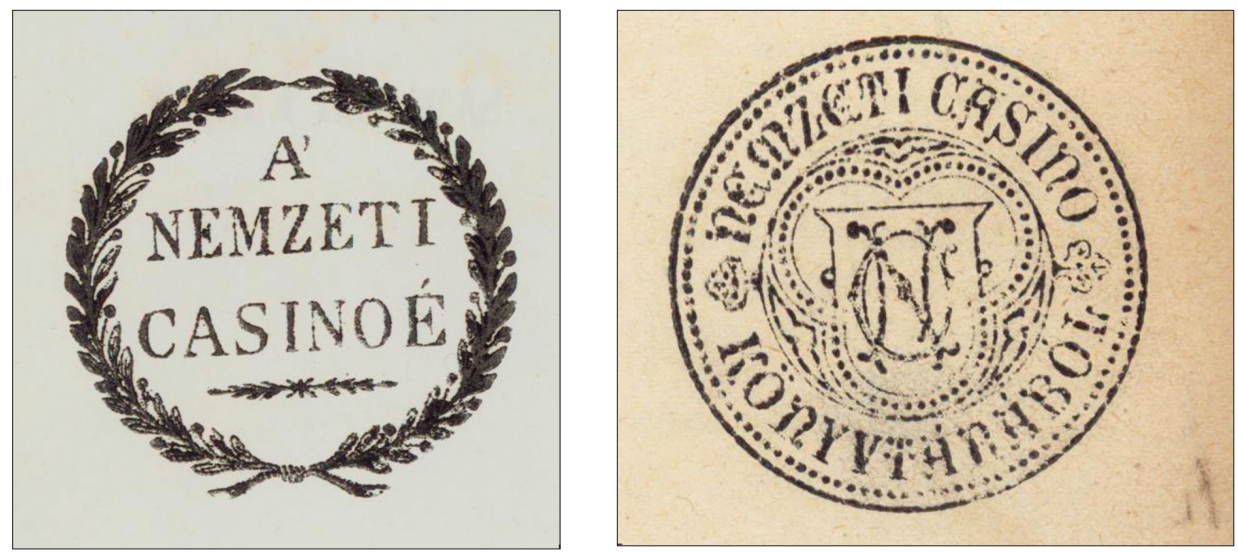

6-7. kép. Az NC két leggyakoribb pecsétje

A kötetek egy része azonos könyvkötő mühelyből került ki, ez kiderül a könyvek végén található szárazpecsétekből, melynek szövege: „Molnár Mihály ezelőtt Bóka L. könyvkötő Budapesten”. 


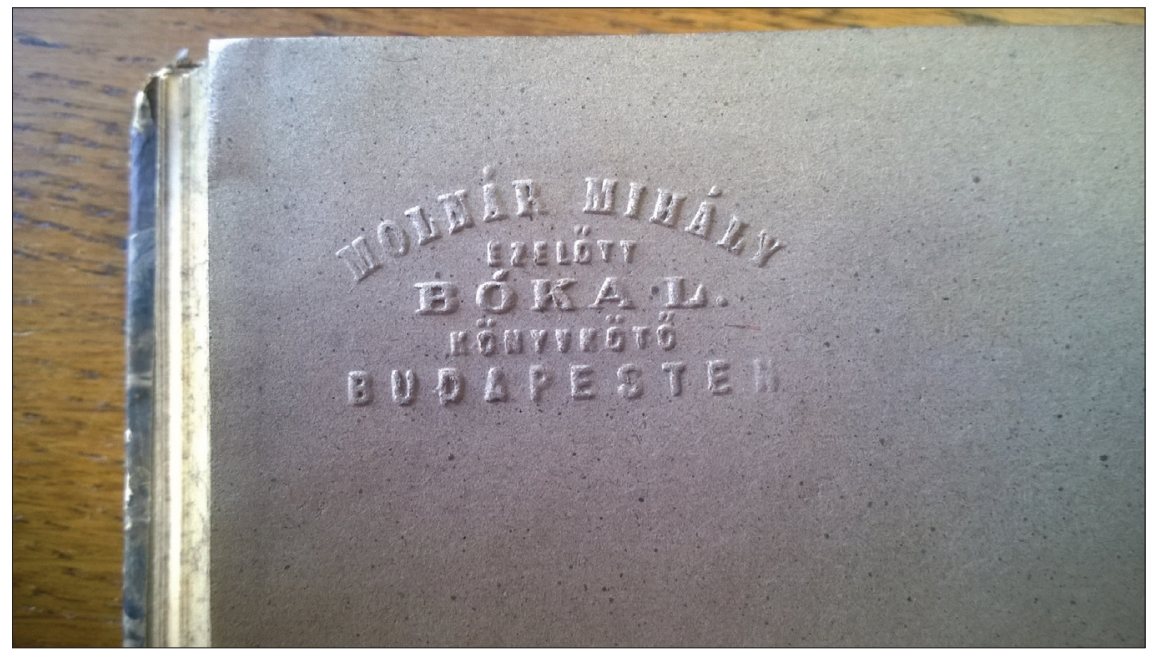

8. kép. A szárazpecsét

A könyvár inventáriumai még lappanganak. A feljegyzések szerint a feloszlatást követő költözéskor a romos épületből elszállították a következőket:22

- 1943-ig vezetett betürendes mutató a könyvtárhoz, 4 kötetben;

- az NC osztálykatalógusai 13 kötetben (két osztály katalógusa már ekkor hiányzott);

- az NC névkönyvei és az Idegenek könyve;

- továbbá más egyéb tárgyak.

Ezeket a katalógusokat még keressük. Az egyéb tárgyak között volt egy 1830as évekből származó földgömb, illetve hét ${ }^{23}$ afrikai és magyar vadásztrófea. 1947. augusztus 1-jén a trófeákat a MTA Könyvtára átengedte örökletétként a Természettudományi Múzeumnak, a „tönkremenés veszélyétől való megóvás végett" ${ }^{24}$ Jelen kutatásunk során felvettük a kapcsolatot a Természettudományi Múzeummal, ahol tájékoztattak minket, hogy sajnálatos módon az 1956-os események során tüz ütött ki az épületükben, így sok mütárgy megsemmisült. A tételes keresés során viszont rátaláltak öt vadásztrófeára, melyek sértetlen állapotban jelenleg is az állományuk részét képezik.

Az NC tulajdonában voltak egyéb mütárgyak is (festmények, térképek, bútorok), ezek hollétéről ma még nincs információ. Minden valószínüség szerint egy részüket vidékre mentették, más részük a romépületben maradhatott, esetleg megsemmisült.

${ }^{22}$ Nyireo János: Pro memoria. 1946. MTA KIK Kézirattár és Régi Könyvek Gyűjteménye. K 829:282/1946.

${ }^{23}$ Egyes iratok 8 trófeát említenek.

${ }^{24}$ Melich János: [Levél az Elnök Urnak]. 1947. 


\section{Nemzeti Casino a Magyar Nemzeti Múzeumban}

A feldolgozás megkezdésével párhuzamosan kezdetét vette az NC történetének és fennmaradt iratainak kutatása is. Hamar előkerült néhány dokumentum, melyekből megtudtuk, hogy az Akadémiai Könyvtár 2001 kötet régi könyvet adott át a Magyar Nemzeti Múzeumnak 1991 augusztusában, egy Széchényi-emlékkiállítás céljára. A könyvek kiválasztásánál a múvek kötése és állapota játszott szerepet. A könyvek azóta is a Múzeum Széchényi-termében vannak kiállítva. (Széchényi Ferenc emlékére készült a kiállítás és a terem, ennek a részét képezi a fia hagyatéka.)

2015 kezdetén megtörtént ennek az állományrésznek a számbavétele is. A külön kezelt könyvek a folyóiratok megoszlásának számaránya 50-50\%.

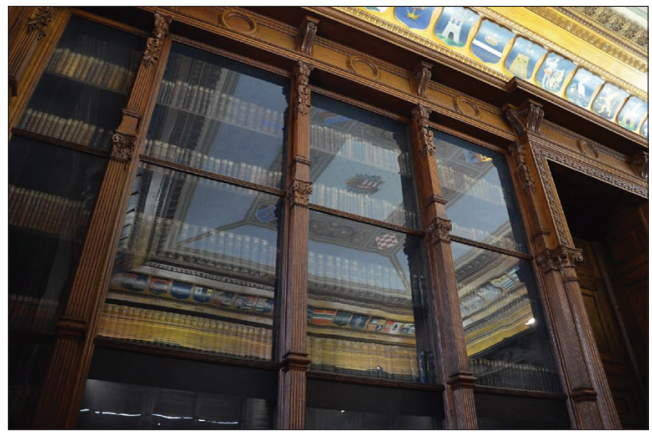

9. kép. A MNM Széchényi-terme

\section{További teendők}

Az utolsó állományadatok szerint a gyüjtemény 30.000-40.000 kötetből állt. Ebből jelenleg 20.000 nyomtatványt ismerünk. A hiányzó rész vagy háborús bombatalálatok következtében semmisült meg, vagy hollétéről ma még nincs adatunk, például magánszemélyekhez kerülhetett. Ezzel magyarázható például, hogy az utóbbi években egy-egy kötet felbukkant néhány antikvárium kínálatában.

Előzetes becslés szerint feldolgozásra vár még mintegy 6.000 kötet. A teljes állomány tényleges katalogizálási folyamata várhatóan két év alatt fejeződik be. A folyóiratok előzetes számbavétele már megtörtént, a továbbiakban szükséges az adatok pontosítása, kiegészítése, és összevetésük a törzsgyüjteményi állománnyal. Az állomány eddig feltárt történetéből látható, hogy milyen mértékben sérültek a dokumentumok, s közülük jelentős rész restaurálásra szorul.

A feldolgozás után kezdetét veheti a Nemzeti Casino könyveinek statisztikai áttekintése, mely átfogó képet adhat az állomány pontos összetételéről. Az egyesület történetének további kutatása még várat magára, emellett újabb hiánypótló információk remélhetők a vidéki és erdélyi kaszinók müködésének megismeréséből.

A nagyközönségnek egy kiállítással tervezi a könyvtár bemutatni a Casino történetét, örökségét, ritkaságait és különlegességeit. 


\section{Rezümé}

A Nemzeti Casino egyesületet Széchenyi István alapította 1827-ben. Közel 120 éves fennállása során szerves részét képezte a magyar közéletnek és kultúrának. Tervszerủen gyarapított és rendszerezett könyvtára kiemelkedett az ország közkönyvtárai közül, mind tartalmi, mind mennyiségi szempontból. A magyar belügyminiszter egy 1945-ös rendeletével feloszlatta a Nemzeti Casino-t, mint az ország érdekeivel ellentétes múködést kifejtő jogi személyt. Az egyesület alapszabályának értelmében feloszlatása esetén összes vagyonát a Magyar Tudományos Akadémia örökli. Ennek értelmében a Nemzeti Casino könyvtára jelenleg az MTA Könyvtár és Információs Központ gyűjteményének részét képezi. A közel 20.000 könyv feldolgozása sokáig váratott magára, a munka befejezése elött viszont még nem lehet pontos számadatokkal szolgálni. 2015 végéig az állomány körülbelül fele került be az elektronikus katalógusba MARC21 formátumban.

\section{National Casino}

The National Casino Association was founded in 1827 by István Széchenyi. For the nearly 120 years of its existence it was an integral part of the Hungarian public life and culture. The methodically collected and systematized library rose above the country's public libraries qualitatively and quantitatively as well. The Minister of the Interior of Hungary dissolved the National Casino with a decree in 1945 claiming it to be a legal person with an activity against the interests of the country. The association's statutes provide that the Hungarian Academy of Sciences inherits all the assets of the Casino in case of dissolution. Therefore now the library of the National Casino is a collection of the Library and Information Centre of the Hungarian Academy of Sciences. Much time elapsed before the entering the ca. 20.000 books in the calalogue had started, and before the end of the work we don't even know the exact number of the documents. Until the end of 2015 about half of the collection has been introduced into the Aleph electronic catalogue in MARC21 format.

GYURICZA ANDREA

fiatal kutató

MTA Könyvtár és Információs Központ 

KOMPLEX ADATBÁZIS-KERESŐK 



\section{Könyvtárak - belépési pontok a digitális világba}

Az új típusú keresőrendszerek megjelenését a változó környezet, a változó keresési szokások indokolták. Megértéséhez tekintsük át digitális világunkat és ebben a könyvtárak új szerepét!

\section{A digitális világ, a digitális nemzedék}

A következők az egész világon érvényes megállapítások, de most elsősorban Magyarországot nézem az internethasználat és a digitális tartalmak fogyasztása tekintetében. Az internethasználat folyamatosan nő, Magyarországon 2016 júniusában több mint 5 millió fö használta a hálózatot a 15 évnél idősebbek körében. Ez megfelel az európai átlagnak, és magasnak mondható a kelet-közép-európai régióban. Nagy részük $(76,6 \%)$ napi szinten fogyaszt digitális tartalmat. A netezők 69\%-a a 18-49 év közötti korosztályból kerül ki, de a 60 éves kor feletti felhasználók aránya is folyamatosan emelkedik. ${ }^{1} \mathrm{Az}$ internethasználat egyre inkább a mobil eszközökre tevődik át: mobiltelefont, okostelefont, laptopot, táblagépet (tabletet) használunk. Ezek az eszközök mindig kéznél vannak, így folyamatosan információhoz jutunk és információt továbbítunk, miközben a mobilinternet használatával folyamatos az internetkapcsolat.

A fiatalok munkavégzéssel kapcsolatos elvárásai nem ugyanazok, mint a korábbi korosztályoké, amit a munkaadóknak is figyelembe kell venni. Míg évekkel ezelött konferenciákon és tanulmányokban is éles viták voltak arról, mennyire biztonságos a céges környezetben a mobil eszközök használata, addig ma ez már elfogadott. A Cisco 2013-as felmérése szerint (mely nem volt reprezentatív) a hazai munkavállalóknak már $60 \%$-a rendelkezett olyan mobil eszközzel, mellyel képes volt csatlakozni a munkahelyi hálózathoz, és el tudta érni a céges adatokat, alkalmazásokat. ${ }^{2}$ Emellett változik az olvasási, információszerzési kultúra is, amit jól szemléltet az alábbi két, korunkra ható írástudótól származó idézet: „... a könyv az emlékezet és a képzelet meghosszabbítása” (Jorge Luis Borges, aki 1955-1973 között az Argentin Nemzeti Könyvtár igazgatója volt). „Keveredik az olvasás és az információszerzés” (Esterházy Péter).

A fiatalok nemcsak a munkavégzéssel kapcsolatban gondolkodnak másképp, hanem másképp jutnak információhoz is. A lexikonok, könyvek helyett az

${ }^{1}$ Gyorsjelentés a hazai-internetezőkröl. Forrás: Q2 gyorsjelentés a hazai internetezőkről. Gemius, 2016. augusztus 4. Forrás: http://hirlevel.egov.hu/2016/08/07/gyorsjelentes-a-hazai-internetezokrol (2016. augusztus 4.)

${ }^{2}$ A munkahelyeken is terjed a mobil eszközök használata. Forrás: https:/itcafe.hu/hir/cisco mobil_eszkozok_byod_felmeres.html (2016. augusztus 4.) 
internet használatát előnyben részesítő „,internetfüggő” diák nyilvánvaló konfliktusforrás a „maradi” oktatási rendszerben. Az ,internetfüggést” nem rossz értelemben használom, hiszen mennyivel egyszerübb az úgyis kézben lévő mobil eszköz keresőjébe (Google, Wikipédia) beírni azt, ami érdekel, amiről többet szeretnénk tudni, és pillanatokon belül megkapjuk a választ - valljuk be, nekünk is, akik nem az internet világában szocializálódtunk. És másképp is kommunikálnak ,... az a természetes, hogy egymás mellett ülünk, szakmai kérdésekről beszélgetünk, és a másik nem csak hozzászól a vitához, hanem gyorsan küld egy grafikont, ami alátámasztja, vagy éppen cáfolja, amit mondtam". ${ }^{3}$

A szakirodalom a digitális készségek alapján csoportokat alakított ki, melyek a születési dátumot figyelembe véve határozzák meg kinek milyen a viszonya a digitális világgal. ${ }^{4}$ Ez alapján az 1925-1945 között született generáció alkotja az építők vagy a veteránok csoportját, az 1946-1964 között születettek a Baby boom nemzedéket, az X generációhoz az 1965-1979 között született korosztályt sorolják. Az Y generációt az 1980-1995 között született korosztály, a Z generációt az 1996-2009 között született korcsoport (ők a digitális bennszülöttek) alkotja. Az alfa generáció a 2010 után született nemzedék, ők azok, akik most kerülnek iskolás korba.

A világháló hatalmas információs tudásbázisában nehéz eligazodni, „... miközben a legtöbb website tökéletesen ismeretlen, van néhány olyan centrum, mint a Google, az Amazon vagy a Yahoo!, amely linkek millióit gyüjti egybe". ${ }^{5}$ Sokszor nem egyszerü felismerni a hiteles forrásokat, meg kell tanulni jól keresni a rendelkezésünkre álló információhalmazban, jól használni és továbbadni a szerzett tudást. Nekünk, akik nem beleszülettünk az internethasználatba, és több a korábbi, nem interneten szerzett tudásunk, talán egyszerübben szelektálunk a világhálón megjelenő tartalmak között. Tudjuk, hogy nem minden információ származik hiteles forrásból - az egyének mellett a könyvtáraknak is felelösségük van az Y, a Z és az alfa generációk „okosításában”. A digitális nemzedék nem érti, miért tiltják az oktatók a Wikipédia használatát. Szerintük, ahogy bárki készíthet weboldalt, online újságot, a Wikipédiához is bárki hozzáadhat újabb információt, hiszen ez is egy közösségi forrás. Azt hiszik, hogy a Google keresés találatai közül az elsők a legnépszerübbek és egyúttal a legmegbízhatóbbak is. „A legfontosabb azonban, hogy ne hagyd abba a kérdezést. A kíváncsiság nem véletlenül van a világon." - Einstein híres mondása az internet világában is érvényes és időszerü, hangsúlyozása talán valamennyi fent megfogalmazott kritikai észrevételnél fontosabb. Ennek szellemében, ha az idősebb korosztály szót

$3 \mathrm{Az}$ információ hatalom, mégsem használjuk. Forrás: http:/hvg.hu/vallalat_vezeto/ 20160804_digitalizacio_hatekonysagnoveles (2016. augusztus 4.)

${ }^{4}$ Generációs elméletek. Forrás: http://janus.ttk.pte.hu/tamop/tananyagok/digitalis_nemzedek/ genercis_elmletek.html (2016. augusztus 4.)

${ }^{5}$ Barabási Albert-László: Villanások. A jövő kiszámítható. Budapest, Nyitott Könyvmühely, $2010.335 \mathrm{p}$. 
akar érteni a digitális bennszülöttekkel, akkor a „digitális bennszülöttek nyelvén és igényeik szerint kell megfogalmazni és kifejezni azokat az ismereteket, információkat, amiket szeretnénk megosztani" ${ }^{6}$ velük.

Változnak a keresési szokások, Barabási-Albert László szerint „Manapság villanásos keresési eljárásokkal" keresünk. Kutatások, elemzések vizsgálják a keresési szokásokat, a „,.. tudósok bebizonyítják, hogy egy adott tárgy megtalálására nem a kézenfekvő szisztematikus keresés, hanem egy kicsúcsosodó, megszakításokkal, sőt esetlegességgel operáló stratégia a leghatékonyabb".?

\section{Könyvtárak új szerepe - digitális könyvtár}

Nézzük meg mi a digitális világban a könyvtárak új szerepe, hogy válik a könyvtár digitális könyvtárrá! Az internet terjedése és a digitális nemzedék fentiekben érintett hatásain kívül nagy szerepe van a technológiai fejlődésnek abban, hogy változnak a könyvtárakkal szembeni elvárások. A technológiai fejlődés olyan gyors, hogy ma még elképzelni sem tudjuk, milyen eszközöket fogunk használni pár év múlva. A mobil eszközök, a szoftverek fejlesztése, a nanotechnológia hihetetlen távlatokat ígér. 1959-ben Richard Feynman fizikus még csak elmélkedett a nagyon kicsi gépekről, ma már kísérleteznek nanobotokkal (nanométer hosszúságú robotok), melyek az emberi testben keringve folyamatosan kommunikálni tudnak az okoseszközökkel. ${ }^{8} \mathrm{Az}$ új fejlesztések, az új eszközök már a könyvtárakban is megjelentek, rendelkezésre állnak, és segítik a kutatók munkáját. Ilyen például a fordítóceruza vagy a digitális szövegkiemelő, míg a szabad polcon elhelyezett könyvek közötti eligazodást segítheti a digitális könyvjelző. Ismerjük már a drónokat, lehet kísérletezni könyvtári alkalmazással, például drónt használni könyvek kiszállítására. ${ }^{9}$ Alkalmazzák már az igény szerinti nyomtatást: könyvesboltok is kínálnak ilyen szolgáltatást, de könyvtárban a könyvtári állományból is előállíthatunk digitális másolatot a szerzői jogi szabályozás betartásával. Egyelöre ez utóbbi szolgáltatás iránt korlátozott a fizetőképes kereslet, ezért kevéssé tekinthetők sikeresnek az ilyen irányú próbálkozások. A könyvtár további szolgáltatásokat kínálhat speciális mobil applikációk segítségével, ilyen például az az olvasó alkalmazás, amivel hozzáférhetünk a MEK könyveihez, vagy az e-könyv kölcsönzés kezelése, figyelmeztetés a kölcsönzött könyv lejáratára, az elektronikus források elérése a könyvtári kártya alapján, a könyvtári katalógus mobil eszközökre való adaptálása stb. A könyvtárnak - alkalmazkodva a megváltozott használói szokásokhoz - mind az egyéni, mind a közösségi igények kiszolgálá-

${ }^{6}$ Digitális bennszülött és digitális bevándorló. Forrás: http://janus.ttk.pte.hu/tamop/tananyagok/digitalis_nemzedek/digitlis_bennszltt_s_digitlis_bevndorl.html (2016. augusztus 4.)

${ }^{7}$ Barabási Albert-László: I. m.: 179. p.

${ }^{8}$ Szauer Tamás: Nanobotok és az örök élet. HVG, 38. évf. 2016. 35. sz. augusztus 25. 62. p.

${ }^{9}$ Piotr Kowalczyk: Library of the future. 8 technologies we would love to see. Forrás: http:// ebookfriendly.com/library-future-technologies/ (2016. augusztus 4.) 
sára alkalmasnak kell lenniük: közösségi tereket, kiscsoportos tanuláshoz alkalmas, online foglalással igénybe vehető szeparált helyiségeket egyaránt kell biztosítaniuk. Mivel a tanulás, a kutatás, a munkavégzés már nincs helyhez kötve, egyre népszerübbek a távolról elérhető szolgáltatások (például az elektronikus tartalmakhoz való távoli hozzáférés), ezekkel párhuzamosan a hagyományos funkciók (könyvkölcsönzés, másolatok kérése stb.) egyre inkább háttérbe szorulnak.

$\mathrm{Az} Y$ és a $\mathrm{Z}$ generáció tagjai részben már most jelen vannak a munkaerőpiacon, ezért a könyvtári szolgáltatások tervezésekor pontosan ismerni kell az igényeiket. Választ kell kapnunk arra,

- hogy és hol tanulnak,

- hogy és hol dolgoznak,

- hogy és hol szereznek információt,

- hogy és hol hasznosítják a megszerzett információt.

Az Y és a $\mathrm{Z}$ generáció számára mások a prioritások, mint a korábbi generációk számára. Mobilak, nem helyhez kötöttek, bárhol tudnak tanulni, kutatni, dolgozni (kávézóban is, ha van internet, ha pedig nincs, használja saját mobilinternetét, akár külföldröl is), nincsenek egész nap a munkahelyen. Ma már olyan cégek is vannak, ahol a dolgozónak asztala sincs, mindenki oda ül, ahol hely van, illetve ahogy a projekt szerinti csapatmunka megkívánja. Érdemes elolvasni a Z-generáció álommunkahelyéről szóló, nemrég megjelent cikket a HVG weboldalán. ${ }^{10} \mathrm{~A}$ cikkben megfogalmazott munkakörnyezet biztosítása valószínúleg nem elsősorban a könyvtárakban jelenik meg, de érdemes készülni rá.

Megváltozott a kutatási, tanulási folyamat. A nyomtatott világában a könyvtár a tanulás, kutatás fontos helye volt, a könyvtárban elérhető dokumentumokból dolgoztak, szereztek új információt a kutatók, a könyvtár köré szervezték a feladataikat, munkafolyamataikat, a könyvtár korlátozottan volt kapcsolatban a teljes folyamattal. A digitális világban ez megváltozott. A könyvtárnak kell alkalmazkodnia a kutatók és tanulók munkafolyamataihoz. A munkafolyamatok információs forrásokat generálnak és használnak. A világháló hozzájárul a tudomány zárt struktúráinak nyitottabbá tételéhez. Beszélünk már open access folyóiratokról, nyitott tudományról (open science), nyílt forráskódú (open source) programokról. ${ }^{11} \mathrm{~A}$ könyvtár már nem az egyedüli hely, ahol információhoz juthatunk. Az információszerzés szükségessége nem korlátozódik a tanulás időszakára, illetve a munkában töltött évekre. Az egész életünk során tanulunk, ebben a gyorsan változó világban az „érvényes tudás” felezési ideje jelentős mértékben csökkent, szükség is van az ismeretterületek közti mobilitásra. Az információszerzésre kitágult a tér: az internet otthonról, a könyvtárakból és az egyéb közösségi helyekről is elérhető.

${ }^{10}$ Ilyen a Z-generáció álommunkahelye. Forrás: http://hvg.hu/brandchannel/HVG_konferencia_20160825_Ilyen_a_Zgeneracio_alommunkahelye (2016. augusztus 4.)

${ }^{11}$ Nyíri Kristóf: Nyitott tudomány, nyitott oktatás. Forrás: http://www.hunfi.hu/nyiri/OKTK 2000.htm (2016. augusztus 4.) 
A kutatás és a tanulás munkafolyamatainak megfelelően célszerủ átalakítani a szolgáltatásokat és új információforrásokat beszerezni. A folyamatok során a kutatók felhasználnak és létre is hoznak információforrásokat. A könyvtárak infrastruktúrát, elérhető forrásokat, online szolgáltatásokat biztosítanak, elektronikus forrásaikat repozitóriumokban archiválják. A könyvtári katalógus a dokumentumok bibliográfiai (meta)adatait tartalmazza, melyek már az online katalógusban is kapcsolódtak másik bibliográfiai vagy authority adathoz, a digitalizált dokumentum a nyomtatott leírásához. Az authority adatok tartalmaznak névváltozatokat, írói álneveket, vagyis utalásokat a besorolási elemhez, tartalmazhatnak linket különböző névterekhez (MTA AAT, VIAF, MTMT stb. adatbázisokhoz). A digitális világban a strukturált adatok kapcsolódásainak kezelése a szabványos web technológiákon alapszik, ez a szemantikus kereséshez elengedhetetlen. A jövőben ennek egyre nagyobb szerepe lesz, hiszen nem a katalógus készítőjének kell megadni a kapcsolódásokat, hanem a helyesen bevitt adatok alapján a web technológia révén automatikusan létrejön a kapcsolat. ${ }^{12}$ A pontosságnak, az adatok helyességének éppen ezért még fontosabb jelentősége lesz a feldolgozásban. Tekintettel az új könyvtári szerepre, érdemes átgondolni és mélyíteni a könyvtárak közötti együttműködést, hiszen a kapcsolt adatok karbantartása is gazdaságosabb, ha a könyvtárak együttmüködésén alapszik.

Célszerü a könyvtáraknak is jelen lenniük a közösségi hálón, mivel az internethasználók számára ez a kommunikáció egyik fontos eszköze. A könyvtári világot (a könyvtárban felhalmozódott tudást, az adatokat) az egész webes világ (World Wide Web) részévé kell tenni!

\section{Új keresési, kutatási (discovery) szolgáltatások}

A könyvtári szolgáltatások fejlődésének első állomása az integrált könyvtári rendszerek megjelenése volt, már több mint 30 éve hogy piacra kerültek az első szoftverek. Ahogy változtak a keresési szokások, úgy indult el a fejlesztés a metakereső rendszerek irányába, később ezekhez a rendszerekhez linkfeloldó szolgáltatásokat is fejlesztettek. Ez lehetővé teszi a kereséskor talált dokumentum teljes szövegü elérését, ha az releváns. A linkfeloldó a tudásbázis alapján ellenőrzi, hogy a könyvtár melyik szolgáltatóval áll kapcsolatban, és hogy ott az adott dokumentum elérhető-e: ezen információk szerint kapcsol a szolgáltatói oldalra. A következő fejlődési állomás a discovery rendszerek megjelenése volt. Az új keresési elvárásoknak megfelelően a felfedező keresés, a könyvtári források egy időben való keresése került előtérbe. A discovery rendszer esetében mindenképpen célszerủ a korábbi OPAC kiváltása, mivel minden OPAC funkció integrálva van bennük, kapcsolódnak az integrált könyvtári rendszerhez.

${ }^{12}$ Axel Kaschte: Linked open data on its way into next generation library management and discovery solutions Forrás: http://leo.cineca.it/index.php/jlis/article/view/5492 (2016. augusztus 4.) 
A discovery (egységes magyar elnevezést még nem sikerült találni, de pl. a Budapesti Corvinus Egyetem Egyetemi Könyvtár „Szuperkereső”-nek nevezi) szolgáltatások jellemzői:

a) a felfedező keresés (discovery): használóközpontú keresés, a kutatóra bízzuk, mit és hogy akar keresni;

b) az egyablakos keresés, s mellette lehetőség van a gyakorlottak számára több szempont szerinti keresésre is;

c) a könyvtár minden forrásában egyszerre lehet keresni, ugyanakkor lehetőség van speciális keresésre (például adott szerző adott mủvére keresni, vagy kizárólag a kölcsönözhető állományra korlátozni a keresést) a kiválasztott katalógusban, adatbázisban;

d) a teljes szövegü tartalmak elérése az intézmény által előfizetett adatbázisokban, intézményi repozitóriumokban;

e) a kapcsolt adatok: új technológia megjelenése.

A felfedező keresés használóközpontú, elsősorban a témára való keresésnél élvezhetjük az előnyeit. Ha azonban nem korlátozzuk a keresést egy adott forrásra, akkor olyan információk is elérhetők lesznek, melyek az addig még nem ismert adatbázisokban érhetők el. Fontos elv, hogy a könyvtárnak mindent fel kell kínálnia, ami elérhetö, és majd a használó válogat - hiszen ő tudja, mire van szüksége. A discovery szolgáltatás ugyanakkor azt is lehetővé teszi, hogy a keresés során újabb és újabb, számára értékes információt fedezzen fel. Az egyablakos keresésnél az egyszerre kereshető források a könyvtári konfigurálástól függenek. Kialakítható rádiógombokkal vagy lenyitható menüben való választással, hogy milyen forrásban kereshetünk. Az adott könyvtár használóinak szokása szerint érdemes meghatározni az egyszerre, egy időben kereshető adatbázisok csoportját. Néhány lehetséges példa: Könyvtári állomány nyomtatott és elektronikus Elöfizetett, licencelt elektronikus - Hozzáférhetö - Minden együtt - Folyóiratok csak nyomtatott, vagy nyomtatott és elektronikus együtt - E-könyvek - Olvasó központú beszerzéssel (PDA) elérhető gyüjtemény(ek) - Osztott források stb. A teljes szövegü tartalmak elérhetők a találati halmazból, a rendszer mögötti tudásbázis alapján a releváns szolgáltatónál. A távoli elérést a szolgáltatók sokszor egyéni bejelentkezéshez kötik, az egyetemek belső hálózati elérésként teszik lehetővé az egyetemi polgárok (hallgatóik, oktatóik) számára a használatot.

A discovery rendszer elemei:

a) a felhasználói felület, mely többé-kevésbé testreszabható;

b) a linkfeloldó, mely a teljes szövegü elérést biztosítja;

c) a közös index, ami lehetővé teszi az elérhető források egy időben történő keresését, így a keresés gyorsabb, a különböző forrásokból származó tételek megjelenítése egységes felületen, egységes adatokkal történik; 
d) a könyvtári online katalógus elérése, ami lehetővé teszi a meglévő példányok ellenőrzését, előjegyzését, a kölcsönzés lejáratának kontrollálását stb. (bizonyos szolgáltatások csak a bejelentkezett használók számára biztosítottak);

e) API-kon keresztül külső források, egyéb szolgáltatások érhetők el. A közös index létrehozásának vannak korlátai: az egyes források szolgáltatói engedhetik vagy éppen tilthatják a közös rendszerbe való indexelést. A közös indexben a kiadóktól és a szabad hozzáférésü és intézményi repozitóriumokból származó metaadatok és a teljes szöveg elérhetősége, az Abstracting and Indexing (A\&I) források adatai, valamint a könyvtári menedzsment rendszerből a bibliográfiai és példányadatok találhatók. Amennyiben nincs lehetőség a tényleges közös index létrehozására, a virtuális közös index a megoldás: ebben az esetben is tudjuk a különböző forrásokat egyszerre keresni és egy találati halmazban megjeleníteni, azonban ilyenkor a keresés kicsit tovább tart.

A piacon elérhető nyílt hozzáférésű programokon alapuló, illetve kereskedelmi forgalomban kapható discovery rendszer is. ${ }^{13}$ Kereskedelmi forgalomban kapható a Primo és a Primo Central Index (ExLibris) ${ }^{14}$, az Ebsco Discovery Service (Ebsco EDS) ${ }^{15}$, a Summon (ProQuest) ${ }^{16}$ és a WorldCat (OCLC). Nyílt forráskódú programon alapul a VuFind. ${ }^{17}$ Ezekben az alkalmazott technikák a szabványokat vagy ajánlásokat követik, így biztosított a fejlesztésük, a technológiai változások követése. ${ }^{18} \mathrm{Az}$ indexek aktualizálása OAI-PMH alkalmazásával vagy batch feltöltéssel történik. A kereső platformhoz a nyílt forráskódú Apache Solr, a weboldal kialakításhoz PHP programozási nyelvet, a találatok rangsorolására relevancia rangsorolást használnak. Az egyes rendszereknél különböző relevancia rangsorolásokat dolgoztak ki. Ezeket a használó általában nem állíthatja át, a rendszerek implementálásánál kerül meghatározásra, hogy a bonyolult algoritmusban milyen mezők, paraméterek játszanak szerepet. Az adatcserét szabványos protokollal végzik, az adatkapcsolatokat automatikusan építi fel a rendszer. Kapcsolt adatként jelenik meg például a találati listában a könyvborító, amit a Google Books szolgáltatás biztosít a Google Könyvek adatbázisából ISBN alap-

${ }^{13}$ Discovering What Works: Librarians Compare Discovery Interface Experiences Forrás: http://reviews.libraryjournal.com/2011/12/reference/discovering-what-works-librarians-comparediscovery-interface-experiences/ (2016. augusztus 4.)

${ }^{14}$ Ismertetés: http://www.exlibrisgroup.com/category/PrimoCentral (2016. augusztus 4.)

${ }^{15}$ Ismertetés: https://www.ebscohost.com/discovery (2016. augusztus 4.)

${ }^{16}$ Ismertetés: http://www.proquest.com/products-services/The-Summon-Service.html (2016. augusztus 4.)

${ }^{17}$ Ismertetés: http://vufind-org.github.io/vufind (2016. augusztus 4.)

${ }^{18}$ NISO Open Discovery Initiative. Forrás: http://www.niso.org/apps/group_public/download.php/14487/future_library_resource_discovery.pdf); NISO RP-19-2014, Open Discovery Initiative: Promoting Transparency in Discovery http://www.niso.org/apps/group_public/download. php/14820/rp-19-2014_ODI.pdf (2016. augusztus 4.) 
ján. Hasznos szolgáltatás a szerzők adatainak elérése is a különböző névterekben, hiszen így a használó a keresése kapcsán további információkhoz jut.

Az eddigiek alapján látjuk, miért fontos a felfedező keresés, miért indultak el a fejlesztők ebbe az irányba. Az információhoz jutás a tanulás alapja, s az új keresési szokások a tanulási folyamatra építenek. Az induló keresés a témával kapcsolatos irodalom felfedezését teszi lehetővé. Innen továbblépve, beleolvasva a metaadatokba, vagy a teljes szövegủ tartalomba, további információhoz jutunk, ötleteket kapunk a további kereséshez. Utána már szisztematikusan kezdünk kutatni az új ismeretek, kulcsszavak felhasználásával. Ha egy konkrét, ismert információ (például a dokumentum címe) alapján keresünk, nem szükséges a minden forrásban történő keresés, célszerü ekkor az adott keresőcsoportot (könyvtár gyüijteménye, cikk keresése stb.) kiválasztani. A témára keresés már indokolja a mindenben keresés választását, hiszen sokkal nagyobb a merítés, felkínáljuk a kutatónak az összes elérhető forrásunkat, és rábízzuk, hogy ő szelektáljon és válassza ki a számára releváns irodalmat.

A könyvtárak számára új úgy alkalmazkodni a használók igényeihez, hogy nem kiszolgálják, hanem segítik a hallgatókat, kutatókat a leghatékonyabb információhoz jutásban. Ennek megfelelően alakítják a szolgáltatásokat, felkínálják a könyvtárban elérhetö összes forrást oly módon, hogy a használók gyorsan és könnyen jussanak a számukra releváns információhoz.

\section{Rezümé}

Az új típusú keresőrendszerek megjelenését a változó környezet, a változó keresési szokások indokolják. Az internethasználat folyamatosan nő: Magyarországon az európai átlagnak megfelelő, sőt a kelet-közép-európai régióban magasnak mondható, napi szintü a digitális tartalmak fogyasztása. A digitális nemzedék másképp gondolkodik a munkavégzéssel kapcsolatban, mások a prioritások, és másképp is kommunikál. A könyvtáraknak figyelembe kell venniük a digitális nemzedék igényeit, keresési szokásait. Az új típusú discovery (felfedező) szolgáltatások egységes felületen kínálják az elérhető forrásokat, a tanulás a felfedező keresés egyik fontos eleme. Témára keresésnél az online katalóguson kívül az intézményi repozitóriumból és az előfizetett forrásokból egyszerre kapjuk meg a releváns találatokat. A jelenleg használatban lévő discovery rendszerek a Primo, az EBSCO EDS, a Summon, az OCLC WorldCat és a VuFind. A könyvtárnak alkalmazkodni kell a használói igényekhez, nem kiszolgálni, hanem segíteni kell őket a leghatékonyabb információhoz jutásban.

\section{Libraries - Entry Points to the Digital World}

Academic libraries are no longer the only choice for students and researchers to go for information. In the digital world blogs and wikis, Facebook and YouTube create new 
types of content. The digital natives have different needs, they search, learn, work and communicate in a different way. As the search behaviors changed, discovering became the new trend. The discovery systems make accessible all the materials that a library can offer (print and electronic) through a single search box. Libraries have to give up some traditional catalogue functionalities and offer a unified view of all institutional data whether it comes from the online catalogue or the institutional repository or a licensed resource. Libraries have to know what topics users are searching and how they search and have to introduce new services based on the new trends.

NASZÁDOS EDIT

szakmai tanácsadó

MTA Könyvtár és Információs Központ 



\section{A Szuperkereső felemelkedése EDS a Corvinuson}

\section{A kialakítás folyamata}

A Budapesti Corvinus Egyetem (BCE) Egyetemi Könyvtára 2013-ban döntött úgy, hogy előkészíti és bevezeti szolgáltatásai körébe az úgynevezett discovery, azaz közöskereső-szolgáltatást, mely egy felületen teszi kereshetővé a könyvtárban hozzáférhető tudományos adatbázisokat, elektronikus folyóiratokat és a könyvtári katalógust.

A közös kereső bevezetése mellett több érv is szólt. Egyfelöl a discoverytípusú szolgáltatások manapság egyre nagyobb népszerüségnek örvendenek, fontos elemét képezve a legfrissebb könyvtári trendeknek, és ezáltal egyre elterjedtebbek is - így tehát ha egy könyvtár szeretne lépést tartani az informatikai környezet gyorsan változó világával, akkor mindenképpen ajánlott felmérnie a szolgáltatások fejlesztési lehetőségeit e tendenciák mentén. Másfelől a közöskereső-szolgáltatások által nyújtott lehetőségek (pl. egyszerübb keresési felület, gyorsabb hozzáférés a forrásokhoz) nagyban egybevágnak a könyvtár legnépesebb felhasználói körének, az egyetemi hallgatóknak az igényeivel, mely szerint a könyvtári források legyenek minél egyszerübben hozzáférhetők, minél könynyebben kereshetők. A különböző discovery termékeket kínáló szolgáltatók közül a könyvtár az EBSCO terméke, az EBSCO Discovery Service (EDS) bevezetése mellett döntött, mert keresőfelülete, illetve az általa nyújtott egyéb szolgáltatások már megszokottak voltak felhasználóink számára, köszönhetően a könyvtárban már hosszabb ideje elérhető - és a használati statisztikák alapján igen népszerü EBSCO által kínált szakadatbázisok (pl. Business Source Complete) jelenlétének. Az ebből fakadó, és feltehetően az EDS szolgáltatásaira is vonatkoztatható „otthonosságérzés" nagy előnyt jelent egy új szolgáltatás bevezetésénél.

\section{A szolgáltatás bevezetése}

Az EBSCO-val történt kapcsolatfelvétel, majd a szolgáltatás kereteinek kialakítása után 2014 őszén vált nyilvánosan is elérhetővé a könyvtár honlapján az EBSCO EDS, ekkor még „EDS kereső” néven.

A következö lépés a névváltoztatás volt 2016 tavaszán, mert a tapasztalatok azt mutatták, hogy a felhasználók nehezen értelmezték az „EDS kereső” kifejezést. A könyvtár olyan nevet kívánt adni a szolgáltatásnak, mely elsőre is többet elárul a mögötte rejlö funkciókról, a szolgáltatás lényegéről. A nemzetközi mintákkal összhangban azonban mi is tapasztaltuk, hogy a névkeresés nem egyszerü 
feladat: hogyan legyen az elnevezés egyszerre a használók számára közérthető, rövid és lényegre törö, ugyanakkor szakmai szempontból is megfelelö? Végül egy külföldi példa nyomán a „Szuperkereső” elnevezés használata mellett döntöttünk, amit 2016 áprilisa óta használunk.

\section{Miben keres az EDS?}

Több ponton is a saját igényeink szerint alakíthattuk a közöskereső-szolgáltatást, aminek eredményeképpen az EDS a könyvtár saját forrásaiban, valamint az elöfizetett, illetve ingyenesen elérhető adatbázisokban is keres.

A saját források közül első helyen a könyvtár (a Huntéka rendszerével müködtetett) katalógusa áll, döntésünk értelmében a Szuperkereső segítségével azonban csak könyveket találunk, nyomtatott folyóiratokat és analitikusan feldolgozott könyvrészleteket, időszaki kiadványokban megjelent írásokat nem. A rekordok áttöltése a katalógusból az OAI-PMH (Open Archives Initiative Protocol for Metadata Harvesting) protokoll segítségével automatikusan történik, az RTAC (Real-Time Authority Control) technológiának köszönhetően pedig a könyvek példányadatainál valós idejű információkat jelenítünk meg. Mivel a könyvtári katalógus egyelöre nem tartalmaz angol nyelvü tárgyszavakat, így fontos tudatosítanunk a felhasználókban, hogy a könyvtárban fellelhető idegen nyelvű könyvek idegen nyelvü tárgyszó szerinti keresése a Szuperkeresőn keresztül nem feltétlenül vezet teljes eredményre. A közös kereső segítségével elérhető saját könyvtári források másik nagy körét a könyvtár által épített és müködtetett egyetemi repozitóriumok jelentik: a Corvinus Kutatások repozitórium (mely a Budapesti Corvinus Egyetemen keletkező tudományos munkákat gyüjti), valamint a BCE Doktori disszertációk archívum.

A saját forrásokon kívül az EDS a könyvtár által előfizetett, illetve ingyenesen elérhető adatbázisokban is keres. Ezekben az esetekben szintén saját döntéssel határoztuk meg a szemlézett adatbázisok körét úgy, hogy abban a teljes szövegeket tartalmazók mellett bibliográfiai adatbázisok is szerepeljenek, illetve az előfizetett adatbázisokon kívül ingyenesen elérhetők is legyenek (mellyel kapcsolatban fontos segítség az EDS szolgáltatás részeként az új adatbázisokról havonta kapott értesítő). Az új adatbázisok bekapcsolása a könyvtár saját EDSkeresőjébe eleinte automatikusan történt, válogatás nélkül. Rövid idő eltelte után azonban áttértünk a kézi hozzáadásra, ezzel küszöbölve ki a szakterületileg kevésbé releváns források szerepeltetését.

\section{Használati statisztikák}

A szolgáltatás bevezetése, azaz 2014 szeptembere óta a használati statisztikák egyenletesen növekvő tendenciát mutatnak mind a felkeresések, vagyis a keresőoldalon tett látogatások száma (1. ábra), mind a keresések száma tekintetében (2. ábra). Megfigyelhetö, hogy 2016 elején indult el a használatban a markánsabb növekedés, és 2016 áprilisában láthatunk az ábrákon egy nagyobb kiugrást, ami 
feltehetőleg az új elnevezés, a Szuperkereső bevezetésének, illetve az ezt kísérő népszerüsítő kampánynak köszönhető. Látványosan tükröződnek a felkeresések számának alakulását bemutató ábrán (1. ábra) az egyetemi tanév egyes periódusai: érthető módon a nyári hónapokban, illetve a vizsgaidőszakok idején kicsit visszaesik a használat, míg a szorgalmi időszakokban újabb növekedéseket láthatunk.

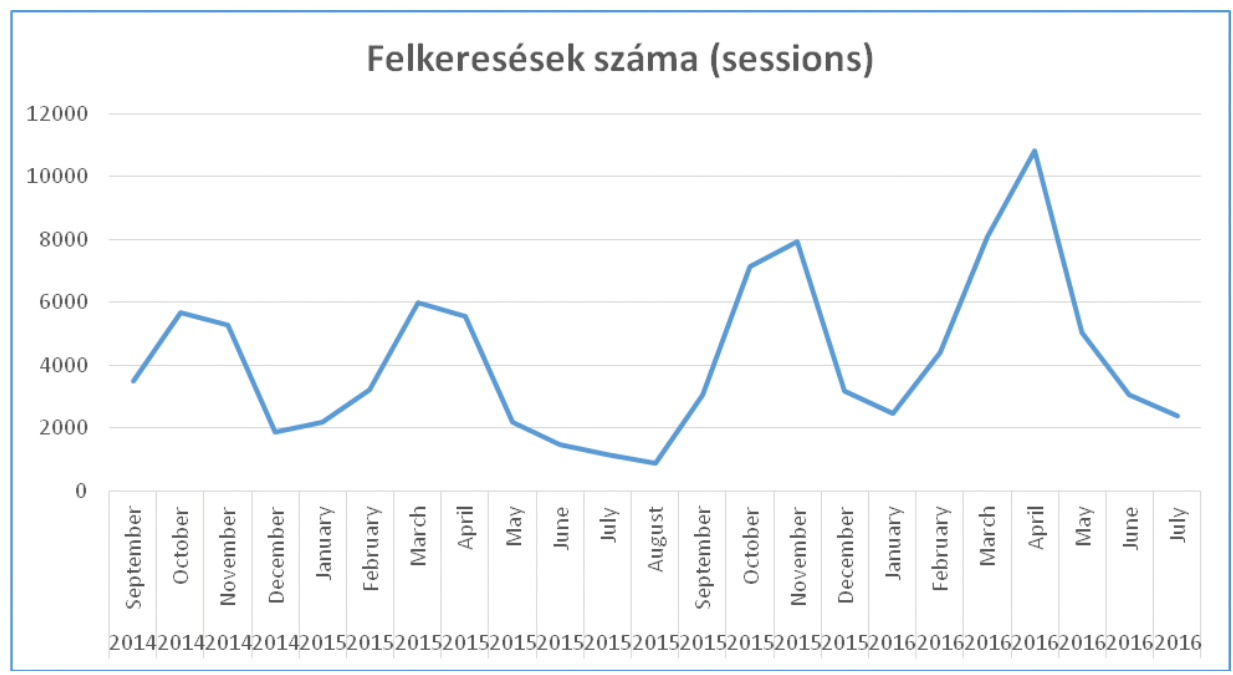

1. ábra. Felkeresések száma

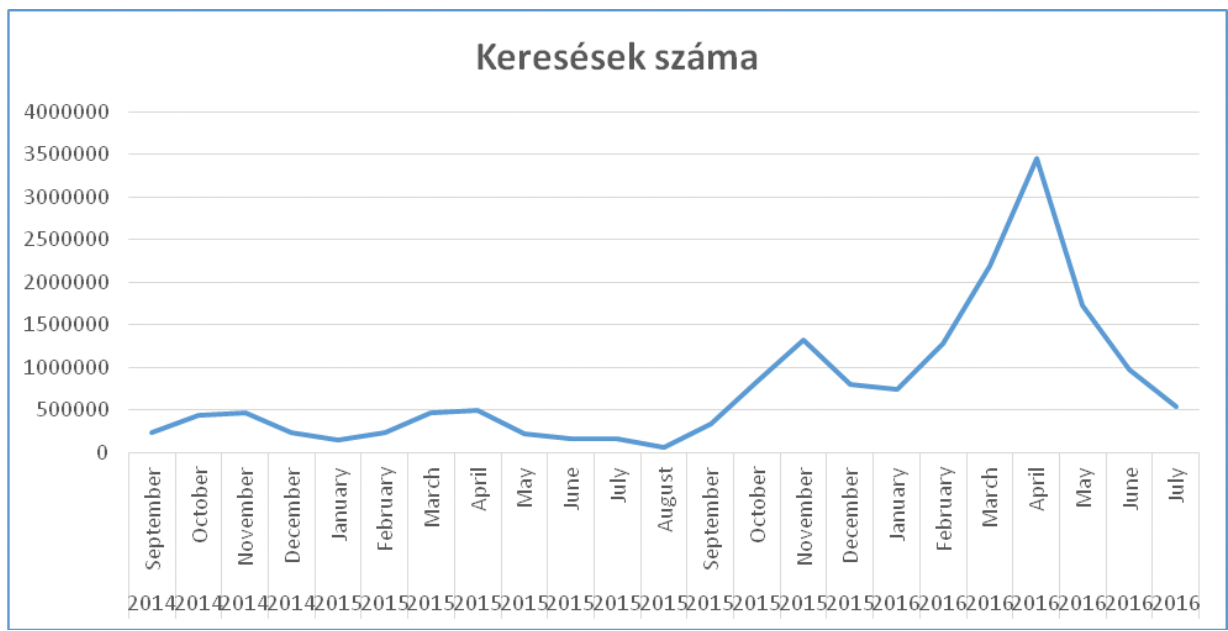

2. ábra. Keresések száma

Összegezve elmondhatjuk, hogy az EDS kereső bevezetése a statisztikák tükrében is jó döntésnek bizonyult, az idő előrehaladtával pedig azt látjuk, hogy a használók köre egyre szélesebbé válik. 


\section{Dizájn és használói felület}

Bevezetésekor a közöskereső-szolgáltatás még „EDS kereső” néven a honlap akkori dizájnjában egy külön keresődobozban került megjelenítésre, a honlap bal oldalán. Így, önállóan szerepeltetve nagyobb hangsúlyt kaphatott, mintha egybetettük volna a könyvtári katalógus, az e-folyóiratok, illetve a Google Scholar számára készített közös keresődobozzal, mely a honlap felső részében szerepelt (3. ábra).

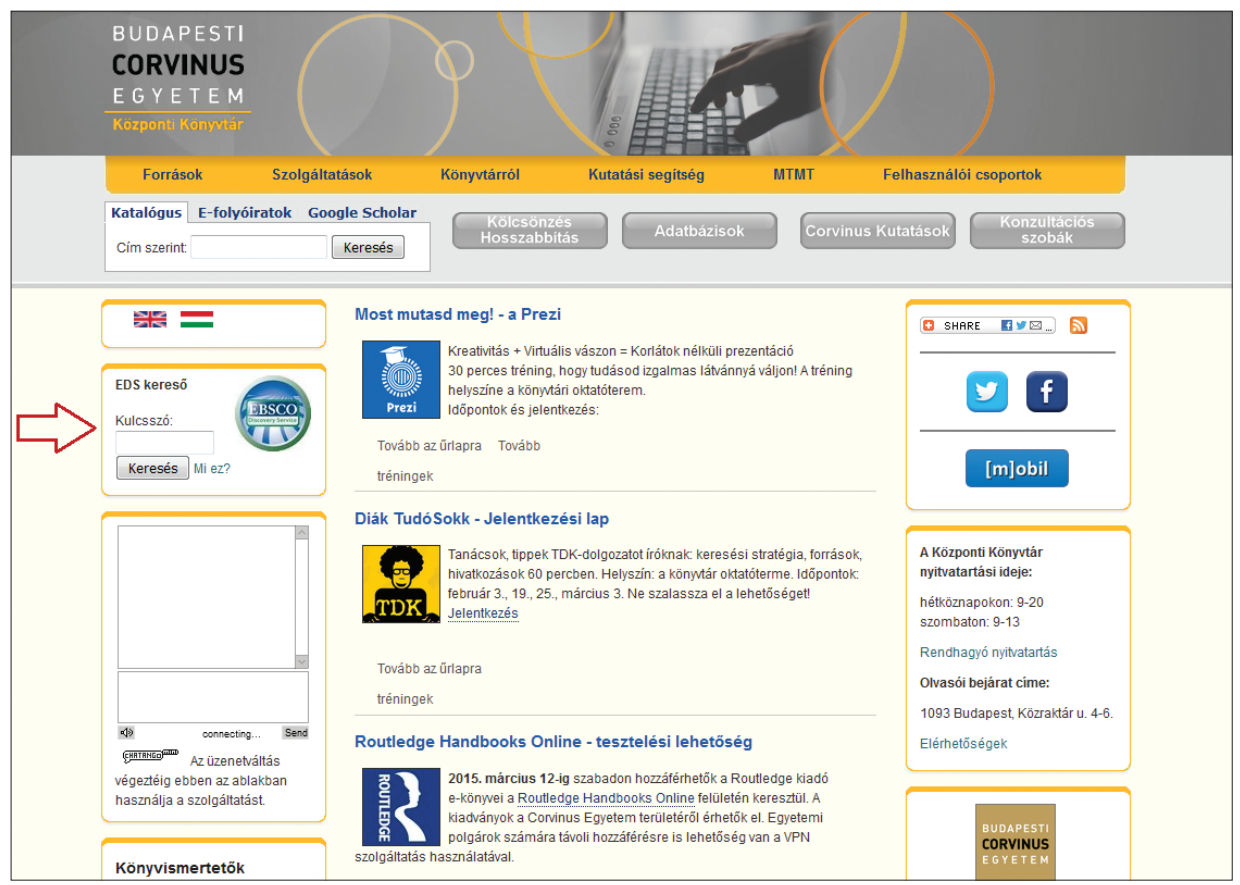

3. ábra. Az EDS kereső

2015 őszén új külsőt kapott a könyvtár honlapja ${ }^{1}$ Ekkor a már említett keresődobozok nagyobb felületet kaptak a kezdőlapon, melybe bekerült az EDS kereső is, a keresődobozban választható opciók közül az első helyen (4. ábra). A keresőmező mellé felkerült egy információs ikon, melyre kattintva az olvasók egy külön oldalon ${ }^{2}$ a Szuperkereső mibenlétéről, használatáról olvashatnak. Erre az oldalra egy rövid animációs kisfilm is felkerült, melyet a PowToon online animációkészítő programmal készítettek a könyvtáros kollégák, $\mathrm{s}$ amely szintén a Szuperkereső használatához ad tippeket (a videó honlapra történő beágyazása a könyvtár YouTube-csatornáján keresztül történt).

\footnotetext{
${ }^{1}$ Elérhetö: http://www.lib.uni-corvinus.hu (2016. október 29.)

2 Elérhetö: http://www.lib.uni-corvinus.hu/content/szuperkereso (2016. október 29.)
} 


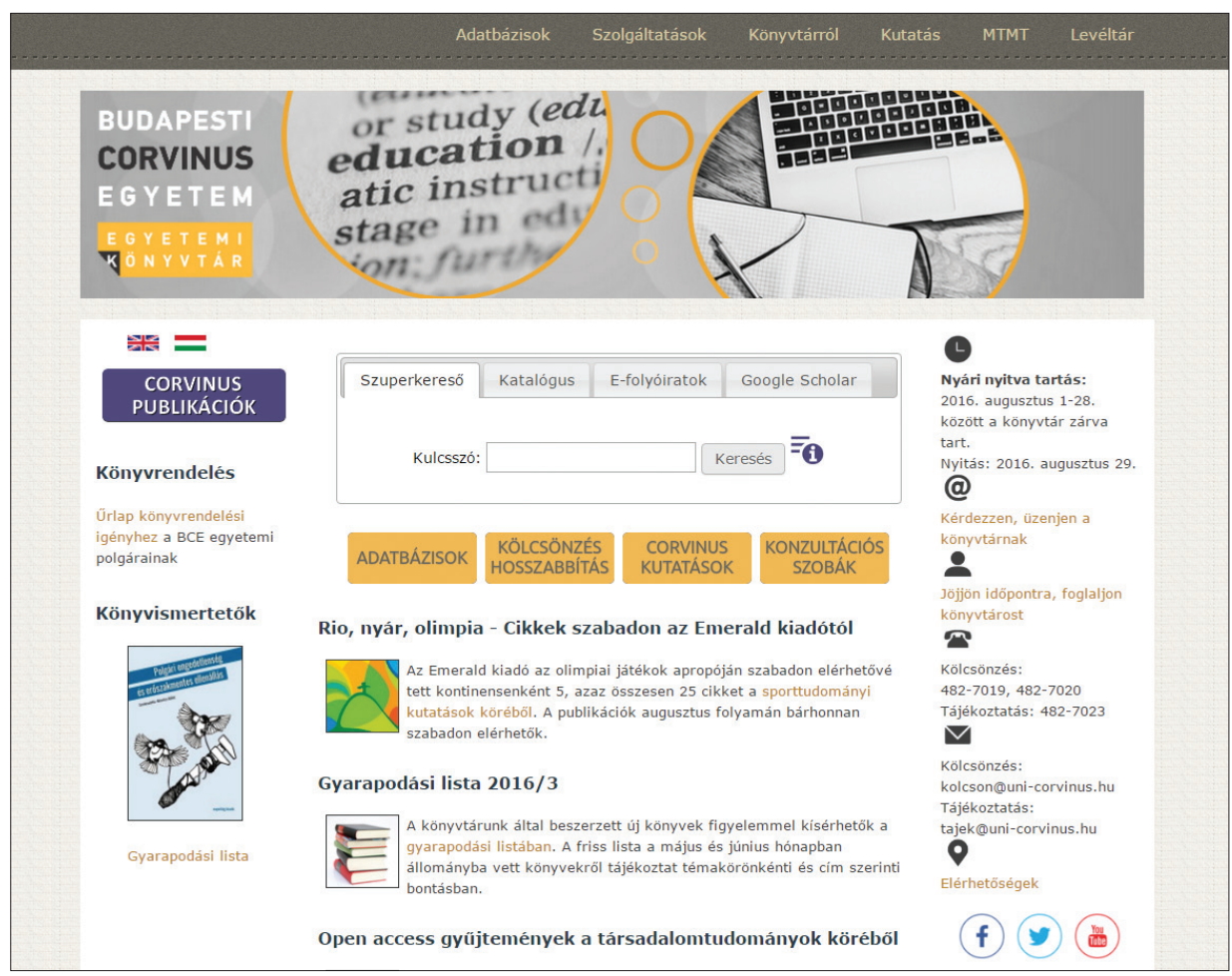

4. ábra. Az EDS kereső az új honlapon

A Szuperkereső, vagyis az EBSCO Discovery Service keresőfelülete több ponton testreszabható volt a dizájn egyes elemeitől a különböző keresési funkciók beállításáig. Ez utóbbiak nagy része az EBSCO adminisztrátori felületén keresztül elvégezhető. Ennek megfelelően a könyvtár EDS felületén meg tudtuk jeleníteni a logónkat, a menüsor színét pedig a könyvtár honlapjának színvilágához tudtuk igazítani. Választhattunk, hogy mi legyen a felület alapértelmezett nyelve: elöször a magyar mellett döntöttünk, majd figyelembe véve a külföldi hallgatók igényeit is, áttértünk alapértelmezetten az angol nyelv használatára (a magyar használata természetesen továbbra is választható opció maradt). A mellékelt képernyőfotón (5. ábra) mindezek mellett azt is láthatjuk, hogy hogyan jelenik meg a találati listában a katalógusból származó tételeknél a valós idejü példányinformáció. 


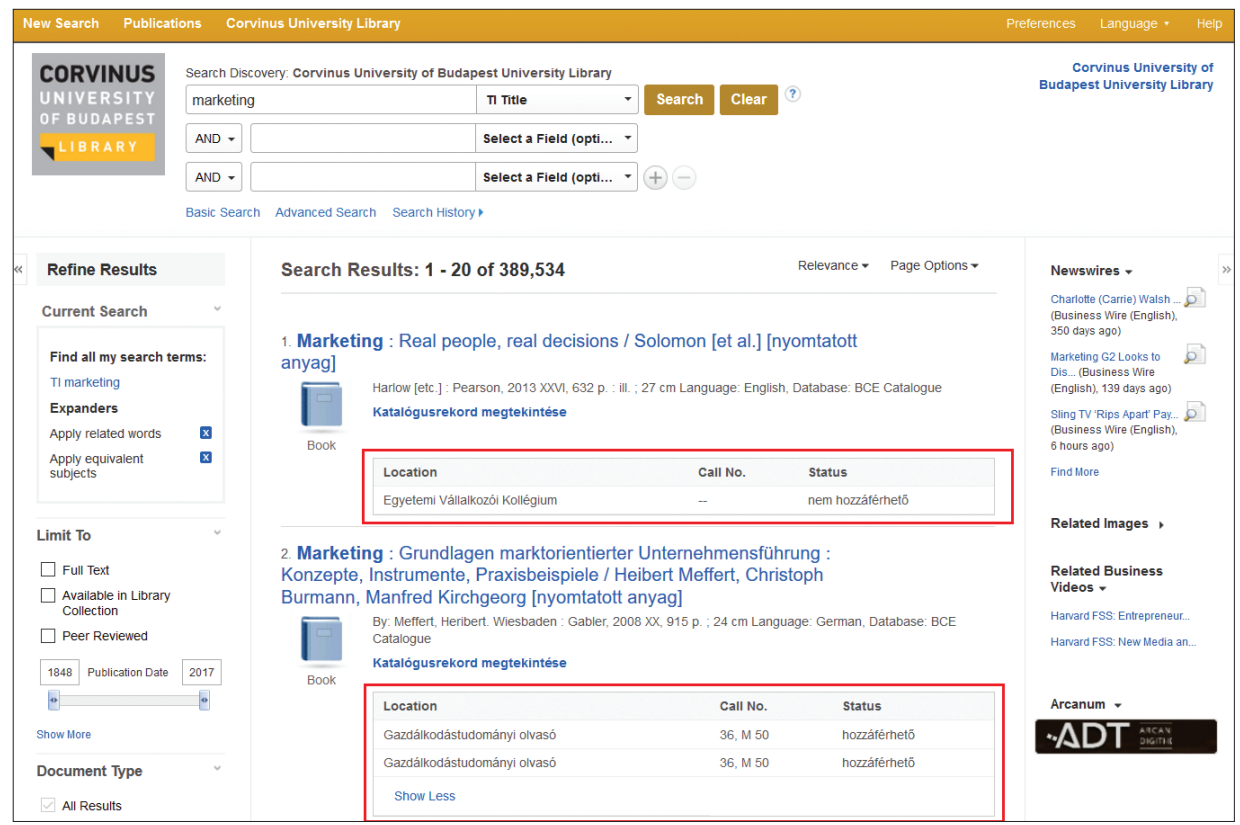

5. ábra. Találati lista valós idejü példányinformációkkal

\section{Összegzés}

Összefoglalva az eddigi tapasztalatokat elmondhatjuk, hogy a Budapesti Corvinus Egyetem Egyetemi Könyvtárában az EBSCO Discovery Service mint közöskereső-szolgáltatás bevezetése sikeres döntésnek bizonyult. Az EBSCO adatbázisok elterjedtsége révén a már ismerős keresőfelület is hozzájárult a szolgáltatás széleskörü használatához, amit a különböző statisztikák számadatai is bizonyítanak. A keresőrendszer számos ponton alakítható a könyvtár saját igényei szerint, lehetővé téve a könyvtáron keresztül elérhető forrásokban való minél hatékonyabb és gyorsabb keresést.

\section{Rezümé}

A Budapesti Corvinus Egyetem Egyetemi Könyvtára 2013-ban döntött úgy, hogy elökészíti és bevezeti az úgynevezett discovery (azaz közös kereső) szolgáltatást, mely egy felületen teszi kereshetővé a könyvtáron keresztül hozzáférhető tudományos adatbázisokat, elektronikus folyóiratokat és a könyvtári katalógust. Az EBSCO Discovery Service bevezetése - majd a közérthetőség jegyében a Szuperkereső névre való áttérés - a használati statisztikák tükrében sikeres döntésnek bizonyult. A közös kereső számos ponton alakítható igényeink szerint, lehetővé téve a könyvtáron keresztül elérhető forrásokban való minél hatékonyabb és gyorsabb keresést. 


\section{The Rise of the SuperSearch: EDS at Corvinus University}

In 2013 the University Library of Corvinus University of Budapest decided to prepare and introduce a discovery service in addition to its existing library services in order to make all the resources available in the Library (library catalogue, scientific databases and e-journals) searchable through a single interface. The introduction of EBSCO Discovery Service has proved to be a success in the light of the usage statistics. The common search interface can be customized according to the special needs of the Library, resulting hereby a more efficient and faster searching process.

BÖRZSÖNYI NÓRA

Elektronikus Tartalomkezelési Osztály Budapesti Corvinus Egyetem Egyetemi Könyvtár ORCID: 0000-0001-9327-0197 



\section{A Primo használata a Magyar Tudományos Akadémia Könyvtár és Információs Központban}

\section{A rendszer általános jellemzői}

A Primo szolgáltatás az Ex Libris, a ProQuest Company ${ }^{l}$ cégegyüttes portfóliójának része. A rendszer magyarországi forgalmazója és egyben a terméktámogatást adó cége az Ex-Lh Kft. ${ }^{2}$

A Primot jellemzően felhőalapú szolgáltatásként vehetik igénybe az egyes könyvtárak és információ-közvetítő intézmények online szolgáltatásaik fejlesztése érdekében. A szoftver a discovery and delivery rendszerek körébe tartozik, és azok összes kutatástámogató megoldásával rendelkezik. Ezen rendszerek legföbb jellemzője, hogy különbözö intelligens keresési technikák és eszközök használata révén minden eddiginél nagyobb hangsúlyt fektetnek az információ feltárásának és felfedezésének mozzanatára, függetlenül annak hordozójától, illetve ezzel párhuzamosan - mintegy az információkereső folyamat eredményeként - ,gondoskodnak” a könyvtár jogosultságainak megfelelően az információt tartalmazó dokumentumváltozatok (metaadat, hangzó-, képi-, multimédia-dokumentumok, absztraktok és teljes szövegek) felhasználó elé történő „szállításáról" is. További fontos tulajdonságuk az ún. egypontos keresés biztosítása, amely révén lehetőség van egyidejüleg elérni a könyvtár összes gyüjteményét (legyen szó akár a könyvtár online katalógusáról, a könyvtár által előfizetett adatbázisokról, illetve annak különböző digitális vagy elektronikus gyüjteményeiröl). Többségük központi indexszel rendelkezik (ez a Primo esetében a PCI - Primo Central Index), amely nemcsak több millió közvetlen rekordkapcsolatot jelent, hanem jelentősen meggyorsítja a keresés folyamatát is. Általában a szabványok széleskörü támogatása (pl.: MARC, DC, OpenSearch, OAI-PMH stb.) jellemzi öket, amely révén mintegy platform-független szolgáltatásként a legkülönfélébb rendszerekkel való együttmúködést tudják megvalósítani. ${ }^{3}$ Fontos jellemzőjük a találatok relevancia szerinti rendezése, továbbá az úgynevezett facetták alkalmazásával az adott esetben több tízezres találati halmaz különböző szempontok szerinti rendezése, szükítése, illetve ezt felhasználva új keresések ajánlása a felhasználóknak. Természetesen mindezen szolgáltatásokat felhasználóbarát és modern felületeken nyújtják, teret engedve a közvetlen felhasználói közremükö-

\footnotetext{
${ }^{1}$ http://www.exlibrisgroup.com (Utolsó letöltés: 2016. október 9.)

${ }^{2}$ http://www.ex-lh.hu/site/index.php/HU (Utolsó letöltés: 2016. október 9.)

${ }^{3}$ Ez az MTA KIK esetében - ahogy arról még lesz szó - az ALEPH, SFX, MetaLib, ADAM, JaDoX és EPrints szoftverek ,együttkezelését” jelenti.
} 
désnek is, például a rekordokhoz kapcsolódó kommentek, értékelések, címkézések formájában. ${ }^{4}$

\section{A Primo bevezetése az MTA KIK-ben}

A rendszer elindítására könyvtárunkban 2015 novemberében került sor, amelyet azonban mintegy 1 éves előkészítő fázis előzött meg. Ennek során a könyvtári igények megfogalmazása bizottsági munka keretében folyt, amelynek tagjai az Olvasószolgálati és Szakinformatikai Osztály munkatársai, illetve a könyvtári honlap felelősei voltak. Az igények közvetítése az Ex-Lh Kft. felé, a cég konfigurációt végző munkatársaival való folyamatos kapcsolattartás és a rendszerdokumentáció megismerése a Szakinformatikai Osztály feladata volt. A szükséges tesztelésekre kibővített munkatársi körben - törekedve lehetöleg minél több, elsősorban olvasószolgálatos kolléga bevonására - került sor.

Alapvetően két területre koncentrált a munka: egyrészt a formai-technikai problémák megoldására, másrészt a kívánatos tartalmi működés kialakítására.

A formai-technikai problémák közül elsőként a Primo kezdőképernyő tartalmának és megjelenésének kialakítására került sor. Megegyezés született arról, hogy a Primo lesz a könyvtár szolgáltatási felülete. Ennek kapcsán meghatározásra került, hogy az MTA KIK honlapjáról mik kerülnek (önállóan vagy megosztva) át az új felületre: a könyvtári szolgáltatásokkal kapcsolatos hírek, aktualitások mellett a dokumentum-előkészítés (lefoglalás) igénylése, az adatbázis, e-folyóirat, e-könyv A-Z listák, a keresési csoportok (scope-ok) részletes leírásai és egyéb tájékozódást, keresést segítő funkciók (linkgyüjtemény, könyvajánló) kaptak helyet az oldalon. Fontos alapelv volt, hogy az új felület színvilágának, dizájnelemeinek meg kell egyezniük a könyvtári honlap kialakításával. Ennek megfelelöen lettek megtervezve a honlap fejlécének képi elemei is. Tudva, hogy napjainkban egy jól megválasztott elnevezés nagyban befolyásolhatja egy rendszer bevezetésének sikerességét, csak hosszas mérlegelés után történt meg a névadás. A MTA KIK Primoja végül a metakereső szó és a könyvtár nevének rövidítéséből a $\mathrm{M}[\mathrm{e}] \mathrm{TAK}$ elnevezést kapta.

A munka következő szakaszában a szerkezeti elemek igazítására, a rendszer működése során használt üzenetek hibáinak javítására, a fordítások véglegesítésére, a különböző karakterkódolási problémák kiküszöbölésére került sor. A különböző rendszerfunkciók (beállítások, mentések, értesítések) és a kényelmi szolgáltatások (pl. e-polc használat, elöjegyzés) müködésének ellenőrzése sem maradhatott el.

Tartalmi szempontból az első lépés annak meghatározása volt, hogy mely gyüjteményeket, adatbázisokat, és milyen csoportosításban akarunk kereshetővé

${ }^{4}$ A közös jellemzők részletes ismertetését 1.: Dávid Adrienn: Hol tart a következő generációs katalógus? 260 amerikai és kanadai egyetemi könyvtár online katalógusának vizsgálatát bemutató tanulmány. = Tudományos és Müszaki Tájékoztatás, 62. évf. 2015. 1. sz. 28-31. 
tenni a Primoval. A könyvtári katalógus és repozitórium (REAL - EPrints), valamint az elöfizetett adatbázisok mellett az akadémiai intézetek, az országos, nagy könyvtárak katalógusaiból, valamint az Akadémiai Könyvtár és partnerei által létrehozott digitális Képkönyvtár (JaDoX) anyagaiból került kialakításra egy-egy keresőcsoport (scope). Ezek mellett természetesen az összes gyüjteményben egyszerre történő keresésre is lehetőség van a Keresés mindenben opcióval. Folyamatos tesztelésekkel ellenőriztük az adatok megjelenítésének pontosságát, azok könyvtári adatbázissal való egyezőségét, a megfelelő indexelést és visszakereshetőséget. Az ellenőrzési folyamathoz kapcsolódóan fontos lépés volt a Primo-rekordok belső szerkezetének megismerése. A rendszer a beérkező, különböző szabványok alapján készült, eltérő felépítésű külső rekordokból egy egységes szerkezetủ belső, úgynevezett PNX-rekordot ${ }^{5}$ hoz létre, $\mathrm{s}$ ezt használja aztán az adatmegjelenítés és az indexelés során. A rekordok szekciókból, ${ }^{6}$ a szekciók adatmezőkből épülnek fel, az adatmezők pedig minden nagy szabvány adatstruktúrájával megfeleltetésben vannak ('́gy például a MARC21 szabvány esetében is a leggyakrabban használt MARC-mezők megfeleltetését tartalmazza a rendszer). Ezenfelül minden szekcióban további $50 \mathrm{db}$ úgynevezett lokális mező definiálható az esetleges egyedi adatmegjelenítésre és indexelési igényekhez. Az MTA KIK-ben a mezőmegfeleltetések ellenőrzése és finomítása még folyamatban van, hogy minél pontosabb és hatékonyabb megjelenítést és visszakereshetőséget biztosíthassunk. Az alábbi táblázatban néhány, könyvtárunkban alkalmazott mezőpárosítás látható:

\begin{tabular}{|l|l|l|}
\hline \multicolumn{1}{|c|}{ Szekció } & \multicolumn{1}{|c|}{ PNX-adatmezö } & \multicolumn{1}{c|}{ MARC 21 adatmezö } \\
\hline Display & Creator & 100 abcdejqu; 110 abcde; 111 abcdn \\
\hline & Title & $245 \# \# \$$ abfgknp; 130\#\#adfklmnoprs \\
\hline & Subject & minden $6 \mathrm{xx}$ mező \\
\hline Search & creatorcontrib & $100,110 \ldots 245 \$ \$ \mathrm{c}, 505,508,7 \mathrm{xx}, 8 \mathrm{xx}$ \\
\hline & Description & $520 \$ \$ \mathrm{a}$ \\
\hline & ISBN & $020 \mathrm{az}$ \\
\hline Facets & Language & $008 / 35-37 .+041 \$ \$ \mathrm{a}, \mathrm{d}, \mathrm{e}$ \\
\hline Browse & Author & $1 \mathrm{xx}, 7 \mathrm{xx}, 8 \mathrm{xx}$ \\
\hline
\end{tabular}

1. táblázat. PNX- MARC-mezők megfeleltetése (MTA KIK Primo)

${ }^{5}$ A rövidítés feloldása: Primo Normalized XML. A PNX-rekordot egy showPnx nevü Chrome-bővítmény segítségével lehet megjeleníteni. A bővítmény letölthető pl. innen: https:// chrome.google.com/webstore/detail/showpnx-for-exlibris-prim/nnibcklgecdkccooecjdoadbkifnm djc\# (2016. október 4.)

${ }^{6}$ Az egyes szekciók a bibliográfiai rekordokban rögzített adatok különböző felhasználási „területeit” jelölik (pl.: Display=Részletes megjelenítés, Search= a Keresési index, Browse= Böngészés, Facets $=$ Facetták stb.) 
A tesztelési időszakban jó néhány újszerü - a „hagyományos” könyvtári katalógustól eltérö - megoldással és nehezen kezelhető hibával is szembe kellett néznünk. A teljesség igénye nélkül néhány ezek közül: Primoban a könyvtári katalógus indexelése nem a könyvtári rendszerben (Aleph) kialakított paraméterek szerint történik; ${ }^{7}$ problémát jelentett a bibliográfiai rekordokhoz kapcsolódó digitális rész-objektumok (címlap, tartalomjegyzék), ill. MetaLib-es kapcsolatokon alapuló rekordkapcsolatok (katalógustétel) „teljes szövegként” való megjelenítése; ${ }^{8}$ a 856-os MARC-mező eltérő müködése az Aleph-ben és a Primo-ban; ${ }^{9}$ egyelöre még mindig nem megoldott a kikölcsönzött és a nem-hozzáférhető státusz egy speciális változatának ugyanazon kategóriába sorolása; ${ }^{10}$ a dokumentumtípusok meghatározásának forrása nem a katalógusrekordok FMT-mezője, hanem az LDR és 008-as mezők, így a Primoban való helyes megjelenítés érdekében újra kell gondolni azok használatát a katalogizálás során.

A bevezetési szakasz előkészítési és tesztelési munkái nagyon sok új ismeretet és tapasztalatot adtak a könyvtárosoknak. Fontos tanulság volt, hogy a rendszerben rejlő lehetőségek minél nagyobb fokú kihasználása érdekében a könyvtárosoknak törekedniük kell a rendszerrel kapcsolatos fellelhetö technikai anyagok megismerésére, az alapos, sokrétü tesztelésre, és ezek alapján a folyamatos konzultációra a szolgáltató cég munkatársaival.

\section{A Primo müködése az MTA KIK-ben}

A tesztelési időszak végére sikerült az elképzeléseinknek megfelelő megjelenítést és - néhány hibától eltekintve - megfelelő, a szolgáltatásokat hatékonyan támogató müködést kialakítani. A megmaradt hibák javításán, valamint a felmerülő szolgáltatásbővítő igények kezelésén folyamatosan dolgozunk. Az alábbiakban a müködés bemutatásán keresztül szeretném ismertetni az elért eredményeket.

Az előzőekben már szó volt a nyitóoldal kialakításának koncepciójáról és annak szerkezetéről. A müködés szempontjából a kezdőoldal legfontosabb eleme a felső harmadban található keresődoboz. A felhasználónak itt van lehetősége egyetlen keresőmezőben lekérdezni az egyes keresőcsoportokban meghatározott adatbázisokat (vagy akár a teljes gyüjteményt: Keresés mindenben). A keresőkifejezés(ek) megadása - amely során az ismert logikai operátorokat,

${ }^{7}$ A keresést nem az ALEPH index-táblái vezérlik, hanem a Primo saját indexelési eljárása, ami a fentebb már tárgyalt PNX-MARC21 megfeleltetésen alapul.

${ }^{8}$ A rész-objektumok vonatkozásában a problémát sikerült kezelni, de a távoli katalógusok tételeire mutató kapcsolatok továbbra is „teljes szövegként” jelennek meg a Primo felületén.

${ }^{9}$ ALEPH-ben a 856-os mező első indikátorával (4) jelezni lehet, hogy a mezöben megjelenített webcím a 'http' protokollt használja, így azt már a linkbe nem kellett beleírni. A Primo-nak viszont „szüksége” van a protokoll megjelenítésére a címben, mert anélkül hibás címként értelmezi.

${ }^{10}$ Kiadva innen státusban jelenik meg mindkettő. A probléma megoldásához a példányrekordokban használatos feldolgozási státuszok szerepét kell meghatározni a Primo számára. 
illetve helyettesítő karaktereket is használhatja -, és a megfelelő scope ${ }^{11}$ kiválasztása után indulhat a keresés.

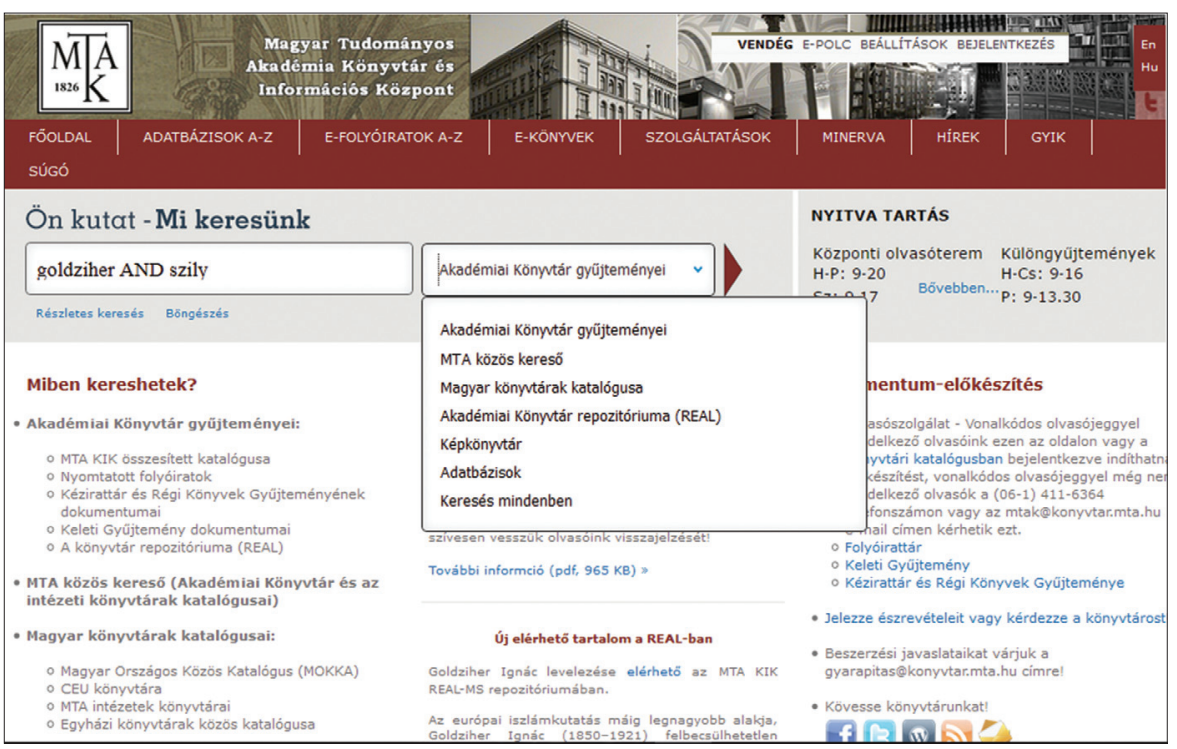

1. ábra. A nyitóoldal és a keresődoboz

Az egyszerü keresés mellett lehetőség van összetett és böngészö lekérdezésre is. A részletes keresésnél már több mezőt használhatunk egyidejüleg, továbbá különböző szükítési lehetőségek állnak rendelkezésünkre. ${ }^{12}$

\begin{tabular}{|c|c|c|}
\hline mint szerzö/alkotó $\vee$ mely ezz tartalmazza: $\checkmark$ kosáry & $\begin{array}{l}\text { Publikáció } \\
\text { dátuma: }\end{array}$ & $E$ Elozzö 20 év \\
\hline$\checkmark$ mely ezt tartalmazza: $\checkmark$ magyar & Anyagtipus & Könyvek \\
\hline \multirow[t]{4}{*}{$\checkmark$ mely ezt tartalmazza: $\checkmark$ ] } & Nyelv: & Magyar \\
\hline & Kezdôdátum: & Nap $\vee$ Hónap $\vee$ Év $(0000$ \\
\hline & Záródátum: & Nap $\vee \checkmark$ Hónap $v$ Év $(\infty \infty \infty)$ \\
\hline & Keresés itt: & Akadémiai Könyvtár gyüjteményei $v$ \\
\hline Egyszerũ keresés & & \\
\hline
\end{tabular}

\section{2. ábra. A részletes keresés mezői}

${ }^{11}$ Az Akadémiai Könyvtár gyüjteményei csoport az Aleph-katalógus, ill. a REAL dokumentumait tartalmazza, míg a REAL ezenkívül külön csoportként is szerepel. Az Aleph-adatok frissítése minden éjszaka megtörténik. A Primo Dublin Core formátumú exportként veszi át a REALrekordokat. Az Adatbázisok csoport közvetlenül a PCI-t (Primo Central Index) használja, míg a többi keresőcsoport a MetaLib nevü rendszeren keresztül, annak beállításait használva érkezik a Primoba.

${ }^{12}$ Esetükben, ahogy azt a 2. ábra is mutatja, három keresőmezó áll a felhasználók rendelkezésére, továbbá a publikáció dátumára, anyagtípusára, nyelvére is szükíthetünk. Emellett természetesen keresőcsoportot is választhatunk. 
Böngészésnél négy listából (tárgyszó, szerző, cím és raktári szám) választhatunk, majd a lista tételeire kattintva juthatunk a részletes leíráshoz és a példányadatokhoz.

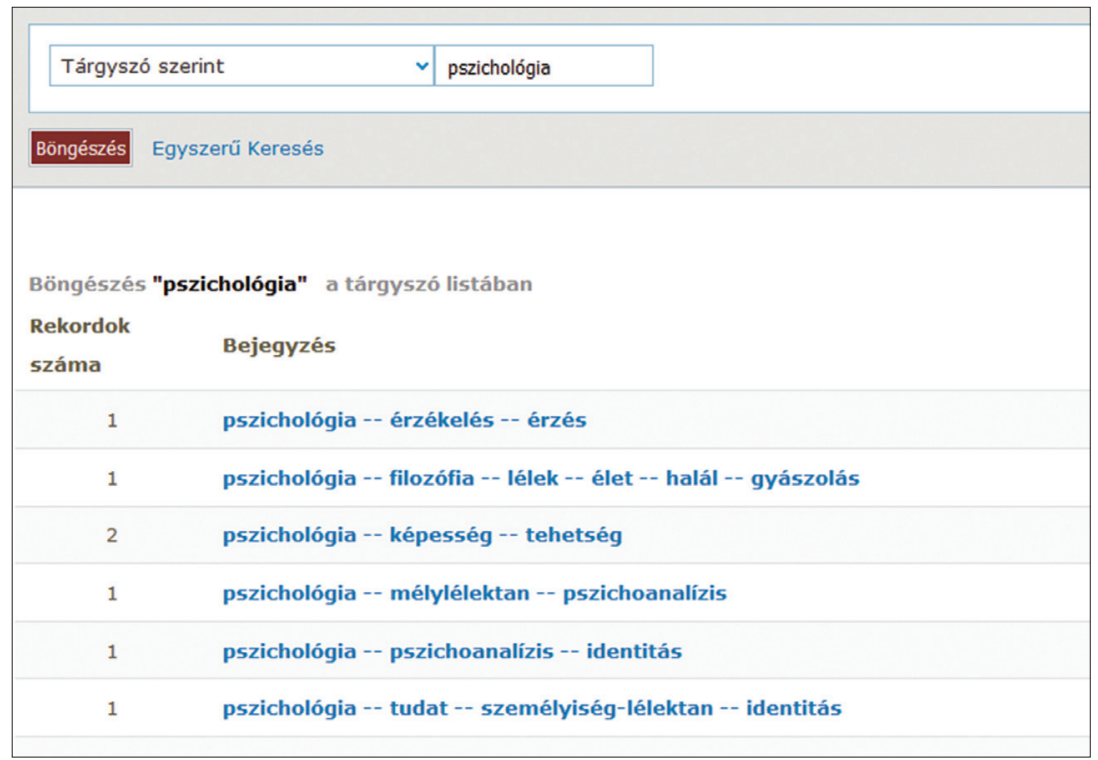

\section{3. ábra. Böngészés}

A keresés után elsőként egy rövid formátumú találati listában jeleníti meg a rendszer a releváns rekordokat. A lista tetején a keresőkifejezéssel kapcsolatos találatszám mellett az egy oldalon megjelenő tételek számát láthatjuk. ${ }^{13} \mathrm{~A}$ találatok rendezésének elve a relevancia, a fontosság. ${ }^{14}$ A Primoban a relevancia bonyolult algoritmusok alapján határozódik meg, amelynek bizonyos vonatkozásait befolyásolni lehet a MARC-mezők egymáshoz való viszonya alapján. ${ }^{15} \mathrm{~A}$ találati listában az egyes tételek legfontosabb bibliográfiai adatai jelennek meg - szerző, cím, kiadási év - a dokumentumtípusra utaló ikonokkal együtt. Közvetlenül alattuk

${ }^{13} \mathrm{Az}$ egy oldalon megjelenő találatok száma az összes keresőcsoport vonatkozásában $50 \mathrm{db}$. A MetaLibes forrásokat tartalmazó keresőcsoportok esetében ezen túl - relevancia alapján - még egy úgynevezett „első körös” találati kört is meghatároz a rendszer, amely minden érintett adatbázisból maximum $30 \mathrm{db}$ rekordot tartalmaz. Természetesen lehetőség van ezen találati halmaz bővítésére is a Több találat megjelenitése? gombra kattintva. Az új tételek külön jelzést kapnak a találati listában (4. ábra).

${ }^{14}$ Ezenkívül dátum, szerző és cím szerinti rendezésre van lehetőségünk.

${ }^{15}$ Az úgynevezett boostingolással (vagy boosterolással) különbözö értékeket lehet adni a releváns MARC-mezőknek (Szerző, Cím, Tárgyszó), amivel befolyásolni lehet egy rekord - a keresőkifejezés és az adott MARC-mező egyezősége alapján - találati listában elfoglalt helyét. Ezenkívül lehetőség van a helyi rekordok előnybe részesítésére is a távoli tételekkel szemben. 
látható a mü elérhetőségére vonatkozó információ (pl.: Hozzáférhető itt, Kiadva, Online forrás). A könnyebb átláthatóság és kezelhetőség érdekében a rendszer a részben megegyező adatokkal rendelkező rekordokat csoportosítja. ${ }^{16} \mathrm{~A}$ csoportosított rekordokból a találati listában egy kerül kiemelésre, a többit a További változatok (vagy Verziók megtekintése) gombokra kattintva lehet megnyitni (5. ábra).

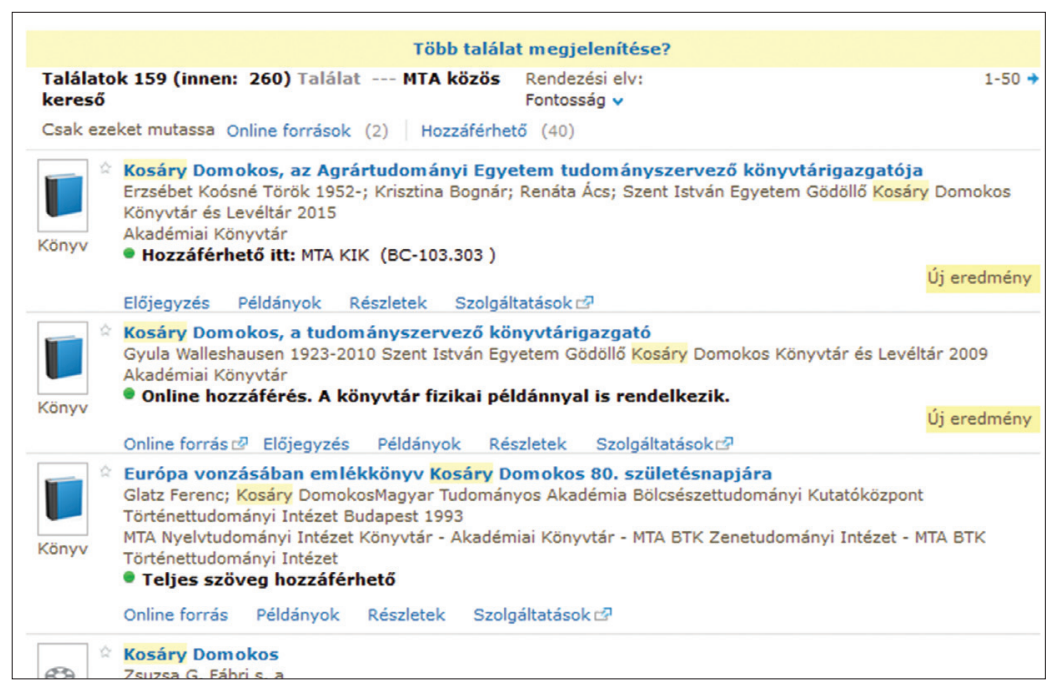

4. ábra. Első körös találati lista

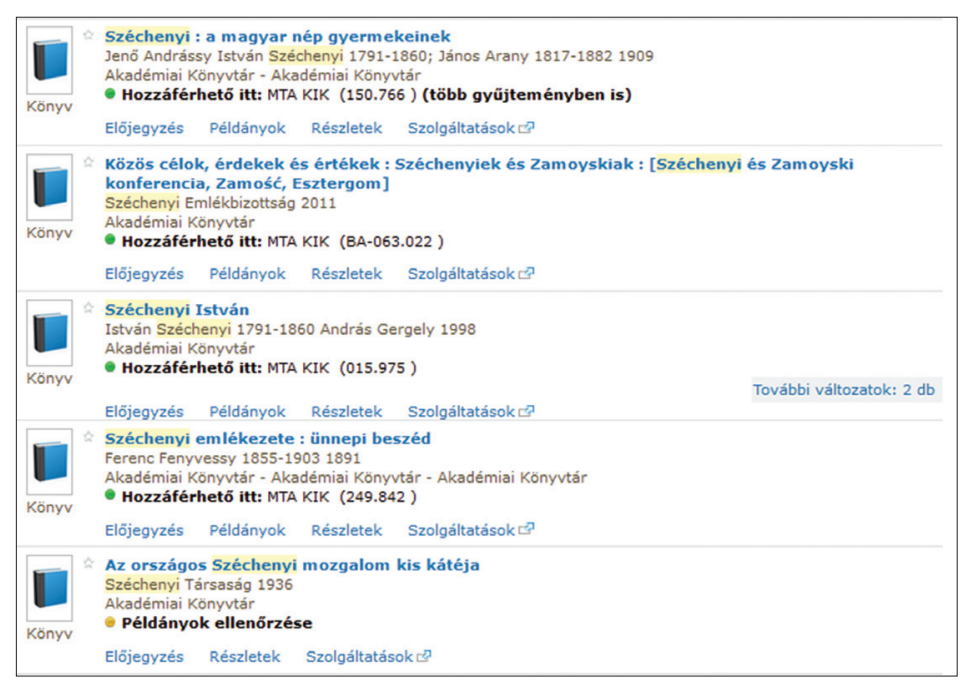

\section{5. ábra. Találati lista - csoportosítás}

${ }^{16}$ Primoban a csoportosítás az FRBR-modell (Functional Requirements for Bibliographic Records) alapelvei szerint történik. 
A fentiek mellett további szolgáltatások érhetők el a rövid formátumú megjelenítésből. A Részletek alatt egyrészt a bővebb bibliográfiai leírást találjuk, ${ }^{17}$ másrészt a Linkek ablakból a könyvtári katalógushoz, a tételhez kapcsolódó objektumokhoz vagy éppen a teljes szöveghez juthatunk el. A Példányok fül alatt van lehetőségünk a részletes elhelyezési adatokat megtekinteni. ${ }^{18} \mathrm{~A}$ rendszerbe való bejelentkezés után, innen és az Elöjegyzések fül alól is kezdeményezhetjük a példány elöjegyzését. ${ }^{19}$ A Szolgáltatások alatt az SFX linkfeloldásai érhetők el, amelyek révén az adott mü további elérhetőségeit fedezhetjük fel.

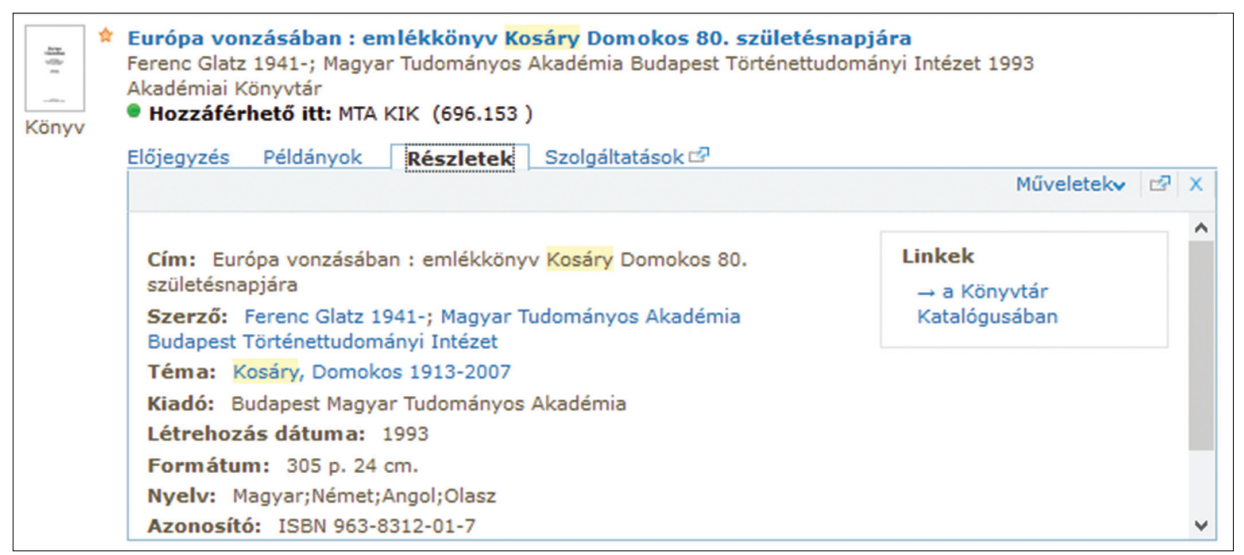

6. ábra. A tételhez kapcsolódó szolgáltatások és a Részletek ablak

A Primo ún. facetták révén meghatározott szempontok alapján csoportosíthatja a teljes találati listát, jelentősen megkönnyítve a felhasználó dolgát. A facetták a találati lista bal oldalán helyezkednek el, esetünkben a gyüjtemény, létrehozás dátuma ${ }^{20}$, nyelv, téma és alkotó lehetöségek vannak definiálva. Ezenkívül a találati halmazra építve szerző és tárgyszó alapján a témához illeszkedő új kereséseket is ajánl a rendszer. A nyitólapon egy-egy facettában néhány tétel jelenik meg, míg a További opciók linkre kattintva az egy csoporton belüli összes előfordulást látjuk.

${ }^{17} \mathrm{Az}$ alapadatok mellett itt már megtaláljuk a tárgyszólistát, vagy éppen a nyelvre, formátumra vonatkozó adatokat.

${ }^{18}$ Például raktári jelzet, vonalkód, példánystátusz.

${ }^{19} \mathrm{Az}$ elöjegyzés során csak az átvétel helyét kell maghatároznunk (Kölcsönzőpult, Olvasóterem).

${ }^{20}$ Ebben a facettában normalizálva sorolja be a találati listában szereplő dátumokat a rendszer. Az 1899 elötti dátumokat századra (1826 $\rightarrow$ 1800), az 1900-1949 közötti évszámokat tizedre $(1933 \rightarrow 1930)$ kerekíti, az 1950 utániakat viszont változatlanul hagyja a rendszer. 


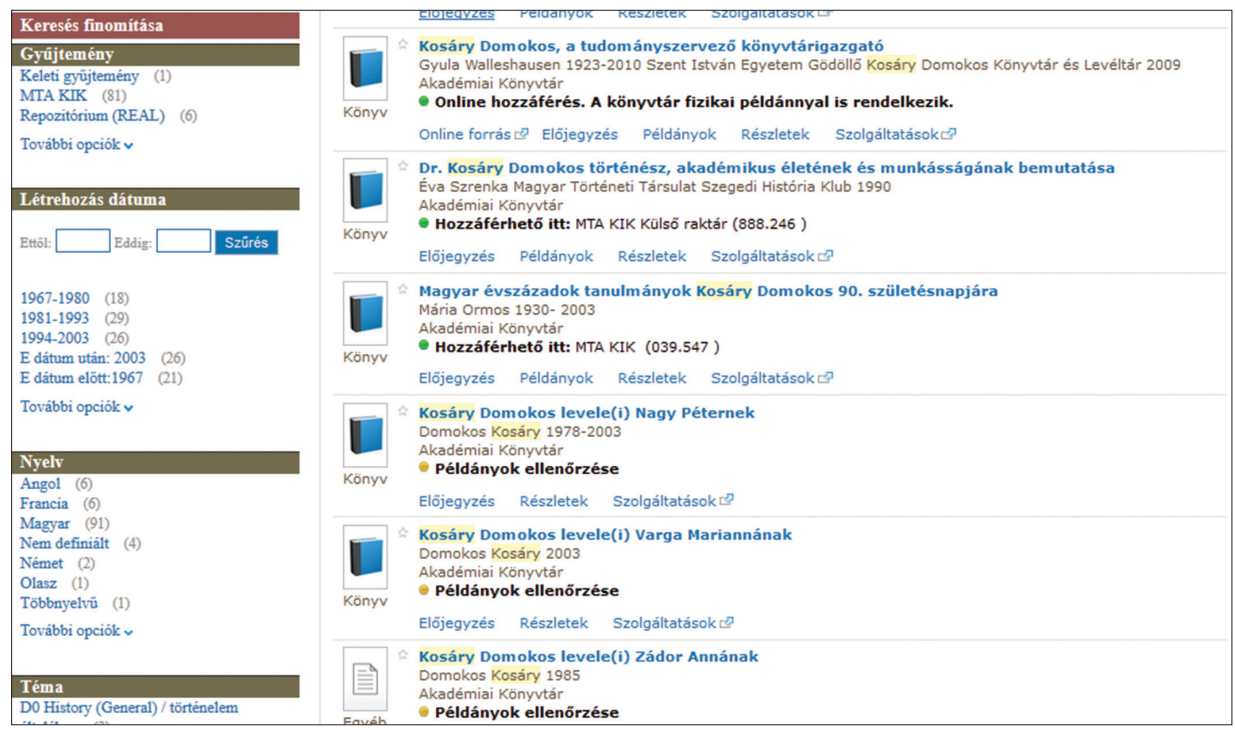

\section{7. ábra. Facetták}

A szoftver számos kényelmi szolgáltatást nyújt a felhasználóknak. Lehetőség van például a találatok egyenkénti és csoportos (teljes találati lap) mentésére, a keresőkérdés mentésekor témafigyelés beállítására, a találati listában megjelenő tételek nyomtatására vagy e-mailben való elküldésére, bibliográfiai szerkesztőprogramba (pl. EasyBib) exportálására, a rekord állandó linkjének (permalink) lekérésére, vagy a bibliográfiai adatokból különböző típusú idézetek szerkesztésére.

Bejelentkezés után igénybe vehetjük a rendszer e-Polc szolgáltatásait a keresés során elmentett dokumentumaink kezelésére, a kölcsönzési adataink ellenőrzésére, vagy saját adatbáziscsoportok kialakítására. A kereséskor elmentett tételeinknek a kosárban mappákat hozhatunk létre, amelyekkel tematikusan szortírozhatjuk őket a könnyebb áttekinthetőség érdekében. A tételeket egyesével, illetve csoportosan is menedzselhetjük innen is. Figyelemmel kísérhetjük kölcsönzéseinket, elöjegyzéseinket és pénzügyi adatainkat, lehetőségünk van kölcsönzéseink meghosszabbítására. Szintén az e-Polc-on tudunk az adatbázis A-Z listából választva saját adatbáziscsoportokat kialakítani, amelyek aztán a további keresések során önálló keresési tartományként müködnek. 


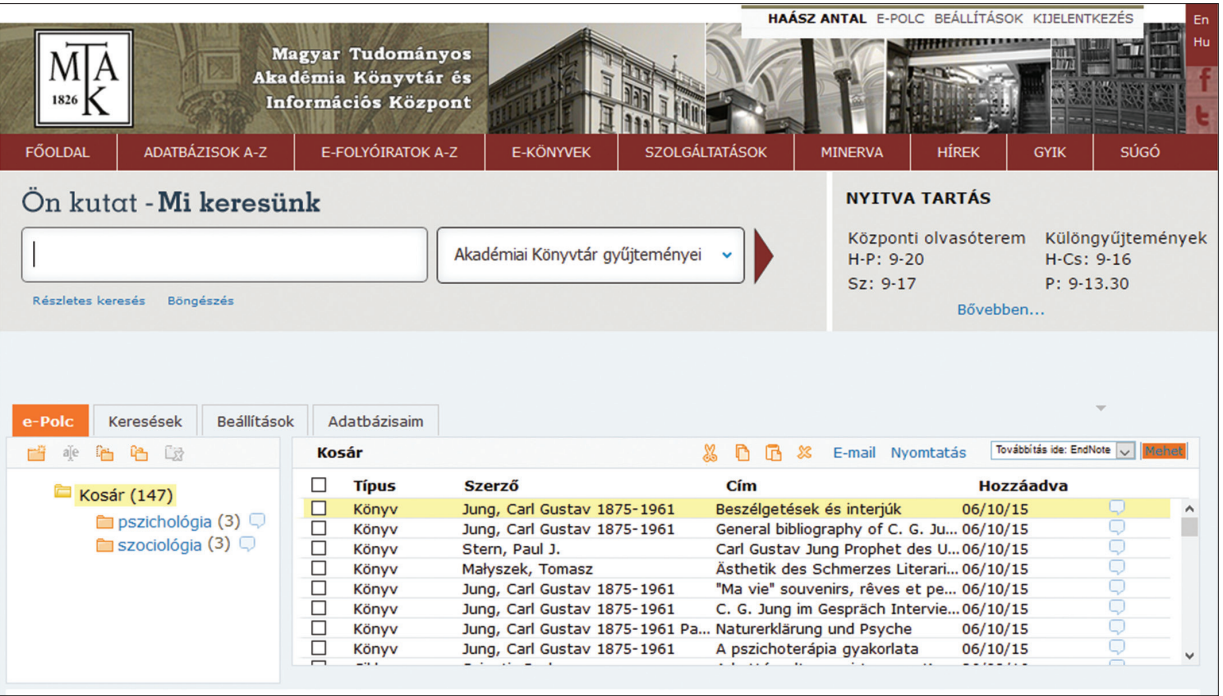

8. ábra. A Primo e-Polca

\begin{tabular}{|l|l|}
\hline Ön kutat - Mi keresünk \\
\hline Részletes keresés Böngészés \\
Miben kereshetek?
\end{tabular}

9. ábra. Saját keresőcsoport a keresési tartományok között

\section{Záró gondolatok}

Úgy gondolom, hogy egy megfelelő discovery rendszer megtalálása és alkalmazása, a felhasználói és technológiai igények nagymérvű megváltozása következtésben fontos és elengedhetetlen lépés minden fejlödni kívánó könyvtár életében. A döntés nem kis kockázattal jár: vajon a nem kis anyagi áldozatok árán megszerzett rendszer beváltja-e a hozzáfüzött reményeket? Képes lesz-e általa a könyvtár hatékonyan menedzselni elektronikus szolgáltatásait? Elnyeri-e a felhasználók tetszését? 
Az elmúlt közel másfél év tapasztalatai alapján az a személyes véleményem alakult ki, hogy - bár jelenleg is dolgozunk a hibák javításán és bizonyos szolgáltatások hatékonyabbá tételén, valamint további lépéseket kell tennünk a rendszer nagyobb használói elfogadottságáért - a Primo jó választásnak bizonyult az MTA KIK-ben. A rendszer képes az egyik legnagyobb tudományos szakkönyvtár információs vagyonának hatékony kezelésére, és annak eredményes közvetítésére a felhasználók felé.

\section{Rezümé}

A Primo egy felhőtechnológián alapuló discovery and delivery rendszer, amely képes biztosítani a könyvtári gyüjtemények teljes körủ és intuitív visszakereshetőségét. Az MTA KIK közel 1 éves bevezetési fázis után 2015 novemberében nyitotta meg a rendszer használatát felhasználói elött. A tesztidőszak alatt megoldásra kerültek a legfontosabb technikai és tartalmi problémák. A szolgáltatás nyitóoldala egyben a könyvtár szolgáltatási felülete is. Ennek megfelelően az aktualitás hírek mellett a keresőrendszerekkel és a dokumentumszolgáltatással kapcsolatos információk kaptak helyet az oldalon. A kereséshez hat keresőcsoport lett meghatározva: a könyvtár katalógusa, képkönyvtára, repozitóriuma és előfizetett adatbázisai (illetve egyéb szabadon elérhető források) mellett az akadémiai intézetek és fontosabb országos katalógusok rekordjai, rész- és teljes szövegủ dokumentumai kereshetők le a rendszerben. A tanulmány képernyőképekkel illusztrálva, részletesen ismerteti a szoftver müködését: a különböző keresési lehetőségeket, a találati lista szerkezetét, az adatmegjelenítést és példánykezelést. Az írás emellett kitér a találati halmaz csoportosítását végző facetták, és az elérhető kényelmi szolgáltatások bemutatásra is. Végezetül a szerző - az elmúlt közel másfél év tapasztalatának tükrében - néhány sorban értékeli a szoftver használhatóságát egy tudományos szakkönyvtár életében.

\section{Using Primo in the Library and Information Centre of the Hungarian Academy of Sciences}

Primo is a cloud technology based discovery and delivery system that can provide the full and intuitive retrieval of library collections. In November 2015, after almost 1 year test period the library made the system accessible for the users. During the test period the most important technical and database problems were solved. The home page of the service is the interface of the services of the library at the same time. Accordingly the latest news, information regarding the query system and the document delivery services are located on the page. Six scopes were defined for the search: the catalogue, the image collection and the repository of the library, the subscribed databases (and a few free one), the catalogues of the institutions of the academy and some main national catalogues with their full text documents. The paper illustrated with screenshots presents in detail the operation of the software: the different ways of searching, the structure of the search result lists, the data view and the copy management. Besides the paper presents the facets 
that group the results and the available convenience options, too. In the last few lines the author - summing up the experiences of the last one and a half year - evaluates the usefulness of the software in a scientific research library.

HAÁSZ ANTAL osztályvezető-helyettes MTA KIK Szakinformatikai Osztály 


\section{OPAC 2.0 az ELTE-n}

\section{Webkettes technológiákra épülő VuFind könyvtári keresőszoftver}

\section{A web 2.0-tól az OPAC 2.0-ig}

A web 2.0 elnevezés 2001-ben hangzott el elöször, és attól kezdve rohamosan terjedni kezdett. ${ }^{1}$ A kifejezés olyan közösségre épülő web alapú szolgáltatások gyüjtöneve, ahol a felhasználók közösen készítik a tartalmakat vagy osztják meg egymás információit. A web 2.0 könyvtári szolgáltatásokra való kiterjesztéséből született a könyvtár 2.0 elnevezés, melyben az információáramlás már nem egyirányú, a felhasználói közönség maga is alakítja a könyvtári szolgáltatásokat, s így fokozódik a közösségi részvétel, a visszajelzés. A web 2.0-s lehetőséggel az online katalógusok (Online Public Access Catalog, OPAC) is nagyobb felhasználói élményt nyújtanak, úgymond közösségibbé válnak például az olvasó számára fontos, szürt információk megjelenítésével, vagy a tartalom szabad címkézésével.

Könyvtári oldalról alapvető, megoldandó feladat, hogy az olvasónak ne kelljen több adatbázisban, katalógusban keresni, ha információhoz szeretne jutni. Ennek technikai megoldása a közös keresők, a discovery eszközök használata, amelyek egypontos keresési felületet biztosítanak a könyvtár adatbázisai számára. Alkalmazásukkal tehát többféle könyvtári rendszert kell „közös nevezőre” hozni. Amellett, hogy rövidül a keresési idő, előnye, hogy a web2-es kényelmi szolgáltatások könnyebben integrálhatók. Hátránya viszont, hogy sok a duplum, amit szürni kell, és a rekordokat minőségi ellenőrzésnek kell alávetni. ${ }^{2}$

A VuFind egy nyílt forráskódú könyvtári információs portál, amelyet a Villanova Egyetem fejlesztett ki 2007-ben PHP programozási nyelven. Adatbázisként MySQL-t vagy PostgreSQL-t használ, a keresés indexeléséhez Solr ${ }^{3}$ eszközt alkalmaz. ${ }^{4}$

Az ELTE Egyetemi Könyvtár a VuFind rendszer implementálása mellett döntött. A jelenlegi fejlesztési fázisban a kollégákat bevonva belső tesztelést végzünk, és a tervek szerint 2017-ben tesszük elérhetővé az Egyetemi Könyvtári

${ }^{1}$ O'Reilly, Tim: What Is Web 2.0? Design Patterns and Business Models for the Next Generation of Software. Forrás: http://www.oreilly.com/pub/a/web2/archive/what-is-web-20.html (2016. szeptember 10.)

${ }^{2}$ Wilson, Katie: OPAC 2.0: Next generation online library catalogues ride the Web 2.0 wave! = Online Currents, 21. vol . 2007. 10. no. 406-413. p. Forrás: http://epubs.scu.edu.au/lib_pubs/11 (2016. augusztus 25.)

${ }^{3}$ A Solr nyílt forráskódú keresőplatform, mely Java programozási nyelven íródott. Forrás: http://lucene.apache.org/solr (2016. augusztus 22.)

${ }^{4}$ Ismertetés: https://vufind.org/vufind (2016. augusztus 22.) 
Szolgálat (EKSZ) megújult portálján keresztül, kezdetben nyilvános tesztelés céljából. Az esetlegesen felmerülő problémák javítása folyamatosan történik, a tervezett fejlesztéseket pedig müködés közben valósítjuk meg.

\section{Miért a VuFind?}

A VuFind mellett két fizetős szolgáltatást is teszteltünk, az EBSCO Discovery Service-t (EDS) és a Summont (Serials Solutions).

A nyílt forráskódú rendszerekkel már vannak pozitív tapasztalataink, hiszen az intézményi repozitóriumunknak, az ELTE Digitális Intézményi Tudástárnak (EDIT) is egy nyílt forráskódú szoftver, a DSpace ${ }^{5}$ az alapja, ezért bizakodva próbáltuk ki. A VuFind jól kombinálható a fizetős komplex keresőkkel, az EDS-t a tesztelési időszakra sikerrel implementáltuk a VuFindba. A VuFind lehetővé teszi a különböző metaadatformátumok helyi és külső források találatainak együttes elérését. A választás mellett szólt az is, hogy nagy a felhasználó könyvtárak száma, melyek között hazai példák is vannak, például a Debreceni Egyetem Egyetemi és Nemzeti Könyvtár (DEENK) és az Országos Széchényi Könyvtár (OSZK). Fontos számunkra továbbá, hogy a szoftver igényeink szerint alakítható, reszponzív, a legkülönfélébb eszközökön is optimális megjelenésü legyen. A keresést, böngészést az OAI-PMH (Open Archives Initiative Protocol for Metadata Harvesting) protokoll használatával learatott rekordok közös Solr adatbázisba való betöltése teszi lehetővé.

\section{A VuFind az ELTE-n}

Amikor elkezdtünk a VuFinddal dolgozni, nem gondoltuk, hogy az egyik legnagyobb kihívást a kereső elnevezése fogja jelenteni.

A könyvtáros szakmában tapasztalt változásoknak köszönhetően az utóbbi időben jelentősen bővült fogalmi készletünk. A nemzetközi szakirodalomból átvett kifejezésekre több fordítási kísérlet is születik, illetve előfordul, hogy az idegen elnevezés is elfogadottá válik. Az újgenerációs OPAC-okat hívhatjuk komplex adatbázis-keresőknek, discovery eszközöknek, vagy épp használhatjuk a discovery tools kifejezést. Mindemellett az általunk kialakított, személyre szabott rendszernek szeretnénk egy rövid, de kifejezö, az olvasók számára is érthető és elfogadott nevet adni. Az általunk jelenleg alkalmazott ELTE EKSZ metakereső elnevezés terveink szerint nem a végleges név, tehát tekinthető egyfajta munkacímnek, mely nagy valószínüség szerint a közeljövőben változni fog. Maga a VuFind rendszer elnevezése a fejlesztő Villanova University kezdőbetüiből és az angol find ('talál, megtalál') szóból született. Néhány külföldi felhasználó ezt a mintát követve nevezte el saját implementációját, például a Technische

${ }^{5}$ A DSpace közösség által fejlesztett nyílt forráskódú adattár alkalmazás, melyet a DuraSpace támogat. 
Universität Darmstadt TUFind névre, a Technische Hochschule Mittelhessen pedig THMFindra keresztelte keresőjét.

Jelenleg tehát az ELTE EKSZ metakereső néven futó ELTE-s VuFind - vagy, ha úgy tetszik, ELTEFind - fejlesztésén, testreszabásán dolgozunk. A kezdőoldal (1. ábra) megjelenésén nem sokat változtattunk, így a négy egységre - fejléc, keresősáv, böngészési lehetőségek, egyéb keresési, böngészési lehetőségek mellett segítséget nyújtó menüpontok - való tagolás is változatlanul maradt.

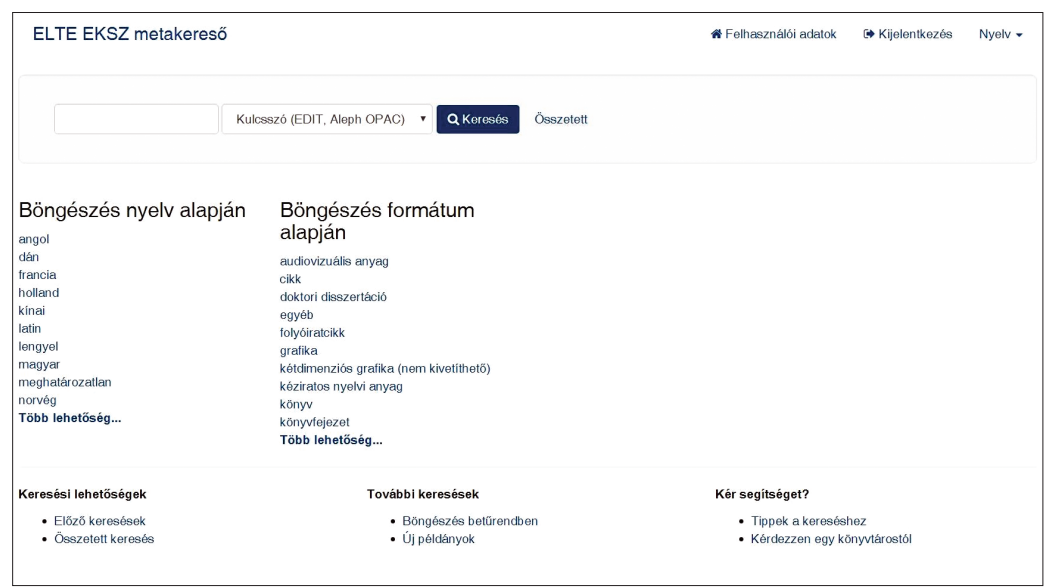

1. ábra. A VuFind kezdőoldala

Az egyszerú és az összetett keresés mellett nyelv és formátum szerinti böngészésre is van lehetőség. Megtekinthetők az előző keresések, az új példányok, vagy böngészhetünk betürendben. Beépített súgó is rendelkezésre áll Tippek a kereséshez elnevezés alatt, továbbá elérhető a Kérdezzen egy könyvtárostól funkció is, amellyel az Egyetemi Könyvtárinfo@lib.elte.hu e-mail címére lehet kérdést küldeni. Kinézetben az egyszerüségre és átláthatóságra törekszünk, igyekszünk a lehető legjobban kihasználni a rendszer adta lehetőségeket.

\section{A VuFind föbb jellemzői}

Az elavult keresési technológiák kiváltására létrejött, Google által inspirált discovery eszközök mind hasonló jellemzőkkel rendelkeznek, így a VuFind sem kivétel ez alól. A rendszer lehetővé teszi a felhasználó számára, hogy keressen egy alap keresőmezőben, majd a találati halmazt úgynevezett facetták segítségével szúkítse. Intézmény, formátum, szerző, nyelv és megjelenés éve szerint finomítható a keresés, de konfigurálható, egyéni igényekre szabható. A találati halmazban sárga háttérszínnel jelennek meg a keresési kifejezésnek megfelelő szavak. Az alábbi képen (2. ábra) egyszerü keresést végeztünk Arany Jánosra, majd a találati halmazt szerző szerint szükítettük (William Shakespeare). 


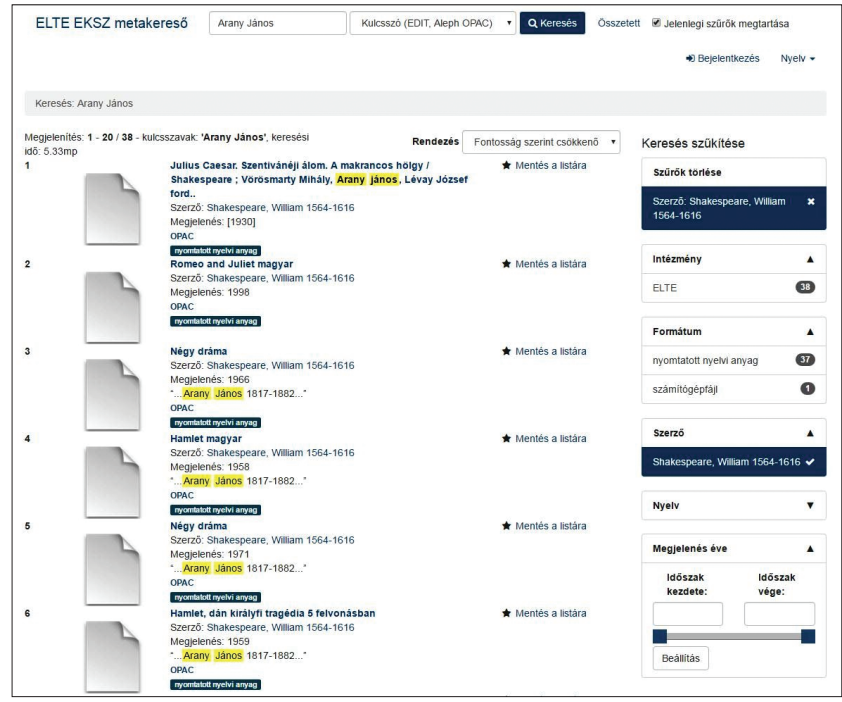

2. ábra. Keresés szükítés facetták segítségével

A találati oldalon a föbb és részletes adatok mellett meg tudja jeleníteni a rekord aktuális példánystátuszát, helyét. Az alábbi képen (3. ábra) egy tétel/rekord úgynevezett teljes nézetét látjuk. Amikor megtekintünk egy tételt, a rendszer a hasonló tételek listázásával javaslatokat ad további böngészéshez. A hasonló tételek két helyen is megjelennek, egyrészt - az asztali felületet használva - jobb oldalon listaszerüen, másrészt az alsó menüpontoknál - ahol a tételhez kapcsolódó információkat találjuk - indexképekkel.

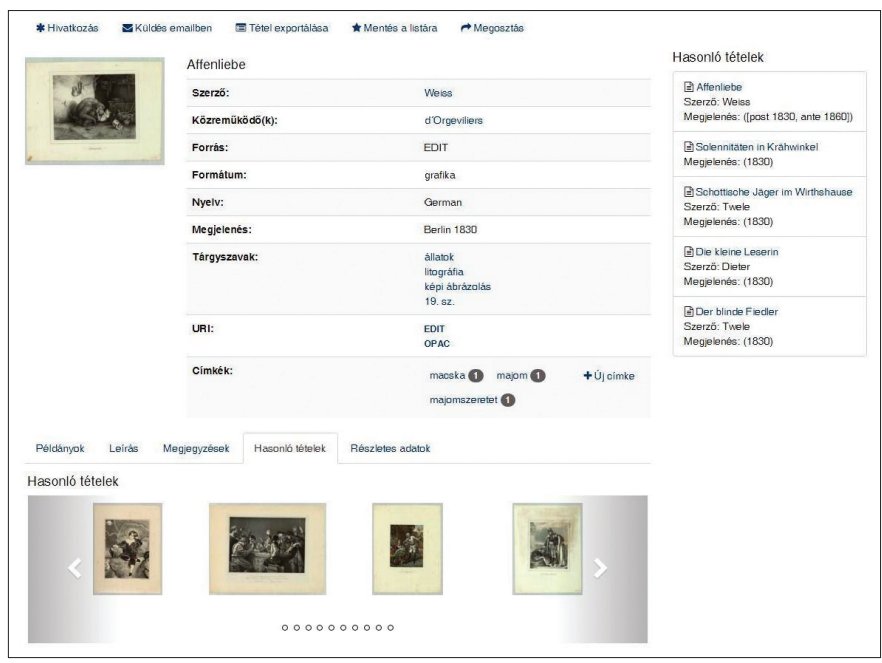

3. ábra. Tétel teljes nézete 
A tételeket saját listákba rendezhetjük a kis csillag mellett látható Mentés a listára hiperhivatkozásra kattintva, melyre mind a találati oldalon, mind a rekordnézet oldalon lehetőség van. A listára mentés alkalmával címkéket és megjegyzéseket is hozzáfüzhetünk a tételekhez (4. ábra). A listák folyamatosan bővíthetők, módosíthatók, illetve törölhetők, használatával elkerülhető például a hivatkozáskezelő szoftverek bizonyos funkcióinak alkalmazása, amelyek sok felhasználó számára túl bonyolultak, kényelmetlenek.

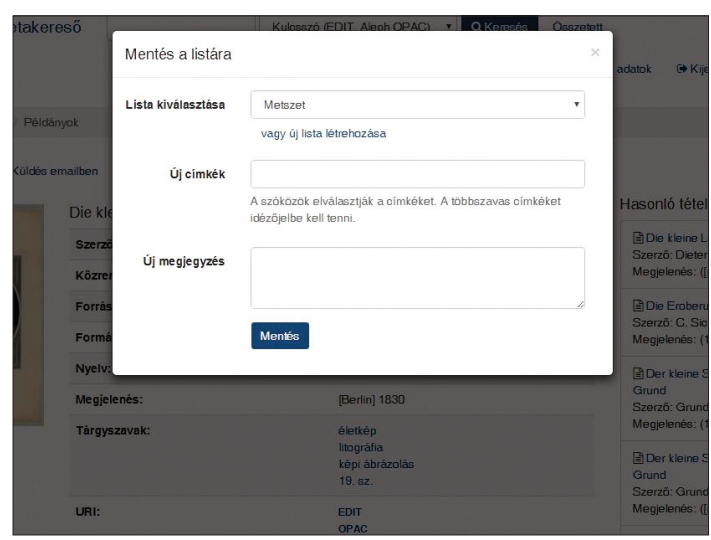

4. ábra. Tétel listába mentése

Az alábbi képen (5. ábra) egy olyan tétel látható, amely egy Metszet nevü listába van mentve. A rekord teljes nézeténél megjelenik a mentés helye, vagyis a lista neve, melyre kattintva az Elmentett példányokhoz irányít. A listákat itt szerkeszthetjük, törölhetünk belőlük számunkra feleslegessé vált tételeket, exportálhatjuk, nyomtathatjuk a lista egészét vagy egy részét (6. ábra).

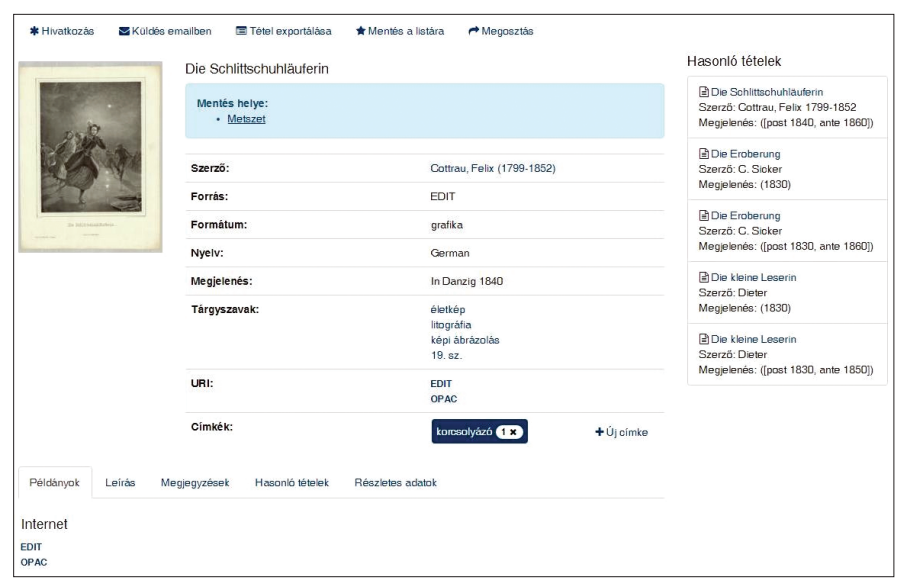

5. ábra. Tétel a listában 


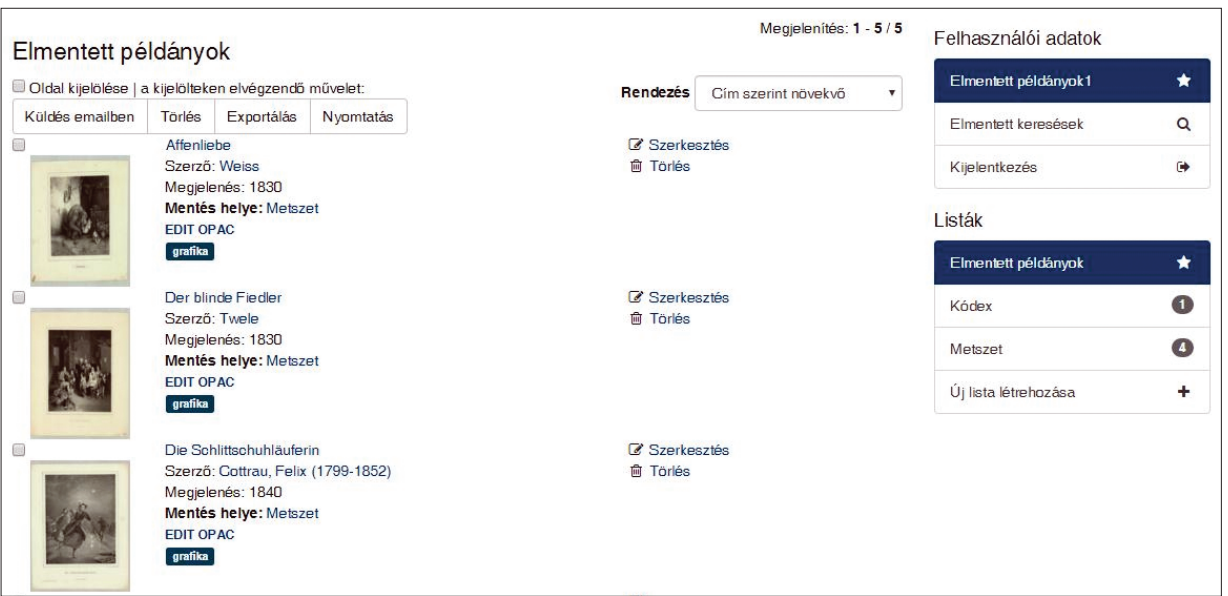

6. ábra. Elmentett példányok

A keresés mellett többféle szempont szerinti böngészésre is van lehetőség. A föoldalról indulva nyelv vagy formátum szerint tudunk böngészni, a betürendes böngészésnél választhatunk, hogy témakör, szerző vagy cím szerint szeretnénk áttanulmányozni a kínálatot (7. ábra).

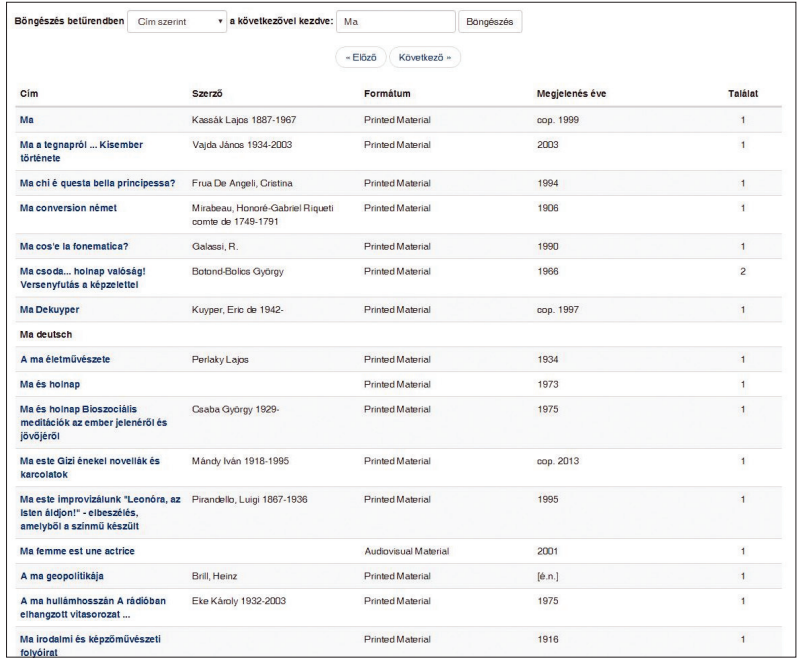

7. ábra. Böngészés cím szerint

Lehetőség van az újonnan betöltött példányok megtekintésére is. Kilistázhatjuk az előző napon, az előző 5 napon, illetve az előző 30 napon betöltött rekordokat (8. ábra). A kapott listát rendezhetjük relevancia vagy dátum szerint, illetve szükíthetjük a facetták segítségével. 


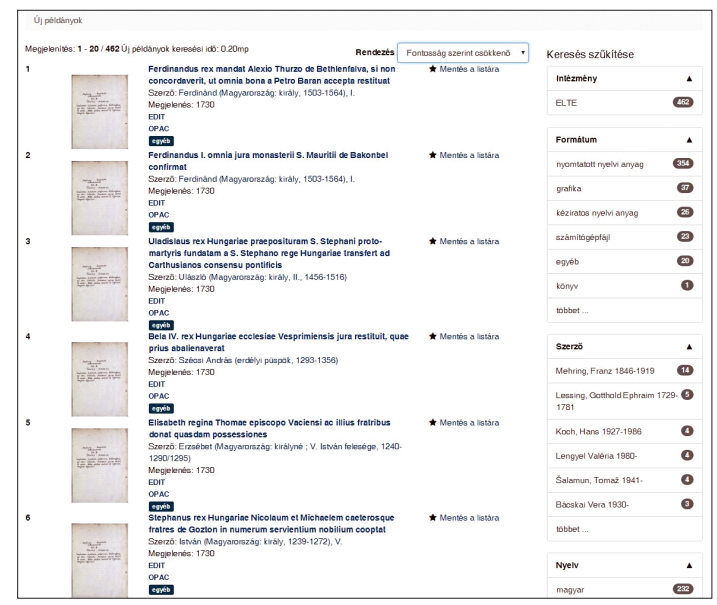

8. ábra. Új példányok böngészése

A tételeket, attól függetlenül, hogy saját listára mentettük vagy sem, megjegyzésekkel és címkékkel láthatjuk el (9. ábra). Természetesen ehhez és a listakészítéshez is regisztráció és bejelentkezés szükséges. Címkéinket, megjegyzéseinket bármikor törölhetjük, módosíthatjuk, a más felhasználó által felvetteket azonban nem szerkeszthetjük; a rendszer adminisztrátorának van lehetősége a hibás, oda nem illő címkék javítására, törlésére.

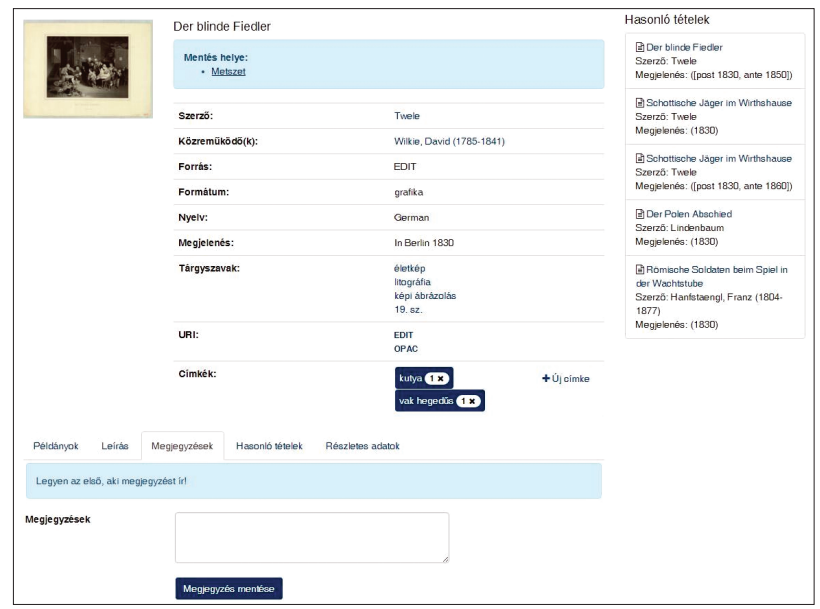

9. ábra. Címkék és megjegyzés hozzáfüzése

A rekord teljes nézeténél a szerző nevére kattintva további információkat tudhatunk meg az adott személyről, például a további műveinek kilistázása mellett a Wikipedia által biztosított életrajzi adatokat is megtekinthetjük (10. ábra). 


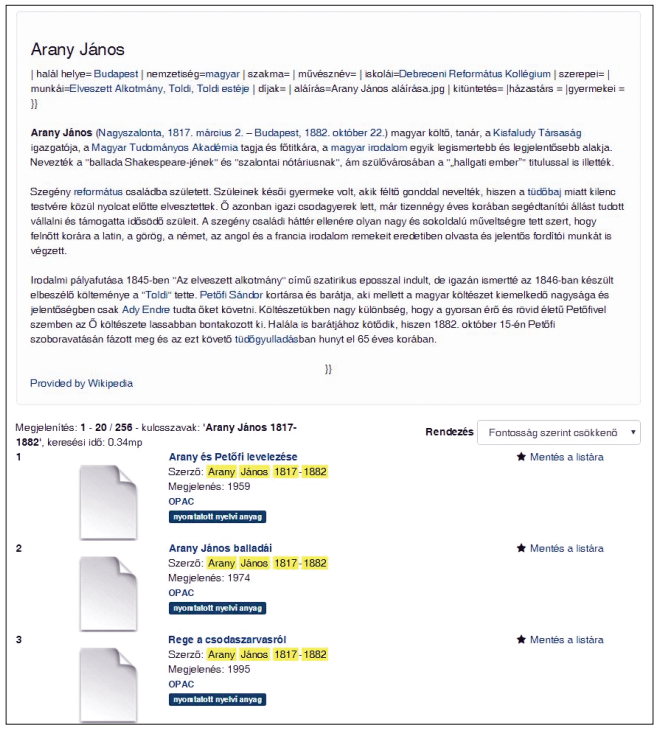

10. ábra. Wikipedia szócikk

A perzisztens, állandó URL-ek lehetőséget adnak a felhasználónak arra, hogy kereséseit vagy rekordjait megjelölje (könyvjelzőzze), így biztosítva a korábban meglátogatott oldalak könnyü visszakeresését. Az olvasó elmentheti vagy felcímkézheti a rekordokat a Zotero hivatkozáskezelö szoftverrel, így egy helyen tárolhatja azokat.

A VuFind számtalan nyelven elérhetö, saját fordítások is könnyen készíthetők. Sőt, amennyiben szeretnénk megváltoztatni a meglévő nyelvnél használt megfogalmazást, azt is megtehetjük.

A kereséshez, az adatok eléréséhez és számos egyéb funkció kihasználásához a rendszer többféle lehetőséget kínál. Egyidőben megoszthatjuk rekordjainkat más intézményekkel OAI szerveren keresztül, VuFind algoritmusokkal kereshetünk az Open Search által, és amennyiben teljes hozzáférést szeretnénk az indexelt adatokhoz, használhatjuk a beépített kereső és indexelő motorját, a Solr-t. ${ }^{6}$

\section{További beállítások, fejlesztések}

A VuFind számos hasznos, és a felhasználók által kedvelt funkciót tartalmaz, azonban adódtak olyan jellemzők, melyekre nem, vagy csak részben volt szükségünk, illetve néhány esetben indokoltnak tünt egy-egy kisebb átalakítás elvégzése.

A rendszert az egyéni igényeink szerint, a különböző elvárásoknak megfelelöen alakítjuk, s ennek révén a nyilvánosan elérhető csomagból hiányzó magyar fordítást a számunkra szükséges mértékben pótoltuk. A teljes, vagy más szóval

\footnotetext{
${ }^{6}$ VuFind. Forrás: https://vufind.org/vufind (2016. augusztus 22.)
} 
rekordnézeten is több változtatást végeztünk: nagyméretü képet illesztettünk be, a főbb adatok alatt lévő Hasonló tételek fülnél egységes méretü képeket jelenítünk meg, beillesztettünk forrásra (EDIT, OPAC) mutató URL-eket is. A teljes nézet felső menüsorában Megosztás menüpontot helyeztünk el (11. ábra), a Leirás fülről a főbb adatok közé helyeztük át a fizikai leírást.

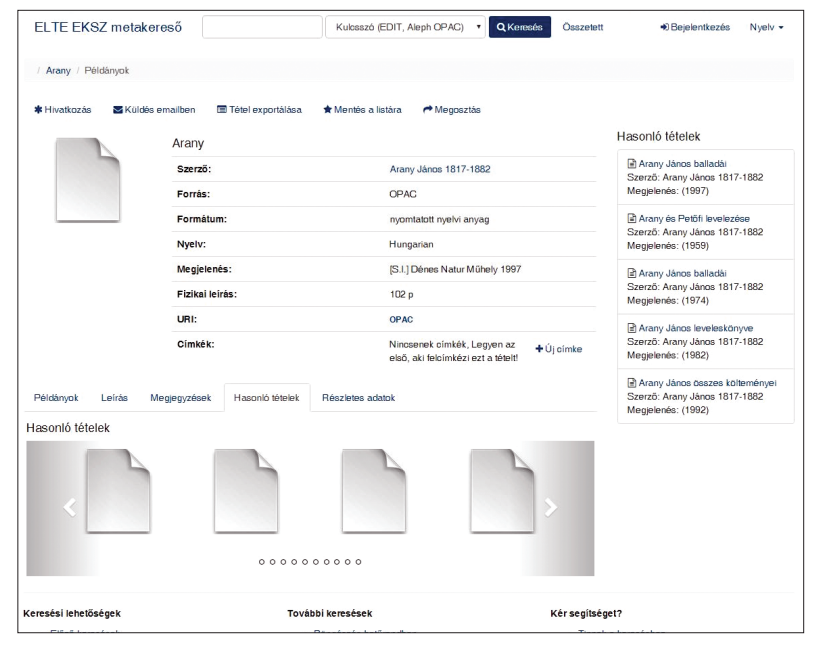

11. ábra. Hasonló tételek

Az integrált könyvtári rendszerből áttöltött kötetrekordok Kapcsolódó példányok mezőibe beillesztettük a fejrekordra mutató linket, a fejrekordba pedig a kötetrekordra mutató linket.

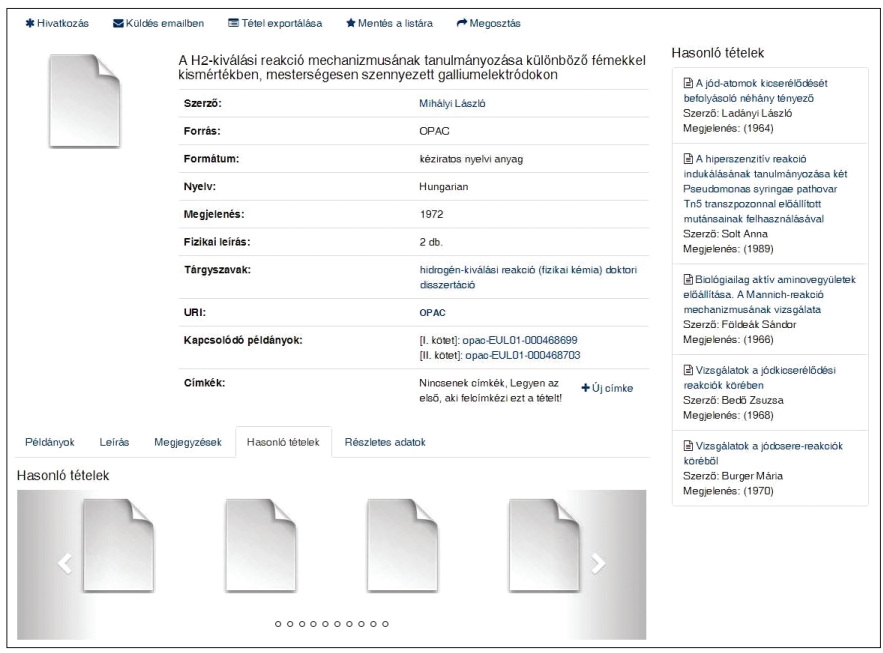

12. ábra. Kapcsolódó példányok 
A listákat vagy tételeket e-mailben továbbíthatjuk, az SMS küldési lehetöséget azonban megfelelő szerver hiányában letiltottuk. Ugyanakkor az alapértelmezetten letiltott BibTex és RIS export formátumok használatát engedélyeztük. Emellett a kiválasztott tételeket, vagy akár teljes listákat exportálhatjuk még Refworks, EndNote vagy EndNoteWeb bibliográfiakezelő rendszerekbe (13. ábra).

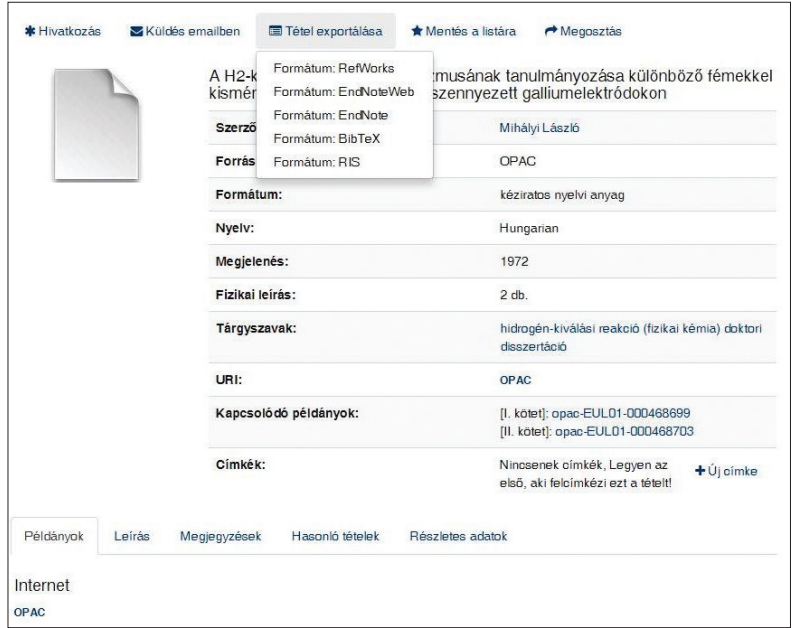

13. ábra. Tétel exportálása

Bejelentkezésnél http-ről a biztonságosabb https protokollra váltunk, valamint reCaptcha-t (14. ábra) használunk a scripttel történő, tömeges felhasználói regisztrációk megakadályozására.

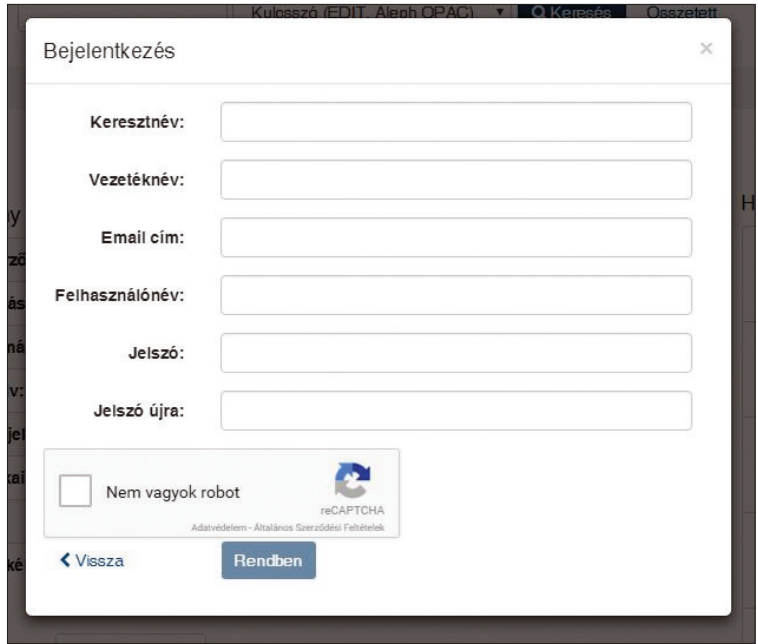

14. ábra. reCaptcha a bejelentkezésnél 
A VuFind lehetőséget biztosít a felhasználói regisztráció, ill. bejelentkezés letiltására is, de ezzel elvész a kereső közösségi használatának lehetősége. A bejelentkezett felhasználók által végezhető funkciók (úgymint a címkézés, megjegyzés hozzáfüzése, keresési kulcsszavak vagy tételek mentése) külön engedélyezhetők/letilthatók, de erre csak globálisan, az összes felhasználóra vonatkozóan van lehetőség.

\section{Hogyan tovább?}

A rendszer kialakításánál fokozottan figyelünk az egyenlő esélyü hozzáférés biztosítására, maradéktalanul figyelembe vesszük a webes akadálymentesség nemzetközi szintü hivatalos ISO/IEC 40500:2012 szabványát. A belső, azaz az ELTE Egyetemi Könyvtáron belüli, majd nyilvános tesztelés eredményeinek értékelése után elvégezzük a szükséges javításokat. A későbbiekben szeretnénk előjegyzési funkciót beállítani. Dolgozunk a nyelvek megnevezésének fordításán a nyelvre való szürésnél, a formátum megnevezések fordításán a formátum szürőnél, illetve a sorozatcím megjelenítésén az OPAC-os rekordoknál.

A VuFind a különféle adatbázisokat elérhetővé tevő moduljait drivereknek nevezi. A Web of Knowledge driver jelenleg fejlesztés alatt van (Web of Science). Részt veszünk a Science Direct API (Application Programming Interface) programjában, mely lehetöséget ad arra, hogy nyílt hozzáférésü tartalmai között is kereshessünk. Továbbá tervezzük többek között a Scopus kereső elérésének megvalósítását. A későbbiekben a duplumszürésre is nagyobb hangsúlyt fektetünk.

A felmerülő problémák folyamatos javítása is hozzájárul ahhoz, hogy valódi újgenerációs discovery szolgáltatást tudjunk nyújtani felhasználóinknak.

\section{Rezümé}

A webes alkalmazásokhoz szokott olvasóra frusztrálóan hathat egy kényelmetlen, elavult könyvtári katalógus, nem beszélve arról, hogy több adatbázisban, katalógusban kell keresnie ahhoz, hogy információhoz jusson. A közös keresők, discovery eszközök használatával a könyvtárak egypontos keresőfelületet biztosíthatnak a felhasználóknak, csökkentve ezzel a kereséssel töltött időt. A VuFind nyílt forráskódú könyvtári kereső alkalmazásával egy felületen kereshető az ELTE Egyetemi Könyvtári Szolgálat könyvtári katalógusa és az EDIT (ELTE Digitális Intézményi Tudástár), valamint előfizetett adatbázisok szolgáltatására is alkalmas. Az igényeink szerint alakítható, reszponzív, relevancia-alapú keresővel, szürési lehetőségekkel, webkettes funkciókkal igazi újgenerációs katalógust nyújthatunk a használóknak már az ELTE-n is. 


\section{OPAC 2.0 at ELTE}

\section{VuFind, the Web 2.0 Technology Based Library Search Engine}

For readers who are used to web applications, it can be frustrating to use outdated library catalogues, not to mention that they need to search in multiple databases and catalogues in order to find information. With the use of connected search engines and discovery tools, libraries can provide one box search interface for their users, reducing the amount of time they have to spend with searching. With the use of the open-source library search tool called VuFind the catalogue of the ELTE University Library Services and EDIT (ELTE Digital Institutional Repository) can be searched on the same interface having an opportunity to use subscription based databases at the same time. From now on we can provide a next generation catalogue for users at ELTE that is responsive, can be modified on demand, has relevance based search, filtering options and web 2.0 functions.

VIRÁG GABRIELLA

EDIT központi adminisztrátor

ELTE Eötvös Loránd Tudományegyetem Egyetemi Könyvtár ORCID: 0000-0002-3942-5212 


\section{Kötetünk szerzői*}

Börzsönyi Nóra: Budapesti Corvinus Egyetem Egyetemi Könyvtár, informatikus könyvtáros.

Elérhetőség: nora.borzsonyi@uni-corvinus.hu.

Czinki-Vietorisz Gabriella: ELTE Egyetemi Könyvtár, informatikus könyvtáros. Elérhetőség: vietorisz.gabriella@lib.elte.hu.

Cséka György: ELTE Egyetemi Könyvtár, osztályvezető.

Elérhetőség: cseka.gyorgy@lib.elte.hu.

Csuk Csaba: Nyugat-magyarországi Egyetem Savaria Egyetemi Központ Könyvtár és Levéltár, könyvtárigazgató-helyettes.

Elérhetőség: csuk.csaba@sek.elte.hu.

Domokos György: PPKE BTK Olasz Tanszék, egyetemi docens.

Elérhetőség: domokos.gyorgy@btk.ppke.hu.

Garamvölgyi László: ELTE Egyetemi Könyvtár, informatikus könyvtáros.

Elérhetőség: garamvolgyi.laszlo@lib.elte.hu.

Gyuricza Andrea: MTA Könyvtár és Információs Központ, fiatal kutató.

Elérhetőség: gyuricza.andrea@konyvtar.mta.hu.

Haász Antal: MTA Könyvtár és Információs Központ, osztályvezető-helyettes.

Elérhetőség: haasz.antal@konyvtar.mta.hu.

Kálóczi Katalin: ELTE Egyetemi Könyvtár, föigazgató.

Elérhetőség: foigazgato@lib.elte.hu.

Kiszl Péter: ELTE BTK Könyvtár- és Információtudományi Intézet, intézetigazgató egyetemi docens.

Elérhetőség: kiszl.peter@btk.elte.hu.

Knapp Éva: ELTE Egyetemi Könyvtár, főtanácsos, tudományos ügyek referense.

Elérhetőség: knapp.eva@lib.elte.hu.

Mátyás Melinda: ELTE Egyetemi Könyvtár, informatikus könyvtáros.

Elérhetőség: matyas.melinda@lib.elte.hu.

* 2017. február 1-je óta a Nyugat-magyarországi Egyetem Savaria Egyetemi Központ Könyvtár és Levéltár ELTE Egyetemi Könyvtár és Levéltár Savaria Egyetemi Könyvtár és Levéltár, az ELTE Egyetemi Könyvtár ELTE Egyetemi Könyvtár és Levéltár néven müködik tovább. 
Naszádos Edit: MTA Könyvtár és Információs Központ, szakmai tanácsadó.

Elérhetőség: naszados.edit@konyvtar.mta.hu.

Szalay Péter: ELTE, tudományos ügyek rektorhelyettese.

Elérhetőség: tudrh@elte.hu.

Tüskés Anna: MTA BTK Irodalomtudományi Intézet, tudományos munkatárs.

Elérhetőség: tuskes.anna@btk.mta.hu.

Virág Gabriella: ELTE Egyetemi Könyvtár, informatikus könyvtáros.

Elérhetőség: virag.gabriella@lib.elte.hu. 

Kiadta az ELTE Egyetemi Könyvtár és Levéltár Felelős kiadó: Kálóczi Katalin főigazgató Cím: 1053 Budapest, Ferenciek tere 6.

Borítóterv: Hajtmanszki Péter Műszaki szerkesztő: Szabó Panna A kötet elkészítésében közremüködött: Acsai János 